

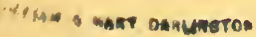

$$
\begin{aligned}
& \text { of munite seventers } \\
& \text { t "If }
\end{aligned}
$$

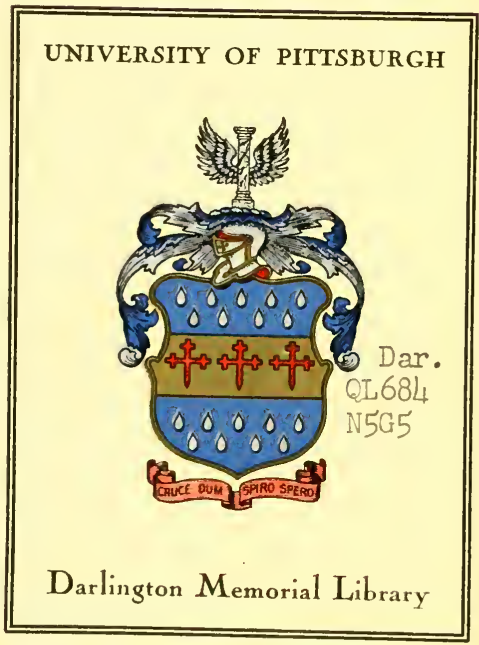








\section{BIRDS OF LONG ISLAND.}

BY J.P. GIRAUD, JR.,

MEMBER OF THE LYCEUM OF NATURAL HISTORY, NEW-YORK, CORRESTONDING MEMBER OF THE ACADEMY OF NATURAL SCIENCES, PHILADELPHIA, \&C.

NEW-YORK :

PUBLISHED BY WILEY \& PUTNAM, 161 BROADWAY. Tobitt's Print, 9 spruce st. 
[Entered according to Act of Congress, in the year 1843, by J. P. GIRAUD, Jr., in the office of the Clerk of the Southern District of New York.] 


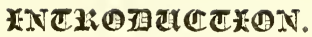

The great expense attending works embellished with costly engravings, as well as the strictly scientific character of most works treating of Natural History, limits such subjects comparatively to the few. Frequent complaints of this nature have induced me to offer the present volume, with a view of placing within the reach of the "gunners," the means of becoming more thoroughly acquainted with the birds frequenting Long Island.

The additions all departments of Natural History are continually receiving, is evidence, that with however much zeal and energy the different branches have been pursued, and notwithstanding the praiseworthy exertions bestowed by those who have distinguished themselves in their various pursuits, still we find their labors are not so far complete as to leave nothing for their successors.

While the Botanist, Mineralogist, Entomologist, and Conchologist are enriching their cabinets, the Ornithologist is finding in our vast territory undescribed species. The "Journal of the Academy of Natural Sciences, Philadelphia," (1841,) contains an article giving the views of Dr. Bachman, relative to the course our Naturalists should pursue in the publication of American species viz. "that all north of the Tropic of Cancer twenty-three and a half degrees, should be called North America-the Tropics, Tropical or Central America-and south of the Tropic of Capricorn, South America." The large scope which our Zoology embraces, deters many persons from making collections, as they despair ever being able to complete them. I would therefore suggest to amateurs the propriety of commencing with a view of collecting such species as are to be found in their own district, taking the State or even 
the County in which they reside; pursuing this plan, they would be enabled to obtain such species of birds as visit their section, and also have an opportunity of studying their habits, which affords greater pleasure than labelling a dried skin, received from a distance. In this way I have no doubt that many interesting facts would be acquired relative to the migration and habits of many species of which at present we know but little; and it is highly probable that new species would be discovered even in those sections supposed to be thoroughly explored, leaving the remote regions to the taste and liberality of travellers, or to some adventurous spirit like Townsend, who enriched our Ornithology by disco. veries made during his journey across the Rocky Mountains, and along the shores of the Columbia River.

The occurrence on Long Island of many species that are rarely or never observed in other parts of the middle districts, will doubtless appear somewhat remarkable to those who are unacquainted with the locality; but when they examine the map, and find that his lengthy and comparatively narrow Island extends some distance into the ocean nearly at right angles with the southern portion of the coast of the United States, comprising within its boundaries numerous bays, inlets, shoals, and bars, abounding with all the varieties of food peculiar to almost every species of marine birds, it will not seem surprising that those species which are more abundant in the higher as well as the more temperate latitudes, should, in their wanderings, visit these hospitable shores.Not only is our section the resort for nearly every species of Water Bird found within the limits of the United States, but out of more than five hundred birds now ascertained to belong to North America, two hundred and eighty-six have been known to visit this far-famed Island. Indeed, no portion of our country, of the same extent, is richer in resources for the student of Natural 
History, or more inviting to the sportsman, than this garden of the middle districts. Its Great South Bay, "occupying a distance of seventy miles' uninterrupted inland navigation," with its sea-washed shores, abounding with numerous species of shell and other fish, doubtless contains treasure unknown to the Ichthyologist and Conchologist. Its variety of soil affords an excellent field to the Botanist, and its alluvial formations furnish much that is interesting to those pursuing the grand and comprehensive science of Geology. The frequent occurrence of those beautiful streams for which the Island is so justly celebrated, excites the admiration of the Angler; and the noble Buck roams proudly through its forests. Often when examining the shell banks, (the lndian's mint) found on the margins of many creeks, in search of some relic of by-gone days, have I wandered back into the past, and readily imagined that the primitive inhabitants have on this productive Is. land enjoyed all that is pictured in the red man's happiest dream of paradise. A few half-breeds still cling to the soil of their ancestors; but the next generation will have to refer to the pages of history to point out where dwelt the once-powerful race of Montauks, and other tribes that have dwindled away before the rapid strides of civilization.

Before describing the "Birds of Long Island," I will here remark, that the difference in plumage and other characteristics, does not arise from their indiscriminately mating, as supposed by some. This cannot be; if it were, every season would produce such endless varieties, that any attempt at classification would prove abortive. On the contrary, we see year after year the same broad characters which determine the Genera, with the specific markings denoting the species; and at this late period, a new species discovered east of the Mississippi, is of rare oc currence. 
It is the opinion of the writer, that those who pass through life without stopping to admire the beauty, organization, melody, or habits of Birds, rob themselves of a very great share of the pleasures of existence. In spring; when Nature has recovered from the chilling blasts of winter, and again puts forth her rich foliage, what can be more delightful than to listen to the rich melody of cur songsters, robed in their nuptial plumage, perched on the branch of the rich magnolia, arranging their splendid attire with studied care, as if jealous that the swelling buds would put forth blossoms that would rival them in beauty? Joyous indeed is it to watch the gay Humming Bird sporting around the fragrant honeysuckle, fearless of man, as if conscious of its innocence-little knowing that its small but brilliant body is more highly prized by him than the cumbrous form of the Vulture, here sipping the dew-drops made fragrant through the agency of the rose-there probing the peony to extract its insect prey, or hovering round the closed bud of the lily, impatiently waiting for the unfolding of its swelling leaflets, to revel in its luxuriance?

The Water Birds, though not possessed of the bright plumage and sweetly-toned voice of the gaily-attired minstrels confined to the land, have their charms. Pleasing is it when invited by the invigorating breeze, to visit the sea-shore-or perchance, when rambling along the borders of our great lakes, to mark how beautifully the providence of Nature is developed in the well-adapted forms to the habits of the "Water Fowl," and also to observe the regular order in which large flocks move when hastening, at the approach of winter, to a more genial clime-from whence, in early spring, they return to the "great nursery" at the North. It is also interesting to notice the various shades of plumage, from the gay Summer Duck to the sombre Surf Duck, each tinge, spot, and line showing superior intelligence; but in this, like all other parts of Creation, man, with his boasted knowledge, knows nothing of first causes. 
Some species frequent the still ponds and shady creeks; others pass their time at sea; while many crowd our bays and harbors, con. tributing to our support. Some feed on shelly molusca; others subsist chiefly on vegetables; and many regale themselves on finned prey.

The great changes which birds undergo until they arrive at full and mature plumage, as well as the various changes the adults are subjected to from Spring to Autumn, teaches us that plumage is not at all times the best criterion for specific characters. Therefore the writer would urge the importance of paying attention to the bills, tarsi and feet, which, with the habits and notes, are certain characters.

The plumage first engages the attention of the student. This should be examined during Spring, when most of our birds appear in full and decided dress, and the notes of all our Song Birds are frequent and clearly expressed. The next is their habits, which, in some cases the peculiarities are so difficult to describe, that in a written description of closely-allied species, there may appear but a trifling difference; yet to a close observer, the manners and customs peculiar to certain species, the mode of building their nests, their eggs, \&c., are sufficient of themselves to form distinctive characters. In Autumn, when those which have passed on to other districts to breed, return with their young, in whatever liverv they may then appear, the species may be determined to a certainty by recognizing its peculiar note; which, in but very few instances, can be intelligibly communicated by syllables. In other words, the place to study Ornithology is in the open air, while rambling through the woods and fields, following the water-courses; and by frequenting the sea-shore and interior lakes-thus studying from Nature, the best of all preceptors. With those species which are of exceedingly rare occurrence, and the habits of which you have had no opportunity of observing, or tracing the plumage in its different stages, the formation of the bills, tarsi, feet, and toes, will assist in defining closely-allied species. 
Those closet Naturalists, who study altogether from dried specimens, are merely theorists. Such a course may serve to amuse the student who is content with acquiring only the classification of this beautiful and highly interesting part of the animal creation, of the habits and abode of which, he knows nothing practically; to such, the poetry of Ornithology is entirely lost.

The descriptions of plumage I have taken from a collection now before me, comprising; with but few exceptions, all those species figured by $\mathrm{Mr}$. Audubon in his great, and to our country, highly creditable work on the "Birds of America," the majority of the species having been procured by my own hand. Should I, from the plain manner in which I have endeavored to point out the specific characters of those procured on Long Island, as well as by placing within reach of those who are in daily use of the gun, a simple Book of Reference, be instrumental in adding to our already large Fauna, or acquire a further knowledge of the habits of those species which with us are but little known, the purpose of the writer will be accomplished.

In preparing a list of the Birds of Long Island, I have studiously avoided introducing any species that I have not met with, or received from the very best authority an intimation of its occurrence in our locality. In-speaking of the migrations and habits of species for which my opportunities for observation have been very limited, I have had recourse to the works of various authors, none of which have been more closely consulted than the highly instruc. tive pages of Wilson and Audubon. In comparing specimens in various stages of plumage, I have enjoyed the privilege of the valuable Cabinets of Messrs. Bell, Lawrence, and Brasher, who, from their Ornithological acquirements, as well as their acquaintance with the locality with which we are engaged, have contributed much valuable information. J. P. GIRAUD, $\mathrm{J}_{R}$.

New-York, June, 1843. 


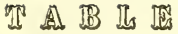

oF

FAMILY, GENERA, AND SPECIES OF THE BIRDS OF LONG ISLAND, (ARRANGED ACCORDING TO THE CLASSIFICATION OF AUDUBON.)

Cathartes aura

FAMILY VULTURINA.

VULTURINE BIRDS.

GENUS CATHARTES.

Turkey Vulture.

Turkey Vulture, or Turkey-buzzard

FAMILY FALCONINÆ.

FALCONINE BIRDS.

GENUS BUTEO.

Buzzard.

Buteo borealis

" Pennsylvanicus

" lagopus

" lineatus

Red-tailed Buzzard

Broad-winged "

Rough-legged “

Red-shouldered “"

GENUS AQUILA.

Eagle.

Aquila chrysaetos

Golden Eagle

GENUS HALIFTUS.

Sea Eagie.

Haliaetus leucocephalus

GENUS PANDION.

White-headed or Bald Eagle

Osprey.

Pandion haliaetus

GENUS NAUCLERUS.

Fish Hawk or Osprey

Swallow-tailed Hawk.

Nauclerus furcatus

Swallow-tailed Hawk

GENUS FALCO.

Falcon.

Falco peregrinus

" sparverius

" coluabarius

Peregrine Falcon

Sparrow "

Pigenn "

GENUS ASTUR.

Hawk.

Astur palumbarius

"f fuscus

" Cooporii

Gos Hawk

Sharp-shinned Hawk

Cooper's 
GENUS CIRCUS.

Harier.

Circus cyaneus

Common Harricr or Marsh Hawls

FAMILY STRIGIN王.

OWLS.

GENTS SLRNLA.

Day Owl.

Surnia nyctea

Srowy Owl

GENUS ULULA.

Night Owl.

Ulula acadica

Acadian Owl

GENUS SYRNIUMI.

Hooting Owl.

Syrnium nebulosa

Barred Owl

GENUS OTUS.

Eurcd-cul.

Otus vulgaris
"* biachyotos

Long-eared Owl

GENUS BUBO.

Short-eared .6

Horned oul.

Bubo Virginianus

Virginian Horned Ow]

Mottled Horned "

FAMILY CAPRIMULGINÆ.

GOAT-SUCKERS.

GENES CAPRIMULGU.

Goal-sucker.

Caprimulgus vociferus

Whip-poor-will

GENUS CHORDEILES.

Night Hauk.

Chordeiles Virginianus Night Hawk

FAMILY CYPSELINAE.

SWIFTS.

GENUS CHETURA.

Spine-tail.

Cbaetura pelasgia

Chimney Swallow or American Swifb

FAMILY HIRUNDIN Æ.

SWALLOWS.

GENUS HIRUNDO.

Swallow.

Hirundo purpurea

Purple Martin

Barn Swallow

" rustica

White-bellied Sivallow

“ bicolor

“ fulva

Bank

Cliff

66

66

FAMILY MUSCICAPINAE.

FLYCATCHERS.

GENUS MUSCICAPA.

Flycatcher.

Muscicapa tyrangua

“ acadica
Tyrant Flycatcher

Small Green-crested Flycatcher 
Muscicapa crinita

" fusca

“ virens

، pusilla

، ruticilla

Culicivora cœrulea

Great Crested Flycatcher

Pewee

Wood Pewee

Least Pewee

American Redstart "

GENUS CULICIVORA.

Gnal-catcher.

Blue-gray Gnat-catcher .

\section{FAMILY SYLVICOLINAE.}

WOOD WARBLERS.

GENUS MYIODIOCTES.

Myiodioctes mitratus

Flycatehing Warbler.

" Canadensis

" formosa

" Wilsonii

Sylvicola pinus

" discolor

" striata

" Blackburniæ

" maculosa

" coronata

“ Canadensis

" virens

" astiva

" petechia

" Americana

" maritima

" castanea

" icterocephala

Trichas Marylandica

" Philadelphia

Helinaia solitaria

“ vermivora

“ chrysoptera

" rubricapilla

Mniotilta varia

Hooded Flycatching Warbler Spotted Canadian " "

Kentucky

Wilson's

GENUS SYLVICOLA.

Wood Warbler.

Pine creeping Wood Warbler

Prairie

Black-poll

Blackburnian

$66 \quad 66$

Blue-headed Yellow-rumped

Yellow-crowned "

Black-throated Blue "

Black-throated Green "

Yellow-poll " " "

Yellow Red-poll " "

Blue Yellow-backed "

Cape May " " "

Bay-breasted " " "

Chestuut-sided " "

GENUS TRICHAS.

Ground Warbler.

Maryland Ground Warbler

Mourning

GENUS HELINAIA.

Swamp Warbler.

Blue-winged Yellow Swamp Warbler

Worm-eating

Golden-winged

Nashville

" " "

GENUS MNIOTILTA.
Creeping Warbler.

Black-and-white Creeping Warbler

\section{FAMILY CERTHINAE.}

CREEPERS.

GENUS CERTHIA.

Tree Creeper.

Certhia familiaris

Brown Tree Creeper

GENUS TROGLODYTES.

Wrens.

Troglodytes hy'emalis ædon

“ Americanus

Winter Wren

House "*

Wood 
$\begin{array}{cc}\text { Troglodytes Ludovicianus } & \text { Great Carolina Wren } \\ \text { palustris } & \text { Marsh }\end{array}$

FAMILY PARINAE.

TITS.

GENCS PARUS.

Tit.

Parus atricapillus " bicolor Black-capt Titmouse
Crested

FAMILY SYLVIANAE.

WARBLERS. GENUS REGULUS.

$\underset{\text { Regulus calendula }}{\text { satrapa }}$ Kinglet.
Ruby-crowned Kinglet
American Golden-crested Kinglet
GENUS SIALIA.
Blue Bird.
Common Blue Bird

Sialia Wilsonii
Orpheus polyglottus " Carolineusis ¿ rufus

Turdus migratorius

" mustelinus

" Vilsonii

" minor

" olivaceous

\section{FAMILY TURDINAE.}

THRUSHES.

GENUS ORPHEUS.

Mocking-bird.

Gray Mocking-bird.

Black-capped Mlocking-bird, or Thrush

Fermginous " " "

GENUS TLRDUS.

Thrushes.

Red-breasted or Migratory Thrush

Wood

Wilson's

Hermit

Olive-backed
66
66
66
66

\section{FAMILY MOTACILLINAE.}

WAGTAILS.

GENUS SEIURUS.

Woou-uaglails.

Seiurus aurocapillus

"Novæboracensis

Golden-crowned Wood-wagtail
Aqnatic

GENUS ANTHUS.

Pipit.

Anthus Ludovicianus

American Pipit

\section{FAMILY ALAUDINAE. \\ LARKS. \\ GENUS ALAUDA. \\ Lark.}

Alauda alpestris

Shore Lark
FAMILY FRINGILLINAE. FINCHES.

GENUS PLECTROPHANES.

Lark Bunting.

Plectrophanes nivalis

Lapponica
Snow Jark Bunting

Lapland Lark Bunting 
GENUS EMBERIZA.

Bunting.

$\begin{array}{cl}\text { Emberiza Americana } \\ \text { " } & \text { graminea } \\ \text { “ } & \text { savanna } \\ \text { " } & \text { passerina } \\ \text { " } & \text { Henslowii } \\ \text { " } & \text { posilla } \\ \text { " } & \text { Canadis } \\ & \end{array}$

Niphae hyemalis

Spiza cyanea
Black-throated Bunting

Bay-winged

Savannah

Yellow-winged

Henslow's

Field

Chipping

Canada
"

a

46

“

66

“

“

GENUS NIPHÆ.

Snow-bird.

GENUS SPIZA.

Painted Bunting.

Indigo Painted Bunting

GENUS AMMODRAMUS.

Shore Finch.

$$
\begin{gathered}
\text { Ammodramus maritimus } \\
\text { " }
\end{gathered}
$$
Gray Shore Finch
Buff-breasted
Marsh

GENUS LINARIA.

Linnet.

Linaria pinus
minor

Pine Linnet

Lesser Red-poll Linnet

GENUS CARDUELIS.

Goldfinch.

Carduelis tristis

GENUS FRINGILLA.

American Goldfinch

Finch.
Fringilla iliaca
" melodia
“Pennsylvanica
" leucophrys

GENUS PIPILO.

Fox-colored Finch

Song

White-throated "

White-crowned "

Ground Finch.

Pipilo erythrophthalmus

Towhe Ground Finch

GENUS ERYTHROSPIZA.

Purple Finch.

Erythrospiza purpurea

GENUS CORYTHUS.

Crested Purple Finch

Pine Finch.

Corythus enucleator

Common Pine Finch, Pine Grosbeak GENUS LOXIA.

Crossbill.

Loxia curvirostra

" leucoptera

GENUS PITYLUS.

Common Crossbill

White-winged "

Cardinal Grosbeak.

Pitylus cardinalis

Cardinal Grosbeak

GENUS COcсовоRUs.

Song Grosbeak.

Coccoborus Ludovicianus

Rose-breasted Grosbeak 
GENUS PYRANGA.

Tanager.

Pyranga rubra

Scarlet, Tanager

FAMILY AGELAIN瓜.

MARSH BLACKBIRDS.

GENUS DOLICHONYX.

Rice Bird.

Dolichonys oryzivora

Rice Bird

GENUS NOLOTHRUS.

Cou Bird.

Moluthrus pecoris

Cow.pen Bird

GENUS AGELAIUS.

Marsh Blackbird.

Agelaius phoeniceus Red-winged Starling or Marsh Blackbird GENUS ICTERUS.

Oriole.

Icterus Baltimore

" spurius

Baltimore Hang-nest or Oriolo
Orchard

GENUS QUISCALUS.

Crow Blackbird.

Quiscalus versicolor

" ferrugineus

Purple Grakle

Rusty

FAMILY STURNINE.

STARLINGS.

GENUS STURNELLA.

Meudow Starling.

Sturnella Ludoviciana

Crescent Meadow Starling

\section{FAMILY CORVINAE.}

CROWS.

GENUS CORVUS.

Crous.

Corrus corax

"Americanus

Garrulus cristatus

Raven

American Crow

GENUS GARRULUS.

Jay.

Blue Jay

FAMILY LANINAE.

SHRIKES.

GENUS LANIUS.

Shrikc.

Lanius borealis

Great Ameriran Shrike

FAMILY VIREONINAE.

GREENLETS.

GENUS VIREO.

Vireo olivaceus

"Novæboracensis

Greenlet.

Red-eyed Greenlet

White-eyed " 


$$
\begin{gathered}
\text { Vireo flavifrons } \\
\text { " solitarius } \\
\text { " gilvus }
\end{gathered}
$$

Icteria viridis
Yellow-throated Greenlet

Solitary

Warbling

\title{
FAMILY PIPRINAE.
}

MANAKINS.

GENUS ICTERIA.

Chat.

\author{
FAMILY AMPELINAE. \\ CHATTERERS. \\ GENUS BOIBYCILLA. \\ Waxwing. \\ Bombycilla Carolinensis
" garrula \\ Cedar Waxwing \\ Black-throated Waxwing \\ FAMILY SITTINAE. \\ NUTHATCHES. \\ GENUS SITTA. \\ Nuthatch. \\ Sitta Carolinensis \\ "Canadensis \\ White-breasted Nuthatch \\ Red-bellicd
}

\section{FAMILY TROCHILINAE. \\ HUMMING BIRDS. \\ GENUS TROCHILUS. \\ Humming-bird.}

Trochilus colubris

Ruby throated Humining Bird

\section{FAMILY ALCEDINAE. \\ KINGFISIERS. \\ GENUS ALCEDO. \\ King fisher.}

Alcedo alcyon

Belted Kingfisher

\author{
FAMILY PICINAE. \\ WOODPECKERS. \\ GENUS PICUS.
}

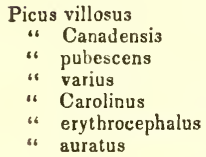

Woodpeclecr.

$\begin{array}{ll}\text { Hairy Woodpecker } & \text { "6 } \\ \text { Canadian } & \text { "6 } \\ \text { Downy } & \text { Yellow-bellied } \\ \text { Red-bellıed } & \text { "6 } \\ \text { Red-headed } & \text { "6 }\end{array}$

\section{FAMILY CUCULINA. \\ cUCKOOS. \\ GENUS COCCYZUS.}

Coccyzus Americanus

Cuckoo.

Biack-billed 


\title{
FAMILY COLUMBINAE.
}

PIGEONS.

GENUS ECTOPISTES.

Ectopistes migratoria

Carolinensis

Long-tailed Dove.

Wandering Long-tailed Dove

Carolina

FAMILY PERDICIN艮.

PARTRIDGES.

GENUS ORTYX.

Partridge.

Ortyx Virginiana

Common American Partridge

FAMILY TETRAONINÆ.

GROUSE.

GENUS TETRAO.

Grouse.

Tetrao umbellus

"s cupido

\author{
Ruffed Grouse \\ Pinnated "
}

FAMILY RALLINÆ.

RAILS.

GENUS GALLINULA.

Gallinule.

Gallinula chloropus

" Martinica

Common Gallinule

Purple

GENUS FULICA.

Coot.

Fulica Americana

American Coot

GENUS ORTYGOMETRA.

Crake Gallinule.

Ortygometra Carolinus

Carolina Crake Gallinule

Novæboracensis

Yellow-breasted "

GENUS RALLUS.

Rail.

Rallus crepitans

“Virginianus

" elegans
Clapper Rail or Salt-water Marsh Hen Virginian Rail

Great Red-breasted " or Freshwater Marsh Hen

FAMILY CHARADRINAE.

PLOVERS.

GENUS CHARADRIUS.

Plover.

Charadrius helveticus

" marmoratus

“ semipalmatus

“ Wilsonius

" melodius

" vociferus
Black-bellied Plover

American Golden"

American Ringed"s

W'ilson's

Piping

Kildeer 
GENUS STREPSILAS.

Turnstone.

Strepsilas interpres Turnstone

GENUS HEMATOPUS. Oyster-calcher.

Haematopus palliatus Arnerican Oyster-catcher

\section{FAMILY SCOLOPACINIÆ.}

SNIPES.

Tringa islandica

"Bartramia

" alpina

" rufescens

" himantopus

" pecturalis

" maritima

" subarquata

" semipalmata

" pusilla

"Schinzii

Calidris (Tringa) arenaria

GENUS TRINGA.

Sandpipcr.

Red-breasted Sandpiper

Bartram's

Red-backed

Long-legged “ "

Pcctoral

Purple

Curlew

Semipalmated

Wilson's

Schinz's

Sanderling

GENUS PHALAROPUS.

Phalarope.

Phalaropus fulicariıs

Red Phalarope

GENUS LOBIPES.

Lobefoot.

Lobipes Wilsonii

"Hyperborcus

GENUS TOTANUS.

Wilson's Lobefoot

hyperborean "

'iatler.

Totanus flavipes

" vociferus

" semipalmatus

" solitarius

" macularius

Yellow-shanks Tatler

Tell-tale

Semipalmated "

Solitary " "

Spotted “

GENUS LIMOSA.

Godwit.

Limosa Fedoa

“. Hudsonica

Great Marbled Godwit

Hudsonian

66

GENUS SCOLOPAX.

Snipe.

Scolopax Wilsonii

"Noveboracensis

Wilson's Snipe

Red-breasted "

GENUS MICROPTERA.

Bogsucker.

Microptera Americana

American Woodcock 
XVIII

\section{GENUS RECURVIROSTRA.}

Avocet.

Recurvirostra American 3

American Arocet

GENUS HIMANTOPUS.

Stilt.

Himantopus nigricollis

Blach-nccked Stilt

GENUS NUMENIUS.

Curlew.

Numenius longirostris

"Hudsonicus

" borealis

I.ong-billed Curlew

Hudsonian

Esquimaux

FAMILY TANTALINAE.

IBISES.

Ibis alba

GENUS IBIS.

White Ibis

FAMILY ARDEINAE.

HERONS.

GENUS ARDEA.

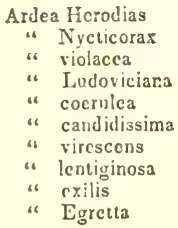

Great Blue Heron

Black-crowu'd Night Heron

Yellow-crowned

Loursiana

Blue

Sirowy

Green

Amcrican Bittern

Least

Grcat American White Egret

FAMILY ANATINAE.

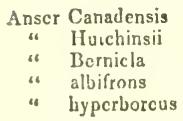

Anscr Canadensis

"Bernicla

" albifrons

“ hypcrborcus

\author{
DUCIKS. \\ GENUS ANSER. \\ Goose. \\ Canada Gooso \\ Hutchins " \\ Brent " \\ Whitc-fronted" \\ Snow
}


GENUS ANAS.

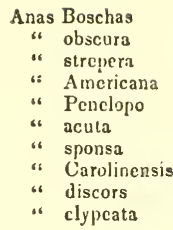

nas Boschas

: Americana

Penclopo

sponsa

ensis

" clypeata

Fuligula valisncriana

$\begin{array}{ll}\text { " } & \text { feriua } \\ \text { " } & \text { marila } \\ \text { " } & \text { rufitorques } \\ \text { " } & \text { rubida } \\ \text { " } & \text { Iabradora } \\ \text { " fusca } \\ \text { " } \\ \text { " } \\ \text { " Ampricillata } \\ \text { " mollissina } \\ \text { " spec ablis } \\ \text { clangula } \\ \text { " albeola } \\ \text { " histrionica } \\ \text { glacialis }\end{array}$

Fresh-watcr Duck.

Mallard
Dusky Duck
Gadwall
Amcrican Widgeon
Widgeon
Pintail
Summer Duck
Grees-winged Teal
Bluc-witged "“
Shoveller Duck

GENUS FULIGULA.

Sca Duck.

\begin{tabular}{|c|c|c|}
\hline Canvass-back & Duck & \\
\hline licd-headed & " & \\
\hline Scaup & "“ & \\
\hline Jes-er Scaup & " & \\
\hline Ring-necked or & tuficd I & Duck \\
\hline Ruddy & & " \\
\hline Pied & & “ \\
\hline Velie: & & “6 \\
\hline Surf & & "6 \\
\hline Scoter & & “ \\
\hline E der & & "، \\
\hline King & & "6 \\
\hline Go'den cye & & " \\
\hline Bulfel or Buffalo & o-headed & $d " 6$ \\
\hline Harlequin & & $"$ \\
\hline Long-tailed & & 4 \\
\hline
\end{tabular}

\section{FAMILY MERGINAE.}

MERGANSERS.

GENUS MERGUS.

\section{Mergus Merganser \\ “ cucullatus \\ “ serrator}

Merganser.

Bufl-breasted Merganscr or Gousander

Hivded

Red-brcasted Merganser

\section{FAMILY PELECANINÆ.}

PELICANS.

GENUS PHALACROCORAX.

Cormorant.

Phalacrocorax carbo “ dilopluse
Common Cormorant

Double-crestad " 
GENUS SULA.

Gannet.

Sula bassans

Common Ganuer

\section{FAMILY LARINÆ. \\ GULLS. \\ GENUS RHYNCHOPS. \\ Skimmer.}

Rhynchops nigra
Sterna Hirundo
“ minuta
“ Dougalli
“ nigra
“ Aruglica
“ Trudeauii
" Cayana

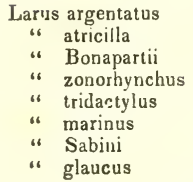

Black Skimmer

GENUS STERNA.

Tcrn.

$\begin{array}{lc}\text { Common } & \text { Tern } \\ \text { Least } & \text { “. } \\ \text { Roseate } & \text { “. } \\ \text { Black } & \text { "“ } \\ \text { Marsh } & \text { Trudeau's } \\ \text { Cayenne } & \text { “ }\end{array}$

GENUS LARUS.

Gulls.

$\begin{array}{lc}\text { Herring or Silvery Gull } \\ \text { Black-teaded } & \text { "، } \\ \text { Bonaparte's } & \text { Common or Ring-billed "“ } \\ \text { Kitliwake } & \text { "، } \\ \text { Great Black-backed } & \text { Fork-tailed } \\ \text { Glaucous } & \text { "“ }\end{array}$

FAMILY PROCELLARIN尼.

FULMARS.

GENUS LESTRIS.

Jager.

Lestris parasiticus,

" pomarinus

Arctic Jager

Pomarine "“

"Richardsonii

GENUS PUFFINUS.

Richardson's Jager

Shearwater.

Puffinus cinereus
“ $\quad \begin{aligned} & \text { anglorum } \\ & \text { obscurus }\end{aligned}$

Wandering Shearwater

Manks

Dusky

“

“6

GENUS THALASSIDROMA.

Petrel.

$\begin{array}{cl}\text { Thalassidroma } & \text { Wilsonii } \\ \text { " } & \text { Leachii } \\ & \text { pelagica }\end{array}$

Wilson's Petrel

Fork-tailed "“

Least

FAMILY ALCINÆ.

AUKS.

GENUS MORMION.

Mormon arcticu

Puffix.

Common or Arctic Puffin 
GENUS ALCA.

Alca Torda

Mergulus allo

Uria troile

" grylle
$A u k$.

Razor-billed Auk

GENUS MERGULUS.

Sea Dove.

Common Sea Dove GENUS URIA.

Guillemot. Foolish Guillemot Black

FAMILY COLYMBINAE.

DIVERS AND GREBES.

GENUS COLYMBUS.

Diver.

Colymbus glacialis

“ septentrionalis

Great Northern Diver

Red-throated

GENUS PODICEPS.

Grebe.

Horned Grebe

Pied-bill "

Crested "“

Red-necked " 


\section{ERRATA.}

Page 16, 9th line from bottom, for the large majority, read a large majority.

1710

195

31

315

34
$32 \quad 27$

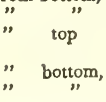
ceral

"than any of this genus"

" Caprimulgenae "preceding

"throat and a band on the sides of the neck, in form an inverted V-read-throat white, as also a band on the sides of the neck, which forn an inverted V. for Herendinae, read Hirundinae.

45 Ist and $2 d$ line spec. char., for-basal half of wings three fourth the length of tail feathers: sides of the body bright reddish-orange, read-basal half of wings three fourths the length of tail, and the sides of the body bright reddish-orange.

57 6th line from top, for first read finest.

8

$2612 \mathrm{~d}$ line from bottom, for tarsi read tail.

276 sth line from bottom, after eighteen, insert inches.

3125 th line from bottom, for crowns, read coverts.

3125 th line from bottom, for secondaries black, read inner, \&c.

3346 th line from top, for entire plumage white, read entire lower plumage white.

343 6th line from bottom, for tail of 11 feathers, read tail of 14 feathers.

$3492 \mathrm{~d}$ line from top, for eight read seven.

3.59 for Lanius read Larus.

362 for Larıs Sabina Sabinii read Lanus Sabini Sabine.

366 tirst line of spec, char. for length read breadth.

" third line from the bottom, for Maine read May.

37219 th line from top, for there read they.

380 1st line, before Racket Lake, insert the words-neighborhood of. 



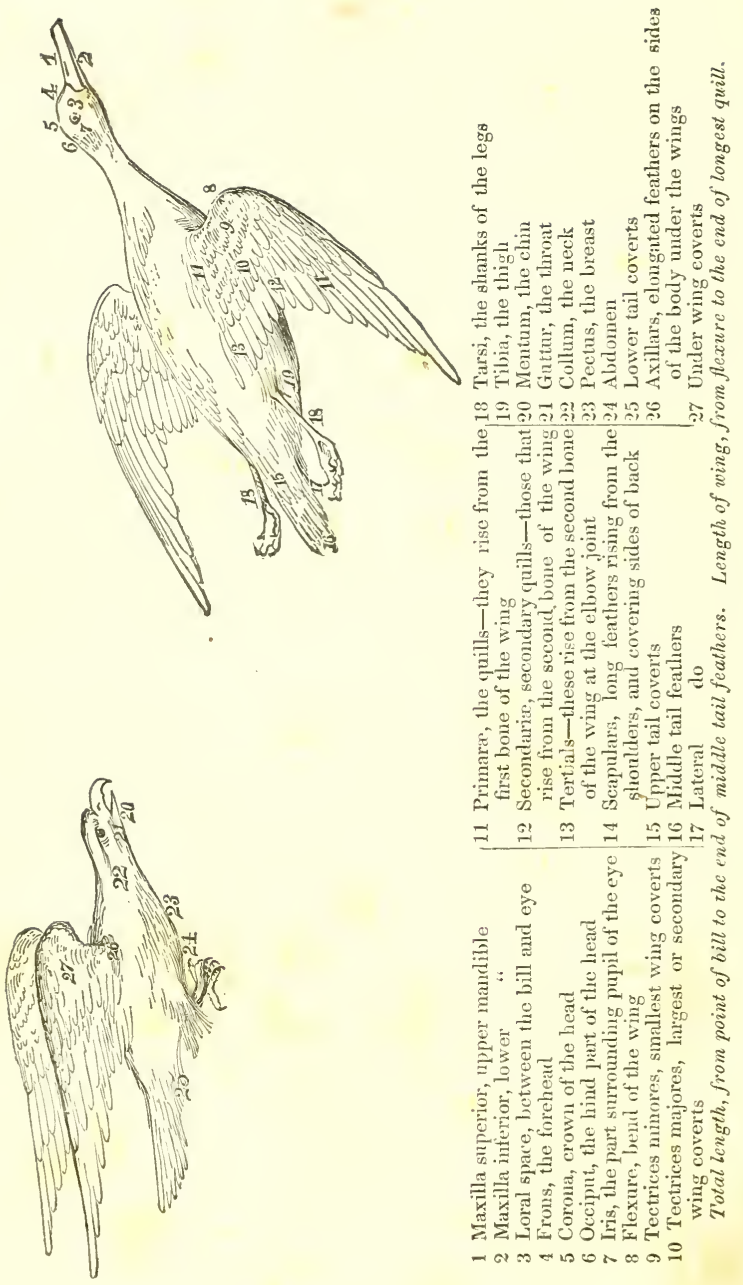




\title{
F A M I L Y V U L T U R I N
}

\author{
VULTURINE BIRDS.
}

\section{GENUS CATHARTES-ILLIGER}

\section{TURKEY VULTURE.}

[Biil of moderate length, rather slender, somewhat compressed-upper mandible with its dorsal outline nearly straight, covered to the middle by the cere ; nostrils oval, pervious, naked; head and upper part of the neck naked; body heavy; wings long and broad: tail nearly even, of moderate length; tarsi short; claws strong, arched.]

\section{CATHARTES AURA-LIŃN. \\ TURKEY VULTURE, OR TURKEY BUZZARD.}

Turkey Vulture, or Turkey Buzzard, Vulture aura, Wils. Amer. Orn.

Cathartes aura, Bonap. Syn.

Cathartes aura, Turkey Vulture, Sw. \& Rich.

Turkey Vulture, or Turkey Buzzard, Nutt. Man.

Turkey Buzzard, Cathartes aura, Aud. Orn. Biog.

Specific Characters-Head and upper part of the neck red. Adult with the head and neck red, naked; nape covered with short, downy feathers; plumage blackish-brown, deeper on the under parts; feet flesh-color, tinged with yellow. Young with the head and naked part of the neck dull flesh-color; wing-coverts spotted with dull white; in other respects, same as the adult. Length of adult two feet and a half, wing twenty-one inches and three quarters.

The Turkey Buzzard, well known in the Southern and Western States, is of rare occurrence in the vicinity of New York. In the 
State of New Jersey it is more common, and breeds there. Mr. Bell found it breeding at Cape May; the female was sitting on two eggs, which were deposited in the hollow stump of a decayed tree.

The Turkey Buzzard is noted for its ravenous and gluttonous disposition. After having regaled itself on the carcase of a dead horse or other quadruped, it retires to a neighboring fence or tree, where it remains for hours in stupid indolence, presenting a loathsome sight. In the southern cities it is protected by law, and performs the duty of scavenger, and is seen about the streets and market places in company with the Black Vulture, or Carrion Crow, [C. atratus] which is employed in the same service.

The food of the Turkey Buzzard is chiefly carrion, and when opportunity offers, it will sometimes gorge itself to such a degree as to be incapable of rising. In the New England States I am not aware that it is ever seen; stragglers only reach Long Island, and not long since, an individual was shot at English Neighborhood, a few miles above the city of New York. 


\title{
F A M I L Y F A L C O N I N E.
}

\author{
FALCONINE BIRDS.
}

\section{GENUS BUTEO-BECHET.}

\section{BUZZARD.}

[Upper mandible rounded, hooked, lobe obtuse ; sides of the lower mandible bent inwards ; head large, flattened above; neck short, body stout ; tarsi short, stout.]

\section{BU'TEO BOREALIS-GMEL. \\ RED-TAILED HAWK OR BUZZARD. \\ Red-tailed Hawk, Falco borealis, Wils. Amer. Orn. Buteo borealis, Red-tailed Buzzard, Sw. \& Rich. Red-tailed Hawk or Buzzard, Falco borealis, Nutt. Man. Red-tailed Hawk, Falco borealis, Aud. Orn. Biog.}

Specific Characters-Tail bright reddish-brown, with a narrow black band near the end. Adult male with the upper parts dark brown; the upper part of the head and hind neck lighter; wings dark brown, barred with black; tail bright reddish-brown, with a black band near the end and tipped with dull white; lower parts yellowish-white. Female with the lower parts white, and the color of the upper plumage rather duller than that of the male. Young with yellowish-red markings on the upper parts; lower parts yellowish-white, marked on the abdomen and sides of the body with longish spots of blackish-brown, and on the fore part and sides of the breast with reddish-brown; tail grayish-brown, tipped with white, with a similar band near the end, as in the adult, but lighter. Length of male twenty inches, wing fifteen. Female about three inches longer.

The Red-tailed or "Hen Hawk," is found in all parts of the United States, and is with us a constant resident. During summer it is said to be quite common in the Fur countries. 
Its flight is vigorous, and it is capable of sustaining itself on the wing for a long time. It sweeps over the surface of the ground in pursuit of mice and frogs, and performs its graceful and ærial evolutions at so great a height as to appear no larger than a Swallow. At this distance it carefully observes what is passing below-and should an object as small as an unfledged Partridge present itself, its fate is sealed. Having espied its prey, it suddenly checks its course, and usually alights on the nearest tree, from which it descends in such a direct line that it seldom misses the object of its pursuit.

Shy and suspicious, it is difficult to approach unless on horseback or in a wagon, when you can advance within gun-shot without exciting alarm. I have occasionally seen it sitting on the shrub oaks, though usually it alights on the uppermost branches of the tallest forest trees, and selects similar situations to build its nest. 


\title{
BUTEO PENNSYLVANICUS-WILSON.
}

\author{
BROAD-WINGED BUZZARD.
}

Broad-winged Hawk, Falco Pennsylvanicus, Wils. Amer. Orn.

Falco Pennsylvanicus, Bonap. Syn.

Broad-winged Hawk, Falco Pennsylvanicus, Nutt. Man.

Broad-winged Hawk, Falco Pennsylvanicus, Aud. Orn. Biog.

Specific Characters-Body compact ; tarsi rather short, feathered in front full half their length; wings exceedingly broad in proportion to the length of the body. Adult with the upper parts umber brown; tail dark brown, with two white bands; quills blackishbrown, the larger part of the inner webs white; a blackish-brown band from the mouth backwards; lower parts yellowish-white, marked with spots of dark brown, which markings are rather more numerous on the breast; body compact; tarsi rather short and strong. Young with the upper parts brown, the feathers margined and tipped with reddish-brown and white; tail grayish-brown, barred with darker; lower parts yellowish-white, marked with dusky spots. Length fifteen inches, wing eleven and a half. Female three inches longer.

The discovery of this species is due to Wilson, who met with two specimens in the woods near the Schuylkill, which appear to be all that came under his observation. On Long Island it is exceedingly rare, nor do I know of its being usually common any where in the vicinity of New York; though my friend Mr. Bell has informed me that he had the good fortune to obtain seven, and saw several others, during one day, when collecting in Rockland County ; but previous to, and since that period, he has seldom seen it. According to the observations of Mr. Audubon, in Virginia and Maryland, and in all the States to the eastward of these, it is by no means a scarce species. 


\title{
BUTEO LAGOPUS-VIGORS.
}

\author{
ROUGH-LEGGED BUZZARD.
}

\begin{abstract}
Black Hawk, Falco niger, Wils. Amer. Orn.
Falco lagopus, Bonap. Syn.

Buteo lagopus, Rough-legged Buzzard, Sw. \& Rich.

Rough-legged Falco lagopus, Aud. Orn. Biog.
\end{abstract}

Specific Character-Tarsi feathered their entire length. Adult with a white patch on the forehead and hind part of the neck; rest parts blackish-brown; wing quills and tail feathers white towards their bases, that color extending over the larger portion of the inner webs of the primaries; tarsi feathered to the toes. Young with the head and neck yellowish-white, streaked with dusky; the fore part of the breast of a more decided yellow, and marked with brownish black spots; the middle and lower portion of the breast blackishbrown; the rest of the lower parts pale yellowish-red; upper parts dark brown, the feathers broadly edged with yellowish-white and light reddish-brown; at the base of the tail feathers a broad band of pale yellowish-white, some of the feathers spotted with light reddish-brown. Length of male twenty-one inches, wing fifteen and three quarters. Female twenty-four inches and a half, wing seventeen and three quarters.

This is another species by no means common to Long Island. The few that I have met with I have observed coursing over the necks of land, and reconnoitering about the creeks in pursuit of mice and wounded birds, which are doubtless the attraction to these low, moist situations. The Rough-legged Buzzard displays much less activity on the wing than most other species; its flight is heavy, and it is usually seen passing low and leisurely over its hunting grounds. 


\title{
BUTEO LINEATUS-_GMEL.
}

\author{
RED-SHOULDERED HAWK.
}

Falco lineatus, Wils. Amer. Orn.

Winter Falcon, Falco hyemalis, Wils. Amer. Orn.

Falco hyemalis, Bonap. Syn.

Winter Falcon, or Red-shouldered Hawk, Falco hyemalis, Nutt. Man.

Red-shouldered Hawk, Falco lineatus, Aud. Om. Biog.

Winter Hawk, Falco hyemalis, Aud. Orn. Biog.

Specific Character-Lesser wing-coverts bright reddish-brown. Adult with the upper parts deep brown; fore part of the back darker, the feathers margined with reddish-brown; primaries blackishbrown, barred and tipped with white; secondaries barred and tipped with white, the outer webs shaded with reddish-brown; tail blackish-brown, distinctly crossed with four white bands, and rather broadly tipped with white; lesser wing coverts bright reddish brown, their centres marked with black; lower parts light reddish brown, longitudinally streaked with black; abdomen crossed with white; lower tail-coverts dull white, with a few brownish-red spots; tibial feathers yellowish-red, barred with deep reddish brown. Young with the upper parts brown, the feathers edged with dull white, and shaded with yellowish-red ; primaries blackish brown towards their ends; rest parts dull white, crossed with black, and shaded with yellowish-red; tail alternately barred with blackish-brown and grayish-brown; lower parts white, the ends of the feathers marked with large spots of hair-brown; tibial feathers tinged with dull yellowish-red; the red markings on the shoulders not so fully developed as in the adult. Length of male twenty inches, wing twelve and a quarter.

This fine Hawk, more plentiful than the preceding, is rarely observed with us except during winter. It possesses most of the manners of the Red-tailed Hawk, and like that species preys on poultry and small birds. 


\section{GENUS A QUILA-BRISSON。}

EAGLE.

[Bill very robust, angular above; tarsi feathered to the toes; feet very stout-middle toe longest, connected at base by a membrane.]

\section{AQUILA CHRYSAETOS-LINN.}

\section{GOLDEN EAGLE.}

Ring-tailed Eagle. Falco fulvus, Wils. Amer. Orn.

Royal or Golden Eagle, Nutt. Man.

Golden Eagle, Falco chrysætos, Aud. Orn. Biog.

Specific Character-Tarsi feathered to the toes. Adult with the bill bluish-gray; cere yellow; iris hair-brown; general color of plumage dark brown, glossed with purple; occiput, hind part and sides of the neck light brownish-yellow; wing-coverts light brown; primary quills brownish-black; tail rounded, the feathers dark brown, irregularly marked with dull white; lower tail-coverts light yellowish-brown, as are the feathers which cover the tibia and tarsi; feet yellowish; claws black. Young with the tail at the base white, which color continues about three-fourths its length. Length of male two feet six inches, wing twenty-five inches. Female six inches longer.

The finest specimen of this noble bird which I ever saw, was shot in the township of Islip, Long Island, and is now contained in the collection of the late H. C. De Rham. With us it is exceedingly rare, and it is not common in any part of the United States. Occasionally it is observed in the neighborhood of Niagara Falls. A few are distributed over our Western territory, and the specimen from which Wilson's figure and description were taken, was an immature bird shot in the county of Montgomery, Pennsylvania. 
The favorite abode of the Golden Eagle is the wild desert mountainous regions, and it is said to inhabit the northern parts of both continents.

"It is highly prized by the North American Indians, who make use of the tail feathers in constructing ornaments for their headsin ornamenting the calumet, or pipe of peace-and pluming their arrows."

The flight of this conspicuous bird is powerful and majesticthough according to Mr. Audubon, it has not the speed of many Hawks, nor even the White-headed Eagle.

The eyry of this species is built on high, inaccessible cliffs, and I have been informed that.it has been observed on the lofty peaks of the White Mountains in New Hampshire.

\title{
GENUS HALIAETUS-SA VIGNY.
}

\author{
SEA EAGLE.
}

[Bill very robust, convex above; head large, flattened above; body very largo; wings long; tail rounded; tarsi partly feathered; feet short, robust ; toes stout, free.]

\section{HALIAETUS LEUCOCEPHALUS-LINN.}

\section{WHITE-HEADED OR BALD EAGLE.}

Bald Eagle, Falco haliaetus, Wilson, (Aduit.)

Sea Eagle, Falco ossifragus, " (Young.)

Falco leucocephalus, Bonap. Syn.

Aquila leucocephala, White-headed Eagle, Sw. \& Rich.

White-headed or Bald Eagle, Falco leucocephalus, Nutt. Man.

White-headed Eagle, Falco leucocephalus, Aud. Orn. Biog.

Specific Characters--Lower portion of tarsi naked; head, neck, and tail white. Adult with the bill very strong; head and greater portion of the neck white; tail-feathers and their coverts also pure white; back, wing-coverts, breast, belly, and thighs, brownish black, the feathers margined with paler; wing quills brownish 
black, their shafts of a lighter color ; bill, cere, iris, tarsi, and feet, yellow; claws blackish-brown; feet and lower portion of tarsi naked. Young varying according to advanced stages; bill dusky ; plumage dark brown, head, neck, and tail-feathers paler, mottled and freckled with grayish-white, which gradually increases and assumes a more decided white appearance as the bird advances in age. Length three feet, wing twenty-three and three quarters.

This well known bird is an inhabitant of both Europe and America; in the United States it is met with along the whole extent of our sea-coast, as well as along the shores of the interior lakes and rivers, and is said to breed in the Fur countries. On Long Island, during winter, it is quite abundant. I have known from sixty to seventy to have been shot in one season.

It does not arrive at full plumage until an advanced age; the young, therefore, are by some thought to be a separate species, which they term "Gray Eagle." In general, it is supposed to appear in full plumage at about the fifth year; although I have been informed that a gentleman residing in Charleston, S. C., procured two young birds, and placed them in his aviary; on the fifth year, one appeared in full plumage, having the head and upper part of the neck and tail feathers white, while the mature plumage of the other was not fully developed on the ninth year.

The favorite food of this elegant bird is fish; and when such cannot be procured, it descends on small quadrupeds, and has been known to carry off lambs, and attack full grown sheep. Its great strength and power of wing enables it to hold the sway among the feathered inhabitants of the air ; and as the adopted emblem of our country, it is respected by all nations on the earth. Free and independent as are the happy people of this great and glorious republic, it roams about at will.

In summer it extends to the interior of the northern Fur countries. It frequents the shores of the Pacific, and its majestic flight is observed in all parts of the United States. It sweeps over the extensive prairies - follows the rapid course of the mighty Mississippi and other great arteries of the West-passes through the valleysand at pleasure ascends to the ethereal regions, until lost to the eye in space-delights in cascades and cataracts-bathes in the spray 
of the famed Niagara-and drinks from the foaming torrent. It wings its way to far distant lands, inspiring those who are strug. gling for freedom with the reflection that there exists a people unfettered with the chains of oppression, and who pay homage to none but their God.

I have never observed the nest on Long Island, although it has been found in the vicinity of New York, in the neighborhood of the Hudson River, at Pompton, N. J., and at "Heron Bay," seventy miles below Baltimore, by Mr. Bell. The nest, which is built of sticks and other coarse materials, is placed on the top of a high tree. An attempt to secure the eggs or young in the presence of the parents, is attended with considerable personal risk. They are very attentive to the wants of their offspring, and on approaching the nest, show much anxiety for their safety.

\section{GENUS PANDION-SAVIGNY.}

\section{OSPREY.}

[Bill short, as broad as deep at the base; tarsi strong, rough, naked; wing s very long, extending beyond the tail.]

\section{PANDION HALIAETUS-SAV.}

FISH HAWK, OR OSPREY.

Fish Hawk, Falco haliaetus, Wils. Amer. Orn.

Falco haliaetus. Bonap. Syn.

Fish Hawk, or Osprey, Falco haliaetus, Aud. Orn. Biog.

Specific Character-Wings very long, when folded extending beyond the tail; a broad band of blackish-brown behind the eye. Adult male with upper part of the head white; a blackish band behind the eye, with the fore part and sides of the neck streaked with brown; upper parts deep brown; quills towards the tips black; tail brown, the feathers barred with dull white on the inner web, and tipped with the same; lower parts white; wings extend- 
ing beyond the tail. Female, on the upper part of the head streaked with dark brown; the sides of the neck, lower neck, and fore part of the breast spotted and streaked with brown, and about two inches longer than the male. Length of male twenty-two inches, of wing eighteen.

The Osprey arrives among us in the latter part of March; and it is said its migrations extend as far as Hudson's Bay. Its flight is graceful and easy; at times it is seen making wide circles in the air, and when in pursuit of prey is seen passing low over the water, and at times it is observed perched on a dry limb that commands a view of a neighboring stream, intently gazing on the scene before it. The instant its prey is descried it descends with the swiftness of an arrow and gives pursuit to the luckless fish destined soon to struggle in the grasp of its keen-eyed destroyer. It seems to prefer taking its prey when at the surface, but when such opportunity does not offer it plunges into the stream and is usually successful in the effort, but is not at all times allowed to enjoy the fruits of its labor ; on rising with the game it is not unfrequently given chase by the Eagle, to which it yields the prize, utters an indignant scream, and passes on to follow in peaceful retirement the bent of its inclination. Its flesh being of no value to the sportsman, it suffers but little by the gun, and from the innocency of its character is allowed to pursue its avocation in peace and security. It subsists entirely on fish, which it takes alive, and at the commencement of cool weather, follows its finned prey to a more temperate climate. On the Islands lying in the vicinity of the eastern extremity of Long Island, great numbers breed. 


\title{
GENUS NAUCLERUS-VIGORS.
}

\author{
SWALLOW-TAILED HAWK.
}

[Bill short, wide at the base, much compressed toward the end-upper mandible with the dorsal line decurved from the base; head rather large, roundish, flattened ; neck short, body compact, feet short; tarsi very short, thick, scaly all round; plumage glossy; wings extremely long, pointed; tail extremely long, very deeply forked.]

\section{NAUCLERUS FURCATUS-LINN.}

\section{SWALLOW-TAILED HAWK.}

Swallow-tailed Hawk, Falco furcatus, Wils Amer. Ore.

Falco furcatus, Bonap. Syn.

Swallow-tailed Hawk, Falco furcatus, Aud. Orn. Biog.

Specific Character-Tail long, deeply forked. Adult with the head, neck all round, and lower parts white; back, wings, and tail black, glossed with blue and purple; feet light blue, tinged with green; claws flesh-colored; tail long and deeply forked. Length of male twenty-two inches, wing seventeen and a quarter. Female three inches longer.

In the summer of 1837 a specimen of this elegant species was shot while sailing over the south shore of Long Island, in the vicinity of Raynor South. It being the only individual that has been observed in this district, and so different from all our other Hawks, it was looked upon as a great curiosity by our gunners.

According to Wilson, "it inhabits the southern districts of the United States in summer: is seldom seen as far north as Pennsylvania, but is very abundant in South Carolina and Georgia-and still more so in West Florida, and the extensive prairies of Ohio and the Indiana territory. It is particularly attached to the extensive prairies of the western countries, where its favorite snakes, liz 
ards, grasshoppers, and locusts, are in abundance. They are sometimes, though rarely, seen in Pennsylvania and New Jersey-and that only in long and very warm summers."

The specimen in my possession was procured in South Carolina by Mr. Bell, who has informed me that when the brush is fired, the Swallow-tailed Hawk watches an opportunity to pounce upon rabbits as they escape from the flames-which, like the rest of its prey, it devours as it flies along.

\section{GENUS FALCO-LINN.}

\section{FALCON.}

[Bill short, robust, its upper outline decurved froin the base; cere short, bare; wings long, pointed; tail rather long, nearly even; tarsi of moderate length ; fcet strong ; claws long, curved, acute.]

\section{FALCO PEREGRINUS-GMEL.}

\section{PEREGRINE FALCON, OR GREAT-FOOTED HAWK.}

Great-footed Hawk, Wils. Amer. Orn.

Falco peregrinus, Bonap. Syn.

Common or Wandering Falcon, Falco peregrinus, Nutt. Man.

Great-footed Hawk, Falco peregrinus, Aud. Amer. Orn.

Falco peregrinus, Peregrine Falcon, Sw. \& Rich.

Specific Characters-A black patch on the sides of the head directly below the eye, inclining on the fore neck; feet and claws very strong; wings extending to the end of the tail. Adult with the upper parts grayish-black; head and hind neck barred with light grayish-blue; lower parts white; the breast and sides spotted with black; feet very large and strong; a black patch on the side of the head, directly below the eye. Female with the lower parts yellowish-white, marked on the breast and sides of the body with large black spots, the sides of the neck strealed with the same color; the patch below the eye same as the male. Young with the 
upper parts blackish-brown; lower parts yellowish or reddish-white; broadly streaked with dusky; the patch under the eye brownishblack. Length of male sixteen inches, wing twelve. Female nineteen inches, wing fourteen.

This species is well known to all those who practice Bay shooting by the name of "Duck Hawk." It frequents the bays and inlets, and preys on water-fowl, and is observed sailing over the shores and meadows in pursuit of smaller game. It frequently attends upon the fowler when he is decoying Ducks-and when opportunity offers, darts down upon the wounded bird-for which piece of temerity it often forfeits its life; and it is said, when hard pressed, will attack a flock of wild geese, carrying terror and dismay among their ranks.

The Great-footed Hawk is said to inhabit the North American continent, from one extremity to the other--as well as the continent of Europe. It possesses great courage and strength, and is capable of rapid fight.

"In the days of falconry, this bird was highly prized by the lovers of that princely amusement, the female being mostly valued and employed against larger birds-while the male, from its being onethird smaller, was denominated a ' tiercelet,' or, 'tercel,' and flown only at partridges and small game."-Fauna Boreali Americana. 


\title{
FALCO SPARVERIUS-LINN.
}

\author{
SPARROW HAWK.
}

\begin{abstract}
American Sparrow Hawk, Falco sparverius, Wils. Amer. Orn.
Falco sparverius, Bonap. Syn.

American Sparrow Hawk, Falco sparverius, Nutt, Man.

Falco sparverius, Little Rusty-crowned Falcon, Siv. \& Rich.

American Sparrow Hawk, Falco sparverius, And. Orn. Biog.
\end{abstract}

Specific Characters-Crown light red, surrounded with blue; on the sides of the neck two black bands; three spots on the hind neck, and numerous black spots on the abdomen and sides of the body. Adult male with the forehead, upper part of the sides of the head, occiput, and wing-coverts light grayish-blue; a patch of light red on the crown; the back of the same color, spotted with black; tail darker red, with a broad biack band near the end-the feathers tipped with white; lateral feathers white, broadly barred with black on the inner webs; spots of the same color close to the shafts on the outer webs; wings black, with white spots on the inner webs; throat and upper portion of the sides of the neck white; a black band before the eye passing down the sides of the throata similar band on the sides of the neck, behind which is a black spot; breast yellowish-white, (in some specimens the breast is tinged with red;) rest of the lower parts white, distinctly marked with round spots of black. Length of male eleven inches, wing seven.

With us this species cannot be said to be very plentiful. It arrives in spring, and a few remain during summer, but the larger majority pass on to other districts to spend the season of incubation. Its peculiar and handsome markings render it conspicuous, and I believe it is well known in all parts of the United States. We also find it enumerated with the birds of the northern Fur countriesand according to Dr. Richardson, it breeds in considerable numbers on the banks of the Saskatchewan, in the neighborhood of Carlton House-arriving there in the middle of April, laying its eggs about the middle of May, and retiring southward on the ap- 
proach of winter. The Sparrow Hawk displays less timidity than any of its genus. If the gunner advance cautiously, it permits a near approach, and not unfrequently alights near the farmer's dwelling. It preys chiefly on mice and small birds-and at times, with a boldness becoming to more destructive species, descends upon small chickens.

\section{FALCO COLUMBARIUS-LINN.}

\section{PIGEON HAWK.}

Pigeon Hawk, Falco columbarius, Wils. Amer. Orn.

Falco columbarius, Bonap. Sun.

Pigeon Hawk, Falco columbarius, Nutt. Man.

Falco columbarius, Pigeon Hawk, Sw. \& Rich.

Pigeon Hawk, Falco columbarius, Aud. Orn. Biog.

Specific Characters-Upper parts bluish-gray; lower parts yellowish-white; the breast and sides of the body marked with black; tail rather long, a little rounded, the outer feathers with five white bands, the middle feathers with four-all largely tipped with white -the space between the last band and the tips twice as great as that between the bands. Adult with the upper parts bluish-gray; the wing quills marked with large spots of reddish-brown; tail rather darker than the back, barred and tipped with dull white; low. er parts yellowish-white; the breast and sides of the body with oblong black spots. Young with yellowish-white markings on the sides and hind part of the head; lower parts yellowish-red, the ceral parts of the feathers streaked with blackish-brown; throat yellowish-white. Length of male, eleven inches and a half, wing seven and three quarters. Female about three inches longer.

On Long Island this spirited little Hawk is quite common, and according to some writers, its migrations extend to Hudson's Bay. Its food consists of small birds, and from its habit of attacking wandering flocks of Pigeons, it has received the name of "Pigeon Hawk," and is known to many as the "Bullet Hawk," so called from the velocity with which it descends upon its prey. It is noted for its daring thefts, and as a great destroyer of young poultry. 


\section{GENUS ASTUR-CUVIER.}

\section{HAWK.}

[In these birds, the lobe of the upper mandible is well defined ; tarsi slender tail long, rounded ; general form rather slender.]

\section{ASTUR PALUMBARIUS-LINN.}

\section{GOSHAWK.}

Ash-colored or Black-capped Hawk, Falco atricapillus, Wils. Amer. Orn. Falco palumbarius, Bonap. Syn.

American Goshawk, Falco atricapillus, Nutt. Man.

Accipiter (Asiur) palumbarius, Sw. \& Rich.

Goshawk, Falco palumbarius, Aud. Orn. Biog.

Specific Character-Crown black, and a broad band behind the eye brownish-black, over the eye a white band, the feathers along the shafts black; tarsi strong, feathered full half their length; tibial feathers very long, tail long and broad. Adult with the upper part of the head, and a broad band behind the eye passing round on the occiput, brownish-black; a white band over the eyes; upper parts slate color; the shafts black; the tail with four broad blackish-brown bands; lower parts gray, closely barred with white, the central part of the feathers dusky; under tail-coverts white, with a few grayish bands towards their bases. Young with the upper parts brown, the feathers edged with reddish-white; the head and hind neck pale red, streaked with dark brown; lower parts yellowish-white, with oblong spots of dark brown. Length of male twenty-four inches, wing thirteen and a quarter. Female twenty-six inches, wing fourteen and three quarters.

In the United States this is not a very common species. On Long Island it is quite rare. An adult, now in my possession, was shot in the township of Islip, in the summer of 1838. So seldom is it seen in this vicinity, particularly in this state of plumage, that it was entirely unknown to the inhabitants.

"It is considered by Ornithologists identical with the Goshawk of Europe, which for its strength and spirit was so much esteemed in falconry." 


\title{
ASTUR FUSCUS-GMEL.
}

\author{
SHARP-SHINNED HAWK.
}

Slate-colored Hawk, Falco velox, Wils. Amer. Orn.

Sharp-shinned Hawk, Falco velox, Bonap. Syr.

Accipiter Pennsylvanicus, Slate-colored Hawk, Sw. \& Rich.

American Brown or Slate-colored Hawk, Nutt. Man.

Sharp-shinned or Slate-colored Hawk, Falco fuscus, Aud. Amer. Orn.

Specific Character-Tarsi long, very slender. Adult with the upper part of the head dark brown; back slate color; the tail with four brown and distinct bands, the tips white; lower parts barred with light red and white; wings brownish-black; tarsi more slender than any of this genus. Young, with the upper parts dark brown; lower parts yellowish-white, broadly streaked with reddish-brown. Length of male eleven inches, wing six and three quarters. Female about two inches and a half longer.

This species is found in all the Atlantic States, On Long Island it is not very abundant. In spirit it is not surpassed by any of its tribe. Its flight is performed in an irregular and vigorous manner, and at times ascends to a very great elevation. It preys on mice, lizards, and small birds, and like the rest of its tribe, visits the poultry yard.

With this species, as is the case with all the rest of the Hawks, we find they vary much in measurement. Thus we see that in most cases length and extent can be used only as auxiliaries to specific characters. Of the present species I have seen adult males considerably less than our measurement, and I have now before me a young female the length of which is fifteen inches. 


\section{ASTUR COOPERII-BONAP.}

\section{COOPER'S HAWK.}

Cooper's Hawk, Falco Cooperii, Bonap. Amer, Orn.

Falco Cooperii, Bonap. Syn.

Stanley Hawk, Falco Stanleii, Aud. Orn. Biog.

Specific Characters-Tarsi two inches and a half long, which, with the feet, are much stronger than those parts of the preceding species, but not so robust, nor has it the tarsi so fully feathered, or the tibial feathers as long as has the Goshawk. Tail rounded with four black bands and tipped with white. Adult with the upper part of the head brownish-black; back brown; the fore part darker; tail same as the back, banded with black and tipped with white; lower parts reddish-brown, barred with white, the shafts black, giving it a striped appearance ; lower tail-coverts white; tibial feathers of a deeper color than the lower parts, and faintly barred with white; tarsi strong; tail rounded, the middle pair of feathers nine inches and a half long. Young with the lower parts pale yellowish-white, marked with long spots of dark brown. Length of adult male nineteen inches, wing eleven inches. Like all rapacious birds, the female is the largest.

This rather common species is distributed over the United States, and according to Mr. Nuttall, seen in the Oregon Territory to the shores of the Pacific. It preys on various species of birds, and sometimes descends upon small quadrupeds. In our section, during winter, I have never observed it, and I am not aware that if breeds here. 


\section{( 21$)$}

\section{GENUS CIRCUS.}

\section{HARRIER.}

[General form slender ; tarsi elongated, slender ; tail long, nearly even; wings long, rounded; the face surrounded with a kind of collar of rigid feathers.]

\section{CIRCUS CYANEUS.}

\section{COMMON HARRIER, OR MARSH HAWK.}

Marsh Hawk, Falco uliginosus, Wils. Amer. Orn.

Falco cyaneus, Bonap Amer. Orn.

Hen Harrier, or Marsh Hawk, Nutt. Man.

Marsh Hawk, Falco cyaneus, Aud. Orn. Biog.

Buteo (Circus) cyaneus? var? Americanus, American Hen Harrier,

Sw. \& Rich.

Specific Character-Tarsi long, slender; tail long, straight, the feathers rather broad; upper tail-coverts and basal parts of tail feathers white. Adult with the upper parts ash brown, the upper part and sides of the head streaked with yellowish-red; primaries blackish-brown-the inner webs towards their bases white; outer webs shaded with grayish-blue, as are those of the secondaries; fore neck and upper part of the breast brownish-red, the feathers with dull white spots-rest of the lower parts white, the feathers barred and spotted with light red; tibial feathers white, with central light red spots; upper tail-coverts and basal part of the tail feathers white-as are the greater portion of their inner websthe outer two barred with blackish-brown and light red-the rest crossed with fine bars of blackish-brown; the outer webs shaded with grayish-blue; the tail-feathers long, straight, broad and rounded at the ends, which are dull white. The specimen from which this description is taken is not in full plumage, though quite as fully developed as we usually see it. At maturity, the upper parts and fore part of the breast are pale blue-the rest of the lower parts white. Length twenty inches, wing thirteen.

Among us the Marsh Hawk or Harrier is a constant resident. It is commonly seen sailing over the salt marshes and meadows in quest of mice. Although it is seldom that we visit its favorite resort without seeing several individuals, yet with us a specimen in 
mature plumage is rarely met with. Whether it does not appear in full plumage until a very advanced age, or that the adults associate apart from the young, and do not in general visit this section, I cannot say.

In the Fauna Boreali Americana it is said to be a common species in the Fur countries, where they arrive in the latter end of April, and depart at the close of September. "On the plains of Saskatchewan only mature birds were seen, and none but the young on the shores of Bear Lake." The Prince of Musignano observes that they are to be found in all varieties of plumage in Florida, but that in the Northern States the young only are known. I have seen a few adults said to have been shot on the south side of Long Island.

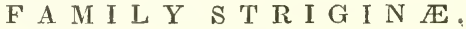

OWLS.

GENUS SURNIA-DUMERIL.

DAY OWL.

[Opening of the ears oval, and of moderate size; the feathers around the face slender, indistinct; head without tufts-diurnal.]

\section{SURNIA NYCTEA-LINN.}

\section{SNOWY OWL.}

Snowy Owl, Strix nyctea, Nutt. Man.

Snowy Owl, Strix nyctea, Aud. Orn. Biog.

Specific Character-Plumage white; head and back marked with dusky spots; lower parts and tail feathers barred with blackish brown; female about three inches longer, with the dusky bands more numerous and broader. Young pure white. Length twenty two inches, wing eighteen.

The Snowy Owl is said to inhabit the Arctic regions of both continents. In winter they enter the United States, and at that sea- 
son have been observed along the southern portion of the sea coast of the United States. A few are seen every winter on the south side of Long Island. It is usually found on the beach, where it is doubtless attracted by the dead fish thrown up by the sea. It is also said to prey upon hares and small birds. In its habits it is diurnal as well as nocturnal. When alarmed, it takes wing, uttering a loud and dismal cry.

A friend residing on the Island having wounded a specimen in the wing, brought it home alive, and kept it in confinement several weeks. Among other articles of food he offered it live rats, which it devoured greedily.

\section{GENUS ULULA-CUVIER.}

\section{NIGHT OWL.}

[Bill robust, curved from base ; feathers of the face fully developed; head without tufts ; tail slightly rounded, of moderate length ; habits nocturnal.]

\section{ULULA ACADICA-GMEL.}

\section{ACADIAN OWL.}

Little Owl, Strix passerina, Wils. Amer. Orn.

Strix acadica, American Sparrow Owl, Sw. \& Rich.

Acadian Owl, Strix acadica, Nutt. Man.

Little or Acadian Owl, Strix acadica, Wils. Amer. Orn.

Specific Characters-Head without tufts; tail short, with three narrow white bands; disk pale yellowish gray; bill bluish-black. Adult with the upper parts tinged with olive brown; first six primaries with white markings on both webs; secondaries, scapulars, and some of the wing coverts spotted with white; tail brown, with bands of white and tipped with the same color; lower parts white, very broadly streaked with reddish-brown. Length seven inches and a half, wing five and a half.

This, the smallest of its tribe that has been observed in this vicinity, is said to inhabit the northern regions of both continents. With us it is quite rare. In the swamps along the sea coast of Maryland and New Jersey, it is said to be more common. It is seldom seen flying in the day time excepting when disturbed; at such times it 
flies off to the nearest thicket, and resumes its slumbers. Towards evening it becomes quite active, and pursues its prey in a spirited manner. It is occasionally observed in cities. In the early part of June of last year, a specimen was shot in St. Paul's church-yard, in the city of New York.

\section{GENUS S Y R NIUM-CUVIER.}

\section{HOOTING OWL.}

[Conch of the ear very large; disk of slender feathers complete; feet and toes feathered; tail broad, rounded; head without tufts.]

\section{SYRNIUM NEBULOSA-LINN.}

\section{BARRED OWL.}

Barred Owl, Strix nebnlosa, Wils. Amer. Orn.

Strix nebulosa, Bonap. Syn.

Barred Owl, Strix nebulosa, Nutt. Man.

Barred Owl, Strix nebulosa, Aud. Orn. Biog.

Specific Character-Upper parts, fore neck and breast with transverse white bars; abdomen and flanks dull white, tinged with yellow; the feathers with broad longitudinal brown streaks, tail rather long rounded. Adult with the upper parts light reddish brown, barred with white, as are the tail, fore neck, and upper portion of the breast, that color predominating on the latter two-rest of the lower parts yellowish-white, broadly streaked with brown; tail rounded. Length seventeen inches and a half, wing fourteen

This species is found in all parts of the United States-in the Southern States it is most common. Its food consists chiefly of mice and small birds; at times, domestic fowls, partridges, and young rabbits, contribute to its support.

Although frequently observed flying during the day, their sight at such times is quite dim, as the following circumstance will show:-My friend J. G. Bell informs me that when on a collecting tour in South Carolina, and while intent on looking for the Bluewinged Yellow Warbler, whose note he had a moment before heard, he was startled by feeling a sudden pressure on his gun. Judge of his surprise when he perceived perched on the barrels of 
his gun the Barred Owl, which at the same moment discovered its mistake-and while endeavoring to retrieve the fatal error, was shot down by the astonished gunner.

The wing quills are furnished with soft and downy feathers, which enable it to pass through the air in a noiseless manner. I found it very abundant in the marshes and forests in the neighborhood of New Orleans; indeed you can scarcely make even a short excursion from the city without meeting with several specimens.

\section{GENUS OTUS-CUVIER.}

EARED OWL.

[Bill short, stout, compressed toward the end ; head furnished with rather long tufts of feathers; tail rather short, a little rounded.]

\section{OTUS VULGARIS-FLEMING.}

LONG-EARED OWL.

Strix otus, Wils. Amer. Orn.

Strix otus, Bonap. Syn.

Long-eared Owl, Strix otus, Nutt. Man.

Long-eared Owl, Strix otus, Aud. Orn. Biog.

Specific Character-Tufts elongated; upper parts mottled with dark brown grayish-white and reddish buff; lower parts streaked and crossed with dark brown and marked with large white spots; the feathers towards the base reddish buff; tail with twelve narrow blackish-brown bands; the middle pair with nine broader bands. Adult with the tufts long; head with small brown and dull white spots ; uppper parts mottled; primaries barred with buff and dusky toward the tips, with greenish-brown and brownish black; tail with narrow blackish-brown bands, and tipped with white. Length fourteen inches; wing twelve.

This is another of those nocturnal wanderers that are said to inhabit generally the North American continent. In plumage it is nearly allied to the Short-eared Owl, from which it is at all times distinguishable by the greater length of the tufts or ear feathers. With us, I have only known it to occur during winter, and have usually observed it in the woods or thickets. 


\title{
O'TUS BRACHYOTOS-LINN.
}

\author{
SHORT-EARED OWL.
}

Short-eared Owl, Strix brachyotos, Wils. Amer. Orn.

Sirix brachyotos, Bonap. Syn.

Short-eared Owl, Strix brachyotos, Nutt. Man.

Short-eared Owl, Strix brachyotos, Aud. Orn. Biog.

Specific Character-Tufts much shorter than the preceding; plumage reddish buff, longitudinally streaked with dark brown; tail dark brown broadly barred and tipped with reddish buff. Adu't with the upper parts dark brown, variegated with reddish buff; tufts short; eye surrounded with black; lower parts buff, streaked with dark brown; lower tail coverts yellowish-white without spots; tail alternately barred with reddish-buff and dark brown; quills reddish-buff, marked on both webs with dark brown, of which color are the tips. Length fifteen inches, wing thirteen and a quarter. Female about two inches longer.

Dr. Richardson states that during summer this species is by no means rare in the Fur countries, arriving as soon as the snow disappears, and departing again in September. That it sometimes remains in the United States throughout the year is quite evident from the fact of Mr. Audubon having found its nest on one of the high mountain ridges of the Great Pine Forest on the seventeenth day of June. The nest was placed under a low bush and covered over with tall grass. The eggs were four in number, of a dull white color, and nearly hatched. On Long Island it is not common, and seems to be only a winter visitant, and is usually observed on the meadows and marshes. 


\title{
GENUS BUBO-CUVIER.
}

\author{
HORNED OWL.
}

[Bill broader than high at base; conch of the ear very large, extended semicircularly from the bill to the top of the head; disk perfect; head with elongated tufts ; tail rounded.]

\section{BUBO VIRGINIANUS-GMEL.}

Great Horned Owl, Strix Virginiana, Wils. Amer. Orn.

Strix Virginiana, Bonap. Syn.

Great Horned Owl, or Cat Owl, Strix Virginiana, Nutt. Man.

Great Horned Owl, Strix Virginiana, Aud. Orn. Biog.

Specific Character-A broad white band on the fore-neck; upper parts mottled with greyish-white, blackish-brown and yellowish-red; lower parts transversely barred with dusky. Adult with the face reddish-brown, surrounded with black; bill black; the tufts are about three inches long, composed of twelve or fourteen black feathers, edged with brownish-yellow; upper parts mottled with grayish-white, brownish-black and yellowish-red; lower parts light yellow, transversely barred with dusky; wings brownish-yellow, barred and mottled with blackish-brown; tail rounded, extending about an inch beyond the wings; a white band across the fore neck; space between the bill and eyes dusky, the feathers tipped with grayish white. Length twenty-two inches, wing fifteen and three quarters.

This large and common Owl is very generally distributed over the different sections of the United States. Its choice of residence is the dark and swampy parts of the forests, where it reigns in solitude. Farmers know it well by the frequent thefts committed on their poultry, as well as from the loud and dismal noise it makes at all hours of the night. 
On Long Island it is not very common, and I believe is no where so abundant as in the Western forests. Selecting the deep and impenetrable parts of the woods, this nightly disturber of the peace reposes by day in security and silence. At night it prowls about in quest of prey, and often provokes its destruction by descending upon the scanty stock of the new settler.

Its food consists of small quadrupeds and birds. It nests in a hollow tree. The eggs, which are four in number, resemble in size and color those of the common hen.

\section{BUBO ASIO-LINN.}

\section{MOTTLED HORNED OWL.}

Mottled Owl, Strix naevia, Wils. Amer. Ōn.

Red Owl. Strix asio, Wilson (Y oung.)

Mottled Owl, Strix naevia, Nutt. Man.

Red Owl, Strix asio, Nuttall (Young.)

Little Screech Onl, Strix asio, Aud. Orn. Biog.

Specific Character-General color of plumage gray, spotted and streaked with black; young brownish-red. Adult with the upper parts pale brown, spotted and dotted with brownish-black; a pale gray line from the base of the upper mandible over the eye; quills light brownish-gray, barred with brownish-black, their coverts dark brown; secondary coverts tipped with white; throat yellowish gray; lower parts light gray, patched and sprinkled with brownish-black.

Young, with the upper parts light brownish-red, the feathers with central blackish-brown lines; lower parts paler, the feathers more broadly streaked with black; middle of abdomen, a line over the eye, and tips of the secondary coverts, reddish-white. Length ten inches, wing seven.

The specimen from which the following description is taken is not in full plumage. I have thought proper to make use of it in order to trace more closely the change which it undergoes before arriving at maturity. 
Upper parts dark gray, tinged with light brown-the feathers with central black streaks, and numerous irregular transverse dusky markings; quills brownish-gray, barred with brownish-black, the outer vanes with white spots shaded with pale reddish-brown; secondary coverts and scapulars with the outer webs white; a gray band from the base of the upper mandible over each eye, bounded next to the eye with brownish-red, of which color are the outer feathers of the tufts; face dark gray, the feathers crossed with blackish; a black band on the sides of the neck meeting on the fore neck, where it becomes mottled with black reddish-brown and grayish white; breast and sides of the body gray, the feathers crossed with dusky, their central parts broadly streaked with black and has numerous spots of reddish-brown over the entire lower parts excepting the middle portion of the abdomen, which is white; thighs pale yellowish-red.

The Screech Owl is found in almost every part of the United States. In the Southern States it is quite rare. Mr. Audubon states that during a long residence in Louisiana he met with but two specimens. With us it is very common; it is usually found in the woods and orchards; its food is chiefly mice and small birds.

One of the few errors made by the lamented Wilson, was in describing the young of this bird as a distinct species. Considering all the disadvantages under which he labored, it is surprising that in his excellent work so few mistakes should have occurred. Had he lived to complete his laudable, and at that period (in this country) novel undertaking, no doubt the corrections that have fallen to the task of others, would have been made with his own pen.

From the very satisfactory observations made by the distinguished author of the Birds of America, I supposed it to be a received opinion among Ornithologists, that the young of the Screech Owl is red. In a recent publication, the author has described the bird in red livery as a distinct species, and has stated that the young of the Screech Owl is of similar color as the adult. Shortly after this publication, I received from J. G. Bell, of Rockland County, the following communication: 


\section{"Dear Sir-}

"In looking over Mr. Nuttall's late edition of the Land Birds, I notice that he has, on the authority of Dr. Michener, repeated, in my opinion, the error committed by Wilson, by describing the Red Owl, Strix naevia of Wilson, as a distinct species, which $\mathbf{I}$ consider as the young of Strix asio. This opinion I have not hastily arrived at-it is the result of several years' close observation. I have taken the young birds from the nest soon after they were hatched, and found them covered with grayish down. As soon as the feathers begin to form, they assume a reddish appearance, the color becoming deeper as the bird advances in age. How long they remain in this plumage I cannot say, but am inclined to the opinion that in some instances they do not appear in full plumage until the second or third year-as I have taken the female from the nest, she being in mature gray plumage, and at the same time I have shot the male, he being perched a few feet above her on the sametree, and in the red livery. On the first occurrence of this, I supposed the plumage of the female to be gray, and that of the male red. Subsequently, however, I was obliged to abandon this position, for directly the opposite occurred; and I have shot both male and female in either dress, and am well persuaded that they mate before arriving at maturity.

"Yours truly,

J. G. BeLL," 


\title{
F A M I L Y C A P R I M U L G E N $\mathbb{E}$.
}

\section{GOAT SUCKERS.}

\author{
GENUS CAPRIMULGUS-LINN.
}

\section{GOAT SUCKER.}

[Bill extremely short, feeble, opening beyond the eyes, much depressedsomewhat hooked at tip; head very broad; eyes large ; body slender ; wings long pointed; tail of ten feathers, long and rounded; tarsus partly feathered; feet very small.]

\section{·CAPRIMULGUS VOCIFERUS-WILSON. WHIP-POOR-WILL. \\ Whip-poor-will, Caprimulgus vociferus, Wils. Amer. Orn. \\ Caprimulgus vociferus, Bonap. Syn. \\ Whip-poor-will, Caprimulgus vociferus, Aud. Orn. Biog. Whip-poor-will, Caprimulgus vociferus, Nutt. Man.}

Specific Character-A band on the fore neck and wings white, which color predominates on four of the tail featlıers. Adult with the upper parts dark brownish gray, streaked and barred with black; lower parts lighter and more distinctly barred; wings spotted and barred with light brownish red, on the outer four primaries, a white band towards the ends; a broad white band on the fore neck; tail much longer and broader than that of the Night Hawk, the four middle feathers of the same color as the back-the larger portion of the next two white, the outer feather black, with a portion of the inner web white. Length nine inches and a half, wing six and a half. Female with the plumage duller.

The Whip-poor-will, so called from the resemblance of its notes to those syllables, is quite common to Long Island. By many it is considered identical with the preceding species, to which it bears some resemblance. It is seldom seen abroad by day, that part of its time is passed in the deep and shady parts of the woods in silence and repose. At night, when roaming about in quest of food, it utters its well known and melancholy cry. 
It arrives on Long Island about the first of May, from the South. In the latter part of the same month the female commences laying. For this purpose the least frequented parts of the woods are selected. The eggs are deposited on the ground, and in form resemble those of the Night Hawk-the color is grayish-white, marked all over with dark olive.

\section{GENUS CHORDEILES-S W A INSON.}

NIGHT HAWK.

[Closely allied to the preceding Genus (Caprimulgus.) Bill extremely sinall ; mouth opening to beneath the centre of the eyes; upper mandible declinate at tip ; head and eyes large ; wings long, pointed ; tail emarginate.]

\section{CHORDELIES VIRGINIANUS-BRISS.}

NIGHT HAWK.

Night Hawk, Caprimulgus Americanus, Wils. Amer. Orn.

Caprimulgus Virginianus, Bonap. Syn.

Caprimulgus (Chordeiles) Virginianus, Sw. \& Rich.

Night Hawk, Caprimulgus Americanus, Nutt. Man.

Night Hawk, Caprimulgus Virgınianus, Aud. Orn. Biog.

Specific Character-Throat and a band on the sides of the neck in form an inverted V. Adult with the upper parts brownish-black; mottled with white and pale reddish-brown; lower parts grayish white, barred with blackish-brown; wings and tail feathers brownish black, on the former a white band on the first five quills; the latter barred with brownish-gray, the outer four feathers on each side plain brownish-black toward the end, with a large white spot; throat and upper part of the sides of the neck white. Female rather larger, the white markings on the throat tinged with reddish-brown and the white spots on the tail feathers wanting. Length nine inches, wing seven and three quarters.

Early in May the Night Hawk makes its appearance on Long Island. Its migrations are said to extend to the fur countries. About an hour before sunset they are seen flying about in pairs. Although this seems to be a favorite time for its ærial excursions, yet it is sometimes seen at all hours during day, darting through the air in quest of its favorite insects. It is known to many persons by 
the name of Night Jar, from the harsh noise it makes when flying about towards evening.

In the latter part of May the female commences laying. The eggs, two in number, are pointed at both ends, the color dull white; spotted all over with dull olive, and shaded with pale blue, and are placed on the ground, usually in a cultivated field.

From the formation of its feet and legs, which are too short to grasp the branches, it is always observed, when perched, sitting lengthwise. In the latter part of August it migrates southward.Its flesh is esteemed excellent.

\section{F A M I L Y C Y P S E L I N E.}

SWIFTS.

\section{GENUS CHÆTURA-STEPHENS。}

SPINE-TAIL.

[Bill extremely short, very broad at base-upper mandible slightly notched at tip-mouth opening to beneath the hind part of the eyes ; feet remarkably short - toes divided - hind toe versatile - wings extremely long - tail of ten feathers.]

\section{CHETURA PELASGIA-LINN.}

\section{CHIMNEY SWALLOW, OR AMERICAN SWIFT.}

Chimney Swallow, Hirundo pelasgia, Wils. Amer. Orn.

Cypselus pelasgia, Bonap. Syn.

Chimney Swift or Swallow, Cypselus pelasgius, Nutt. Man.

Chimney Swallow or Amerıcan Swift, Cypselus pelasgius, Aud. Orn. Biog.

Specific Character-General color sooty brown; the shafts of the tail feathers continue beyond the webs, and terminate with sharp points. Length four inches and a half, wing five and one eighth.

The Chimney Swallow, so called from the habit of building its nest in unoccupied chimneys, is, like the rest of its tribe, migratory. It arrives among us in the early part of May, and soon commences the formation of its nest, the materials of which are small dry sticks, glued against the wall with saliva.

On the authority of that distinguished traveller, General William 
Clarke, Mr. Audubon informs us that the Chimney Swallow is met with on the whole route across the continent to the Pacific Ocean. In those parts of the country where civilization is not sufficiently extended to accommodate it in the comfortable manner mentioned above, it has recourse to the trees and rocks. It rears two broods in a season; the eggs are pure white, and from four to six in number.

Like the Swallow, it drinks while on the wing, sipping the water as it passes over it, and snaps up flies and other winged insects that swarm on the surface. It seldom alights on the ground, though it passes quite near it. At times it soars to a great elevation, and pursues its irregular course with considerable velocity. It frequents the towns and villages, and its twittering note is heard in the large cities. It alights on the roofs of lofty buildings, and mounts to the tops of towering steeples, sometimes building its nest there.

\section{F A M I L Y H E R E N D I N E.}

\section{SWALLOWS.}

\section{GENUS HIRUNDO-LIN N.}

SWALIOOW.

[Bill very short, brood at the base, depressed, cleft nearly to the eyes-upper mandible notched; head broad; wings very long, narrow, pointed; tail of twelve feathere, generally emarginate; tarsi short, slender; feet small.]

\section{HIRUNDO PURPUREA-LINN.}

\section{PURPLE MARTIN.}

Purple Martin, Hirundo purpurea, Wils. Amer. Orn.

Hirundo purpurea, Bonap. Syn.

Purple Martin, Hirundo purpurea, Nutt. Man.

Purple Martin, Hirundo purpurea, Aud. Orn. Biog.

Specific Character-Adult male with the plumage shining purplish black, with steel blue reflections; wings and tail feathers brownish-black. Female with the upper parts duller; the lower parts light gray, and streaked with black; wings lengthy; tail deeply emarginate. Length seven inches and three quarters, wing six inches. 
The Purple Martin is said to be observed throughout the whole of North America, and from its familiar habits is equally well known. In the towns and villages, scarcely a sign-post is erected without a comfortable dwelling for this favorite bird. In the absence of such accoinmodations, it resorts to the eaves of a house or barn-and according to Dr. Richardson, in many Indian villages, excavated gourds are hung up for the Purple Martin to breed in.

The flight of the Martin is easy and graceful. It is frequently seen it sailing in the air with so little apparent effort, that featherlike it seems to be floating along; or when skimming swiftly over the surface of the ground, as if by a sudden impulse, darts•upward, until the eye fails to measure the distance.

The Purple Martin arrives among us from the South usually in the early part of April. It soon commences preparing its nest, which is formed of hay, straw, dried leaves, and feathers. 'The eggs, four in number, are pure white. In autumn it returns southward, and it is said to migrate far within the tropics.

\section{HIRUNDO RUSTICA-LINN.}

\section{BARN SWALLOW.}

Barn Swallow, Hirundo Americana, Wils. Amer. Orn.

Hirundo Americana, American Barn Swallow, Sw. \& Rich.

Hirundo rufa, Bonap. Sys.

Barn Swallow, Hirundo rufa, Nutt. Man.

Barn Swallow, Hirundo rustica, Aud. Orn. Biog.

Specific Character--Tail deeply forked. Adult with the upper parts steel blue, a band of similar color on the fore neck; forehead, throat, and lower parts chestnut; wings and tail brownish-black, glossed with green; a white spot on all the feathers excepting the middle pair; tail deeply forked. Female with the colors similar. Length seven inches, wing four and three quarters.

Naturalists having clearly established the fact relative to the migration of Swallows, the idea of their remaining during winter in a torpid state has become obsolete.

The Barn Swallow, like all other species, drinks and pursues its insect prey on the wing-and those who are familiar with its habits 
well know its fondness for bathing, and the rapid manner in which this operation is performed. Descending with the swiftness of an arrow, it dips into the water, turns, twists, and darts off in a zig-zag line, so that a casual observer might lose sight of it entirely, from the rapidity with which it changes its course, or suppose it to be a different specimen.

Early in the spring swallows are sometimes so benumbed as to be almost in a lifeless state. T'his is readily accounted for by the cold storms that set in after their arrival, which also cut off their insect food-at such times they have been found so much exhausted as to be unable to rise, and in some instances have been observed lying dead about the fields.

\section{HIRUNDO BICOLOR-VIEILL.}

\section{WHITE-BELLIED SWALLOW.}

Green-blue or White-hellied Swallow, Hirundo viridis, Wils. Amer. Orn. Hırun lo bicolor, Bonap. Syn.

White-belled Swhllow, Hirunilo bicolor, Nutt. Man.

White-bellied Swallow, Hirundo bicolor, Aud. Orn. Biog.

Specific Character-Upper parts glossy green; lower parts white, Adult, wings and tail brown; wings, when shut, extend about two inches beyond the tail, which is forked; bill black; feet purplish flesh color. Female with the plumage duller. Length five inches and a half, wing four and three quarters.

Mr. Audubon traced this species on the Atlantic coast from Texas to Labrador, and it is stated by Dr. Richardson to frequent the woody districts up to the sixtieth parallel. The White-bellied Swallow is not quite as abundant as the preceding species, and generally defers its visit in the spring a few clays later. Arriving in flocks, the majority soon pass on to other districts to breed, and return to us in August. In the latter part of the month they moult, and at this period is observed sitting in close bodies on fence rails and branches of trees, from which, owing to its feeble condition, it appears unwilling to move, except to supply the demands of appetite. On approaching quite near the resting-place, or when fired into, the 
congregated flock scatter in all directions, uttering sharp twittering notes. The nest, which is composed chiefly of dry grass and feathers, is usually placed in the hollow part of a tree. The eggs are pure white, and from four to six in number. It rears two broods in a season, and as soon as the young of the second brood have acquired sufficient strength to perform the journey, both young and old collect in large flocks and migrate southward.

\section{HIRUNDO RIPARIA-LINN.}

\section{BANK SWALLOW.}

Bank Swallow, or Sand Martin, Hirundo riparia, Wils, Amer. Orn.

Hirundo riparia, Bonap Syn.

Hirundo riparla, Sand Mertin, Sw \& Rich.

Bank Sivallow, or Sand Martin, Hirundo riparia, Nutt. Man.

Bank Swallow, or Saud Martin, Hirundo riparia, Aud. Orn. Biog.

Specific Character-Upper parts grayish-brown; fore part of the breast dusky; rest of the lower parts white; quills and tail feathers dusky; tail slightly forked. Length five inches, wing three and seven eighths.

This, the smallest of all our Swallows, is the first that visits us in the spring-arriving about a fortnight earlier than any of the other species. The Bank Swallow never accepts of the tenements provided by man, as do the more familiar Martin and Barn Swallow, but prefers taking up its residence in some steep bank, or in the vicinity of a stream of water-in the sand-hills on the beachand not unfrequently in the sides of the deep cuts excavated for the accommodation of rail-roads, in which it scratches out a hole two or three feet deep. The nest is formed of dry grass and feathers, and is placed at the extremity of the excavation. The greatest number of eggs which I have ever found in its nest was five, the color pure white. Sociable and friendly in their disposition, many select the same place to breed in, and when sporting around their dwellings, they swarm about the bank and keep up a constant twitter. Ornithologists pronounce it identical with the Bank Swallow of Europe; and according to Mr. Audubon, many pass the winter in Florida. 


\title{
HIRUNDO FULVA-VIEILL.
}

\section{CLIFF SWALLOW.}

\begin{abstract}
Fulvus or Cliff Swallow, Hirundo fulva, Bonap. Syn. Fulvus or Chiff Sivallow, Hirundo fulva, Nutt. Man. Republican or Cliff Swallow, Aud. Orn. Bıg.
\end{abstract}

Specific Character.-Forehead white; crown and a patch on the fore neck black; sides of the head, beneath the eye and sides of the neck deep brown-red. Adult with the forehead white, the lower part margined with a black band, which passes back to the eyes, meeting the black patch that occupies the whole upper part of the head; throat, sides of the neck, and a narrow band on the occiput deep brownish-red; a broad band on the hind neck grayish-brown, of which color are the fore part of the breast and sides of the bodythose parts being tinged with brownish-red, which color appears about the vent and on the lower tail coverts; on the fore neck a patch of black; abdomen grayish-wnite; back black, glossed with bluish; rump light reddish-brown; wings and tail feathers dusky brown. Length five inches and a half, wing four and seven eighths.

The appearance of this Swallow in the lower parts of the State of New York is quite recent. The first that I have known to have been observed in this vicinity, was shot at Manhattanville, in 1842, by Mr. Lawrence. In the month of June of the present year, a few specimens were seen in the suburbs of Brooklyn by Mr. Brasher, and in the latter part of August I met it at Gravesend. Previous to this year, I have no lnowledge of its occurring on Long Island; but I should not be surprised if even in a few years it were found quite common. On Long Island I am not aware that the Cliff Swallow has been known to breed; but Mr. Bell has informed me that he found its nest near his residence in Rockland County, in the month of May last-and according to his observations, it had not visited his section previous to the present year. 


\title{
F A M I L Y M U S C I C A P I N E.
}

\author{
FLYCATCHERS. \\ GENUS MUSCICAPA-LIN N.
}

FLYCATCHER.

[Bill of moderate length, stont, broad at the base-upper mandible inflected at tip, notched-long bristles at base; head rather large, upper part broad; neck short; wings rather long; tarsi about equal to the middle toe-slender ; fee: short, toes slerder, hind toe stronger.]

\section{MUSCICAPA TYRANNUS-LINN.}

\section{TYRANT FLYCATCHER.}

Tyrant Flycatcher, Muscicapa Tyrannus, Wils. Amer. Orn.

Muscicapa tyrannus, Bonap Syn.

King Bırd, or Tyrant Flycatcher, Muscicapa tyrannus, Nutt. Man.

Tyrant Flycatcher, Muscicapa tyrannus, Aud. Orn. Biog.

Specific Character-A concealed patch of bright vermilion on the crown; tail broadly tipped with white. Adult with the bill stout, blackish-brown; throat and upper portion of the fore neck white; sides of the body dusky, breast tinged with the same; rest of the lower parts white; head black, with a concealed patch of bright vermilion; upper parts bluish-gray, with the wings dark brown, the ends of the first two quills attenuated; the outer margins and tips of the primaries dull white, those of the secondaries more broadly marked with the same; tail brownish-black, broadly tipped with white, the outer webs of the outer feathers margined with the same. Female with the plumage duller, the lower parts more deeply tinged with dusky. Length eight inches and a quarter, wing four and a half.

The Tyrant Flycatcher, or "King Bird," is common with us, and is usually observed about the cultivated grounds. It arrives in May, and remains during summer. Its nest is generally found on the branch of an apple-tree; the eggs, five in number, are blotched and spotted with chocolate on white ground. The King Bird alights on the tops of small trees, stakes, or mullein stalks, which situation it at times occupies for minutes toge- 
ther. Many suppose it adopts this quiet attitude for the purpose of attracting passing insects, they mistaking the bright vermilion patch on the crown for a blossom, and in their eagerness to partake of the supposed nectar, the fatal error is not discovered un. til within reach of the beguiler's grasp. From the activity which we have seen it display when in pursuit of prey, we are inclined to the opinion that it is capable of supplying its wants without resorting to such stratagem. The King Bird seems particularly fond of bees, and provokes the farmer by the frequent visit it pays to the hive. Although not possessing musical talent, its bold, courageous bearing has rendered it noticeable. It is often seen amusing itself by attacking hawks and crows; and by its activity when on the wing, it manages to soar above the object of its sport, pouncing every few seconds on its quarry, until it becomes exhausted in the attack, when it retires to a convenient situation, uttering a shrill, triumphant twitter.

\section{MUSCICAPA ACADICA-GMEL.}

\section{SMALL GREEN-CRESTED FLYCATCHER.}

Small Green crested Fiycatcher, Muscicapa querula, Wils. Amer. Orn.

Small Pewee, Nutt. Man.

Muscirapa acadica, Bonap. Syn.

Small Green-crested Flycatcher, Muscicapa acadica, Aud. Orn. Biog.

Specific Character-Bill broad, the bands on the wings dull yellow; upper plumage duil greenish-olive. Adult with the upper parts deep greenish-olive; wings dark brown, the outer webs of the secondaries margined with pale yellowish-white, secondary and first row of smaller wing-coverts tipped with the same, forming two distinct bars on the wings; tail plain brown, the feathers margined externally with greenish; lower parts pale yellow, tinged with green; cye encircled with yellowish-white. Length five inches and a half, wing two and a half.

This species of Flycatcher is seldom seen except by those who are fond of strolling in the most secluded parts of the woods. In its habits it is solitary-generally seen on the lower branches of the largest trees-utters a quick, sharp note-arrives among us in the latter part of May, and retires southward early in September. 


\title{
MUSCICAPA CRINITA-LINN.
}

\author{
GREAT CRESTED FLYCATCHER.
}

\begin{abstract}
Great Crested Flycatcher, Muscical a crinita, Wils. Amer. Orn.
Muscicapa crinita, Bonap. Syn.

Great Crested Fiycatcher, Nutt. Man.

Great Crested Flycatcher, Muscicapa crinita, Aud. Orn. Biog.
\end{abstract}

Specific Character-Bill very strong; head crested; tail long, the feathers broad; the inner webs, except the middle pair, brownish red. Adult with the head crested, which with the plumage of the upper parts, is dull olive; wings brown, the outer webs of the primaries margined with rufus, those of the secondaries with dull yellowish-white-secondary coverts and first row of small coverts tipped with the same; tail long, the feathers rather broad, their inner webs reddish-brown, excepting the middle feather, which, with the outer webs of all, are plain brown; throat and fore neck grayish blue; rest of the lower parts and edges of the wings yellow.Female similar. Length eight inches and a half, wing four.

The Great Crested Flycatcher arrives among us about the middle of May, and dwells in the tops of the highest trees until the latter part of September, or early in October, according to the supply of its food, which consists chiefly of winged insects. Though remaining with us throughout the summer, it cannot be said to be very abundant at that season. It is usually observed in the woods among the heavy timber, and sometimes it resorts to the orchards. It is noted for its quarrelsome disposition, and loud and shrill voice, which is at all times audible above all the rest of our Flycatchers. 


\title{
MUSCICAPA FUSCA-GMEL.
}

\section{PEWEE FLYCATCHER.}

\author{
Pewit Flycatcher, Muscicapa nunciola, Wils. Amer. Orn. \\ Muscicapa fusca, Bonap. Syr. \\ Pewit Flycatcher, or Phœbe, Nutt. Man. \\ Pewee Flycatcher, Muscicapa fusca, Aud. Orn. Biog.
}

Specific Character-Both mandibles black their entire length; third quill longest, fourth scarcely shorter than the second; wings rounded; tail slightly emarginate. Adult with the head dusky upper parts tinged with dull olive; wings and tail plain brown; secondaries margined externally with dull white, their coverts tipped with the same-the outer margins of the lateral tail feathers of the same color; lower parts dull white, tinged with yellow; sides of the body and a portion of the breast tinged with dusky. Length six inches and three quarters, wing three and three-eighths.

Early in the month of March, the pleasing note of this familiar bird announces the approach of spring. Being one of our earliest visitants, its appearance is hailed with joy, as it is the harbinger of the rich gifts which Nature is about to bestow. A favorite place of the Pewee bird to construct its nest, is under the eaves of a deserted house or barn. It rears two broods in a season. The eggs, which are five in number, are white, slightly spotted with red. Late in the fall it retires southward. 


\title{
MUSCICAPA VIRENS-LINN.
}

\author{
WOOD PEWEE FLYCATCHER.
}

Wood Pewee, Muscicapa rapax, Wils. Amer. Orn.

Wood Pewee, Muscicapa virens, Nutt. Man.

Muscicapa virens, Bonap. Syn.

Wood Pewee, Muscicapa virens, Aud. Orn. Biog.

Specific Character-Upper mandible black; lower yellowish ; the base towards the point dusky; with the second quill longest; fourth about a quarter of an inch shorter than the second. Adult slightly crested; upper parts dark olive, darkest on the upper part of the head; two bands on the wings formed by the tips of the secondary coverts and first row of small coverts, which are dull white; wings and tail dark brown; throat and breast cinereus, tinged with green-rest of the lower parts greenish-yellow; tail emarginate; at all times distinguishable from the preceding by the color of the lower mandible. Length six inches and a quarter, wing three and three-eighths.

The Wood Pewee is very nearly allied to the former in plumage, but differs materially in its note and habits. The former is one of our most early visitants, while the present defers its visits until late in May. It frequents the shady parts of woods, and watches its insect prey from the high, dead branches. Its note is more prolonged than the former-and although not musical, it continues to enliven the forest after nearly all our songsters have become silent. 


\section{MUSCICAPA PUSILLA-SWAINSON}

\section{LEAST PEWEE.}

Tyranula pusilla, Litıle Tyrant Flycatcher, Sw. \& Rich. Little Tyrant Flycaicher, Muscicapa pusilla, Aud. Little Pewee, Nutt. Man.

Specific Character-Bill shorter and narrower than M. acadica; the bands on the wings dull white; third and fourth primaries equal, longer than the second; first shorter than the sixth. Adult with loral band, ring surrounding the eye, tips of first row of small, and secondary coverts, and the margins of the secondaries, dull white, those markings in $M$. acadica are dull yellow; upper parts dull olive brown, slightly tinged with green on the back; fore neck and fore part of the breast ash gray; sides of the body much darker; abdomen and the middle of the lower part of the breast pale yellow; lateral feathers pale brownish-gray. Length five inches, wing two and three-eighths.

This not abundant species I have met with on various parts of Long Island; in the month of June, in company with my friend Phillip Brasher, we obtained two specimens in the woods near Gowannus. I also shot one at Huntington South, and one other between East Hampton and Sag Harbor. The second I mot with about the middle of August-the latter in the early part of September-and I do not think it improbable that a few breed here, though I have never found its nest. It seems to prefer the woods, is an active, lively bird, and utters a rather loud and quick noteIt is nearly allied to the Small Green Crested Flycatcher, [M. acadica,] from which it can at all time be distinguished by the form of the bill. 


\title{
MUSCICAPA RUTICILLA-LINN.
}

\author{
AMERICAN REDSTART.
}

\begin{abstract}
American Redstart, Muscicapa ruticilla, Wils. Amer. Orn. Muscicapa Ruticilla, Bonap. Svn.

American Redstart, Muscicapa ruticilla, Aud. Amer. Orn.

American Redstart, Muscicapa ruticilla, Nutt. Man.
\end{abstract}

Specific Character-Basal half of wings three fourths the length of tail; sides of the body bright reddish orange. Adult with head, neck all round, back, fore part of the breast, the wing and upper tail coverts black; primaries and secondaries commencing at the base, orange-red, which color extends midway the length of the wings, rest part blackish-brown, terminal portion of the tail feathers also black; the rest part same as basal half of the wings, excepting the middle pair of feathers, which have the entire length of their inner webs the same color as the tips; sides of body and lower wing coverts bright reddish-orange; rest of the lower parts white. Female, with the upper parts yellowish-brown; the markings on the wings, tail, sides of the breast, and lower wing coverts yellow.Length five inches, wing two and five-eighths.

This most beautiful of all our Flycatchers, is distributed over the Union. It is common in the woods and along the road-side, as well as in the swamps and meadows; indeed, wherever its insect prey abounds, this active bird is seen, mounting to the tops of the highest trees, or darting rapidly through the low underbrush, uttering as it passes from twig to twig a sprightly twitter. It usually builds its nest in a low bush or sapling, and deposites four or five white eggs, speckled with gray and dotted with black. It arrives among us in the latter part of April, and returns southward late in September. 


\title{
GENUS CULICIVORA-SWAINSON.
}

\author{
GNAT CATCHER.
}

[Bill of moderate length, slender, depressed at base, narrowing towards the end ; upper mandible notched at tip, general form very slender; tail long, much rounded.]

\section{CULICIVORA CERULEA-LATHAM.}

\section{BLUE-GRAY GNAT CATCHER.}

Blce-gray Flycalcher, Muscicapa cœrulea, Wils. Amer, Orn.

Sylvia cœrulea, Boisap. Syn.

Blue-gray Sylvan Flycatcher, Muscicapa cœrulea, Nutt. Man.

Blue-gray Flycatcher, Muscicapa cœrula, Aud. Orn. Bıg.

Specific Character-Bill rather long, very slender towards the end; upper parts blue; beneath grayish-white. Adult with the upper parts light blue, deeper on the head, approaching to gray on the tail coverts; tail long and rounded, the feathers narrow; wings brown, tail darker, the larger portion of the outer two feathers white, the third margined externally and tipped with the same-the rest plain, with the middle pair of feathers a shade lighter; lower parts grayish-white; a white ring round the eye; a narrow black band on the forehead passing over the eyes. Length four inches and a half, wing two. Female with the plumage duller, and without the black band on the head.

This, the smallest of our Flycatchers, is surpassed by none in activity. It is continually on the watch for passing insects, which it pursues among the high branches. With us it is a scarce species -in the Southern States more abundant.

Its nest was found in Maryland, on the branch of a "Yokewood" tree, by Mr. Bell, who has informed me that it was constructed sim. ilarly to that of the Humming Bird, but much larger. 


\section{F A M I L Y S Y L V I C O L I N}

WOOD WARBLERS.

\section{GENUS MYIDIOCTES-LATHA M.}

FLYCATCHING WARBLER.

[Bill of moderate lengih, broader than high at base, straight, rather stout- -8 slight notch at tip; head ovate ; general form slender; tail rather long, and slightly rounded.]

\section{MYIODIOCTES MITRATUS-LATHAM.}

\section{HOODED FLYCATCHING WARBLER.}

Muscicapa cucullata, Wils. Amer. Orn.

Sylvia mitrata, Bonap. Syn.

Mitred Sylvan Flycatcher, Nutt. Man.

Hooded Warbler, Sylvia mitrata, Aud. Orn. Biog.

Specific Character-Male with the fore part and sides of the head yellow; throat, neck all round, and hind head black. Female with the yellow on the head faintly developed, and but a slight trace of the black markings so conspicuous in the male. Adlult with the forehead and sides of the body rich yellow; neck all round, and upper portion of the neck, black; rest of the lower parts yellow; upper plumage yellowish-olive; wings and tail brown, the feathers margined with the same color as the back; the larger portion of the inner web of the outer tail feather white, decreasing on the second and third tail feather; tail emarginate. Female with the yellow markings on the head much fainter; throat, fore neck, and all the lower parts yellow, with a few touches of dusky on the lower portion of the fore neck; a few spots of the same color on the hind head; upper plumage similar to the male. Length of five inches and a half, wing two and five. eighths.

Naturalists have divided this family [Sylvicolina] into five genera, which classification we find has its opponents, on the score of 
its incumbering the pursuit with unnecessary and perplexing no. menclature. As for ourselves, in such arrangement we cheer: fully acquiesce, viewing it as a system founded on a thorough acquaintance with the science-one which is calculated to reduce the labor of the student. In many cases with immature birds, as is also the case in certain stages of the adult, there are no signs of plumage by which the species can be identified. In such cases of doubt, by referring to the generic character, which always remain unchanged, you are at once brought to the class to which it belongs, thus affording a greater facility for arriving at the species.

Such species of this numerous Family as visit Long Island, are mostly birds of passage. They arrive among us during the month of May, early or late, according to the weather. Their visit in the spring is of short duration, soon passing on farther North to breed. When journeying southward, they return to us in autumn, which gives us an opportunity to secure both the adult and young. Although not affording amusement to sportsmen, they are nevertheless rendered attractive by their beautiful plumage and musical notes. They frequent the fields and woods, and in spring the blooming orchards echo with the sweet notes of these sprightly minstrels. At times, several species are observed col. lecting food, or sporting around the same tree; unless to a close observer, their manners and customs appear quite similar.

With us, the Hooded Flycatching Warbler is not abundant. In the Southern and Western States it is more common; it is generally met with in low situations; feeds on winged insects; and its note is loud, lively, and agreeable.

With the practical Ornithologist, a minute description of the habits of familiar species is not required. Those who have never parti. cipated in the pleasures of a collecting tour, and who are desirous for a more detailed account, will of course refer to the highly celebrated works of Wilson and Audubon. 


\section{MYIODIOCTES CANADENSIS-LINN.}

\section{SPOTTED CANADIAN FLYCATCHING WARBLER.}

Canada Flycatcher, Muscieapa canadensis, Wils. Amer. Orn.

Sylvia pardalma, Bonap. Syu.

Canada Warbler, Nuti. Man.

Caneda Fiycalcher, Muscicapa canadensis, Aud. Orn. Biog.

Specific Character-Third quill longess, scarcely longer than the second, which is about one-twelfth of an inch longer than the first, the fourth slightly shorter than the second; fore part of breast with oblong spots of black. Adult male with the upper parts bluish gray ; at the base of the upper mandible a band of yellow; a ring of the same color round the eye ; upper part of the head spotted with black; wings and tail plain brown, the latter rounded; throat and lower parts bright yellow; a spot of black below the eye which continues down the sides of the neck and unites with oblong spots of black on the fore part of the breast; lower tail coverts white. Female with the general plumage duller, and the black markings on the breast fainily developed. Length of male five inches, wing two and five-eighths.

In its migratory course this species visits Long Island. Like most of the species, at some seasons, during spring, it is quite plentiful ; and again at other times occurs only in small numbers. Mr. Audubon found it breeding in the Great Pine Forest, Pennsylvania, and met with it in Maine, New Brunswick, Nova Scotia, and Labrador. It flies swiftly, utters an agreeable note, and inhabits generally the woodlands.

\section{MYIODIOCTES FORMOSA-WILSON.}

\section{KENTUCKY FLYCA'TCHING WARBLER.}

Kentucky Warbler, Sylvia formosa, Wils. Amer. Orn.

Sylvia formosa, Bonap. Syn.

Kentucky Warbler, Sylva formosa, Aud. Orn. Biog.

Kentucky Warbler, Nutt. Man.

Specific Character-Bill rounded, narrower at the base than any of this genus; bristles slight; second quills longest; first and third about equal; tail slightly emarginate, nearly even; upper parts olive-green; lower parts bright yellow. Adult male with the up- 
per parts olive-green; line over the eye, curving behind it and whole lower parts rich yellow; upper part of head black, towards the hind part spotted with lighi ash; lores and a spot curring down the necli also black; tail nearly cren at the end, and of a rich olive green; legs pale flesh color. Female with the greater part of the crown yellow, and black under the eye wanting. Length five inches and a half, wing two and six-eighths.

The discovery of this species is due to Wilson, who first met with it in the State of Kentucky; he also found it numerous in the State of Tennessee, and met with it in all the intermediate districts between Nashrille and New Orleans. It frequents low, damp woods, and builds its nest in the middle of a thick tuft of rank grass, sometimes on the ground. The materials are loose, dry grass, mixed with the light pith of weeds, and lined with hair. The female lays four, and sometimes six eggs-pure white sprinkled with specks of reddish, on which she was observed by Wilson sitting in the early part of May.

In the State of Maryland, during spring, the Kentucliy Warbler is also common. In Anne Arundel County, Mr. Bell procured upwards of fifty specimens in the course of a few days' shooting. In the State of New York it is rarely seen, A few have been shot in Rockland County, and at Hobolien, N. J. The specimen in my possession was shot in the roods at Raynor South,and a few others have been procured in the same section. On no other part of the Island have I observed it, and I consider it with us a very searce species.

In plumage, it is not unlike the Maryland Yellow-throat-and like that species prefers the low bushes; its note is rather loud, clear and distinct. Iis habits are those of a Warbler, and in point of Genera it is more closely allied to Sylvia than Muscicapa. 


\section{MYIODIOCTES WILSONII-BONAP.}

\section{WILSON'S FLYCATCHING WARBLER.}

Green Black-capned Flycatcher, Muscicapa pusilla, Wils. Amer. Orn.

Silva Wilsonii, Bonap. Syn.

Green Black-capped Warbler, Nint. Man.

Green Black-capped Flycatcher, Muscicapa Wilsonii, Aud. Orn. Biog.

Specfic Character-Crown black; upper parts green, tinged with yellow; form slender; tail rather long. Adutt with the crown glossy, bluish-black, bordered in front and at the sides wilh yellow; occiput yellowish-green, hind neck and back the same; wings and tail plain brown; the feathers edged with greenish; lower part yellow. Fonale similar, with less black on the crown. Lenuth four inches and a lalf, wing two and one quarter.

In this ricinity the Green Black-capped Flycatcher is rarely seen. In the Southern States it is said to be more abundant; it prefers low, swampy situations, is an expert flycatcher, and utters a sharp note.

\section{GENUSSYLVICOLA-SWAINSON.}

\section{IVOOD IVAIBBLERS.}

[Bill short, broader than high at base, straight, rather strong, tapering-nostrils oval, parly concealed by feathers ; head of noderate size, neck short body rather slender; wings of moderate length; lail rather long. emarginate ; larsi longer than the middle toe; feet and toes stender, inner toe free; claws arched, acute.]

\section{SYLVICOLA PINUS-LATHAM.}

\section{PINE-CREEPING WOOD WARBLER.}

Sylvia pinus, Wils. Amer. Orn.

Sylvia pinus, Bonap Syn.

Pine Watbler, Sulvia piuua, Nutt. Man.

Pine Creeping Waruler, Silvia pinus, Aud. Orn. Biog

Specific Character--Second and third quills equal; fourth slightly longer than the first; tail emarginate. Adult male with the upper parts bright olive; wings and tail feathers brown; secondary coverts and first row of small coverts tipped with dull white-a similar patch on the inner webs of the outer two tail-feathers; lower parts yellowish-green. Female, with the upper parts dull olivaceous brown; throat, fore neck, and fore part of the breast, pale yellowish green-rest of the lower parts dull white, faintly tinged with yellow. Length five inches and a quarter, wing two and seven-eighths. 
The Pine-creeping Warbler-so called from its habit of creeping up the trunks of pine-trees in search of the larræ of insects--is quite a common species, and one of the first that arrives in the spring. On Long Island it breeds; the eggs, four in number, are white, marked at the great end with dark brown. It utters a simple chirrup, and is generally found in the pine forests. Common in various parts of the Union.

\section{SYLVICOLA DISCOLOR-VIEILL.}

\section{PRAIRIE WOOD WARBIER.}

Prairie IVar'lar, Sylvia minut , W Wls. Amrr. Orn.

Sylvia discolor, Bonap. Syn.

Prairie Warber Sulva discolor, Nutt. Man.

Prairie Warbler, Sulvia discolor, And. Orı Biog.

Specific Character-Bill slender; tarsi slender, very much compressed; second quill longest; first and third about equal ; fore part of back distinctly marked with reddish-brown; the sides of the body streaked with blacli. Adult male with the upper parts olivaceous, marked with reddish-brown on the back; the head bordered in front and over the eyes with yellow; a line of black fiom the bill to the eye, a similar spot behind the eye; cheeks next to eye yellow, lower portion black; a spot of black on the sides of the neck; lower plumage bright yellow; the sides of the body broadly streaked with black; first row of lesser wing corerts tipped wih yellow; secondary coverts more faintly marked with the same; wings and tail blackish-brown, a large portion of the outer featiers white, the next with a similar spot on the inner web towards the end, the third with a smaller syot of the some color. Female with the plumage duller, and the black marks on the sides of the head wanting: Length four inches and three-quarters, wing two and three-eighths.

This delicate and prettily-marked species prefors the neglected fields and open plains. The most of its time is passed upon the ground, searching among the leaves, or climbing up the stallis of rank weeds in pursuit of insects. Its flight is short and feeble; it utters a low note. It remains with us during the summer, constructs its nest, which is small and neatly made, in the low bushes, sometines on the lower branches of the pine tree, eggs four, spotted with brown on white ground. 


\title{
SYLVICOLA STRIATA-LATHAM.
}

\author{
BLACK-POLI, WOOD WARBLER.
}

Black-poil Warbler, Sylvia striata, Wils. Amer, ()rn.

Sylvia striata, Boriap Syn.

Sylvicola striata, Black poll Warbler, Sw. \& Rich.

Black-poll Warbler, Sylvia striata, Nuit. Man.

Black-poll Warbler, Sylvia striata, Aud. Orn Biog.

Specific Character-Second quill scarcely longer than the first, which is longer than the third; upper mandible black; lower dull white, at base, sides and toward the point dusky. Adult male with the upper part of the head black; sides of the head below the eyes, throat, fore neck, middle portion of the breast, abdomen, lower tail coverts, and a few feathers on the occiput, white; back bluish ash-gray, streaked with black, as are the sides of the body; quills and tail feathers dark brown; primaries edged with greenish-yellow; secondary coverts and first row of small coverts broadly tipped with white, forming two distinct bands on the wings; outer three tail feathers with a patch of white on their inner webs near the end, much reduced on the third feather. Female with the head and upper paits dull green, streaked with dusky; cheeks and fore neck yellowish-gray; lower parts dull white, tinged with yellow; wing bands tinged with yellow. Young similar. Length five inches and a quarter, wing three.

The Black-poll Warbler is the last of its tribe that arrives among us in the spring. This may be owing to its feeding on winged insects, which are not brought into animation, or do not abound in its favorite haunts until invited by the potent influence of the sun. The same cause operating in the Fall, it is about the first to bid farewell, following its insect prey to a warmer climate. It has a single, low, unmusical note.

\section{SYLVICOLA BLACKBURNIE-LATHAM.}

\section{BLACKBURNIAN WOOD WARBLER.}

Blackburnian Warbler, Sylria Blackburniae, Wils. Amer. Orn.

Sylvia Blacliburnae, Bonap Sin.

Blackburnian Warbler, Sylvia Blackburniae, Nutt. Man.

Blackburnian Warbler, Sylyia Blackburnae, Aud. Orn. Biog.

Specific Character-Throat, fore neck, bands on the upper part and sides of the head, and the sides of the neck, bright orange-red. 
Female with similarly formed marking but much paler. Adult male, with a band of orange-yellow commencing at the nostrils, passing over the eye on the hind neck, meeting a patch of the same color on the sicles of the neck; a spot under the eye orange yellow; a short band of the same color on the crown and a patch behind the eye black, of which color are the upper part of the hearl, nape, and back, the latter marked with white-a similar patch on the wings; quills and tail feaihers dark brown; larger portion of the lateral feathers on either side white, diminishing on the second and reduced to a small spot on the third; throat, fore neck, and fore part of the breast ricb orange; on the siles of neck an irregular black band; sides of the body streaked with black; rest of the lower parts dull yellow. Female with the upper parts dull green, strealied with black; throat and fore neck yellow, slightly tinged with orange-red; the bands on the upper part and sides of the head and neck pale yellow. Length four inches and three quarters, wing two and three quarters.

This rather scarce species is one of the most beautiful which adorns our woods. In the spring, its rich plumage appearing among the trees, delights the eye of the traveller; and its agreeable note, mingling with others of its tribe is a great acquisition to the rich melody of the forest. On Long Island I have not found it plentiful, a few are observerl during spring and antumn. In Massachusetts, near Williamstown, Mr. W. C. Edwards informs me that he has met with them in considerable numbers.

\section{SYLVICOLA MACULOSA-LATHAM.}

\section{BLUE-HEADED YELLOW-RUMPED WOOD WARBLER.}

Black and Yellow Warbler. Sylvia magnolia, Wils. Amer. Orn

Sivida maculosa, Bmap. Syu.

Black and Yellow Warluer, Silvia maculo:a, Niut Man.

Sivlva maculosa, Velton-rum, Warbler, Sw \& Rich.

Black ant Yellow Warbler, Sylva maculosa, Aud. O;n. Bing.

Specific Character.-A black band on the fore part and sides of the licad; rump yellow; the inner webs of all the tail feath. 
ers, excepting the middle pair, with large white spots. Adult male with the head bluish, bordered in front with black; loral space, cheeks, hind neck, and fore part of the back of the same color, rest part of the back grayish-blue, tinged with olive; rump yellow; upper tail coverts and tail black; the inner webs of the tail feathers about two thirds their length from the base are largely spotted with white, excepting the middle pair, which are plain; wings dark brown, secondary and first row of smaller coverts margined and broadly tipped with white: throat pure yellow; lower parts bright yeleow, breast and sides marked with long spots of black; under tail coverts white; eyelids white, with a band of the same color behind the eve. Female with the plumage duller. Length four inches and three quarters, wing two and one quarter.

This beautiful bird adorns the fields and orchards, and enlivens the woods with its agreeable song. During some seasons, scarcely a specimen is observed on Long Island; again, it occurs in considerable numbers. I have met it in various localitics; its notes, though rather feeble, are soft and musical. With us it is a bird of passage - arrives in the month of May, and passes on to breed. Like many of our warblers, it is fonnd during the breeding season at the White Mountains, New Hampshire.

\section{SYLVICOLA CORONATA-LATHAM.}

\section{YELLOW.CROWNED WOOD WARBLER.}

Yellow-rump Warbler, Srlvia coronata, Wils Amer. Orn.

Sylvia coronata, B.nap. Syr.

Yellow-crowned Warbler, or Myrtle B rd, Sylsia coronata, Nutt. Man.

Yellow-rump Warbler Sylvia coronala, Aud. ()rn. Bug.

Specific Character-Crown, rump, and a large patch on the sides, of the body bright yellow. Adult male, cheeks and a line before the eye black; lower eyelid and a line over the eye white; crown, rump, and a large patch on the sides of the bedy bright yellow; upper parts deep ash-gray, streaked with black; secondary coverts and first row of small coverts tipped and edged with white; tail feathers dark brown, the outer three with a patch of white on their inner webs near the ends; throat white; lower portion of the fore 
neck black, which color predominates on the breast; abdomer white; flanks streaked with dusky. Female with the yellow spot on the crown faintly dereloped; the yellow markings on the rump and sides of the body much palex.

Length five inches, wing two and three quarters.

This abundant species remains with us long after all the rest of its tribe have gone to their winter quarters. Late in autumn, in compa. ny with the Red-breasted Thrust or Robin, it frequents the cedartrees, the berries of which at this season, form the principal portion of its food. At this period the plumage of the male is similar to that of the female.

\section{SYLVICOLA CANADENSIS-LINN.}

\section{BLACK-THROATED BLUE WOOD WARBLER.}

Black-throated Blue Warbler Sylvia canadensis, Wils. Amer. Orn.

Sylvia canadensis, Bonap. Syn.

Black-throated Blue Warbler, Syliia canadensis, Nutt. Man.

Black-throated Blue Warbler, Sylvia canadensis, Aud. Orn. Biog.

Specific Character-Second and third quills about equal, fourth scarcely shorter, first longer than the fifth; tail rounded, outer three feathers spotted with white, the rest plain margined externally with blue. Adult with a black band on the forehead; cheeks, throat, fore neck, and sides of the body also black, rest of the lower parts white; upper parts dull blue; wings and tail blackish-brown-the quills towards their base white, forming a conspicuous patch on the wings; outer three tail feathers with a patch of white on their inner webs near the ends; primary and tail feathers margined with blue. Female, upper plumage green ish olive, the basal part of feathers blue, lower parts dull yellow; the white markings on the wings and tail less conspicuous. Young similar, with a dull white line from the nostrils to the eyes. Length five inches, wing two and five-eighths.

The Black-throated Blue Warbler takes up its residence in the woods convenient to stagnant pools or shallow streams that abound with winged insects, which constitutes the larger portion of its food. At times it is seen moving along the lower branches, or searching among the moss on the trunks of trees, for various species of insects. Its nest I have never found. It arrives in the latter end of April 
or beginning of May-spends a few days in the deepest parts of the woods-and then passes on to its breeding quarters. In pursuing its prey it displays a good deal of activity; it utters an unmusical note; is a strongly-marked species; with us does not occur in large numbers.

One of the first specimens that I ever saw, I observed in a garden in the city of New York, in the month of May last; it alighted on a lilac bush, appeared very tame, and allowed me to approach so near, that for a moment $I$ entertained the idea of capturing it alive; while attempting it, it flew off to a neighboring Catalpa, and $I$ lost sight of it.

\author{
SYLVICOLA VIRENS-LATHAM. \\ BLACK-THROATED GREEN WOOD WARBLER \\ Sylvia virens, Wils. Amer. Orn. \\ Sylvia Virens, Bonap. Syn. \\ Black-throated Green Warbler, Nutt. Man. \\ Black-throated Green Warbler, Sylvia virens, Aud. Orn. Biog.
}

Specific Character-Forepart and sides of the head and sides of neck yellow; throat and fore neck black; upper parts yellowish-green. Adult male with fore part and sides of the head and sides of neck yellow; upper parts light yellowish-green; wings and tail browntwo white bands on the former; a large portion of the outer two tail feathers white, the third with a patch of the same color on the inner web toward the end; throat, fore part of the neck and sides of the breast black, that color continuing in longish spots on the sides of the body; rest of the lower paris white, slightly tinged with yellow. Female with the throat yellowish-white; a dusky band on the sides of the neck, fore part of breast and sides of the body dusky; upper parts the same as the male, with the plumage duller. Length four inches and three quarters, wing two inches and a half.

The Black-throated Green Warbler is another of those lively inhabitants of the roods that spend a short time with us in the spring. It is generally seen on the upper branches in search of the larvæ of insects. In the fall its chirping notes are again heard as it passes on to the South. 


\title{
SYLVICOLA ESTIVA-GMEL
}

\author{
YELLOW-POLL WOOD WARBLER.
}

Blue-eyed Warbler, Sylvia citrinella, Wils. Amer. Orn.

Sylvia aestiva, Bonap. Syn.

Summer Yellow Bird or Warbler. Nutt. Man.

Yellow-poll Warbler, Sylvia aestiva, Aud, Orn. Biog.

Specific Character-Upper parts yellowish-green; lower parts bright yellow, streaked with brownish red. Adult male with fore part of head, cheeks, throat, sides of the neck, and lower parts pure yellow; breast and sides of the body streaked with reddish-brown; upper parts pale yellowish-green; wings brown, the primaries mar. gined with green, the secondaries and their corerts with yellow; tail feathers brown, with the greater portion of their inner webs yellow. Female with the colors duller; lower parts faintly streaked with reddish brown, which color is wanting in the young. Length four inches and three quarters, wing two and a quarter.

This species is familiarly known by the name of Summer or False Yellow Bird. It is one of our earlest visitors in the spring and remains with us throughout the summer. As a vocalist, it has no claims to our attention-still it is universaily admired on account of its sprightly manners, sociable disposition, neat, rich attire, and general pleasing appearance.

Its usual employment is hunting for small caterpillers among the slrubbery and fruit trees, and it is observed pursuing the same occu. pation in the woods; but its favorite resort seems to be the willows, cspecially those which overhang a shallow brook, or occupy moist situations on a mill stream. The nest is usually placed on some low bush; the materials used for its construction are dry grasses; sometimes woven together with tow, or slender strips of the flexible bark of the willow, selecting the softer and silken parts of plants, or hair, for finishing the interior. The eggs, four-sometimes five, are of a dull white color, finely dotted near the larger end with palebrown. 


\title{
SYLVICOLA PETECHIA-LATHAM.
}

\section{YELLOW RED-POLL WOOD WARBLER.}

\begin{abstract}
Yellow Red-poll Warbler, Sylvia petechia, Wils. Amer. Orn.
Sylvia petechia, Bonap. Syn.

Sylvicola petechia, Yellow Red-poll Warbler, Sw. \& Rich.

Yellow Red-poll Warbler, Sylvia petechia, Nutt. Man.

Yellow Red-poll Warbler, Sylvia petechia, Aud. Orn. Biog.
\end{abstract}

Specific Character.-Second and third quills about equal; the first slightly shorter than the fourth; tail emarginates the inner webs of the outer two feathers toward the end, largely spotted with white; crown brownish-red. Adult with a yellow line from the nostrii over the eye; crown deep brownish-red; sides of the head and upper parts yellowish-olive, streaked with brown; rump greenish-yellow; quills and tail feathers dark brown, the primaries edged with brownish-white, the tail feathers margined with greenish-yellow, the inner webs of the outer two with a white patch near the end; lower part yellow, streaked with reddish brown, which color is deeper on the sides of the body; lower tail coverts plain yellow. Female with the tints duller, especially on the crown, which has but a slight resemblance to that of the male. Length five inches, wing two and five-twelfths.

The favorite resort of this species is among the low thickets. It is fond of watching its insect prey from the Black Alder, and when not in pursuit of food it appears restless, spreading its wings and tail, and uttering an unmusical note. With us, it is not a summer resident, nor have $I$ at any season found it abundant. 


\section{SYLVICOLA AMERICANA-LATHAM.}

\section{BLUE YELLOW-BACKED WOOD WARBLER.}

Blue Yellow-back Warbler, Sylvia pusilla, Wils. Amer. Orn. Sylvia Americana, Bonap. Syn.

Particolored $W^{*}$ arbler or Finch Creeper, Nutt, Man.

Blue Yellow-backed Warbler, Sylvia Americana, Aud. Orn. Biog.

Specific Character-Upper parts blue; a broad deep olive band on the fore part of the back.

Adult with the loral space black; head, sides of the neck, and all the upper parts blue, marked with deep olive on the back; wings and tail blackish brown, edged with blue; two bands across the wings formed by the tips of the outer secondary coverts, and those of the first rows of small coverts, which are white; the outer three tail feathers with a spot of white on their inner webs near the end; throat yellow; a black band on the fore neck, below which a belt of dull orange; fore part of the breast yellow; side of the body paleblue, marked with a few touches of reddish-brown; rest of the lower parts white.

Female, with the loral band and the belt on the fore neck wanting. General plumage duller.

Length four inches and a quarter, wing two inches and a quarter.

This abundant species seems to have no choice of residence-it is equally common in the woods, high, dry grounds, and swamps, and resorts to the orchards, where it is seen searching among the blossoms for insects, and it is observed on the uppermost branches of the tallest trees. It has a low, feeble, chirping note. On Long Island I am not aware that it breeds, but I am informed that its nest has been found at the Catskill Mountains. 


\title{
SYLVICOLA MARTIMA-WILSON.
}

\author{
CAPE MAY WOOD WARBLER.
}

Cape May Warbler, Sylvin martima, Wils. Amer. Orn.

Sylvia martima, Bonap. Syn.

Cape May Warbler, Sylvia martima, Nutt. Man.

Cape May Wabler, Sylvia martima, Aud. Orn. Biog.

Specijic Character-Second and third quills about equal and lon. ger; first longer than the fourth; sides of the head reddish-yellow; throat, a band on the sides of the neck, rump and lower parts yel. low, the latter streaked with black. Adult with the upper part of the head dusky; sides of the head reddish-yellow; throat and a band on the neck nearly meeting on the hind neck, light yellow, as are the fore part of the neck and breast-which, with the sides of the body, are streaked with dusky; abdomen white; tinged with yellow; rump bright yellow; back yellowish-olive, streaked with dusky; wings and tail brown, the feathers margined externally with greenish; a white band on the wing, formed by the outer edges and tips of wing coverts; a patch of white on the inner webs of the outer three tail feathers. This description is taken from a specimen which I received through the politeness of S. F. Baird, Carlile, Pennsylvania. Length four inches and eleven-twelfths, wing two and five-eighths.

On Long Island the Cape May Warbler is exceedingly rare. I know of but one speeimen having been proeured here. The cabinet of Mr. Lawrence contains a specimen shot on New York lsland by Mr. Bell-which, with one other specimen procured by him at Hoboken, are all that I know to have occurred in the vicinity of N. Y. In Pennsylvania I am informed by S. F. Baird, that a few are seen every season. It is a beautiful and strongly marked species -but from never having met with it during my rambles, from my own observations I know nothing of its habits and notes. 


\title{
SYLVICOLA CASTANEA-WILSON.
}

\author{
BAY-BREASTED WOOD WARBLER.
}

Bay-breasted Warbler, Sylvia castanea, Wils. Amer. Orn.

Sylvia castanea, Bonap. Syn.

Bay-breasted Warbler, Sylvia castanea, Nutt. Man.

Bay-breasted Warbler, Sylvia castanea, Aud. Orn. Biog.

Specific Character-Second quill longest; first and third scarcely shorter and about equal; upper part of the head, fore neck and sides of the body chestnut-red. Adult with the forehead, loral space and cheeks black; crown, fore neck, a portion of the breast, and sides of the body chesnut-red, deeper on the crown; a patch of yellowish white on the sides of the neck; back bluish, ash-gray, streaked with black; two white bands on the wings; quills and tail feathers brownish-black, the outer three of the latter with a patch of white on the inner webs; abdomen and middle portion of the breast white. Female, with the markings on the upper part of the head and sides of the body lighter.. Young in Autumn with the head and upper parts yellowish-green, streaked with dusky; throat and fore neck faintly tinged with bay-sides of the body more deeply tinged with the same. Length five inches, wing two and three-eighths.

The Bay-breasted Warbler is among the last of the Genus that arrives among us in spring. During some seasons it occurs in considerable numbers, but in general it is by no means plentiful. It seldom alights on the ground, or low bushes. It frequents the orchards, but is more usually observed on the middle or upper branches of the forest trees. In pursuit of its insect prey it displays much less activity than many other species of Sylvia, and is noted by collectors for its unsprightly manner. 


\title{
SYLVICOLA ICTEROCEPHALA.
}

\author{
CHESTNUT-SIDED WOOD WARBLER
}

Chestnut-sided Warbler, Sylvia icterocephala, Wils. Amer. Orn.

Sylvia ucterocephala, Bonap. Syn.

Chestnut-sided Warbler, Sylvia icterocephala, Nutt. Man.

Chestnut-sided Warbler, Sylvia icterocephala, Aud. Orn. Biog.

Specific Character-Upper part of the head light yellow; along the sides of the body a broad, bright chestnut band. Adult with the upper part of the head light yellow ; upper parts blvish-grey, rather deeply tinged with greenish-yellow; the back broadly streaked with black; wings and tail brown; secondary coverts and first row of small coverts tipped with pale yellow; outer three tail feathers with a patch of white on the inner webs near the end; behind the eye a large patch of white; a black band on the sides of the throat uniting with a broad band of chestnut that passes down the sides of the neck and body ; fore neck, breast, and abdomen white, the latter tinged with yellow. Female with the upper part of the head tinged with green, and the chestnut band extending scarcely beyond the breast. Length five inches, wing two and a half.

This species, more beautiful than the former, is another of those migrative birds that only appear among us during spring and the early part of autumn. It has nothing in particular to recommend it. self to our notice other than its handsome markings, which vie with the gayest of our Sylvias. It inhabits similar situations with the preceding, and displays much greater activity when darting about in pursuit of its favorite insects. It has no song other than a few feeble chirping notes, and with us is rather more plentiful than the former. 


\title{
GENUS TRICHAS-SWAINSON.
}

\author{
GROUND WARBLER.
}

[In this Genus the bill is slightly decurved-the tail rounded, always plain, or without spots; in other respects similar to the preceding.]

\section{TRICHAS MARYLANDICA-LINN.}

\section{MARYLAND GROUND WARBLER.}

Maryland Yellow-throat, Sylvia Marilandica, Wils. Amer. Orn.

Sylvia Marylandica, Bonap. Syn.

Maryland Yellow-throat, Nutt. Man.

Yellow-breasted Warbler, or Maryland Yellow-throat, Sylvia

Trichas, Aud. Orn. Biog.

Specific Character-Third and fourth quills equal and longest; second next in length; fifth longer than the first; wings rather short; tail rounded; upper parts yellowish-green; throat, fore neck, and fore part of the breast yellow. Adult with the forehead, loral space, and sides of the head black, bordered with pale bluish-white; upper parts yellowish-green, with a slight tinge of red on the crown; quills and tail feathers brown, margined with yellowish-green; throat, fore part of the neck and breast, edges of the wings, and lower tail-coverts, bright yellow; rest of the lower parts tinged with yellow. Female with the general plu. mage duller; the black and bluish-white bands on the head and sides of the neck wanting. Length of male four inches and three quarters, wing two and a quarter.

This sociable and prettily-marked species is one of our most common warblers, and is found in all parts of the United States. It inhabits low, swampy grounds, passing its time arnong the small bushes and briars, suffering itself to be nearly approached without exciting suspicion. When alarmed, it merely flies to a neighboring bush, and recommences its simple song as if nothing had occurred to disturb it. It arrives among us in the early part of May-builds its nest on the ground among the briars-deposites five white eggs, speckled with reddish-brown-and retires southward early in the month of September. 


\title{
TRICHAS PHILADELPHIA-WILSON
}

\section{MOURNING GROUND WARBLER.}

\author{
Mourning Warbler, Sylvia Philadelphia, Wils. Amer Orn. \\ Sylvia Philadelphia, Bonap. Syn. \\ Mourning Warbler, Sylvia Philadelphia, Nutt. Man. \\ Mourning Warbler, Sylvia Philadelphia, Aud. Orn. Biog.
}

Specific Character-Bill strong, rather broad at base; upper mandible black; lower horn-color; wings of moderate length ; second quill longest; third shorter than the first; tail rather long, rounded; upper plumage olive green. Adult with the head, hind part and sides of the neck bluish-gray ; the fore neck and fore part of the breast deep black, with transverse white lines; loral band black; margins of eyelids dusky gray, the lower parts bright yel. low, upper parts olive green. Female with the sides of the neck and a band across the breast ash-gray; throat yellowish-white ; upper and lower parts duller than the male. Young with the entire upper parts plain dull greenish-brown; lower parts lighter brown; abdomen and lower tail coverts dull yellow. Length five inches, wing two and three-eighths.

This species was first described by Wilson, from a male specimen which he shot in the early part of June, on the borders of a marsh, within a few miles of Philadelphia, the only specimen that he ever met with; according to $\mathrm{Mr}$. Audubon, it ranges from Texas northward to Nova Scotia, and throughout the interior to the Columbia River. The specimen in my possession was shot by $\mathbf{S}$. F. Baird, in Cumberland County, $\mathrm{Pa}$. ; and a few years since, a specimen was obtained by $\mathrm{Mr}$. Bell on Long Island, the only one which I have known to have been procured here. 


\title{
GENUS HELINAIA-AUDUBON.
}

\author{
SWAMP WARBLER.
}

[In these birds the bill is nearly as long as the head, compressed toward the end, and tapering to a very acute point; wings rather long; tail of moderate length, nearly even.]

\section{HELINAIA SOLITARIA-WILSON.}

\section{BLUE-WINGED YELLOW SWAMP WARBLER.}

Blue-winged Yellow Warbler, Wils. Amer. Orn.

Sylvia solitaria, Bonap. Syn.

Blue-winged Yellow Warbler, Nutt. Man.

Blue-winged Yellow Warbler, Sylvia solitaria, Aud. Orı. Biog.

Specific Character-Bill straight, tapering to a very acute point -both mandibles black; toward the point, lighter; third quill longest; second longer than the fourth; forehead, crown, and lower parts bright yellow; loral space black; two white bands on the wings. Adult with the forehead and crown rich yellow; upper parts, including the hind neck and occiput, bright green, with a tinge of yellow on the rump; loral space black; wings and tail grayish-blue, the tips of the secondary coverts and those of the first row of small coverts white; a patch of white on the four outer tail feathers, occupying nearly all the inner webs of the first two, confined to about one-third of the inner web of the third, diminishing to a small spot on the inner web of the fourth; lower parts bright yellow; lower tail coverts white, faintly tinged with yellow. Young with the forehead and upper parts yellowish-green; lower parts tinged with green. Length five inches, wing two and a half.

The birds of this class are readily detected by the form of the bill. The Genus consists, as far as described, of ten species, only four of which I have been able to procure on Long Island, although I should not be surprised to hear of others occurring here-as, for instance, a single specimen of the Tennessee Warbler $[H$. peregrina] was shot by Mr. Bell in Rockland County, and it is not 
improbable that other migratory species may extend to Long Island. This class of birds is not altogether confined to damp situations, as their title would seem to imply, although they have a predeliction for low grounds, and usually keep among the bushes. The present species has been shot during summer on the Catskill Mountains, and it is not improbable that it breeds there; it has also been shot in Rockland County, and other parts of the State of New York, but seems to be no where abundant. On Long Island it is quite rare. I have not seen a specimen for the last two years, and the number that I have met with during any season has been very limited.

\section{HELINAIA VERMIVORA-LATHAM.}

\section{WORM-EATING SWAMP WARBLER.}

Worm-eating Warbler, Sylvia vermivora, Wils. Amer. Orn.

Sylvia vermivora, Bonap. Syn.

Worm-eating Warbler, Sylvia vermivora, Aud. Orn. Biog.

Specific Character-Bill nearly as long as the head; horn color, darker above; first and second quills about equal; third scarcely shorter; upper parts of head with three brownish-yellow and four black bands. Adult with the upper part of the head black, with a broad medial band of pale brownish yellow-a similar band over the eye; a line of dusky behind the eye ; cheeks, throat, fore neck, and lower parts pale brownish-yellow; upper parts light olive-green; quills and tail feathers brown, margined with light olive-green sides of the body tinged with the same. Length five inches and a half, wing two and three quarters.

This species exhibits more truly the type of the Genus than the former or either of the following two. It is generally confined to the wet, miry part of the woods, and loves to rustle among the dried leaves of broken branches that are occasionally lodged in the trees; by this manœuvre it is known to be nigh at hand when not seen. Its note is low, and but seldom heard. 


\section{HELINAIA CHRYSOPTERA-LINN.}

\section{GOLDEN-WINGED SWAMP WARBLER.}

Golden-winged Warbler, Sylvia chrysoptera, Wils. Amer. Orn.

Sylvia chrysoptera, Bonap. Syn.

Golden-winged Warbler, Sylvia chrysoptera, Nutt. Man.

Golden-winged Warbler, Sylvia chrysoptera, Aud. Orn. Biog.

Specific Character-Bill shorter than the head; upper mandible black; lower horn color, at base; second and third quills equal; first longer than the fourth; forehead, crown and outer webs of the secondary coverts and the tips of the first row of small coverts yellow. Adult with the upper part of the head rich yellow; outer webs of the secondary coverts and the tips of the first row of small coverts pale yellow; a line from the nostril back to the eye, and a patch behind the eye, the throat, and a broad band on the lower portion of the fore neck black; a band from the base of the lower mandible down the side of the neck, with a line over the eye, white; upper parts light ash-gray; quills and tail feathers brown, the former edged with pale blue-the three outer feathers of the latter with a patch of white on the inner webs; lower parts grayish-white. Female with the throat gray, the black on the fore neck and sides of the head wanting, the yellow markings on the head and wings duller, as is the general plumage. Length five inches, wing two and one quar, ter.

On Long Island this species occurs only in small numbers, and according to my observations is not an annual visitor, though it may visit us more frequently and in greater numbers than I am aware of, but avoid detection from its habit of leeping among the undergrowth and small bushy trees. It is an exceedingly restless bird, flies quickly, and seems to be in continual motion, darting after insects, or hopping about from twig to twig among the bushes. 


\title{
HELINAIA RUBRICAPILLA-WILSON.
}

\author{
NASHVILLE WARBLER.
}

Nashville Warbler, Sylvia rubricapilla, Wils. Amer. Orn.

Sylvia rubricapilla, Bonap. Syn.

Nast,ville Warbler, Sylvia rubricapilla, Nutt. Man.

Nashville Warbler, Sylvia rubricapilla, Aud. Orn. Biog.

Specific Character-Bill shorter than the head; very slender toward the end; lower mandible horn color; darker above; the second and third quills equal; fourth scarcely shorter, longer than the first. Adult with the upper parts of the head and neck light ash, a little inclining to olive; crown spotted with deep chestnut, in small touches; a pale yellowish ring round the eye; whole lower parts bright yellow, except the middle of the abdomen, which is white; back yellowish-olive, slightly skirted with ash; rump and tail coverts brighter; wings darker; outer primaries edged with grayish white; secondaries broadly edged with green; tail slightly forked, lighter than the wings and edged with the color of the back.Female faintly spotted on the crown with dull red, which color is wanting in the young: Length four inches and a half, wing two and three-eighths.

This species was first discovered by Wilson in the State of Tennessee, not far from Nashville. On Long Island it is not very abundant, though by no means rare. It is found in various parts of the Union, and seems to prefer the orchards and low woods. With us, it is a bird of passage, arriving in spring usually about the middle of May-spends a short time among its favorite haunts-and passes on to breed. According to Swainson, some extend their migrations to the fur countries. It is a well marked species, and has a sharp shrill note. 


\section{GENUS MNIOTILTA-VIEILL.}

\section{CREEPING WARBLER.}

[Bill slender, rather long, tip acute, compressed toward the end; head rather small; body slender; wings long; tail of a moderaie length, nearly even ; tarsi shorter than the middle toes; feet and toes slender.]

\section{MNIOTILTA VARIA-LINN.}

Black and white Creener, Certhia varia, Wils. Amer. Orn.

Sylvia varia, Bonap. Syn.

Creeping Warbler, Nutt. Man.

Black and white Creeper, Certhia varia, Aud. Orn. Biog.

Specific Character-Bill rather long and slender; wings long, with the second and third quills longest, and about equal, the first slightly shorter and exceeding the fourth; tail of moderate length, and nearly even.

Adult with plumage very soft, the colors black and white; the middle of the breast, abdomen, a band on the upper part of the head, a broad line over the eyes, a band on the sides of the neck, and a patch on the outer tail feathers, white; two bars on the wings of the same color, formed by the tips of the secondary and first row of small coverts.

Female with the lower parts grayish-white, sides with dusky streaks. Length five inches and a quarter, wing two and five eighths.

This neatly attired bird arrives in the spring in company with our early warblers. It inhabits various situations, but is more generally confined to the woods, and is frequently observed creeping round the trunks of the largest trees, much in the manner of the Nuthatch. It is quite common, and remains during the summer months.

"This Genus connects the Sylvicolinæ with the Certhianæ."Audubon. 


\section{F A M I L Y C E R T H I N E}

\section{CREEPERS}

\section{GENUS CERTHIA-LINN}

\section{TREE CREEPER.}

[Bill about the same length as the head, compressed, asched, acute at tipextremely slender; general form slender; wings of moderate length; tail long of twelve pointed feathers; tarsi compressed, slender, longer than the middle toe; feet and toes slender-hind toe larger.]

\section{CERTHIA FAMILIARIS-LINN.}

\section{BROWN TREE CREEPER.}

Brown Creeper, Certhia familiaris, Wils. Amer. Orn.

Cerıhia familıaris, Bonap. Syu.

Brown Creeper, Nutt. Man.

Brown Creeper, Certhia familiaris, Aud. Orn Biog.

Specific Character-Bill compressed, slender, arched; tail long, graduated; the feathers stiff and pointed. Adult with upper parts reddish-brown; darker on the head; all the feathers with a central dull whitish streak; lower parts silvery white; sides of the body tinged with brown; wings deep brown, the coverts tipped with dull yellow-the secondaries at the base barred with the same; both webs of the quills crossed with a dull yellowish band, excepting the outer three, which are plain brown-the rest with a greenish-yellow patch on their outer web toward the tips, whichare dull white; rump and upper tail coverts rusty-brown; tail feathers very long, of a yellowish-brown color-darker next to the shafts, and tapering to a point ; bill about half an inch long, slender arched, the point acute; cheeks dark brown; a band over the eye silvery white. Length five inches, wing two and five eighths.

With us the Brown Creeper is found at all seasons of the year. It frequents the woods, in pursuit of food; when thus employed it is observed creeping along the trunks of the trees, directing its course upward to the higher branches-sometimes spirally, and often in a direct line. The tallest trees are usually preferred-and having accomplished its journey, it shoots downward, alighting on the body of a neighboring tree, a few feet above the roots, when it 
recommences its occupation, carefully examining every crevice for insects as it ascends.

The Brown Creeper is an exceedingly active, restless bird, moving about with great nimbleness, and seeming to be almost constantly pursuing its favorite fare. When observed, it quickly passes round to the opposite side of the tree, changing its position with the movement of its pursuer-who, if not accustomed to its manners, can seldom prevent its escape.

It often associates with the Downy Woodpecker and White-bellied Nuthatch, and sometimes all three are observed pursuing similar employment on the same tree.

\section{GENUS TROGLODY TES-CUVIER.}

\section{WRENS.}

[Bill about the length of the head, slender, compressed, slightly arched, tip acute; head oblong-wings short, rounded; tail short, rounded, of twelve feathers; tarsi longer than the middle toe; feet rather stout, toes moderateinner free-hind toe larger, with a long claw.]

\section{TROGLODYTES HYEMALIS-VIEILL.}

\section{WINTER WREN.}

Winter Wren, Sylvia Troglodytes, Wils. Amer. Orn.

Troglody'es europœus, Boisap. Syn.

Troglodytes hyemalis, Winter Wren, Sw. \& Rich.

Winter 1 ren, Troglodytes hyemalis, Nutt. Man.

Winter Wren, Troglodytes hyemalis, Aud Amer. Orn.

Specific Character-Bill rather short ; tail short, rounded; wings rather short; fourth quill scarcely longer than the third; second shorter than the fifth. Adult with the upper parts reddish-brown, faintly barred with dusky-rather darker on the head; upper tail coverts lighter-a spot of white on the tips of the secondary and first row of small coverts; wings and tail barred with black; lower tail coverts with a white spot on their tips; lower parts pale reddish brown, barred with black; fore neck and fore part of the breast lighter, and more faintly barred. Length four inches, wing two.

Mr. Audubon found a pair breeding in the Pine Forest, Pennsylvania, and made a similar discovery in the State of New York, in the neighborhood of the Mohawk River. 
The Winter Wren is an active bird and fond of keeping among the low bushes, or running along the stone walls; when surprised, it disappears in the small openings in the same manner as a mouse. It also frequents the borders of creeks, visits the farmer's door-yard, searches the brush-pile, and is sometimes seen in the gardens of the city mounted on a dry stalk, uttering a sprightly and agreeable song.

In the month of October this species arrives among us from the North and remains until early in the spring.

\title{
TROGLODYTES RDON-VIEILL.
}

\section{HOUSE WREN.}

\author{
House Wren, Sylvia domestica, Wils. Amer. Orn. \\ Troglodytes aedon, Bonap. Syn. \\ House Wren, Nutt. Man. \\ Troglodytes aedon, House Wren, Sw. \& Rich. \\ House Wren, Troglodytes aedon, Aud. Orn. Biog.
}

Specific Character-Bill, along the gap, ten-sixteenths of an inch; length of tail one and one quarter. Adult with the upper parts dark reddish-brown, faintly barred with dusky; head dull brown, marked with dusky; upper tail coverts brighter; wings and tail brown, tinged with reddish-brown and distinctly barred with brownish-black; lower tail coverts barred with dusky. Length four inches and a half, wing two.

This well known bird arrives among us about the middle of May, and during its stay throughout the summer months is seen in all our gardens, collecting insects, on which it feeds. The sprightly song of this familiar species is also heard in the pleasure grounds of cities, and to compensate it for the valuable service rendered in removing the insects that infest the blossoms, it is not unusual for the proprietors to provide for it a comfortable dwelling in which to rear its brood. The eggs are from five to seven, of a reddish flesh color, finely dotted with a rather deeper tint. Two broods are raised in a season. In the latter part of September it migrates southward. 


\title{
TROGLODYTES AMERICANUS-AUD.
}

\author{
WOOD WREN.
}

\section{Wood Wren, Troglodytes americana, Aud. Orn. Biog.}

Specific Character-Length of bill eleven-twelths of an inch; of tail, one inch and three quarters; wings short; fourth quill longest; third and fifth equal. It is closely allied to the House Wren, from which it differs in having the bill stronger, the tail feathers longer and in all respects it is a larger species. Adult with the bill nearly straight, of moderate length ; upper parts dark reddish-brown, duller and tinged with gray on the head, indistinctly barred with dusky; lower parts brownish-gray, faintly barred on the fore neck, breast and sides of the abdomen; cheeks light gray, the fearhers tipped with brown; wings short, with the fourth quill longest; tail rather long, much rounded; wings and tail feathers undulatingly barred with blackish brown; lower tail coverts distinctly barred. Length four inches and seven-eighths, wing two and one-eighth.

This species was first discovered by Mr. Audubon, a few miles from Eastport, in the State of Maine, in the summer of 1842. According to Mr. Audubon, it has been obtained in Vermont and South Carolina, and has been observed in Pennsylvania by Mr. Baird. A few have been shot on various parts of Long Island, and I have no doubt that it occurs in all the Middle and Eastern States; but from the strong resemblance it bears to the House Wren, has generally been overlooked by collectors. 


\title{
TROGLODYTES LUDOVICIANUS-BONAP.
}

\author{
GREAT CAROLINA WREN.
}

Great Carolina Wren, Certhia Caroliniana, Wils. Amr. Orn. Troglodytes ludovicianus, Bonap. Syn.

Great Carolina Mocking Wren, Nutt. Man.

Great Carolina Wren, Troglodytes ludovicianus, Aud. Orn. Biog.

Specific Character-Bill strong; a yellowish white band over the eye; its superiority in point of size over all the other species is at all times a specific distinction. Adult male with the upper parts brownish-red; a broad streak of yellowish-white commencing at the nostril and passing over the eye along the side of the head; a band of reddish behind the eye-under the eye, a spot of dusky gray; throat dull white; lower parts and sides of the neck pale reddish buff; wings and tail barred with blackish-brown, the outer webs of the lateral tail feathers more distinctly barred; secondary and first row of small coverts tipped with dull white; lower tail coverts of the same color, barred with black. Female without the white markings on the wing coverts-lighter above, and tinged with gray below. Length five inclies and one quarter, wing two and one quarter.

Although chiefly confined to the Southern States, occasionally during the summer months, this large and musical Wren is seen on Long Island, as well as in other parts of the State of New York. It frequents the borders of streams, swamps, and decayed logs, collecting insects, on which it feeds. At times it becomes quite familiar, visits the brush-pile near the cottage door, and executes its varied notes in a spirited and happy manner. 


\title{
TROGLODYTES PALUSTRIS-WILSON.
}

\section{MARSH WREN.}

\author{
Marsh Wren, Trcglodytes palustris, Wils. Amer. Orn. \\ Troglodvtes palustris, Bonap. Syr. \\ Marsh Wren Troglodytes palustris, Nutt. Man. \\ Troglodytes palustris, Marsh Wren Sw. \& Rich. \\ Marsh Wren, Troglodytes palustris, Aud. Orn. Biog.
}

Specific Character-Bill slender rather long; upper part of the head and fore part of the back brownish-black, streaked with white. Adult with the upper parts dark-brown; the upper part of the head and fore part of the back brownish-black; a band of dull white from the nostril over the eye along the side of the head; hind neck and fore part of the back marked with longish spots of the same color; quills dark brown, their outer webs margined with lighter brown; tail barred with blackish-brown, the larger portion of the inner webs of some of the feathers being of that color, the middle pair of feathers lighter and more faintly barred ; sides of the neck light brown, intermixed with gray; lower parts grayish-white; lower tail coverts with a dark-brown spot near their tips. Length five inches, wing two.

On Long Island, during the summer months, this species is quite plentiful. It inhabits the swampy borders of streams, and subsists on small aquatic insects-is an active, restless bird, and continues its harsh notes long after nightfall.

There is another species, (the Short-billed Marsh Wren, T. brevirostris) which $\mathrm{I}$ have no doubt is entitled to a place in this volumebut from having no knowledge of it being met with on the Island, I do not feel at liberty to do other than give it this passing notice. It has been found in Rockland county in this State, and has been observed as far eastward as Massachusetts, and I have not the least doubt that it will yet be found on the fresh water marshes of Long Island. It can be readily distinguished by its short bill, which is much less than that of any other species of the Genus 'Troglodytes. 


\section{F A M I L Y P A R I N Æ.}

\section{TITS.}

\section{GENUS PARUS-LINN.}

[Bill short, straight, strong, rather broad at the base, narrowing towards the end ; nostrils concealed with recumbent frontlet feathers; bristles at the base ; head rounding above, rather large ; neck short; body rather short; wings of moderate length; tail rather long, graduated, of twelve feathers.]

\section{PARUS ATRICAPILLUS-LINN.}

\section{BLACK-CAPT TITMOUSE.}

Black-capt Titmouse, Parus atricapillus, Wils. Amer. Orn.

Parus atricapillus, Bonap. Syn.

Black-capt Titmouse, Nuit. Man.

Black-capt Titmouse, Parus atricapillus, Aud. Orn. Biog.

Specific Character-Upper part of the head, hind neck, throat, and fore neck black; cheeks and sides of the neck white; upper and lower parts yellowish-gray, lighter beneath; wings and tail brown, the feathers edged with bluish-white. Length five inches and a quarter, wing two and five-eighths.

The Black-capped Titmouse, or "Chicadee," is with us a constant resident, and is said to be quite common throughout the year as far north as Hudson's Bay. During the spring and summer months it usually frequents the woods; in autumn it resorts to the cultivated grounds, and at that period feeds on various kinds of seed. In winter, when the ground is covered with snow, it becomes quite familiar, approaches the farmer's door, and during the time of killing the hogs, draws near to the scene of operation, and feeds on portions of fat, \&c. from the offal. It associates in small parties, and is seen climbing round the limbs of trees, frequently hanging by its feet, and pecking at the bark in search of insects and their larvæ. The nest is usually placed in the cavity of a tree. The eggs are six in number, of a white color, minutely speckled with red. I have not known $P$. carolinensis to appear on Long Island. In point of plumage it differs but little or nothing from the present, 
from which it can at all times be distinguished by its smaller size. Some years since, a specimen was shot at Hoboken, which is the only instance which I have known of its having been found in the vicinity of New York, it being chiefly confined to the Southern States.

\section{PARUS BICOLOR-LINN.}

\section{CRESTED TITMOUSE.}

Crested Titmouse, Parus bicolor, Wils. Amer. Orn.

Parus bicolor, Bonap. Syn.

Tufted Titmouse, Parus bicolor, Nutt. Man

Crested Titmouse, Parlis bicolor, Aud. Orn. Biog.

Specific Character-Bill much stronger than the preceaing; head crested. Adult with the bill black, short, and very stout ; forehead black; upper parts, including the crest, lead color; lower parts grayish-white; sides of the body light red ; tail feathers long, of a rather deeper tint than the back; inner webs of the wing quills dusky. Length six inches and a quarter, wing three inches.

On Long Island this species is not so abundant as the former, with which it sometimes associates. Its manner is not so active as the preceding, but it possesses a stronger voice, and delivers a greater variety of notes. It is found in most parts of the United States, and resides with us throughout the year, seeking retirement in the lonely part of the woods among the heavy timber. It is a hardy bird, and braves the severest winters of our climate. It is said to be common to both continents; "in America extends to Hudson's Bay, and in Europe is found in Normandy, and in many parts between that and Sweden." In the spring it feeds chiefly on insects; in winter it subsists on acorns, and other soft shell nuts, and seeds of various plants. The nest is built in the hollow of a tree ; the eggs, six in number, are white, marked near the great end with minute spots of red. 


\section{F A M I L Y S Y L V I A N Æ. \\ WARBLERS.}

\section{GENUS REGULUS-CUVIER.}

KINGLET.

[Bill short, slender, broader than high at base, compressed toward the end-upper mandible slightly notched; head ovate; wings and tail of moderate length, the latter emarginate ; tarsi slender, compressed; claws arched, acutetoes slender, hind toe strongest.]

\section{REGULUS CALENDULA-LINN.}

\section{RUBY-CROWNED KINGLET.}

Ruby-crowned Wren, Wils. Amer. Orn.

Regulus calendula, Bonap. Syn.

Ruby-crowned Wren, Sylvia calendula, Nutt. Man.

Ruby-crowned Regulus, Regulus calendula, Aud. Orn. Bing.

Specific Character-A patch of bright vermilion on the crown; upper parts greenish-olive; lower parts white, tinged with green; young with the vermilion patch on the crown wanting. Adult male with the upper parts greenish-olive; head and sides of the neck tinged with gray; a patch of bright vermilion on the crown; quills and tail dusky, margined with greenish-yellow; a tinge of the same color on the rump; secondary coverts and first row of small coverts tipped with white; eye encircled with dull white; lower parts greenish-white. Female with the tints duller. Length four inches and a quarter, wing two and a quarter.

About the middle of April the Ruby-crowned $W$ ren arrives from the South, and frequents the orchards, procuring its food among the blossoms. It remains with us but a short time. In its migratory course it visits the Fur countries, where it breeds. When in full song, according to $\mathrm{Mr}$ Audubon, (who met with it at Labrador,) its notes excel those of a fine-toned Canary. On its way back to winter quarters, in the latter part of September, it returns to us with its young. At this period it lives chiefly on small winged insects, which it pursues among the tops of the tallest trees, as well as in the orchards. So intent it becomes on securing its prey, that it heeds not the approach of man, nor is it scarcely disturbed hy the renoit of a ginn. 
When searching for food, it is frequently observed hoveringmuch in the manner of the Humming Bird-about the limbs of trees, carefully examining the crevices for lurking insects. A few sometimes remain with us until the middle of October, though generally all move off to the South at an earlier period.

\section{REGULUS SATRAPA-LICHENSTEIN.}

\section{AMERICAN GOLDEN-CRESTED KINGLET.}

Golden-crested Wren, Sylvia regulus, Wils. Amer. Orn.

Regulus cristatus, Bonap. Syn.

American Fiery-crowned Wren, Regulus tricolor, Nutt. Man.

American Golden-crested Wren, Regulus tricolor, Aud. Orn. Biog.

Specific Character-Bill more slender and shorter than that of the preceding ; forehead grayish-white, bordered above with a black band - as are the sides of the head; crown bright orange. Female with the crown pale yellow. Adult male with a band of grayish-white on the forehead, a similar band over the eye, and a fainter band below it; upper part of the head bordered with a black band, the inner margin of which is yellow ; crown bright orange ; sides of the neck ash-gray; upper parts yellowish-gray; a line of dusky from the base of the bill continuing on the sides of the throat, which, with the lower parts, are grayish-white; primaries and their coverts dusky, the former edged with greenish-yellow; secondary coverts and first row of small coverts broadly tipped with yellowish-white; tail dark brown, the feathers edged with the same color as the primaries. Length four inches, wing two and one-eighth.

This beautiful little Wren visits us from the South about the middle of April. In the latter part of May it retires northward, where it breeds. It returns to us in September, and continues with us until quite late in autumn; a few have been seen in the vicinity of New York as late as December. Among us it is more abundant than the preceding species, with which it associates, and resembles it in its general habits. 


\section{GENUS SIALIA-SWAINSON.}

BLUE BIRD.

[Bill rather short, broader than high at the base, compressed toward the ond -upper mandible declinate at tip, notched; head rather large-neck shortbody full--wings long; tail rather long, broad, slightly emarginate; of twelve feathers; tarsi rather short; feet rather stout-toes of moderate length, outer toe united at the base, inner free-hind toe strongest.]

\section{SIALIA WILSONII-SWAINSON.}

\section{COMMON BLUE BIRD.}

Blue Bird, Sylvia Sialis, Wils. Amer. Orn.

Saxicola Sialis, Bonap. Syn,

Erythaca (Sialia) Wilsonii, Sw. \& Rich.

Blue Bird, Ampelie Sialis, Nutt. Man.

Blue Bird, Sylvia Sialis, Aud. Orn. Biog.

Specific Character-Upper parts ultramarine blue; fore neck, breast, and sides of the body light chestnut red; abdomen and lower tail coverts white. Female with the general plumage duller, and about half an inch less. Length seven inches, wing three and three quarters.

This well known bird arrives among us in the early part of March, and remains until the approach of winter. During spring and summer it subsists chiefly on insects, and utters an agreeable and somewhat musical note. It frequents the orchards, gardens, open grounds, and woods. The eggs, which are from five to six in number, are of a pale blue color. It rears two broods in a season, and remains quite late in the autumn, at which period its food consists chiefly of berries, and its song is reduced to a single and rather plaintive note. 


\section{F A M I L Y T T R D I N}

\section{THRUSHES.}

\section{GENUS ORPHEUS-SW AINSON.}

\section{MOCKING BIRD.}

[Bill of moderate length, upper mandible curved, declinate at tip, notchedbody slender-wings rounded-tail very long, much rounded.]

\section{ORPHEUS POLYGLOTTUS-LINN.}

\section{GRAY MOCKING BIRD.}

Mocking Bird, Turdus polyglottus, Wils. Amer. Orn. Turdus polyglottus, Bonap. Syn.

Mocking Bird, Turdus polyglottus, Nutt. Man.

Mocking Bird, Turdus polyglottus, Aud. Orn. Biug.

Specific Character-Tips of wing coverts, basal parts of primaries, outer tail feathers, larger portion of the next and a patch on the inner web of the third, white. Adult male with the upper parts light gray, tinged with yellowish-brown; lower parts grayish-white, the breast darker; wings and tail brownish-black; primary coverts white, as are the primary quills toward their bases; first and second row of wing coverts tipped with the same; tail long, rounded, the outer feather pure white; the larger portion of the next, and a patch on the inner web of the third, and the tips of all excepting the middle pair, white. Female with the plumage duller, the white markings on the wings less extensive. Length of male nine inches and half, wing four and three-eighths.

Although a constant resident in the Southern States, this unrivalled songster occasionally passes the season of re-production on Long Island. The nest is placed among the briars-and, when 
opportunity offers, a hedge fence is selected; the eggs, from four to six in number, are light green, spotted with brown. The food of the Mocking Bird consists chiefly of berries and insects. It is usually observed in the orchards, or about the highly cultivated farms, though at times it frequents the dry sandy beaches in the immediate vicinity of the sea. At Egg Harbor I have been informed that a few years since a bird of this species passed the summer on the beach. It became the pet of the residents, to whom it also seemed much attached-and, as if in return for the attention they paid to its wants, it poured forth its charming melody, which, on calm, bright nights, blending with the subdued voice of the ocean, rendered the scene enchanting beyond the powers of description. Its fame as a vocalist is so well known, that but little can be added to its justly established reputation. It is the Nightingale of America, and according to those who have heard the native notes of both, its voice, both in variety and fullness, is superior to that of Europe's sweetest songster. Its power of imitation is so great, that this highly gifted bird runs over the varied notes of all our songsters, and exeecutes with so much skill, that it would seem as if Nature had so attuned its voice that it might exceed all of the feathered choir. 


\title{
ORPHEUS CAROLINENSIS-LINN.
}

\author{
BLACK-CAPPED THRUSH.
}

Cat Bird, Turdus lividus, Wils. Amer. Orn.

Turdus felivox Bonap. Syn.

Orpheus felivox, Cat Bird, Sw. \& Rich.

Cat Bird, Turdus felivox, Nutt. Man.

Cat Bird, Turdus felivox, Aud. Orn. Biog.

Specific Character-Upper part of the head and the tail black; lower tail coverts dark red; general plumage dark slate color; paler beneath. Length eight inches and three quarters, wing three and five-eighths.

This well known species usually arrives on Long Island in the latter part of April. With us it is very common, and is abundant in all the cultivated districts throughout the Union. It is familiarly known by the name of Cat Bird, from the occasional resemblance of its notes to the voice of a young kitten. Its favorite resort is among the briars and brambles, and it is met with in almost every thicket during spring and summer. The Cat Bird is remarkable for its singular and varied notes, which commence at early dawn and continue until late twilight, excepting during the heat of the day, when it retires to the shady part of the thicket, and passes the time in silence. Although not ranking with our first songsters, at times its voice is clear and melodious-and on certain occasions I have heard it perform in a manner that would not be discreditable to more celebrated songsters.

Early in May this familiar species builds its nest, which is usually placed in a thicket of briars, a few feet from the ground; the materials consist of dry leaves, twigs, and dry grass, lined with fibrous roots. The eggs, from four to five, are plain greenish-blue. 


\title{
ORPHEUS RUFUS-LINN.
}

\author{
FERRUGINOUS THRUSH.
}

\begin{abstract}
Ferruginous Thrush, Turdus rufus, Wils. Amer. Orn. Turdus rufus, Bonap. Syn.

Orpheus rufus, Fox-colored Mocking-Bird, Sw. \& Rich.

Ferruginous Thrush or Thrasher, Turdus rufus, Nutt. Man.

Ferruginous Thrush, Turdus rufus, Aud. Orn. Biog.
\end{abstract}

Specific Character-Adult with the upper parts and tail light brownish-red; two white bands on the wings, formed by the tips of the secondary coverts and first row of small coverts; lower parts yellowish-white, with dark brown markings on the breast and sides of the body; bill long and stout; tail very long and rounded. Length of male eleven inches and a half, wing three and seveneigliths.

This large and musical Thrush is more familiarly known by the name of Brown Thrasher. It arrives among us in the latter part of April or early in the month of May, and is generally distributed throughout the Union. In the blooming month of May, when Nature, true to her charge, perfumes the air with the aromatic blossoms that meet you at every turn, and the gray covering of hill and dale, as if by magic, has changed to a rich and grassy carpet, then you hear the loud and clear notes of the Ferruginous Thrush, mingling with the sweet and varied notes of our native sonsters, as if pouring forth his morning lay, in praise to the Creator of all.

The nest is constructed near the ground--frequently on itamong the briars; the eggs, five in number, are pale dull white, freckled with reddish-brown. In the early part of the season they subsist chiefly on worms; when berries and cherries ripen they prefer this wholesome fare. 


\title{
GENUS TURDUS-LINN.
}

\author{
THRUSH.
}

[Bill of moderate length, rather stout, straight, from the nostrils compressed -upper mandible slightly curved, declinate at tip, notched, bristles at base ; head of moderate size; neck rather short; body full; wings moderate; tail rather long, nearly even; tarsi longer than the middle toes; feet robust; toes rather long-lateral toes almost equal-hind toe strong; claws arched, compressed, acute, that of the hind toe rather large.]

\section{TURDUS MIGRATORIUS--LINN.}

\section{RED-BREASTED OR MIGRATORY THRUSH.}

Robin, Turdus migratorius, Wils. Amer. Orn.

Turdus migratorius, Bonap. Syn.

Merula migratoria. Reb-breasted Thrush, Sw. \& Rich.

American Robin, or Migratory Thrush, Turdus migratorius, Nutt. Man.

American Robin, or Migratory Thrush, Turdus migratorius, Aud. Orn. Biog.

Specific Character-Lower parts red orange, except the abdomen, which is white. Adult male with the upper parts dark gray, tinged with olive; wings blackish-brown, margined with dull white -tail feathers darker than the wings, the outer two tipped with white; throat white, streaked with black; in some specimens the throat is pure white; lower part of the fore neck, breast, and sides of the body, reddish-orange; abdomen white; lower tail coverts dusky, tipped with white. Female with the colors duller. Length of male ten inches, wing five and a half. Female about one inch less.

In the history of the North American feathered tribe there is no species more universally known than the American Robin. It is found in all parts of the United States; and in its northern migrations proceeds to the Fur countries. It is also said to visit the western side of the continent, and has been observed during winter in South America, in the vicinity of Para, by Mr. W. E. Moore. 
With us it is a very common species; here, as in many other por. tions of the middle districts, it may be said to be a constant resident, though far more numerous in the early part of spring and autumn than in the colder and summer months. Early in April it begins to pair, and at that period the loud notes of the male are heard all over the Island.

The nest of the Robin is found in the woods, but more frequently in the orchard, on the bough of an apple tree; it is formed of hay and straw, cemented with mud, the interior lined with fine dry grass. The eggs, usually four in number, are plain bluish-green. The young are frequently taken at a very early age, and reared in cages. It endures confinement well, and even in this situation sings with a great deal of spirit, and is capable of being taught to whistle simple tunes. In the spring it subsists chiefly on worms and various insects; as the season advances, it acquires a fondness for the early fruits; at the approach of winter it feeds on the frost grapes, "pokeberries," (Phytolacca decandra,) cedar berries, and the fruit of the Viburnum prunifolium, a black berry which grows in clusters on bushy tiees from ten to fifteen feet high, situated on the sides of hills, swamps, and along the fences. In the depth of winter its chief resort is the cedars, changing its location as the berries are consumed. During the coldest weather it for a short time disappears, especially in the absence of its favorite fare.

Like the rest of this Family, as is also the case with most of our Sparrows, the Robin never advances with a regular succession of steps, its progression on the ground being performed in a hopping or jumping manner. With most persons it is a great favorite, and is suffered to build its nest and rear its brood without molestation. In autumn this species assembles in large flocks, and is shot without mercy by gunners from the neighboring towns and villages, as a matter of amusement. Such amusement, however, is only be. coming to juvenile sportsmen. 


\title{
TURDUS MUSTELINUS-GMEL.
}

\author{
WOOD THRUSH.
}

Wood Thrush, Turdus melodus, Wils. Amer. Orn.

Turdus mustelinus, Bonap. Syn.

Wood Thrush, Turdus mustelinus, Nutt. Man.

Wood Thrush, Turdus mustelinus, Aud. Orn. Biog.

Specific Character-Upper part of the head and hind neck brownish red, fore part of the back paler, inclining to olive on the rump and tail ; lower parts white, marked all over excepting on the ab. domen and lower tail coverts with blackish-brown spots. Adult with the upper part of the head and hind neck brownish-red; fore part of the back tinged with yellow ; hind part of the back, rump, upper tail coverts, and tail, tinged with olive; lower parts white, distinctly marked with roundish spots of blackish-brown, which run in chains on the fore neck, breast and sides of the body; throat white, with a line of dusky on either side. Length eight inches, wing four and a quarter.

The Wood Thrush or Ground Robin arrives on Long Island in the latter part of April, or early in May, according to the progress of vegetation. Although rather solitary in its habits, it is lively and cheerful, and like many of mortal kind, whiles away its solitude with a pleasing song, which commences at morning's dawn, and continues until after sunset, excepting at noon-day, when it retires to the thick woods, where, like the most of our songsters, it passes the hottest part of the day in silence. To those who are fond of rambling through the woodlands, the clear tones of the Wood Thrush must be well known.

It is found in all parts of the Union, choosing its residence in the shady and tangled parts of woods-usually in the neighborhood of some woodland brook. Its food consists of various kinds of insects and berries. The nest is generally placed in low situations; the eggs are light blue, and from four to five in number. 


\title{
TURDUS WILSONII-BONAP
}

\author{
WILSON'S THRUSH.
}

Tawny Thrush, Turdus mustelinus, Wils. Amer. Orn.

Turdus Wilsonii, Bonap. Syn.

Merula minor, (Swainsou) Little Tawny Thrush, Sw. \& Rich.

Wilson's Thrush, or Veery, Turdus Wilsonii, Nutt. Man.

Tawny Thrush, Turdus Wilsonii, Aud. Orn. Biog.

Specific Character-Adult with the entire upper parts including the tail feathers uniform tawny brown; fore neck and a small portion of the breast, pale yellowish-brown, marked with spots of darker brown; sides of the body ash; rest of the lower parts grayishwhite. Length seven inches, wing four.

This species was first described by Wilson. He states that it makes its appearance in Pennsylvania from the South about the beginning of May, stays a week or two, and passes on to the aorthern and high mountainous districts to breed. It visits us in the spring; and continues with us during the summer. Although not possessing the solitary habits of the former, it is by no means sociable, being rather shy and timid. It resorts to the shady woods, where it passes the most of its time on the ground; searching for insects, which form the chief part of its food. Its note is a sharp chirrup, occasionally in a strain approaching a song. 


\title{
TURDUS MINOR-GMEL
}

\section{HERMIT THRUSH.}

\begin{abstract}
Hermit Thrush, Turdus solitarius, Wils. Amer. Orn. Hermit Thrush. Turdus minor, Aud. Orn. Biog. Turdus minor, Bonap. Syn. Litile or Hermit Thrush, Turdus minor, Nutt. Man. Merula solitaria, Hermit Thrush, Sw. \& Rich.
\end{abstract}

Specific Character-Adult with the upper parts deep olive brown; rump, upper tail coverts and tail brownish-red; throat, fore neck and fore part of the breast approaching to cream color, and marked with brownish-black spots, which become more faint on the lower part of the breast, which, with the abdomen is white; lower tail coverts and sides of the rump pale buff; the sides of the body tinged with olive. Length seven inches, wing three and three quarters.

In the Southern States the Hermit Thrush is a constant resident. A bout the middle of May it arrives on Long Island, and takes up its abode during the summer in the deep and shady parts of the woods. It is generally seen alone, hopping about on the ground, or among the low bushes, in search of berries, on which it feeds, or perched on a low bough uttering its plaintive note. By a casual observer this species might be mistaken for the Wood Thrush, which it somewhat resembles in plumage. It can, however, be readily distinguished by its smaller size. The plumage is duller, and it differs in its manners. At times the Hermit Thrush is heard chanting a low and musical song, but it is destitute of those sweet, clear and rich tones which characterise the song of the Wood Thrush. Its nest is usually placed on low branches, and is formed of grass and weeds of different kinds, with great attention to the neatness of the interior. The eggs, from four to five and sometimes six in number, are pale greenish blue, spotted with olive. 


\section{TURDUS OLIVACEUS.}

\section{OLIVE-BACKED THRUSH.}

Specific Character-Upper parts uniform dark brownish-olive.Adult with the second primary longest, first and third equal; a line from the bill to the eye, circle round the eye, and sides of the neck rufous; throat cream color, inclining to rufous; fore part of breast and the throat marked with saggitate spots, smaller and more decided than those of T. minor; sides light grayish-brown; under tail coverts pure white; abdomen white, spotted with light grayish brown; tarsi one inch long, [tarsi of T. minor one and a quarter ;] bill short, stout, dark brown, approaching to black ; form comparatively slender; upper parts uniform dark brownish-olive; outer webs of the primaries rather brighter; tail feathers duller. Length seven inches, wing four.

On referring to the Minutes of the Lyceum of Natural History, New York, we find in the month of December, 1839, a communication made by the late H. C. De Rham, in reference to a confusion existing among the North American Family Turdinæ [Thrushes.] Mr. De Rham in his communication stated that he had detected a confusion in the arrangement of this branch of our Ornithology, but not having had an opportunity fully to investigate the subject, he was not at that moment prepared to unravel it, but he hoped to be able to do so at a future period. Shortly after this statement, and while practically in pursuit of this department of Natural History, [Ornithology,] he fell a victim to disease. By that sad event, the Society was deprived of a highly valuable member, and the science of Ornithology of one of its most zealous and liberal supporters.

In pursuing the same subject, we find the confusion relative to the synonyms applied to the Thrushes by various authors, still exists. After a careful investigation, made by comparisons with speci- 
mens in my possession, as well as those in the extensive collections of Messrs. Lawrence and Bell, it is found that the above Thrush was first described in the Fauna Boreali, or Northern Zoology, by Swainson and Richardson, under the name of Merula Wilsoniimistaking it, as we suppose, for the T. Wilsonii of Bonaparte, and describing the true $\mathrm{T}$. Wilsonii undrr the name of $\mathbf{M}$. minor, which applies to the Hermit Thrush, T. minor, of Gmelin. As the matter now stands, we feel at liberty to separate it from other species, by applying the name of [T. olivaceus,] Olive-backed Thrush.

The Olive-backed Thrush is quite common with us during spring and autumn; from never having been able to procure a specimen during summer, we suppose that it goes farther north to breed. It inhabits similar situations with T. Wilsonii, with which it is often associated.

\section{F A M I L Y M O T A C I L L I N}

\section{WAGTAILS.}

\section{GENUS SEIURUS-SWAINSON.}

\section{WOOD WAGTAILS.}

[In these birds the bill is of moderate length, straight, slender, compressed toward the end, broader than high at base; bristles slight; wings and tail of moderate length, the latter even; tarsi, leet and twes slender, as is the general form.]

\section{SEIURUS AUROCAPILLUS-LATHM. GOLDEN-CROWNED WOOD WAGTAIL.}

Golden-crowned Thrush, Turdus aurocapillus, Wils. Amer. Orn. Sylvia aurocapilla, Bonap. Syu.

Seiurus aurocapillus, (iolders-crowned accentor, Sw. \& Rich.

Golden-crowned Thrush or Oven-Bırd,Turdus aurucapillus. Nutt. Man.

Golden-crowned Thrush, Turdus aurocapillus, Aud. Orn. Biog.

Specific Character-First quill scarcely longer than the second, which is about equal to the third. Adult male with the crown brownish-orange, bordered on either side with black; upper parts olive; lower parts white, with dusky markings on the breast and 
sides of the body; a dusky line on the sides of the throat, which is pure white. Female, with the crown paler. The conspicuous marling on the crown of the adult wanting in the young. Length six inches, wing three.

During the summer months, this species is quite cormmon on Long Island. In its habits it is rather retiring, preferring the woodlands. It builds its nest, which is formed of dry leaves and grass, on the ground; the eggs, which are from four to six, are white, spotted with reddish-brown. Its song consists of two shrill notes, repeated in a hurried manner; in autumn it migrates southward.

\section{SEIURUS NOV EBORACENSIS-GMEL.}

\section{AQUATIC WOOD WAGTAIL.}

Water Thrush, Turdus aquaticus, Wils. Amer. Orn.

Sylvia novahoracensis, Bonap. Syn.

Selurus aquaticus, Aquaticus accentor, Sw. \& Rich.

New York or Aquatic Thiusb, Turdus novaboracensis. Nutt Man.

Lcuisiana Water Thrush. Turdus ludovicianus, Aud. Orn. Biog.

Common Water Thrush, Turdus aquaticus, Auũ. Orn. Biog.

Specific Character--Second and third quills about equal, scarcely longer than the first; tail emarginate. Adult with the upper parts dull brown, tinged with green; wings and ta:l feathers rather darker; a line of yellowish-white before and behind the eye, below which there is a line of dusky; lower parts dull white tinged with yellow, deeper on the abdomen; throat and fore neck spotted with dusky; breast and sides of the body marked with long spots of Blackish-brown; legs flesh-colored. Length of male six inches, wing two and seven-eighths. Female rather smaller.

With us, the Water Thrush arrives in the latter part of April, remains but a short time, and retires inland to breed. Dr. Richardson mentions that this bird was seen at Carlton House, where it frequented the moist and thickly wooded points of the river. It arrived in May, and disappeared after a few days, probably going farther north to breed.-Fauna Boreali Americana.

It returns to us in the latter part of August, frequents the brooks 
and wades into the shallow streams in quest of aquatic insects. It sings with a great deal of spirit, possessing a loud, sweet and clear voice. The difference in size, as well as in shades of plumage, and color of the legs, (those parts in some being bright yellow) has induced sorne persons to suppose that they were two species confounded into one. Mr. Audubon considers them varieties.

\section{GENUS ANTHUS-BECHST.}

\section{PIPIT.}

[Bill of moderate length, slender, as broad as high at the base, straight, compressed toward the end, slightly notched at tip : head rather small, neck short; body rather slender; wings long; tail rather long, emarginate; tarsi much compressed, slender ; toes slender ; claws arched, that of the hind toe long.]

\section{ANTHUS LUDOVICIANUS-LICHENSTEIN.}

\section{AMERICAN PIPIT,}

Brown Lark, Alateda rufa, Wils. Amer. Orn.

Anthus spinoletta, Bonap. Syn.

Brown Titlark, Aud. Orn. B:og.

Specific Character-Bill slender; tail black, larger portion of the outer feather, and a spot toward the end of the next, white. Adult with the upper parts brownish-olive, touched with dusky; a whitish spot over the eye; secondary and smaller coverts tipped with dull white, the next with a white spot on the inner web toward the end next to the shaft; throat white; sides of the neck, the breast, and sides of the body, marked with dusky spots, which are more numerous on the fore part of the breast, and more rounded; those on the sides of the body are longer, and confined to the central parts of the feathers; rest of the lower parts brownish-white. Length six inches, wing three and a half. 
During autumn this species is found in small flocks in the ploughed fields and open plains; on the ground it has a rapid movement; when alarmed, it takes wing, mounts high in the air, whirls around, and descends with considerable velocity. On the approach of spring it retires to the Fur countries, where it is said to breed.

\section{F A M I L Y A L A U D I N Æ.}

\section{LARKS.}

\section{GENUS ALAUDA-LINN.}

\section{LARK.}

[Bill rather short, robust, straigh:, conic, acute-the upper mandible projecting beyond the lower; head rather large, neck short, body full; wings of moderate length; tail generally emarginate, of twelve feathers ; tarsi compressedlonger than the middle toes; feet and toes rather stont; hind toe furnished with a long claw, which is nearly straight, tapering, and acute.]

\section{ALAUDA ALPESTRIS-LINN.}

\section{SHORE LARK.}

Shore Lark, Alauda cornuta, Wils. Amer. Orn.

Alauda alpestris, Bonap. Syn.

Horned or Shore Lark, Alauda cornuta, Sw. \& Rich.

Shore Lark, Nutt. Mau.

Shore Lark, Alauda alpestris, Aud. Orn. Biog.

Specific Character-Head slightly crested; hind claw half an inch long, nearly straight; outer webs of the outer feathers, and their tips white; the rest more slightly tipped with duller white. Adult male with a band on the forehead, continuing behind the eye, which, with the throat and sides of the neck, are pale yellow; a broad black patch on the lower neck; a black band from the base 
of the upper mandible, extending back to the eye, and curving downwards about half the length of the neck; upper parts blackish brown, the feathers margined with pale brown; upper tail coverts reddish-brown; tail black, the outer two feathers margined externally with white, the middle pair broadly margined with brown, and slightly tinged with reddish toward the base; lesser wing cov. erts dull red, and tipped with white, as are the secondaries and their coverts ; lower parts dull white, with dusky brown markings on the breast and sides of the body ; the feathers over the eyes are long, which it has the power of erecting. Female with the plumage not so bright, and the black bands on the head and neck wanting. Length seven inches, wing three and seven-eighths.

The Shore Lark arrives on Long Island in the latter part of October, and remains, according to the mildness of the season, until the early or latter part of March, when it takes its departure northward, and it is said extends to the shores of the Arctic seas.

It lives in society, and dwells almost exclusively on the ground -is usually observed on the dry, sandy fields and plains, but during deep snows, is seen searching for foor along the sea shore. It feeds on the seeds of various wild plants, and when opportunity offers, regales itself on the produce of the cultivated crops, such as wheat, oats, and buckwheat, to obtain the scattered seeds of which it sometimes frequents the "stubble" field. It also swallows large quantities of sand, which, with particles of shells, and bits of seaweed, I have found in its stomach. During its stay with us it gets very fat, and is shot to supply the demand in our market. Like the Brown Lark, with which it is at times associated, it is capable of rapid gait; and when surprised, mounts in the air, performs a few evolutions, and usually descends near the spot from whence it had been put to flight. Mr. Audubon, who found it breeding at Labrador, informs us that at that interesting period the male sings sweetly. With us, its song is reduced to a single chirp, and that is not often heard except when it is moving about on the wing. 


\title{
F A M I L Y F R I N G I L L I N \&
}

\section{FINCHES.}

\section{GENUS PLECTROPHA NES-M Y R}

\author{
LARK BUNTING.
}

[Bill very short, robust, tapering, somewhat compressed-upper mandible considerably narrower than the lower; head of moderate size, ovate; neck short ; body compact; tarsi shorter than the middle toe and ciaw ; claws longthat of the hind toe, froduced; wings long, pointed; tail rather long, emarginate.]

\section{PLECTROPHANES NIVALIS-LINN.}

\section{SNOW LARK BUNTING.}

Snow Bunting, Emberiza nivalis, Wils. Amer. Orn.

Emberiza nivalis, Bonap. Syn.

Emberiza (Plectrophanes) wivalis, Snow Bunting, Sw. \& Rich

Snow Bunting, Emberiza uivalis, Nutt. Man.

Snow Bunting, Emberiza nivalıs, Aud. Orn. Biog.

Specific Character-Bill brownish-yellow, the point dusky; hind claw three-eighths of an inch long; arched; tail emarginate, larger portion of outer three feathers white. Adult with the upper parts grayish-brown, streaked on the fore part of the back with black, with a reddish tinge on the wing coverts and rump; a spot of dark brown on the upper part of the head, and a similar spot on the sides of the breast; the inner secondaries are white, as are the outer two tail feathers, excepting a small spot on the ends; the third feather has a patch of white occupying the larger part of the inner web; the rest of the tail feathers and their primaries are brown; lower parts are dull white, with a reddish tinge on the sides of the body. The specimen now before me was shot in the winter. In summer the back scapulars, inner secondaries, terminal portion of the pri- 
maries, and four middle tail feathers black. Female with those parts tinged with brown. Length seven inches, wing three and three eighths.

The Snow Bunting inhabits during summer the northern reigons of both continents, migrating at the approach of winter to warmer parts. According to Montagu, "these birds appear in the north of Scotland in large flocks during winter, and some few are said to breed upon the highest mountains with the Ptarmigans; but in the south of England it is rarely seen."

On Long Island, as in other parts of the middle districts of the United States, it arrives in the early part of December. It is extremely hardy, and prefers the colder climates of both hemispheres, its migrations depending entirely on the supply of food, which to obtain it has sometimes proceeded in the U. States as far south as Maryland. On its first arrival it is very lean, but soon becomes fat from feeding on the seeds of dried rank weeds and withered grasses. When in good condition its flesh is much esteemed; it graces the table of the epicure, and by some of its admirers it is termed Ortolan, but it is more generally known by the name of "White Sñow Bird." The Snow Bunting inhabits situations similar to the Lark, like which it displays much activity when collecting its food, and is often seen running with great nimbleness. It alights on fence-rails, the roofs of the out-buildings, and if a convenient opportunity offers, enters the barn, and picks up the refuse seeds. It seldom alights on trees, but occasionally on starting a flock, it will rise and settle on a near tree, in the manner of the common Snow Bird. 'This species keep in flocks, and when migrating, fly in close bodies and at a considerable elevation. On Mount Saddleback, one of the highest peaks in the State of Massachusetts, Mr. Edwards-from whom I have received the eggs-informed me, that in company with others, he found, in the month of July, eleven nests. They were placed on the ground, and formed chiefly of dry grass, lined with hair the eggs, four in number, are thirteen-sixteenths of an inch long, dull white, spotted and marked with reddish-brown, which mark. ings are darker and confluent at the great end. 


\title{
PLECTROPHANES LAPPONICA-LINN.
}

\author{
LAPLAND LARK BUNTING.
}

Lapland Longspur, Emberiza lapponica, Bonap. Syn.

Emberiza (Plectrophanes) lapponica, Lapland Bunting, Sw. \& Rich.

Lapland Longspur, Nutt. Man.

Lapland Longspur, Aud. Orn. Biog.

Specific Character-Bill dusky; hind claw slender, very acute, more arched than that of the preceding, and with the tarsi longer. Adult male with the head, chin, throat, and upper part of the breast velvet black, margined with white from the ears; a broad stripe of reddish-white from the upper eyelid on each side joins the white bordering the ears-and there are the rudiments of another in the middle of the bright chestnut nape ; rest of the upper plumage pale reddish-brown, each feather striped in the middle with blackish; coverts with two obsolete white bands; primaries hair-brown; their exterior edges whitish ; abdomen and under tail coverts dusky white; sides of the breast and flanks spotted with black; bill bright lemon-yellow, tipped with black; legs pitch black. The female differs in having the chin grayish, the black plumage of the head and breast edged with pale brown and gray, and the chestnut feathers of the nape fringed with dull white. In winter, (which is the only season its plumage is displayed to us, ) the upper parts are brownish-red, the feathers broadly streaked with black; lesser coverts, secondary coverts, and all the wing quills tipped with white; sides of the crown and cheeks dusky, between which passes a band of very pale reddish.brown; throat grayish-white; sides of the neck, fore part of breast, and sides of the body streaked with dusky; rest of the lower parts grayish. white. Length six inches, wing three and five-eighths.

In the winter of 1838 , several specimens of this bird were ob. served in the New York markets, having been shot on Long Island -but I am not aware that this species has ever before or since been met with in our section. In the Middle and Eastern States it is exceedingly rare, and only visits the United States in winter. 


\title{
GENUS EMBERIZA-LINN.
}

\author{
BLNTING.
}

[Bill short, robust, somewhat compressed, conic ; upper mandible rounded above, smaller and narrower than the lower; nostrils small, open, rounded, partially covered with the frontal feathers, tips accte, slighlly notched; head large, ovate; neck short; body plump ; wings and tail of moderate length, the latter emarginate; tarsi about equal to the middle toes, hind toe strongest, outer toe united at the base.]

\section{EMBERIZA AMERICANA-GMEL.}

\section{BLACK-THROATED BUNTING.}

Black-throated Bunting, Emberiza Americana, Wils. Amer. Orn.

Fringilla americana, Bonap. Syn.

Black-thruated Bunting, Nutt. Man.

Black-throated Bunting, Emberiza Americana, Akd. Orn. Biog.

Specific Character-Bill light blue, darker above, and much stouter than that of any species of this Genus. Adult with the fore part of the head greenish-olive; occiput, hind neck, cheeks, and sides of the neck, dark asli-gray; a band from the nostrils over the eye, and a band from the lower mandible yellow, terminating with white; chin white; throat black; the lower neck and middle of the breast yellow ; sides ash-gray ; abdomen white; back grayish-brown, the fore part streaked with black; lesser wing coverts bright chestnut; quills and tail feathers brown, margined with lighter. Female without the black on the throat, and with the general plumage duller. Length six inches and a half, wing three and a quarter.

About the middle of May the Black-throated Bunting arrives on Long Island from the South. It prefers the grain, grass and clover fields, where it continues its oft-repeated chirrup until the early part of August, then becoming silent. In the early part of September it migrates southward. The nest is built on the ground; the eggs are five,-white, speckled with black. 


\section{EMBERIZA GRAMINEA-GMEL.}

\section{BAY-WINGED BUNTING.}

Bay-winged Bunting, Emberiza graminea, Wils. Amer. Orn.

Fringilla graminea, Bonap. Syn.

Fringilla (Zonotorichia) graminea, Bay-winged Finch, Sw. \& Rich.

Bay-winged or Grass Finch, Fringilla graminea, Nutt. Man.

Grass Finch or Bay-winged Bunting, Fringilla graminea, Aud. Orn. Biog..

Specific Character-Lesser wing coverts bay; tail dark brown, the outer portion of the inner web of the outer feather white; a spot of the same color on the end of the next. Adult with the upper parts light grayish-brown, streaked with dusky; lower parts dull white; fore part of the neck and sides of the body streaked with dark brown, margined with grayish-white; lesser wing coverts bay, secondary and first row of small coverts tipped with dull white; tail dark brown, the larger portion of the outer feather white, with a similar spot on the end of the next feather. Length five inches and a half, wing three and one-eighth.

The favorite resort of the Bay-winged Bunting is the grassfields; sometimes it visits the ploughed fields in quest of insectsor, perched on a stake along the road-side, breathes forth its sweetly toned notes. The nest is placed on the ground, in which are deposited four, and sometimes five grayish-white eggs, shaded with reddish-brown. During the summer months it is abundant. A few remain with us throughout the year, but the majority migrate southward in autumn. 


\title{
EMBERIZA SAVANNA-BONAP.
}

\author{
SAVANNAH BUNTING.
}

\begin{abstract}
Savannah Finch Fringilla savanna, Wils. Amer. Orn. Fringilla savanna, Bonap. Syn.

Savannah Sparrow, Fringilla savanna, Nutt. Man. Savanuah Finch, Friugilla savanna, Aud. Orn. Biog.
\end{abstract}

Specific Character-A yellow line from the nostril over the eye; medial band the same color, but paler; shoulders of the wings white. Adult with the upper parts light grayish-brown, streaked with dusky; upper part of the head dusky brown, with a narrow pale yellow band; a line over the eye yellow; a line of dusky from the bill down the sides of the neck; a similar marking on the sides of the throat, which, with the fore neck, a portion of the breast, and sides of the body, are streaked with dusky; rest of the lower parts white; quills dark brown, the secondaries and their coverts broadly edged with lighter brown; tail feathers dark brown, edged with dull white. Length five inches and a half, wing two and five-eighths.

This species is found in all the Atlantic districts, and was observed by Mr. Audubon as far north as the coast of Labrador. $\mathrm{W}$ ith us it is quite common. It has a partiality for the high, dry lands, frequents the grass-fields and open grounds unincumbered with woods, and is very plentiful on the Hempstead Plains, over which section of country one can rarely pass, during summer, without meeting with this handsome Sparrow. Although not very familiar, it sometimes alights on the garden-fence, or, perched on the shrubbery near the house, it delivers its varied notes. In general it prefers the uplands, but sometimes it is seen along the sandy shores in quest of coleopterous insects. The nest is placed on the ground, formed almost entirely of dry grasses, selecting the finer blades for finishing the interior. The eggs are pale bluish, spotted with umber brown. 


\section{EMBERIZA PASSERINA-WILSON.}

\section{YELLOW-WINGED BUNTING.}

Yellow-winged Sparrow, Fringilla passerina, Wils. Amer. Orn. Fringilla passerina, Bonap. Syn.

Yellow-winged Sparrow, Fringilla passerina, Aud. Orn. Biog.

Specific Character-Bill very stout; loral band yellow; medial band dull yellowish-white; wing at shoulder bright yellow; tail emarginate, the feathers narrow and pointed. Adult with the upper part of the head dusky, intermixed with grayish-white; a ring round the eye and a band behind the eye of the samc color; medial band yellowish-white; a band from the nostrils to the eye yellow ; hind neck ash gray, intermixed with dusky; back brownish-black, marked with bright chestnut; quills and tail feathers dark brown, margined with dull white; inner secondaries and their coverts darker and more broadly margined; edges of the wings at flexure bright yellow; sides of the neck, breast, lower tail coverts, and sides of the body, pale yellowish-gray, with a few touches of dusky on the latter; throat grayish-white. Length four inches and three quarters, wing two and a half.

This species can be readily distinguished from the former by the difference in the coloring of the lower parts, which in this bird are pale yellowish-gray, those parts of the preceding being white, with the fore part of the breast and sides streaked with dusky, the yellow line over the eye more extensive, and the tail feathers are narrower and more pointed. The favorite resort of the Yellow-winged Bunting is the grass-fields-more especially the clover-where, sitting on a stone or stump, it is observed sitting for hours together, singing cheerfully and pleasantly. It is quite a common species, and was first introduced to notice by Wilson. The nest, which is formed of loose, dry grass, and lined with hair and fibrous roots, is placed on the ground; the eggs, five in number, are grayish-white, sprinkled with brown. 


\section{EMBERIZA HENSLOWII。}

\section{HENSLOW'S BUNTING.}

Henslow's Bunting, Emberiza Henslowii, Nuit. Man.

Henslow's Bunting, Emberiza Henslowii, Aud. Orn. Biog.

Specific Character-Bill very stout in proportion to the bird, which is at all times a specific distinction. Adult fith two black bands on the top of the head, with an intermediate yellowishbrown ; upper parts light yellowish-brown, streaked with brownish-black; the margins of the feathers on the back and scapulars light red; the edges of the wings pale yellow; lower parts light brownish-yellow, abdomen and throat paler; the sides of the body and sides of the neck, and upper part of the breast, streaked with black; quills dusky; primaries edged with brownish-yellow; secondaries with light red; tail feathers dusky, the outer margined with yellowish-brown, the middle more broadly with light red; bill very stout; wings short, tail feathers pointed. Length five inches, wing two and three-eighths.

This species was first described by $\mathrm{Mr}$. Andubon. He discovered it in Kentucky, opposite Cincinnati. He also speaks of it as being abundant in the State of New Jersey, and he likewise procured great numbers in South Carolina and Florida. On Long Island it is not abundant, but it is not so rare as is generally supposed. In general, it frequents the low, wet meadows, and passes most of its time on the ground among the tall grass, and is exceedingly difficult to flush, even when pursued with dogs; it will not fly until nearly within their reach, when it starts from the ground, moves on only a few yards, and again drops among the grass-and unless the gunner is expert, it is apt to escape. From the eagerness with which it is pursued by dogs, we may infer that it possesses considerable game effluvia

It is closely allied to the Yellow-winged Bunting, and from this circumstance may easily be overlooked by collectors. In other parts of the State of New York, it is not uncommon. Mr. Bell informs me that in Rockland county he has shot from ten to fifteen during one season, and saw as many more. 


\title{
EMBERIZA PUSILLA-WILSON.
}

\author{
FIELD BUNTING.
}

Field Sparrow, Fringilla pusilla, Wils. Amer. Orn.

Fringilla pusilla, Bonap. Syr.

Field or Rush Sparrow, Fringilla juncorum, Nutt, Man.

Field Sparrow, Fringilla pusilla, Aud. Orn. Biog

Specific Character-Bill light brownish-red; upper part of the head chestnut; a distinct band round the neck, the color bluish-gray, lighter in front; tail plain brown; both webs of the feathers margined with dull white. Adult with the upper part of the head chestnut red, similar markings on the neck, though much fainter; fore part of the back bright chestnut red, the feathers with central markings of dusky, and margined with yellowish-gray; loral space, a spot behind the eye, throat, and a band on the hind neck, pale bluish-gray; lower parts grayish-white, with a tinge of yellowishbrown on the sides of the neck, fore part of the breast and sides of the body; quills and tail feathers brown; secondary coverts dusky, tipped with white, as is the first row of small coverts. Length six inches, wing two and three-eighths.

About the middle of April, the Field Sparrow arrives from the South, where it passes the winter. It prefers pasture lands, dry grounds and corn-fields, and passes the most of its time on the ground in quest of seeds and insects, on which it subsists. The note of this abundant species is a simple chirrup. The nest is placed on the ground, at the foot of a bush or briar; the eggs are six in number, so closely speckled with reddish-brown as to appear altogether of that color. 


\title{
EMBERIZA SOCIALIS-WILSON.
}

\section{CHIPPING BUNTING.}

\author{
Chippirg Sparrow, Fringilla socialis, Wils. Amer. Orn. \\ Fringilla socialis, Bonap. Syn. \\ Chipping Sparrow, Fringilla socialis, Nutt. Man. \\ Chipping Sparrow, Fringilla socialis, Aud, Orn. Biog.
}

Specific Character-Bill black, brighter at the base of the lower mandible, at the nostril a white band passing over the eye; from the ridge of the upper mandible two black lines diverging toward the eyes; from the corner of the mouth a black band passing through the eye. In winter the color of the bill is lighter, the general markings more obscure. Adult with the upper part of the head bright chestnut red; fore part of the back streaked with dusky, bright chestnut, and yellowish gray; a ring round the neck; a band over the eye white; throat light bluish-gray, streaked with dusky; quills and tail dusky brown - the former margined with light red, the latter with yellowish-gray; two white bands on the wings; breast and sides pale gray, inclining to white. Young with the lower parts speckled with dusky. Length five inches and a quarter, wing two and three-eighths.

This, like the former species, is very generally known by the name of "Chipping Bird." It is rather more abundant than the preceding, and its habits more familiar. It frequents the orchards and gardens, and is plentiful on the fields and along the road-side; it visits the towns and villages, and during spring sings sweetly. Early in the month of May it builds its nest, which is placed in the fruit-trees in the garden or orchard, and sometimes in a cedar bush, exteriorly framed of fine dried grass, and lined with hair; the eggs, four or five in number, are of a bright greenish-blue color, slightly marked with dark and light brown spots. In the month of October it migrates southward, and returns to us in the latter part of March. 


\title{
EMBERIZA CANADENSIS-LATHAM.
}

\author{
CANADA BUNTING.
}

\begin{abstract}
Tree Sparrow, Fringilla arborea, Wils. Amer. Orn.
Fringilla Canadensis, Bonap. Syn.

Emberiza Canadensis, Tree Bunting, Sw. \& Rich.

Tree Sfarrow, Fringilla Canadensis, Nutt. Man.

Tree Sparrow, Fringilla Canadensis, Aud. Orn. Biog.
\end{abstract}

Specific Character-Upper mandible blackish brown; lower yellowish-red; upper part of the head bright chestnut red; tail rather long; both webs of all the feathers margined with white, the outer feathers more broadly margined and conspicuously tipped with white. Adult with the upper part of the head bright chestnut-red; sides of the head, neck, and fore part of the breast, pale bluish gray-the throat rather lighter, as is the band over the eye; rest of the lower parts grayish-white, with the sides tinged with yellowish brown; sides of the breast marked with reddish-brown; fore part of the back streaked with chestnut, yellowish-gray and dusky; rump pale yellowish-gray; quills dark brown, the inner secondaries darker, which, with their coverts, are broadly margined with lightred; tail feathers dark brown, margined with grayish white, as are the outer primaries; two distinct bands on the wing, formed by the tips of the secondary and first row of small coverts, which are white. Length six inches and a quarter, wing two and seven eightlıs.

This species visits us only in the winter, and retires to its breeding place at the North in the month of April. Its habits are very similar to the Snow Bird, with which it associates. According to Dr. Richardson, this species arrives in small flocks on the banks of the Saskatchewan in the third week in April, and after a short halt, proceeds farther north to breed. 


\section{GENUS NIPH压A-AUDUBON.}

\section{SNOW BIRD.}

[Bill short, rather small, conical, upper mandible a little broader than the lower, its dorsal line straight, slightly declinate at tip ; nostrils basal, roundish, concealed by feathers, tip acute; head broadly ovate; neck short ; body full; feet of moderate length; tarsı rather shurt, stout; toes rather strong-the hind toe stout, lateral equal ; wings rather short, curved, rounded; tail rather long, slightly emarginate.]

\section{NYPHÆA HYEMALIS-LINN.}

\section{COMMON SNOW BIRD.}

Snow Bird, Fringilla nivalis, Wils. Amer. Orn.

Fringilla hyemalis, Bonap. Syn.

Fringilla hyemalis, Black Finch, Sw. \& Rich.

Common Snow Bird, Fringilla Hudsonia, Nutt. Man.

Snow Bırd, Fringilla hyemalis, Aud. Orn. Biog.

Specific Character-Head, neck all round, back, fore part of the breast and sides grayish-black; abdomen white; wings and tail feathers black, the quills margined externally with dull white; the outer two tail feathers white-a spot of the same color on the third next to the shaft, extending an inch or more from the end of the inner web. Female with the plumage lighter, tinged with brown on the neck and head. Length six inches and a quarter, wing three and one-eighth.

A bout the middle of October these birds appear on Long Island in large flocks. They resort to the open, neglected fields, and are observed along the roadside, feeding on the seeds of various species of rank, uncultivated plants. It is an exceedingly numerous 
species, and in open winters they remain with us in large numbers until the latter part of April. In severe weather the large majority retire towards the South--though during the coldest weather, even when the ground is covered with deep snow, the trees loaded with ice, and scarcely a vestige of vegetation to be seen, a few remain; at such times they become quite tame, frequent the door-yard, visit the out-buildings, attend the feeding of the cattle for the purpose of collecting the scattered seed, and in addition to their scanty subsistence, approach the threshold, and by their piteous manner ask for charity, when they could join their kindred in more hospitable regions, where food is abun. dant, and independently obtained.

The Snow Bird spends much of its time on the ground; it also alights on trees and fence-rails, and like the Chipping Bunting and other familiar species, visits the towns and villages, and is not unfrequent in the private gardens and public grounds of our large cities. When food is readily obtained, it gets quite fat, and is shot and caught in traps of various kinds, and sent to market. It meets with ready sale, and by many persons is considered excellent.

Usually by the first of May, all of this species have departed from the Island, its northward migrations extending to the Fur countries, where it is said that the majority pass the summer. A few have been found breeding on the Cattskill Mountains, and in the woods at Greenbush, opposite Albany, as well as in the more immediate vicinity of that city, 


\title{
GENUS SPIZA-BONAP.
}

\author{
PAINTED BUNTING.
}

[Bill short, stout, conical-upper mandible declinate at the tip, slightly notched; nostrils roundish, partially concealed by feathers; head of moderate size; neck short; body rather full; wings and tail of moderate length, the latter emarginate.]

\section{SPIZA CYANEA-WILSON.}

\section{INDIGO PAINTED BUNTING.}

Indigo Bird, Fringilla cyanea, Wils. Amer. Orn.

Fringilla cyanea, Bonap. Syn.

Indigo Bird, Nutt. Man.

Indigo Bird, Fringilla cyanea, Aud. Orn. Biog.

Specific Character-A black line on the under part of the lower mandible, extending its entire length. Adult male blue, tinged with verdigris green; quills and tail feathers dusky, edged with green. ish blue. Female yellowish-brown above, paler beneath. Length five inches and a quarter, wing two and a half.

In almost all our birds, the plumage of the male is brighter than that of the female, but there is not in general so great a discrepancy as in the present species. The male Indigo Bird is rendered conspicuous by its rich blue livery, while the female, more humbly attired in plain yellowish-brown, is scarcely noticeable. Not only are the males of almost every species more gaily dressed, but with our singing birds they also excel in song. It has frequently occurred to me, that Nature, who does nothing without a cause, has, for the safety of the females, rendered them less attractive. The male, excelling both in plumage and song, is more sought after as a mat- 


\section{(111)}

ter of ornament by collectors, as well as by persons who ensnare them for cages; while the female, from its humble attire and quiet manners, is left to rear its brood in safety.

The Indigo Bird arrives on Long Island in the month of May. and retires southward in the month of September. It frequents the gardens and fields, and is often seen perched on fences by the roadside; or mounted on the higher branches of a small tree, it warbles forth its charming notes, some of which are quite loud, while * others are performed on so low a key as to be scarcely audible even at a short distance.

With us it is a common species, and is very generally distributed throughout the United States during summer. About the end of June it commences building its nest, which is usually placed in some low bush or shrub; the eggs, usually five in number, are of a bluish color. It is a sprightly bird, and feeds chiefly on insects and seeds. 


\title{
GENUS AMMODRAMUS-SWAINSON.
}

\author{
SHORE FINCH.
}

[Bill rather long, a little shorter than the head, rather thick at the base, tapering-upper mandible curving toward the tip, slightly notched, projecting beyond the lower, and a little declinate; nostrils partially covered; head of moderate size; neck short; body rather slender; wings short, rounded; tail of moderate length, of twelve narrow pointed feathers; tarsi longer than the middle toe-anterior toes rather long; claws small-hind toe stout, claw very long, acute.]

\section{AMMODRAMUS MARITIMUS-WILSON.}

\section{GRAY SHORE FINCH.}

Sea side Finch, Fringilla maritima, Wils. Amer. Orn.

Fringilla maritima, Bonap. Sy 1 .

Sea-Side Finch, Fringilla maritima, Nutt. Man.

Sea-side Finch, Fringilla maritima, Aud. Orn. Biog.

Specific Character-Upper parts brownish-gray, lower parts lighter ; a band from the nostril over the eye, and the edge of the fore part of the wing yellow; tail graduated, the feathers pointed. Adult with a narrow band of yellow from the nostril over the eye; upper parts brownish-gray, with two darker bands on the head; upper plumage tinged with olivaceous; quills and tail feathers dark brown, edged with greenish; edges of the wings yellow; throat grayish-white, the sides streaked with dusky; a whitish band from the base of the lower mandible down the sides of the neck; lower portion of fore neck, with the breast, and sides of the body, light bluish-gray, streaked with dark brown and tinged with olivaceous; abdomen dull white. Length eight inches, wing two and three-eighths.

This species is familiar to all our sportsmen who practice bayshooting. During the summer months it is common on all the necks of land along the sea coast, and abundant on the low Islands in the Great South Bay of Long Island. It is seen climbing up the rank sedge in search of insects and seeds, and it frequents the shoals for the purpose of procuring small shrimps and other marine food, whence its flesh derives an unpalatable flavor. 


\title{
AMMODRAMUS CAUDACUTUS-LATH.
}

\author{
BUFF-BREASTED SHORE FINCH.
}

Sharp-tailed Finch, Fringilla caudacuta, Wils. Amer. Orn.

Fringilla caudacuta, Bonap. Syn.

Shore Finch, Fringilla littoralis, Nutt. Man.

Sharp-tailed Finch, Fringlla caudacuta, Aud. Orn. Biog.

Specific Character-A band on the sides of the head and sides of the neck light yellowish-red; tail graduated, the feathers more abruptly pointed than the preceding. Adult with the upper part of the head dusky brown, with a central bluish-gray band; a broad band of light yellowish-red from the nostril over the eye, continuing beyond the head; a similar band from the base of the lower mandible, curving down the sides of the neck, meeting the upper band at its termination; cheeks bluish-gray; hind neck of the same color, and having a central spot of olivaceous brown; back brown, tinged with gray, with a few dusky spots; some of the feathers on the fore part of the back edged with white; quills dark brown, the inner seconda ries and their coverts broadly margined with reddish-brown, and tipped with dull yellowish-white; tail brown, the feathers pointed and margined with grayish-olive; throat white, its sides streaked with dusky, as are the breast and sides of the body, which are tinged with pale yellowish-red, lower tail coverts of the same color; rest of the lower parts white. Length five inches, wing two and one quarter.

This species-less plentiful than the former-inhabits the same localities, and in their general habits are closely allied. According to Mr. Audubon, both species winter among the salt marshes in South Carolina 


\title{
AMMODRAMUS PALUSTRIS-WILSON.
}

\author{
MARSH SHORE-FINCH.
}

Swamp Sparrow, Fringilla palustris, Wils. Amer. Orn

Fringilla palustris, Bonap. Syn.

Swamp Sparrow, Fringilla Georgiana, Nutt. Man.

Swamp Sparrow, Fringilla palustris, Aud. Orn. Biog.

Specific Charucter-Upper parts yellowish-brown, broadly marked with black, flanks more faintly streaked with the same; on either side of the throat two black bands; bill and fore part of the breast ash gray. Adult with the upper part of the head deep chestnut-red; a band from the nostril over the eye, becoming broader behind the eye, and continuing the entire length of the head, grayish-blue, tinged with yellow; upper parts yellowish-brown, marked with black more conspicuously on the fore part; quills brown, edged with dull red, as are the tail feathers; inner secondaries and their coverts darker, and broadly edged with yellowish-red; cheeks dark brown; throat grayish-white, the sides streaked with dusky; fore neck and fore part of the breast pale bluish-gray; sides of the body yellowish-brown; abdomen grayish-white. Young with the upper part of the head streaked with black, with a narrow central bluish-gray line. Length five inches, wing two and three-eighths.

During the summer months, we find this species in low, swampy situations, skulking among the sedgy borders of creeks, subsisting on seeds and insects. It constructs its nest on the ground, among the rank weeds; the eggs, from four to five in number, are dull white, spotted with reddish-brown. During the winter, it inhabits the swamps and margins of water courses in the Southern States. 


\section{GENUS LINARIA-RAY.}

LINNET.

[Bill short, stout at the base, compressed toward the end, and tapering to an acute point-nostrils concealed by recumbent feathers, advancing in some species about half-way the length of the bill; head rocnded, rather small; neck short; wings and tail rather long, the latter deeply emarginate-tarsi short-feet and toes rather stout.]

\section{LINARIA PINUS-WILSON.}

\section{PINE LINNET.}

Pine Finch, Fringilla pinus, Wils. Amer. Orn.

Fringilla pinus, Bonap Syn.

Pine Finch, Fringilla pinus, Nuit. Man

Pine Finch, Fringilla pinus, Aud. Orn. Biog.

Specific Character-Bill at base stout, tapering to a sharp point ; tail deeply emarginate. Adult with the upper parts yellowish-gray, streaked with black; feathers on the rump margined with light yellow; lower parts grayish-white, streaked all over with brownish black; the fore neck tinged with lighter brown; tail at base yellow, toward the end blackish-brown; both webs of the basal parts of quills, excepting the outer three, yellow, and the yellow margin wanting on the first. Length four inches and three quarters, wing two and seven-eighths.

At some seasons, this species is very abundant with us; again, it does not occur, or at most in very small numbers, for several years. It breeds at the North, and only visits us in autumn. Its manner of flying is not unlike that of the common Goldfinch. It frequently alights on the birch trees, from the cones of which it extracts a portion of its sustenance. It associates in large flocks, and in general prefers the open grounds, where it is seen climbing among the rank weeds - often hanging head downward, pecking with its bill, much in the manner of the Titmouse. Sometimes it is observed along the margins of small streams, hopping among the alder-bushes. During winter it resorts to the Pines, the seeds of which, at that season it feeds on. 


\title{
LINARIA MINOR-RAY
}

\section{LESSER REDPOLL LINNET.}

\author{
Lesser Redpoll, Fringilla linaria, Wils. Amer. Orn. \\ Fringilla linaria, Bonap. Syn. \\ Linaria minor, Lesser Redpoll, Sw. \& Rich. \\ Lesser Redpoll, Nutt. Man. \\ Lesser Redpoll, Fringilla linaria, Aud. Orn. Biog.
}

Specific Character-Bill short; much less than the preceding; tail deeply emarginate, or slightly forked. Adult male with the upper part of the head crimson; sides of the neck, fore part of the breast and flanks, carmine; upper parts deep brown, streaked with pale yellowish-brown, the feathers on the rump lighter, and tipped with carmine; wings and tail brown, edged with yellowish-brown, secondary and lesser coverts tipped with white; a band on the forehead, loral space and throat brownish black; lower parts white, deeply tinged with rose color on the breast, paler on the abdomen, rump and lower tail coverts; sides of the body streaked with dusky. Female with less red on the head; the throat brown; the rose color on the lower parts wanting. Young, without any red marking; upper parts blackish-brown; lower parts dull white: Length five inches and a quarter, wing three.

This is another of those inhabitants of the North that seldom visit us except in winter. It assaciates in flocks, feeds on seeds, and when in good condition is esteemed a delicacy. 


\title{
GENUS CARDUELIS-CUVIER.
}

\author{
GOLDFINCH.
}

[Bill short, stout, conic, points acute-nostrils concealed with feathers, space between broad-head rather small, roundish-neck short-body rather fullwings rather long - tail emarginate-tarsi rather short-toes slender, hind too strongest-claws compressed, acute.]

\section{CARDUELIS TRISTIS-LINN.}

\section{A.MERICAN GOLDFINCH.}

American Goldfinch, Fringilla tristis, Wils. Amer. Orn.

Fringlla tristris, Bonap. Syn.

Carduelis Americaua (Edwards) American Goldfinch, Sw. \& Rich.

Yellow Bird, or American Goldfinch, Nutt. Man.

American Goldfinch, Fringilla tristris, Aud. Orn. Biog.

Specific Character-Wings and their coverts black, margined and tipped with white; tail also black, the inner webs of the feathers toward their ends largely spotted with white. Adult male, in summer, with the upper part of the head, wings, and tail black, the inner quills margined with white-secondary coverts tipped with the same; tail emarginate; a patch of white on the inner webs of all the feathers; lower tail coverts white; rest parts bright yellow. Female without the black on the head; upper parts brownish-olive, darker on the back; lower parts grayish-yellow, lighter on the abdomen. Male in winter similar to the female. Length four inches and a half, wing two and seven-eighths. 
The American Goldfinch, or as it is more familiarly termed, "Yellow Bird," is generally distributed over the United Statesand in summer is found in the high northern latitudes. It resides on Long Island throughout the year; it frequents the fields, orchards, and gardens, subsisting on tender plants and seeds, and seems particularly fond of the seeds of the common thistle, Hempseed, chickweed, and other tender plants. It constructs its nest in the low branches, among the thickly clustered leaves, usually selecting a bushy tree, standing at a distance from any other, in the middle of a lot, or other lonely situation. The eggs, five in number, are dull white.

It is often caught in trap-cages, and exposed for sale in the markets. It bears confinement well, and is much admired for its beau. tiful plumage and agreeable song, which in some instances is but little inferior to that of the Canary. It lives in society, and when flying about, the golden yellow and deep black colors render it conspicuous and pleasing. Its flight is performed in an undulating manner, similar to that of the Woodpecker. 


\title{
GENUS FRINGILLA-LINN
}

\author{
FINCH.
}

[Bill short, stout, conical, pointed-upper mandible with the ridge straight ; nostrils concealed by feathers; head rather large; neck short; body compact : wings of moderate length; tail of moderate lengtb, slightly emarginate; tarsi of moderate length - hind toe strongest.]

\section{FRINGILLA ILIACA-MERREM.}

\section{FOX-COLORED FINCH.}

Fox-colored Sparrow, Fringilla rufa, Wils. Amer. Oro.

Fringilla iliaca, Bonap. Syn.

Fringilla (Zonotrichia) iliaca, Sw. \& Rich.

Ferruginous Finch, Fringilla iliaca, Nutt. Man.

Fox.culored Sparrow, Fringilla iliaca, Aud. Orn. Biog.

Specific Character-The conspicuous reddish markings on the lower paris, and the uniform bright reddish color of the upper tail coverts and tail are at all times a specific distinction. Adult with the upper parts light red, intermixed with light bluish on the upper part of the head and hind neck; a band of white anterior to the eye; lower parts white; the throat and foreneck marked with small spots of light red, the spots on the breast larger, with the sides of the body broadly streaked with the same color; tail light red, the color more uniform and lighter than that of the back; quills brown, margined externally with 
light red. Length seven inches and a half, wing three and three-eighths.

This species arrives among us from the woody districts of the Fur Countries, (where it breeds, ) in the latter part of October. Although it generally frequents low, sheltered thickets, it occasionally visits the gardens of the city, associates in small parties, and is fond of scratching among the dried leaves on the ground, much in the manner of the Towhe Bunting.

It is quite tame and unsuspicious. I have known instances in which it has allowed itself to be approached and killed with sticks. During its visits among us, it utters a simple chirp.Dr. Richardson says, that at its breeding place, during the season of incubation, the male sits near his mate, and sings cheerfully and pleasantly. 


\section{FRINGILLA MELODIA-WILSON.}

\section{SONG FINCH.}

Fringilla melodia, Wils. Aner. Orn.

Fringilla melodia, Bonap. Syn.

Common Song Sparrow, Fringilla melodia, Nutt. Man.

Song Sparrow, Fringilla melodia, Aud. Orn. Biog.

Specific Character-A curving black band on the side of the neck; breast and sides broadly streaked with dark brown, shaded with red, the feathers on the fore part of the breast more broadly marked, forming a conspicuous spot. Adult with the upper parts yellowish-gray, streaked with brownish-black and brownish-red; upper part of the head reddish-brown, streaked with black, with a medial band of grayish-blue; a similar band on the sides of the head, becoming much broader as it passes behind the eye-directly below this band a line of dusky brown; a similar line from the base of the lower mandible on the sides of the neck ; throat white, with a broad band of dusky on each side; lower parts white; fore part of the breast and sides of the body streaked with reddish and dusky brown; quills dark brown-tail feathers lighter. Length six inches, wing two and five-eighths.

This, one of our most numerous Sparrows, is distributed throughout the United States. Although plainly attired, it is much admired for its agreeable song, which commences earlier in spring, and continues later in autumn, than that of any of our songsters. In winter it inhabits, in company with other species, the sheltered swamps in the Southern States. It breeds in various parts of the Union, constructing its nest on the ground, sometimes in a low bush, and rears two broods in a season; it prefers low, swampy situations, and feeds on seeds, berries, and insects. . A few remain with us during winter; at this period it becomes quite familiarapproaches the door-yard, and sometimes enters the farm-house, picking up crumbs and whatever articles of food chance may throw in its way-and at that inclement season, on bright mornings, mounted on a stake or brush pile, it sings cheerfully. 


\title{
FRINGILLA PENNSYLVANICA-LATH.
}

\author{
WHITE-THROATED FINCH.
}

White-throated Sparrow, Fringilla albicollis, Wils. Amer. Orn.

Fringilla Pennsylvanica, Bonap. Syn.

Fringilla (Zonotrichia) Pennsylvanica, White-throated Finch, Sw. \& Rich.

White-throated Sparrow, Fringilla Pennsylvanica, Nutt. Man.

White-throated Sparrow, Fringilla Pennsylvanica, Aud. Orn. Biog.

Specific Character-A broad white patch on the throat. Adult male with a band of yellow from the nostril to the eye, changing to white as it passes over the eye, fading into dull brownish-white as it continues to the occiput, bordered above with a broad band of black; middle space on the upper part of the head white, changing into brownish-white on the hind neck; fore part of the back bright bay, streaked with dusky and reddish-yellow; rump yellowish gray; primaries brown, edged with yellowish-gray ; secondaries and their coverts broadly margined with bright red; secondary coverts, and first row of small coverts, tipped with dull white; cheeks, sides of the neck, and a large portion of the breast, ash gray; throat white; rest of the lower parts grayish-white, the sides tinged with yellowish-gray ; tail feathers brown, edged with rufous. Length six inches and a half, wing two and seven-eighths. Female with the colors duller, and rather smaller.

This large and handsome Sparrow visits us from the North. It associates in flocks, and frequents the borders of swampy thickets. It does not breed on Long Island, merely visiting us in autumn. It frequents similar situations, and is usually found in company with the preceding. 


\title{
FRINGILLA LEUCOPHRYS-GMEL.
}

\author{
WHITE-CROWNED FINCH.
}

White-crowned Bunting, Emberiza leucophrys, Wils. Amer. Orn.

Fringilla leucophrys, Bonap. Syn.

Fringilla (Zonotrichia) leucophrys, White-crowned Finch, Sw. \& Rich.

White-crowned Bunting, or Fınch, Nutt. Man.

Whitc-crowned Sparrow, Fringilla leucophrys, Aud. Orn. Biog.

Specific Character-Crown white, broadly bordered in front and at the sides with black; over the eye a white band, below which, passing through the eye, a black band. Young with the crown bordered with reddish-brown, and the white marking so conspicuous on the crown of the adult, faintly developed. Adult male with the crown white; a band passing behind the eyes, meeting on the occiput, white, bordered above and below with broad bands of black; cheeks, sides, fore part of the neck, and a large portion of the breast, ash-gray; throat and abdomen grayish-white ; sides and lower tail coverts yellowish-brown; fore part of the back streaked wth reddish-brown and yellowish-gray; rump light yellowishbrown ; quills dark brown; primaries edged with yellowish-gray; secondaries and their coverts with yellowish-red; secondary and first row of small coverts tipped with white; tail feathers brown. Length seven inches and a half, wing three and a quarter.

In the Middle States this well-marked Sparrow is quite rare. In the Western States it is more abundant, and has been found quite plentiful in Missouri, in the vicinity of St. Louis. It is very gentle, allows of near approach, and is usually observed along the roads and farm-houses.

"It breeds in all parts of the Fur countries, arriving about the middle of May, and departing early in September to the northern parts of the United States, where it winters.-Fauna Boreali Amer. icana, part second, page 255. 


\section{GENUS PIPILO-VIEILL.}

\section{GROUND FINCH.}

[Bill short, stout, conical, compressed towards the end, slightly notchedbristles at the base, narrower than the head; head ovate, neck short, body rather full ; wings of moderate length, rounded; feet stout, toes rather longtarsi longer than the middle toes.]

\section{PIPILO ERYTHROPHTHALMUS-LINN.}

\section{TOWHE GROUND FINCH, OR TOWHE BUNTING.}

Towhe Bunting, Emberiza erythrophthalma, Wils. Amer. Orn.

Fringilla erythrophthalma, Bonap. Syn.

Ground Robin, or Towhe Finch, Fringilla erothrophthalma, Nutt. Man.

Towhe Bunting, Fringilia erythrophthalma, Aud. Orn. Biog.

Specific Character-Sides of the body and lower tail coverts reddish-brown; terminal portion of the outer three tail feathers, and a band about midway the primaries on their outer webs, white. Adult with the head, neck all round, upper portion of the breast, and upper parts black; a spot of white on the outer webs of the primaries toward their bases; a large patch of white on the outer tail feathers, diminishing on the second and third; the rest plain black; sides of the body reddish-brown, lower tail coverts much paler ; rest of the lower parts white. Young with the upper parts dull reddish-brown, streaked with brownish-black; lower parts yellowish-gray, streaked on the fore neck, fore part of the breast, and sides; with dusky; abdomen yellowish-white; wings and tail the same as the adult. Length of adult eight inches and a half, wing three and three-eighths.

This common bird is familiarly known by the appellations of "Ground Robin," "Swamp Robin," and "Chewink." 
'The Towhe Bunting makes its appearance among us in the lat ter part of April. It generally keeps in pairs, and at this season frequents the shady part of the woods, forming its nest on the ground, among the dried leaves. The eggs, from four to five in number, are pale flesh-color, spotted with reddish-brown.

During the warmest part of the summer its song ceases, and it retires to the sheltered thickets. In the month of September, its loud note, resembling the syllables "Tow-he," is again heard in the woods, where it continues until about the middle of October, when it migrates to a more temperate climate. In the early part of February I found it abundant in Louisiana.

The Towhe Bunting passes a large portion of its time on the ground, scratching among the leaves, [much in the manner of the barn-yard fowl,] for seeds and gravel. When not thus employed, it is seen on the lower branches, spreading and erecting its tail, or sporting about from tree to tree, in company with its mate, seemingly so much attached to each other, that when accident befals either, the survivor evinces its unhappiness by causing the woods to echo with its loud note, repeated in a wild and hurried manner. 


\title{
GENUS ERYTHROSPIZA-BONAP
}

\author{
PURPLE FINCH.
}

[Bill short, robust, bulging, conical-upper mandible slightly notched at the tip; nostrils large, rounded, partly covered with feathers; head large, ovate : neck short; wings of moderate length; tail of moderate length, and deeply emarginate-tarsi short, slender.]

\section{ERYTHROSPIZA PURPUREA-GMEL.}

\section{CRESTED PURPLE FINCH.}

Purple Finch, Fringilla purpurea, Wils Amer. Orn.

Purple Finch, Bonap. Syn.

Fringilla purpurea, Crested Purple Finch, Sw. \& Rich.

Purple Finch Fringilla purpurea, Aud. Orn. Biog.

Specific Character-Bill short, stout, conical ; along the ridge half an inch; gap, to the point of the upper mandible five-eighths; breadth of lower mandible at base, three-eighths; tarsi five-eighths; tail emarginate. Adult male with general color of the plumage dark crimson, which is spread over the head, back, upper tail coverts, neck, breast, and sides of the body; abdomen and lower tail coverts white; wings and tail feathers dark brown-1ore part of the back marked with the same. Female, with the upper parts yellowish brown, the central parts of the feathers darker; wings and tail dark brown, edged with dull white, the central parts of the feathers dusky; abdomen white, without the crimson markings, [so conspicuous in the male,] on any part of the body. Young male similar to the female. Length six inches, wing three and and oneeighth. 
This is another of those birds that arrive from the north in autumn, and remain with us during winter. They associate in flocks and frequent the pines and cedars, the seeds and berries of which they are partial to; and they also seem to be very fond of the seeds of the sycamore. During some seasons they are quite abundant on Long Island, and are sometimes collected in large parties, flying so high in the air, that unless you recognize their peculiar note, it would be difficult to determine to what species they belong. They are frequently taken in trap-cages, and by those persons who are acquainted with the delicate flavor of their flesh, they are also shot for the table. In the early part of spring they resort to the orchards, and feed on the buds of the fruit trees. About the middle of May they leave for their summer residence at the North. Occasionally a few are seen with us during the summer, but their nests I have never seen. 


\title{
GENUS CORYTHUS-CUVIER
}

\author{
PINE FINCH.
}

[Bill short, robust, bulging at the base, conical, acute-upper mandible with its dorsal line very convex-nostrils wholly covered with recumbent feathershead rather large-neck short, full-body stuut, elongated-wings of moderate length, pointed - tail rather long, deeply emarginate-tarsi short, compressedfeet ard toes stout, rough.]

\section{CORYTHUS ENUCLEATOR-LINN.}

\section{PINE GROSBEAK.}

Pine Grosbeak, Loxia enucleator, Wils. Amer. Orn.

Pyrrhula onucleator, Bonap. Syn.

Pyrrhula (Corythus) enucleator, Pine Bullfinch, Sw. \& Rich.

Pine Grosbeak or Bullfinch, Nutt. Man.

Pine Grosbeak, Phyrrhula enucleator, Aud. Orn. Biog.

Specific Character-Bill black, strong, upper mandible curving over the lower; primaries edged with white; secondaries more broadly edged with the same; the outer webs of the secondary coverts toward their ends broadly margined and tipped with white; the tips of the lesser coverts also white; tail deeply emarginate. Adult with the head, neck all round, breast, fore part of back, and rump carmine; the feathers on the fore part of the back have central black markings; wings blackish-brown; the primaries edged with reddish; the secondaries broadly edged with white; secondary and first row of small coverts tipped with reddish-white; tail-feathers blackish-brown, margined with reddish; abdomen and lower tail coverts light gray. Female with the upper part of the head, hind neck, and rump, yellowish-brown-deeper on the latter; back brownish-gray; wings and tail dark-the former edged with white, secondary coverts and firsi row of small coverts tipped with the same; lower parts ashy-gray, tinged with yellow; abdomen and lower tail coverts lighter. Length nine inches, wing five. 
In the autumn of 1827 , large flocks of Pine Grosbeaks visited Long Island, Hoboken, and various places in the lower parts of New Jersey and New York. Since that period until the present year, I have not seen or heard of its occurring on Long Island. In the interval, a few have been observed in Rockland County, in which section, as with us, it was quite common during the month of January of the present year. I first met with them while making an excursion in Rockland, in company with the Messrs. Bell, on the second day of January. The ground was covered with a deep snow, on which was lying, under a group of cedar trees, a large quantity of berries and small twigs, which we supposed had been placed there by the Robin, or some other winter resident; but on advancing to another cluster of trees, we discovered that their work had acquired a great acquisition by the presence of a large flock of Pine Grosbeaks-which, however, were all young birds, as were all those that we fell in with during the day. Although large numbers were during the winter observed in the vicinity of New York, very few adults were procured. From this circumstance we are inclined to the opinion, that the adult only visits the lower part of the State of New York in severe winters. It is very gentle, and seems to be unaccustomed to the report of the gun. When fired into the survivors fly to a neighboring tree, and again allow you to approach quite near. I have remained for minutes together within a few feet of the tree, amusing myself by watching its vigorous manner when engaged in collecting food-which consists chiefly of cedar berries. It is a robust bird, and is furnished with a strong bill_and when feeding, scatters the clustered fruit in all directions. It is said to possess considerable musical talent—but with us, during winter, its song is reduced to a simple chirp. Dr. Latham observes they are found at Hudson's Bay-that they make their nest in trees at a small height from the ground, composed of sticks, lined with feathers-laying four white eggs. 


\title{
GENUS LOXIA-LINN.
}

\author{
CROSSBILL.
}

[Bill higher than broad at the base, much compressed toward the end-upper mandible rather lorg, projecting considerably beyond the lower, decurred-lower mandible recurved, crossing each other, tips acute-nostrils covered with recumbent feathers-head rather large--neck short-body compact-wings mod=erate-tail emarginate.]

\section{LOXIA CURVIROSTRA-LINN}

\section{COMMON CROSSBILL.}

\author{
American Crossbill, curvirostra Americana, Wils. Amer. Orn. \\ Loxia curvirostra, Bonap. Syn. \\ Common Crossbill, Nutt. Man. \\ Common Crossbill, Loxia curvirostra, Aud. Orn. Biog.
}

Specific Character-Bill very strong; wings without bands.Adult male bright red, the wings and tail feathers blackish-brown. Female with the upper parts grayish-brown, tinged with green; lower parts pale grayish-yellow; wings blackish-brown. Length seven inches, wing three and a half.

On Long Island this species is by no means common. During winter a few visit us from the North. Its favorite resort is the pine forest, and it is generally observed on the tops of the tallest trees. Its food consists chiefly of seeds which it extracts from the cones of the pine, for which purpose its strong and singularly formed bill is well adapted. 


\title{
LOXIA LEUCOPTERA-GMEL.
}

\section{WHITE-WINGED CROSSBILI,}

\author{
White-winged Crossbill, Loxia leucoptera, Wils. Amer. Orn. \\ Loxia leucoptera, Bonap. Syn. \\ White-winged Crossbill, Loxia leucoptera, Bonap. Amer. Orn. \\ Loxia leucoptera, White-winged Crossbill, Sw. \& Rich. \\ White-winged Crossbill, Loxia leucoptera, Nutt. Man. \\ White-winged Crossbill, Loxia leucoptera, Aud. Orn. Biog.
}

Specific Character-Bill slender in comparison with that of the preceding species; on the wings two white bands. Adult male with the head and neck all round, the lower parts and rump carmine; wings and tail coverts black, as are some of the feathers on the fore part and middle of the back; two white bands on the wings, formed by the secondary and first row of small coverts; secondaries also tipped with white; primaries and tail feathers narrowly edged and tipped with dull white. Female with the upper part of the head and hind neck grayish-yellow, spotted with dusky; fore neck, breast, and rump, reddish-yellow; abdomen and sides gray, streaked with dusky; wings same as the male, with the back dusky. Length six inches and a half, wing three and three quarters.

In this locality this species is not as frequently observed as the preceding, in the general habits of which it resembles. Like the former, it prefers the northern part of the cortinent, and only resorts to our milder climate when driven by severe weather.

"This Crossbill inhabits the dense white spruce forests of the fur countries, feeding principally on the seeds of the cones. It ranges through the whole breadth of the continent, and probably up to the 68th parallel, where the woods terminate, though it was not observed by us higher than the 62d. It is mostly seen on the upper branches of the trees, and when wounded, clings so fast that it will remain suspended after death. In September it collects in small flocks, which fly from tree to tree, making a chattering noise-and in the depth of winter it retires from the coast to the thick woods of the interior." - Fauna Boreali Americana, part second, page 263. 


\section{GENUS PITYLUS-CUVIER}

\section{CARDINAL.}

[Bill shor, higher than broad, tapering, robust, slightly notched-nostrils cc vered with the frontlet feathers, bristles at the base-head furnished with long erect feathers-neck short-wings of moderate length, rounded-tail long, much rounded-tarsi rather short-toes moderate-claws rather slender-hind toe and claw stoutest.]

\section{PITYLUS CARDINALIS-LINN.}

\section{CARDINAL GROSBEAK.}

Cardinal Grosbeak, Loxia cardinalis, Wils. Amer. Orn.

Fringilla cardinalis, Bonap. Syn.

Cardinal Grosbeak, or Red Bird, Fringilla cardinalis, Nutt. Man.

Cardinal Grosbeak, Fringilla cardinalis, Aud. Orn. Biog.

Specific Character-Head crested; loral space, a band round the bill and the throat black. Adult male with the general plumage vermilion, upper parts rather duller; the webs of the quills brown; bill red; loral space, a band round the base of the bill, and the throat black; tail long and rounded. Female with a slighter crest ; upper parts deeply tinged with olive, the lower grayish-yellow; rest parts much duller than the male. Length eight inches and a half, wing three and three quarters.

This species, more abundant in the Southern States, is with us a regular summer visiter. It generally keeps among the low bushes, though occasionally its loud and varied notes are delivered from the higher branches. It frequents the borders of streams, as well as the gardens and corn-fields, the latter supplying it with a large portion of its subsistence. It is taken in trap-cages, and continues its song during confinement, and with proper care will live many years, but does not retain the brilliant color so much admired when roving through its native haunts. 


\title{
GENUS COCCOBORUS-SWAINSON
}

\author{
SONG GROSBEAK.
}

[Bill rather short, extremely robust, almost as broad as the head, and somewhat compressed, tapering to a point-upper mandible considerably smaller than the lower-wings of moderate length, pointed-tail slightly emarginate, of moderate length.]

\section{COCCOBORUS LUDOVICIANUS-LINN.}

\section{ROSE-BREASTED GROSBEAK.}

Rose-breasted Grosbeak, Loxea rosea, Wils. Amer. Orn. Fringilla ludovicianus, Bonap. Syn.

Coccothraustes ludoviciana, Rose-breasted Grosbeak, Sw. \& Rich. Rose-breasted Grosbeak, Fringilla ludoviciana, Nutt. Man.

Rose-breasted Grosbeak, Fringilla ludoviciana, Aud. Orn. Biog.

Specific Character-Bill short, extremely robust; wings spotted and barred with white; second and third quills about equal and longest, first shorter than the fourth; length of tarsi fifteen-sixteenths of an inch. Adult male with the head, neck, fore part of back, wings and tail black; first row of small coverts, and a few of the secondary coverts, and secondaries, tipped with white; a large patch of white on the primaries toward their bases; a patch of white on the inner webs of the outer three tail feathers, the rest tipped with the same; upper tail coverts black, tipped with white; fore part and middle of the breast, and under wing coverts, carmine, rest of the lower parts white. Female with the upper parts 
light yellowish-brown; a medial band of yellowish-white over the crown; a brighter band over the eyes; secondary and first row of small coverts tipped with yellowish-white, a few spots of the same on the secondaries; lower parts dull white, tinged with yellow ; the breast and sides of the body streaked with dusky; under wing coverts pale yellow ; tail feathers light brown, without spots, margined and tipped with dull white. Length seven inches and three quarters, extent four and one-eighth.

On Long Island this elegant species is not very common. It arrives among us in the month of May, and generally keeps in the woods. The "pin-oak" and "pepperage" trees seem to be its favorite resort. During spring it is frequently seen hanging, like the Titmouse, from small trees, picking at the young and tender buds. At noon-day it retires to the sheltered parts of the woodswhere perched about midway on the trees, it warbles forth its soft, clear, and sweet notes, which are delivered on so low a key that the sounds seem to come from a distance; when, on looking attentively through the rich foliage, you discover the charming songster but a few yards from you.

In autumn it retires to a more temperate climate. 


\title{
GENUS PYRANGA-VIEILL
}

\author{
TANAGER.
}

[Bill short, robust, tapering-upper mandib]e curved, notched at tip-nostrils parily covered with feathers-head flatiened above-neck short-wings rather long-tail moderate, slightly emarginate-tarsi longer than the middle toesinner toe shorter than the outer; claws much compressed, arched, acute.]

\section{PYRANGA RUBRA-LINN.}

\section{SCARLET TANAGER.}

Scarlet Tanager, Tanagra rubra, Wils. Amer. Orn.

Tanagra rubra, Bonap. Syn.

Scarlet Tanager, or Black-winged Summer Red Bird, Sw. \& Rich,

Scarlet Tanager, Tanagra rubra, Nutt. Man.

Scarlet Tanager, Tanagra rubra, Aud. Orn. Biog.

Specific Character-Adult male with the plumage bright scarlet, except the wings and tail feathers, which are black. Female with the upper parts green, tinged with yellow; lower parts dull yellow, tinged with green; wings and tail feathers brownish-blackLength six inches and a half, wing three and five-eighths.

In winter, the male appears in the livery of the female.

This splendid species is better known to many persons by the name of "Fire Bird," or "Black-winged Red Bird."

Early in the month of May, the Scarlet Tanager arrives from its winter residence, which is said to be in Tropical America ; its migration extends to the northern limits of the Union. Its choice of residence is the high, dry, timber lands. Although retiring in its 
habits, it occasionally visits the cultivated grounds, sometimes building its nest in the fruit trees. The eggs, three in number, are dull blue, spotted with brown.

This species is the only one of the Genus that is found in this vicinity. It has nothing to recommend itself particularly to our notice other than its beautiful plumage. Its song consists merely of a few monotonous notes.

Like the Purple Finch and Red-breasted Grosbeak, at times it displays powers of ventriloquism.

Although distributed all over the Island, it is not very abundant; and I have noticed it for several successive years to be most plentiful in the woods at Raynor South. It is by no means an active bird, and seems to be partial to certain localities, beyond the limits of which it reluctantly passes, even when pursued. It is usually observed on the middle branches of the forest trees, from which it darts after butterflies and other winged insects, and sometimes descends to the ground in pursuit of coleopterous insects. 


\title{
F A M I L Y A G E L A I N $\mathrm{E}$
}

\author{
MARSH BLACKBIRDS.
}

\section{GENUS DOLICHONYX-SWAINSON.}

\author{
RICE BIRD.
}

[Bill short, thick, robust, conical; neck short; body rather full; wings rather long, pointed; tail of moderate length; the feathers rather narrow and pointed ; tarsi longer than the middle toes; toes rather large ; claws very long, slender, point acute.]

\section{DOLICHONYX ORYZIVORA-LINN.}

\section{RICE BIRD}

Rice Bunting, Emberiza oryzivora, Wils. Amer. Orn.

Icterus agripennis, Bonap. Syn.

Dolychonyx oryzivorus, Sharp-tailed Rice Bird, Sw. \& Rich.

Rice Bird, or Bob-o-link, Nutt. Man.

Rice Bird, Icterus agripennis, Aud. Orn. Biog.

Specific Character-Bill stout, conical; tarsi shorter than the middle toes; tail feathers pointed, becoming abruptly narrow toward their ends. Adult male, in summer; with the head, fore neck, and sides of the neck, lower parts, tail feathers, and wings, black; a broad band of brownish-yellow on the hind neck; fore part of the back black, the feathers edged with yellowish, as are the secondaries and their coverts - rest part of the back light gray, changing to white on the rump; scapulars white. Female with 
the upper parts light yellowish-brown, streaked with blackishbrown; lower parts light grayish-yellow, deeper on the breast; the sides marked with dusky. Length seven inches, wing three and three quarters.

In the State of New York, this bird is familiarly known by the name of "Bob-o-link ;" in Pennsylvania it is called "Reed Bird;" and at the South, "Rice Bird."

In the latter part of the month of May the Rice Bird arrives among us from the South, and continues with us during the summer. Associated in large flocks, it resorts to the fields and meadows. Its food consists of various insects and seeds, on which it becomes very fat, and is considered a delicacy.

The nest is placed upon the ground, and formed of dry leaves and coarse grass; the eggs, four in number, are bluish-white, irregularly spotted with blackish-brown. It is frequently taken in trap cages, and exposed for sale in the market. It soon becomes reconciled to confinement, and delivers a variety of pleasing notes ; but with the loss of liberty, its voice loses much of its clearness, and does not compare with the sweet notes it is heard to chant when: hovering in the air.

The change of plumage, from spring to fall, to which the male is subject, has been a matter of much controversy. In the fall, the males assume the dress of the females, which has induced many persons to suppose that all those which returned to them in the fall were females. 


\title{
GENUS MOLOTHRUS-SWAINSON.
}

\author{
COW BIRD.
}

[Bill very short, thick, conic, Finch-like, compressed-culmen very slightly arched; wings pointed, the first three quills longest ; tail nearly cven.]

\section{MOLOTHRUS PECORIS-GMEL.}

\section{COW-PEN BIRD.}

Cow Bunting, Emberiza pecoris, Wils. Amer. Orn.

Icterus pecoris, Bonap. Syn.

Molothrus pecoris, Cow-pen or Cuckoo Bunt, Sw. \& Rich.

Cow Troopial or Cow Blackbird, Icterus pecoris, Nutt. Man.

Cow-pen Bird, Icterus pecoris, Aud. Orn. Biog.

Specific Character-The head and neck dull brown; rest parts black, glossed with green. Female grayish-brown, lighter beneath.

To those persons who are accustomed to observing the habits and manners of birds, the extraordinary conduct of the Cow Bunting appears very remarkable. With all other species with which we are familiar, the business of building their nests and rearing their young, seems to us to be the most happy period in their lives. Often have we witnessed how cheerfully these native architects labor while preparing a suitable dwelling in which to cradle their offspring, and how carefully it is guarded and boldly defended, from before the bursting of the eggs, until their well-tutored progeny have acquired sufficient vigor to mingle with the countless numbers that embellish creation. Why, then, is it that Nature, in the subject of our remarks, presents an anomaly as singular as it is unaccountable? 
The Cow-pen Bird, like the European Cuckoo, destitute of all those attachments for which the rest of the feathered race are so remarkable, never builds a nest, or sits upon its eggs, which are promiscuously dropped in the nests of other species-thus leaving the perpetuity of their race to chance, and imposing upon those of neither kith nor kin, the arduous task of incubation.

Wilson states that the eggs of these birds are hatched in two days less than those in whose nesis they are deposited. Thus we see that Nature provides for the continuance of the race. Were it two days later, instead of two days earlier, this species would become extinct. As soon as the young foundling appears, the female leaves the nest to provide for its support, and bestows upon it every attention; until no longer requiring this motherly care, it quits the place of its birth, and joins the roving band of polygamists. By many, this extraordinary trait of character is attributed to a wanton recklessness in regard to their progeny. Althoughas writers have stated-there is nothing to be observed in the formation of this bird, to render it incapable of incubation; yet we must believe it to be the effect of some secret cause, which has thus far escaped the observation of the most profound naturalists.

The Cow Bird, so called from its habits of frequenting the pasture fields, and following the cattle, for the purpose of procuring insects which they disturb, arrives among us from the South, where it passes the winter, in the early part of April. When migrating northward, many pass on to the Fur countries, and return in the latter part of September, then collecting in large flocksand at this period, in company with the Red-winged Starlings, pay pccasional visits to the corn-fields. 


\title{
GENUS AGELAIUS-SWAINSON.
}

\author{
MARSH BLACKBIRD.
}

[Bill shorter than the head, robust, conical, straight-ridge of the bill flattened toward the lase; tip of upper mandible depressed; head ovate, of moderate size ; neck short ; hody rather full; wings of moderate length ; tall rather long, rourided; tarsi longer than the middle toes; claws long, slender, arched-hind toe and claw strongest.]

\section{AGELAIUS PHCENICEUS-LINN.}

\section{RED.WINGED STARLING, OR MARSH BLACKBIRD.}

Red-winged Starling, Sturmus prœdatiorius, Wils. Amer. Orn. Icterus phœniceus, Bonap. Syn.

Agelaius phœniceus, Red-winged Maize Bird, Sw. \& Rich.

Red-winged Black Bird, Icterus phœniceus, Nutt. Man.

Red-winged Starling, or Marsh Blackbird, Aud. Orn. Biog.

Specific Character-Adult male with the plumage glossy-black, excepting the smaller wing coverts, the first row of which are cream color-the rest scarlet. The female is nearly two inches less; the upper parts black, the feathers margined with pale brown; lower parts streaked with black and dull white; a band of pale brown over the eye, and some of the smaller wing coverts slightly tinged with red. Length of male nine inches, wing four and three quarters.

"The Red-winged Blackbird is said to inhabit during the summer months the whole of North America, from Nova Scotia to Mexico, and is found in the interior from the 53d degree across the whole continent, to the shores of the Pacific, and along the coast as far as California." -Nutall.

It arrives on Long Island about the first of April; generally preferring low situations, it is found in all our swamps and mead. 
ows. At this season it subsists on various kinds of insects; as the season advances, the young and tender ears of corn, which it has protected from the ravages of the grub-worm, contributes wholly to its support. Early in May it commences building its nest, which is usually placed on an alder-bush, in some swamp or marsh, and sometimes it is found in a tussock of grass, on a wet meadow. The eggs, from three to five, are white, tinged with blue and faintly marked with purple. It alights on the ground, trees, and fences, and sometimes is seen climbing up the stalks of rank weeds, searching for insects. It is a very plentiful species-associates in large numbers-and when alighting, crowd so close together, that with the gun great havoc is made. Its flight is usually even. When on the wing, its sombre plumage is pleasingly relieved by the brilliant scarlet markings on the wings of the males, which at all times render them conspicuous.

\section{GENUS ICTERUS-BRISS.}

\section{ORIOLE.}

[Bill rather shorter than the head, a little decurved, conical - tapering to a sharp point ; head moderate; neck rather short; body rather slender; wings of moderate length; tail slightly emarginate; tarsi rather longer than the middle toes ; toes moderate-hind toe strongest.]

\section{ICTERUS BALTIMORE-LINN.}

\section{BALTIMORE HANG-NEST, OR ORIOLE.}

Baltimore Oriole, Oriolus Baltimore, Wils. Amer. Orn. Icterus Baltimore, Bonap. Syn.

Baltimore Oriole, or Golden Robin, Icterus Baltimore, Nutt. Man.

Baltimore Oriole, Icterus Baltimore, Aud. Orn. Biog.

Specific Character-Adult male with the head neck all round, fore part of the back, wings, and tail feathers black; outer web of secondary coverts broadly margined with white-wing quills margined externally with the same; tail feathers black, toward their ends yellow, which color occupies a large portion of the outer feath- 
ers ; rest parts reddish-orange, deeper on the breast. Female with the head, neck, and fore part of the back brownish-black, intermixed with dull yellow; hind part of the back light brownish-yellow, brighter on the rump; lower parts duller than the male, and about half an inch less in length. Length of male, seven inches, wing three and seven-eighths.

The "Golden Robin," as it is more familiarly termed, is not very abundant on Long Island. It seems to prefer higher grounds, distant from the sea. In other portions of this State it is quite common. In Rockland county, my friend Mr. Bell, informs me that he has killed as many as twenty-five in the course of two hours, which is a greater number than you would be likely to meet with during a weeks's ramble over any part of Long Island. A few, however, breed there-and from the singular manner in which it constructs its nest, which is suspended from the limb of a tree, it is known by the name of "Hang-nest." The eggs, whigh are five in number; are white, faintly dotted and tinged at the large end with purple. According to Wilson, the Baltimore Oriole inhabits North America from Canada to Mexico, and is found as far South as Brazil. During the period of re-production it prefers the cultivated grounds, but as soon as the young are able to protect themselves, they pipe their clear and mellow whistle from the tops of the tallest forest trees. 


\section{ICTERUS SPURIUS-GMEL.}

\section{ORCHARD HANG-NEST, OR ORIOLE.}

Orchard Oriole, Oriolus mutatus, Wils. Amer. Orn.

Icterus spurius, Bonap. Syn.

Spurious or Orchard Oriole, Icterus spurius. Nutt. Man.

Orchard Oriole, Icterus spurius, Aud. Orn. Biog.

Specific Character-Bill along the gap eleven-sixteenths of an inch ; tarsi thirteen-sixteenths; tail much rounded, without spots; the outer feathers tipped with dull white. Adult male with the head and neck all round, fore part of the back and tail feathers, black; wings brownish-black, margined with dull white, secondary coverts and tail feathers tipped with the same; rest parts, including the lesser wing coverts, chestnut-red. Female with the upper parts dull yellowish-green ; lower parts pale yellow ; secondary and lesser wing coverts tipped with white. Young male with the fore part of the head, throat, and fore neck, black; breast, abdomen, and sides of the body, greenish-yellow, marked with reddish-brown; upper parts yellowish-green; hind part of back, rump, and upper tail coverts, marked with dull red; wings and tail brownish-black; secondary and first row of small coverts broadly tipped with white. Length of adult six inches and a half, wing three and one-eighth.

This species, more abundant than the Baltimore, is found in all our orchards. As if aware of the valuable service it renders to the husbandman in removing numberless insects that infest the fruit-trees during spring and summer, it becomes quite familiarand, like the former, willing to confide in man, suspends its nest near the cottage-door. The Orchard Oriole arrives among us in the latter part of May, and like the Baltimore, the males are in ad. vance of the females several days. In the month of September it migrates southward. 


\section{GENUS Q UISCALUS-VIEILL}

\section{CROW BLACKBIRD.}

[Bill as long as the head, compressed from the base, strong, tapering-upper mandible toward the end curving over the lower; nostrils half closed by a membrane; head of moderate size ; neck rather short, full; wings moderate; tarl long, rounded, slightly concave; tarsi as long as the middle toes; feet moderate; toes rather long, hind toc strongest; middle toe longest, and Lnited to the outer at the base by a membrane; inner free.]

\section{QUISCALUS VERSICOLOR-VIEILL.}

\section{PURPLE GRAKLE.}

Purple Grakle, Gracula quiscala, Wils. Amer. Orn.

Purple Grakle, Gracula quiscala, Bunap. Amer. Orn.

Gracula quiscala, Bonap. Syn.

Comınon Crow Blackburd, Quiscalus versicolor, Nutt. Man Quiccalus versiculur, Cumnon Purple Boat-tail, Sw. \& Rich. Purple Grakle, or Common Crow Blackbird, Quiscalus versicolor, Aud.

Specific Character-Bill rather long, stout; tail very long, graduated, concave. Adult male, when seen in the air or on the ground, the general plumage seems to be black; but when closely examin$\mathrm{cd}$, the head, neck all round, and fore part of the breast, exhibits glossy steel blue and green reflections. The rest of the lower parts and the back have a bright coppery appearance; the secondaries and their coverts glossed with violet; the primaries and tail feathers are black, glossed with blue and purple; tail long, and much rounded. Female smaller than the male; the plumage dull brown, lighter beneath, with a few green reflections. Length of male twelve inches, wing five and three quarters.

About the first of April the Common Crow Blackbird visits Long Island from the South, and continues to arrive in scattered flocks until its loud chattering is heard in all our swamps and meadows. This common species is found in all parts of the United States, and is said to inhabit all parts of the continent. Late in autumn, it migrates southward. Wilson informs us, that "a singular attachment frequently takes place between this bird and the Fish Hawk. 
The nest of the latter is of very large dimensions-often from three to four feet in breadth, and from four to five feet high, composed externally of large sticks or faggots, among the interstices of which sometimes three or four pairs of Crow Blackbirds will construct their nests, while the Hawk is sitting or hatching above them.Here each pursues the duties of incubation and of rearing its young, living in the greatest harmony, and mutually watching and protecting each other's property from depredators."

\section{QUISCALUS FERRUGINEUS-LATH.}

\section{RUSTY GRAKLE.}

Rusty Grakle, Gracula ferruginea, Wils. Amer. Orn.

Quiscalus ferrugineus, Bonap. Syn.

Scolecophagus ferrugineus, Rusty Maggot.eater, Sw. \& Rich.

Rusty Blarkbird, Quiscalis ferrugineus, Nutt Man.

Rusty Grakle, Quiscalis ferrugineus, Aud. Orn. Biog.

Specific Character-Tail rounded; fore part of the back transversely marked with reddish-brown. Adult male with the plumage glossy black, with green reflections; the feathers, particularly those on the fore part of the back, are tipped with reddish-brown ; tail feathers rather broad, and slightly rounded. Female rather smaller than the male, with the plumage duller. Length of male nine inches, wing four and three quarters.

This species, not so abundant as the former, visits us in spring, and in the early part of A pril, retires to the more northern latitudes to breed. According to Dr. Richardson, it arrives on the Saskatchewan in the latter part of April, and at Great Bear Lake, lat. 65 deg., by the third of May, generally in pairs, which for a time frequent the sandy beaches of secluded lakes, and feed on coleopterous insects. It returns to us in the latter part of September, then frequenting the corn-fields, which furnish the principal part of its food. At the approach of winter, it takes its departure for the South. 


\title{
F A M I L Y S T U R N I N ÆE.
}

\author{
STARLINGS.
}

GENUS STURNELLA-VIEILL.

MEADOW STARLING.

[Bill rather long, tapering ; upper mandible rounded above; nostrils largearched, with a naked membrane; head and neck moderate ; body rather longwings rather broad, of moderate length ; tail of moderate length, of twelve acute feathers.]

\section{STURNELLA LUDOVICIANA-LINN.}

\section{CRESCENT MEADOW STARLING.}

Meadow Lark, Alauda magna, Wils. Amer. Orn.

Sturnus ludovicianus, Bonap. Syn.

Sturnus ludovicianus, Crescent Starelet, Sw. \& Rich.

American Stariing, or Meadow Lark, Nutt. Man.

Meadow Lark, or American Starling, Aud. Orn. Biog.

Specific Character-On the fore neck a large crescent of black. Adult with a yellow line from the nostril to the eye; throat, breast, and abdomen, rich yellow, with a large crescent of black on the fore neck; sides of the body and lower tail coverts reddishwhite, streaked with black; upper parts dark brown, the feathers bordered with dull yellow; a central band on the upper part of the head, and a band on the side of the head, passing over the eye, of 
the same color; a line behind the eye black; wings dark brown, the outer webs of the secondaries lighter, and barred with black; outer three tail feathers white, with a longish spot of black on the outer web near the end ; fourth feather with a large portion of the inner web brown; the rest dark brown, their edges lighter. Length ten inches and a half, wing four and three quarters.

With us, this common bird is a constant resident. The pasture fields and meadows are its favorite resort, and furnish an abundant supply of seeds and insects, which constitute its food. It has little to recommend it to our notice, excepting its rich plumage. Its song consists of a few rather melancholy notes. Its flesh, though esteemed by many, is generally tough, unless when young-and then it has nothing of a game flavor. It sometimes perches on trees, usually selecting the higher branches; it procures its food on the ground, and prefers to build its nest there - and often chooses a tuff of grass for that purpose, where it lays four or five white eggs, marked with reddish-brown.

The Meadow Lark is distributed throughout the United States, and it is said to range over the whole of the continent. 


\title{
F A M I L Y C O R V I N E.
}

\author{
CROWS.
}

\section{GENUS CORVUS-LINN.}

\section{CROW.}

[Bill rather long, stout-nostrils covered with stiff featbers; head large; neck rather short; body robust; wings long ; tail rounded, of moderate length ; tarsi and toes stout.]

\section{CORVAX CORAX-LINN.}

\section{RAVEN.}

\author{
Raven, Corvus corax, Wils. Amer. Orn. \\ Corvus corax, Bonap. Syn. \\ Corvus corax, Raven, Sw. \& Rich. \\ Raven, Corvus coraz, Nutt. Man. \\ Raven, Corvus coras, Aud. Orn. Biog.
}

Specific Character-Bill exceedingly stout, along the gap three inches; nostrils covered by long stiff feathers; length of tarsi two inches and three eighths; the feathers on the fore neck elongated and pointed. Adult with the plumage deep black, glossed with purple and steel blue; bill and feet black; tail rounded. Length twenty-six inches, wing sixteen.

It is said that the Raven is a denizen of almost every part of the globe. In the United States it is common, though more abundant 
in the interior-and it has been traced westward to the shores of the Pacific. It was found breeding on the rocky shores of Labrador by Mr. Audubon, and according to Dr. Richardson, visits the remotest islands of the Polar Seas. In the middle Atlantic districts it is not abundant. A few occur on the sea coast of New Jersey, and occasionally it is observed soaring in wide circles over the shores of Long Island. On the large lakes it is abundant, where it is attracted by the number of dead fish cast on shore by the waves.

The Raven is omnivorous, though its choice of food seems to be dead animal matter-and it does not reject the most putrid animal substances. It also attacks small living quadrupeds, and not unfrequently descends upon the poultry, and is charged with killing lambs, and even full-grown sheep; and it is said to follow the hunters, and feed on the offal of their game. Its hoarse croaking and melancholy aspect, added to the rest of its evil qualities, have brought it sadly into disrepute. By some, it is denounced as a robber, and shot whenever opportunity offers; by others, more superstitious, it is dreaded as a bird of ill omen. 


\title{
CORVUS AMERICANUS-AUDUBON.
}

\author{
AMERICAN CROW.
}

Crow, Corvus corone, Wils. Amer. Orn.

Corvus corone. Bonap. Syn.

Corvus corone, Crow, Sw. \& Rich.

Crow, Corvus corone, Nutt. Man.

American Crow, Corvus Americanus, Aud. Orn. Biog.

Specific Character-Bill along the gap two inches and oneeighth, tarsi two and a quarter ; bill not so strong as the preceding and not so fully feathered at the base; general color of plumage black, with purplish-blue reflections; bill strong, black, as is the color of the legs. Length eighteen inches, wing thirteen.

In our large list of North American Birds, no species is better known than this audacious pilferer of corn-fields. In all the agricultural districts, it is proverbial for its attachment to Indian corn, which it destroys and carries off in such quantities, as to prompt the farmer to many ingenious devices for the protection of his crop. Of all the stratagems resorted to, none seem to be more effectual than that of stretching a line around the field. So fearful are they of being ensnared, that this scare-crow conveys to them an idea of greater danger than any other which $\mathrm{I}$ have ever known to be adopted.

With the gun, but little can be accomplished; so suspicious are they of the near approach of man, that before the gunner arrives within firing distance, the alarm is given, and all fly off to a safe retreat, and wait a favorable opportunity for again descending upon the field, and recommencing their repast. 
Having nothing to recommend it in plumage, unfit for food, and being a notorious pest, this much despised and abundant species would have long since become extinct, were it not for its vigilance and sagacity, which it possesses in a degree unsurpassed by any of the feathered tribe. Its thieving propensities are not only directed against the husbandman, but it delights in robbing the nests of other birds of their eggs, for which it is attacked by the injured party, until compelled to abandon its piratical design. Among its assailants, none are more formidable than the renowned King-bird, from whose fury and courage it seldom escapes withou $\mathfrak{t}_{\mathfrak{t}}$ paying dearly for its intrusive visits.

The only redeeming trait of character which we can relate in the history of this mischievous and noisy bird, is the remoring of thousands of destructive insects previous to the season of planting. Yet branded an outlaw, it roams about, receiving favor from none, and despised by all.

In the month of April, and sometimes in the latter part of March, the Crow commences building its nest. For this purpose it retires to the woods. The nest, which is formed of a variety of materials, such as sticks, hair, wool, and moss, is usually placed among the higher branches of the tallest trees; the eggs, which are four, and sometimes five in number, are of a brown color, tinged with green, and marked with small spots and blotches of blackish-brown. During the time of hatching, the male is very attentive to his mateand occasionally shares with her the task of incubation. From the time it commences preparing its nest until the young are able to fly, its loud and coarse cry is seldom heard-no doubt adopting this silent manner that its nest may escape observation.

With us, this species is only partially migratory; many remain during winter. At that season, when food is difficult to be procured, it becomes less shy, and is readily killed by baiting it with the carcasses of dead horses or other quadrupeds. Though noted for its shy, suspicious, and unsociable disposition, still, when taken young, it is easily raised and domesticated. 


\title{
GENUS GARRULUS-BRISS
}

\author{
JAY.
}

[Bill of moderate length, straight, tapering, strung, slightly notched-nostrils covered with feathers; head large-neck short-body stout-_wings rather short -tail lung, much rounded-tarsi compressed-feet and toes rather stout, outer toe longer than the irner.]

\section{GARRULUS CRISTA'TUS-LINN.}

\section{BLUE JAY.}

\author{
Blue Jay, Corvus cristatus, Wils. Amer. Orn. \\ Garrulus cristatus, Blue Jay, Sw. \& Rich. \\ Blue Jay, Corvus cristatus, Nutt. Man. \\ Blue Jay, Corvus cristatus, Aud. Orn. Biog.
}

Specific Character-Lores, a narrow band on the forehead and a broad band on the neck black. Adult with the upper parts light purplish-blue-the crest of the same color; a band on the forehead, lore, a line behind the eye, and a band around the neck, black; wings and tail ultramarine blue; secondaries, their coverts, and tail feathers barred with black and broadly tipped with white, excepting the middle pair, which are but slightly tipped with the same; cheeks and throat bluish-white; fore neck and breast grayish-white ; abdomen and lower tail coverts white; tail long and rounded. Lengtlı twelve inches, wing five and a quarter.

On Long Island this handsome and well known bird is met with throughout the year. In its habits it is rather solitary, seldom associating in any considerable number except in spring, at which season it collects in large flocks and passes on northward, continuing 
it migrations to the fur countries, where the majority spend the breeding season; though in diminished numbers we find its during summer distributed throughout our woods. Its favorite food is grain and fruit; it also eats insects of various kinds, and in autumn, the produce of the oak and chestnut trees constitute its chief support.

The notes of the Blue Jay are various-at intervals mimicking the cry of the Hawk, or the dull coarse voice of the crow, and at tîmes introducing low and somewhat musical notes, in imitation of some of our celebrated songsters. It is quite watchful, and considerable address is required to approach it. When its safety depends on retreat, it utters a harsh scream, and retires to a distant tree; it usually alights on the middle branches, and perches from limb to limb until it arrives at the top, in which situation its bright plumage renders it conspicuous. In winter, when the ground is corered with snow, it becomes more familiar, visits the out-buildings -and when opportunity offers, enters the barn, and feeds on the threshed grain-and with boldness incited by hunger, draws near the farmer's dwelling, for which piece of temerity it often forfeits its life; and when food is thus difficult to be obtained, it will, like the Crow, rather than suffer with hunger, feed on carrion. The nest of the Blue Jay is formed of twigs and other coarse materials, lined with fibrous roots; it is usually placed on the upper part of a tree - it is found in the pines, oaks, and sometimes in the retired part of an orchard. The eggs, which are from four to five, are dull olive, spotted with brown. During the season of incubation, the male, on his visits to the nest, observes strict silence, but at all other times is noted for his noisy and frequent outcry. 
F A M I L Y L A N I R Æ.

SHRIKES.

GENUS LANIUS-LINN.

SHRIKE.

[Bill of moderate length, robust, compressed, upper mandible rounded above, hooked at tip; head large, upper part broad; neck short ; body full; tail long, much rounded. Tarsi rather short; feet stout, toes rather small, hind toe strong ; claws large, arched, and sharp.]

\section{LANIUS BOREALIS-VIEILL,}

\section{GRE.AT AMERICAN SHRIKE.}

Great American Shrike ur Butcher Bird, Lanius excubitor, Wils. Amer. Orn. Lanus septentrionalis, Bonap. Syn.

Lanius borealis, Great Norhern Shrike, Sw. \& Rich.

Great Ainerican Sizike, Nutt. Man.

Great Anerican Shrike, Lumus excubitor, Aud. Orn. Biog.

Specific Characler-Loral space, a patch behind the eye, wings and tail brownish-black; basal half of the primaries, the larger portion of the lateral tail eathers, the next three toward their ends and the tips of the rest white. Adult male with the upper parts ash-gray, tinged with pale blue; loral space and a patch behind the eye black; a white streak over the eye; lower parts grayish white, faintly marked with transverse undulating lines of dusky; wings brownish-black; primaries at base white-the secondaries and their coverts tipped with the same; tail long and rounded, black-the middle feathers tipped with white, which color increases on the rest, the larger portion of the lateral feathers being of that 
color. Female with the head and hind neck tinged with brown, and the lower parts more distinctly banded. Length ten inches, wing four and three quarters.

Juring the winter months the Great American Shrike is not uncommon in the middle districts. Early in the spring, the majority retire northward, where they pass the season of re-production. Dr. Richardson informs us that it is most frequent on the banks of the Saskatchewan. The nest, which is formed of dry grass and lichens, and lined with feathers, is built in the fork of a tree; the eggs, five or six in number, are of a pale bluish-gray, spotted at the large end irregularly with dark yellowish-brown. It is a very shy and suspicious bird, and when not pursuing its prey, is usually perched on the summit of a tall tree. From its lofiy situation, it can detect the gunner before he has arrived within gunshot. As if aware of his evil intentions, it utters a loud scream, and flies to a neighboring tree. After repeating this manœurre several times, it becomes less timid, and allows the gunner to approach too near to avoid his fatal aim. It feeds on insects, grasshoppers being its favorite food; but when hard pressed, will attack small birds, both of which it is said to impale on thorns-and from this act of cruelty it has received the appellation of "Butcher Bird." 


\title{
F A M I L Y VI R E O N I N
}

\section{GREENLETS.}

\section{GENUS VIREO-VIEILL.}

\author{
GREENI.ET.
}

[Bill rather short, compressed toward the end, rather strorg. with bristles at the base-upper mandible curred at tip, notched-lower shorter, recurved at tip ; head rather large, neck short, wings rather long-tail of moderate length ; tarsi slender; iniddle toe longest, inner toe shorter than the outer, hind toe strungest.]

\section{VIREO OLIVACEUS-LINN.}

\section{RED-EYED GREENLET.}

Red-eyed Flycatcher, Muscicapa olivacea, Wils. Amer. Orn.

Vireo olivaceus, Bonap. Syn.

Vireo olivaceus, Red-eyed Greenlet, Sw. \& Rich.

Red.eyed Vareo, Vireo olivaceus, Aud. Orn. Biug.

Specific Character-Irides red. Adult with the upper part of the head bluish, bordered with dusky; a band of dull white from the nostrils over the eyes which are red, directly below a band of dusky; upper plumage olivaceus; wings and tail plain brown, edged with greenish ; lower parts grayish-white; sides of the body tinged with green. Longth five inches and a half, wing three and a quarter.

The harsh and loud note of this numerous species is heard in all our woods and orchards, as well as in the pleasure-gronnds of our cities; indeed it is almost impossible to ramble over any part of the Island during summer without hearing the never-ceasing notes of the Red-eyed Vireo. It arrives in May, and in the latter part of the month builds its nest. The eggs, five in number, are white, finely dotted with brownish-black. 


\title{
VIREO NOVEBORACENSIS-GMEL.
}

\author{
WHITE-EYED GREENLET.
}

White-eyed Flycatcher, Muscicapa cantatrix, Wils. Amer. Orn.

Vireo novahorencis, Bonap. Syn.

White-eyed Vireo or Flycatcher, Vireo noveboracensis, Nutt. Man.

White-eyed Flycatcher or Vireo, Vireo noveboracensis, Aud. Orn. Biog.

Specific Character-Irides white. Adult with a band of yellow at the base of the upper mandible; eyelids of the same color; upper parts greenish-olive; hind neck deep gray; wings and tail brown, edged with greenish; two bands on the wings formed by the tips of the secondary coverts and first row of lesser wing coverts, which are pale yellowish-white; lower parts grayish-white; sides of the body light yellow; irides white. Length five inches, wing two and a half.

The White-eyed Flycatcher is generally seen along the hedges or in low thickets It is not a very sprightly bird, but sings with a good deal of spirit, seeming to delight in giving utterance to its varied notes. It builds its nest among the briars, in which are deposited five white eggs, spotted with black.

The birds of this Genus are readily distinguished from the Flycatchers by their bills, which are much stronger, and less depressed at the base. They feed chiefly on winged insects, and their manners and customs are also similar to the Flycatchers. 


\section{VIREO FLAVIFRONS_VIEILL.}

\section{YELLOW-THROATED GREENLET.}

Yellow-throated Flycatcher. Muscicapa sylvicola, Wils. Amer. Orn.

Vireo Aavifrous, Bonap. Syn.

Yellow-throated Vireo, Nutt. Man.

Yellow-throatcd Flycaiclicr, or Vıreo, Vireo flavifrons, Aud. Orn. Biog.

Specific Character-Bill along the gap eleven-sixteenths of an inch; a band from the nostril to the eye dull yellow; a line over the eye brighter; throat, fore neck, and breast yellow. Adult with a yellow band commencing at the base of the upper mandible, and passing over the eye; a dusky spot before the eye; upper parts greenish-olive, with the rump, upper tail coverts, scapulars, and lesser wing coverts bluish-gray: wings and tail dusky brown; two distinct bands on the wings; outer vane of the lateral tail feathers white; throat, fore neck, and upper part of the breast, yellow; sides of the neck and sides of the breast same as the upper parts; rest of the lower plumage white. Length five inches and three quarters, wing three.

This species passes its time in the woods. It is generally observed among the middle or upper branches, and like the rest of the Vireos, is destitute of the sprightly, graceful manner displayed by the Sylvias and many of our Flycatchers. With us, the Yellow-throat is tolerably common, but not so plentiful as the Whiteeyed Vireo. It remains on Long Island throughout the summer. The nest, which is built on a tree, contains usually four eggs, spotted with black on white ground. 


\title{
VIREO SOLITARIUS_VIEILL
}

\author{
SOLITARY GREENLET.
}

\begin{abstract}
Solitary Flycatcher, Muscicapa solitaria, Wils. Amer. Orn. Vireo solitarius, Bonap. Syn.

Solitary Vireo, or Flycatcher, Vireo solitarius, Nutt. Man.

Solitary Flycatcher, or Vireo, Vıreo solitarius, Aud. Orn. Biog.
\end{abstract}

Specific Character-A band from the nostril to the eye, and a broad ring round the eye white. Adult with a broad band of white at the base of the upper mandible, passing back to the eye, which is surrounded by the same color; a dusky spot before the eye ; head bluish; back, rump, and upper tail coverts olivaceous; wings and tail brownish-black, the outer webs of the feathers margined with olivaceous, the inner secondaries rather broadly margined with dull white, of which color are the tips of the secondary coveris and first row of small coverts; the outer web of the lateral tail feathers, the inner webs of all edged with the same; throat, fore neck, and middle portion of the breast and abdomen white; sides of the body greenish-yellow. Length five inches and a half, wing two and seven-eighths.

On Long Island, as elsewhere in the vicinity of New York, this species is not common. The few that $I$ have met with have been found in similar situations with those inhabited by the Yellow. throated Vireo, to which its manners and customs appear not unlike. It was first noticed by Wilson, he having met with but three specimens. According to Mr. Audubon, it inhabits, during the spring and summer months, the cane-brakes in Louisiana, and the alluvial lands near the Mississippi. He also found it abundant in Maine. Mr. Nuttall mentions having met with it in the early part of the month of May on the banks of the Columbia River. 


\title{
VIREO GILVUS-VIEILL
}

\section{WARBLING GREENLET.}

\author{
Warbling Flycatcher, Muscicapa melodia, Wils. Amer. Orn. \\ Vireo gilius, Bonap. Syn. \\ Warbling Vireo, Nutt. Man. \\ Warbling Flycaicher or Vireo, Vireo gilrus, Aud. Orn. Biog.
}

Specific Character-A band over the eye and loral srace dull white; wings without bands. Adult with the upper yarts light brown, tinged with greenish; wings and tail plain brown, the outer webs edged with the same tinge as on the back; a band of dull white from the base of the lower mandible over the eye, extending beyond the eye ; sides of the head and neck grayish-brown; throat fore neck, breast and abdomen dull white, faintly tinged with yellow; sides of the body tinged with greenish-yellow. Length five inches and a quarter, wing two and three quarters.

On Long Island the musical notes of this sweet songster are but seldom heard, nor have I any where found this species plentiful.It is partial to the cultivated grounds and has been observed on the trees that adorn the city. Its manners are more sprightly than any of its Genus, and its voice excels our finest-toned Sylvias. Its plumage has a resemblance to that of the Red-eyed Vireo. The color of the eyis, as well as its smaller dimensions, prevents it from being mistaken for that common species, and those who have listened to its minstrel lay, quickly detect it when it is roving about its favorite haunts. 


\title{
F A M I L Y P I P R I N $巴$.
}

\author{
MANAKINS. \\ ICTERIA VIRIDIS-GMEL.
}

\section{YELLOW-BREASTED CHAT.}

Yellow-breasted Chat, Pipra polyglotta, Wils. Amer. Orn.

Icteria viridis, Bonap. Syn.

Yellow.breasted Chat, Icteria viridis, Nutt. Man.

Yellow breasted Chat, Icteria viridis, Aud. Orn. Biog.

Specific Character-Adult with the bill and lores black; a white line from the nostril over the eye; a spot of white at the base of the lower mandible; upper parts deep olive green; fore neck and breast bright yellow; abdomen white. Length seven inches, wing three inches.

This-the only species of the genus met with-is during the summer quite common. It keeps along the fences among the close entangled briars, so that you frequently approach within a few feet of it at a monent when you are not aware that it is within the reach of your gun. It arrives in the middle of May, and soon commences building its nest, which is usually placed among the briars, a few feet from the ground. The eggs, four in number, are pale flesh color, spotted with brown. In its habits it is rather solitary. Its food consists of insects and berries, which it sometimes frequents the gardens to obtain. In the month of September it leaves for the South. 


\title{
F A M I L Y A M P E L I N E.
}

\section{CHATTERERS.}

\section{GENUS BOMBYCILLA-BRISS.}

\author{
WAXWING.
}

[Bill short, broad at the base, upper mandible declinate toward the tipnotched; head tufted, neck short, body full ; wings rather long-pointed; tail of moderate length - even; toes four-middle toe much the longest, connected at the base with the outer-inner free.]

\section{BOMBYCILLA CAROLINENSIS-BRISS.}

\section{CEDAR WAXWING.}

Cedar Bird, Ampelis Americana, Wils. Amer. Orn.

Bombycilla Carolinensis. Bonap. Syn.

Cedar Bird, or Cherry Bird, Nutt. Man.

Cedar Bird, Bombycilla Carolinensis, Aud. Orn. Biog.

Specific Character-Head crested; a band on the forehead, loral space, and a spot behind the eye, black. Adult with the head crested; a band from the nostril passing behind the eye; general color light grayish-brown; rump and upper tail coverts ash gray; abdomen pale ycllow; lower tail coverts white; wings and tail dusky, shaded with dull blue; secondaries tipped with wax-red; the tail featiers toward their ends yellow-in some specimens tipped with bright red waxen appendages, similar to those of the secondaries. Length six inches and a half, wing three and fiveeighths. 
The Cedar Bird inhabits North America from Canada to Mexi: co. Although the majority pass the winter in the Southern States, a few remain with us during the whole year. In the early part of March, large flocks are seen passing on to the middle districts. This species associates in such large companies, flying in such close, compact bodies, that many specimens are killed at a single shot; and those who are aware of the delicate flavor of its flesh, shoot large numbers for the table.

Notwithstanding this is one of our earliest birds in the spring, it is the last that builds its nest, deferring that event until the early part of June, at a period wherı most of our birds have raised a brood. The nest of the Cedar Bird is usually placed on the low branches of an apple tree. The eggs, four in number, are white, tinged with purple and spotted with black.

The food of this species consists chiefly of berries and other small fruits. When cherries ripen, it resorts to the trees in large flocks, and from its fondness for this fruit, it is called by many "Cherry Bird." Blackberries, strawberries, and whortleberries contribute largely to its subsistence; and when this delicious fare is no longer to be obtained, it feeds on dogwood, cedar, and winter berries.

Although destitute of song, it is admired for its beautiful soft and silken plumage. Its note is a single, feeble call, and even during the love season, when most of our upland birds express their happiness by displaying their vocal powers, the Cedar Bird zemains silent. 


\title{
BOMBYCILLA GARRULA-VIEILL.
}

\author{
BLACK-THROATED WAX.WING.
}

\author{
Bombycilla garrula, European chatterer, Sw. \& Rich. \\ Bumbycilla garrula, Bonap. syn. \\ Bombycilla gasrula, Bonap. Amer. Orn. \\ Erropean Waxın Chatterer, Nutt. Man. \\ Boheınian Chatterer, Bombycilla garrula, Aud. Orn. Biog.
}

Specific Character-Crest elongated; a large black patch on the throat; forepart of the head, sides of the throat and the under tail coverts chestnut-red. Adult with the plumage soft and silky; bill short, rather stout; neck short; body full; head crested; general color light grayish brown; rump, upper tail coverts, and abdomen, ash-gray; a black band commencing at the nostril, passing round the upper part of the head; throat and wings black; the outer webs of the primaries, excepting the first, tipped with yellow; the outer webs of the secondaries more largely tipped with white; primary coverts with the same; a bright red waxen appendage continuing from the shafts of the secondaries beyond their webs; tail black, shaded at the base with light gray, and tipped with yellow, the terminal portion of the shafts red, in some cases with red waxen appendages as on the secondaries; fore part of the head, sides of the throat and the upper tail coverts chestnut-red. Length nine inches, wing four and five-eighths.

Mr. Audubon states that the most southern locality in which he has known this species to have been produced, was in the neighborhood of Philadelphia. Several were shot on Long Island in 1830 and 1832. In the latter part of July, 1841, I was informed by Mr. Chrysler, who resides in Canada, in the immediate vicinity of the Falls of Niagara, that a few days before my arrival, he saw a bird in that neighborhood, differing from every other species that had ever come under his observation. He described it as resembling the Cedar Bird in general colors, though much larger, the crest longer, and a black patch on the throat, which corresponds with the description of the Bohemian Chatterer, which it doubtless was. In the United States it is unfrequent, and rarely observed except during 


\section{(166)}

winter. In the higher latitudes it has been observed in large num. bers, and it is said to possess much of the manners of the common Cedar Bird. It is stated in the Fauna Boreali Americana, or Northern Zoology, page 237, that "this elegant bird was detected in America in the spring of 1826, near the sources of the Athabasca, or Elk River, by Mr. Drummond, and by Dr. Richardson, the same season at the Great Bear Lake, in latitude 65 deg."

Dr. Richardson also makes a note of having observed a large flock, consisting of at least three or four hundred individuals, on the bank of the Saskatchewan, at Carleton House, early in May, 1827."They alighted in a grove of poplars, settling all on one or two trees, and making a loud twittering noise. They staid only about an hour in the morning, and were too shy to allow him to approach within gunshot."

\section{F A M I L Y S I T T I N}

\section{NUTHATCHES.}

\section{GENUS SITTA-LINN.}

\section{NUTHATCH.}

[Bill of moderate length-hard, straight, pointed; bristles at the base of the upper mandible; head ovate; leek short; body short, rather plump; wings moderate, first quill very small ; tail short, nearly even, of twelve broad feathers-feet robust-ioes long - tarsi rather short.]

\section{SITTA CAROLINENSIS-LINN.}

\section{WHITE BREASTED NUTHATCH.}

White-breasted Amcrican Nuthatch, Sitta Carolinensis, Wils. Amer. Orn.

Sitta Carolinensis, Bonap. Syr.

White-breasted American Nuthateh, Nutt. Man.

White-breasted Nuthatch, Sita Carolinensis, Aud. Orn. Biog.

Specific Character-Bill along the gap seven-eighths of an inch; the upper mandible straight, the lower rounded; upper part of the head, hind neck, and a band curving on the side of the neck black; 
sides of the head, sides and fore part of neck and the breast white. Young with the black on the head wanting. Adult with the upper part of the head and hind neck black; back and middle tail feathers grayish-blue; the rest of the tail feathers black, the tips of those next to the middle white; the rest witl a broad band of the same color toward the end; wings black, edged with light grayish blue; sides of the head and lower parts white; the sides of the abdomen and rent tinged with reddish-brown, which is the color of the inner webs of the under tail coverts. Length five inches and a half, wing three and a half.

This common bird is met with in all the woody districts of the United States, and is said to be distributed over the continent. It frequents the woods and wet lands, where it is seen moving round the body and larger branches of trees in search of insects and their larvæ. It is one of our most hardy birds, and remains with us throughout the year. It is an active climber, and when searching about the tree, is heard to utter at intervals a rather harsh note. In the early part of $A$ pril it commences building its nest, which is usually placed in a hollow tree. The eggs, five in number, are dull white, spotted with brown at the larger end. 


\title{
SITTA CANADENSIS-LINN.
}

\author{
RED-BELLIED NUTHATCH.
}

Red-bellied Nuthatch, Sitta Canadensis, Wils. Amer. Orn.

Sitta Canadensis, Bonap. Syn.

Red-bellied Nuthatch, Nutt. Man.

Red-bellied Nuthatch, Sitta Canadensis, Aud. Orn. Biog.

Specific Character-Upper part of the head black, bordered with white; a band from the nostril passing beyond the head, black; lower parts yellowish red. Adult with the upper part of the head, and a band from the nostril passing beyond the head, black, between which is a white band, which passes over the eye, continuing about the same distance as the black band behind the eye; throat and sides of the neck white; back grayish-blue; wings dark brown, edged with blue; middle tail feathers of the same color, the rest of the tail feathers are black, the outer two with a white band near their ends, the next two tipped with grayish-blue; lower parts deep yellowish-red. The female not so deeply marked on the head.Length four inches and a half, wing two and five-eighths.

This species, not so abundant as the preceding, is with us a winter visitant from the North, where it breeds. It arrives in the month of October and remains with us until April. The pine trees are its favorite resort, the seeds of which it is particularly fond of. It is frequently seen in company with the former species, from which it can readily be distinguished by its inferior size as well as by its notes, which are much sharper and delivered in a more hurried manner. 


\title{
F A M I L Y T R O C H I L I N E.
}

\section{HUMMING-BIRDS.}

\section{GENUS TROCHILUS-LINN}

\author{
HUMMING-BIRD.
}

[Bill long, straight, or slightly arched—body small—wings very long, acutetail rather long-feet short.]

\section{TROCHILUS COLUBRIS-LINN.}

\section{RUBY-THROATED HUMMING-BIRD.}

Humming-Bird, Trochilus colubris, Wils. Amer. Orn.

Trochilus colubris, Bonap. Syn.

Trochilus colubris, Northern Humming-Bird, Sw. \& Rich.

Ruby-throated Humning-Bird, Nutt. Man.

Ruby-throated Humming-Bırd, Trochilus colubris, Aud. Orn. Biog.

Specific Character-Male, upper parts green, with golden reflections; throat black, in certain lights ruby-red. Female, upper parts not so deep green, and the metallic lustre wanting on the throat. Adult male with the bill straight, very slender; upper parts and middle pair of tail feathers golden green; rest of the tail feathers dark brown, tinged with purple; upper part of the throat covered with deeply furrowed scale-like feathers, which, when placed in a certain light, produce a brilliant ruby-red color; sides of the body dusky, glossed with green; vent white; wings blackish-brown, glossed with violet, distinctly forked. Female without the brilliant feathers so conspicuous in the male; lower parts white; tail rounded, tipped with white. Young male, with the brilliant ornament on the throat not fully developed until the second year. Length of male three inches and a half, wing one and fiveeighths. Female larger than the male.

'This, the gem of our birds, is said to roam during spring and summer from 'Texas to the Fur countries, up to the fifty-seventh 
parallel. Three other species are found in North America-the Mango Humming Bird, which was procured by Mr. Audubon on the Florida Keys; the two others, T. anna and S. rufus, have been observed only on the western side of the continent-while in the tropical climates, a large number of species are known to exist.

Various speculations have been offered relative to the production of the brilliant and varied hues peculiar to the male-and being unable to explain why it slould possess such brilliant metallic lustre, I cannot do better than give the following remarlss on Humming Birds, by Sir William Jardine, Bart., contained in the Naturalist's Library, vol. 1, page 83.

"The structure of the feathers, which shine with so much lustre, has occupied the attention of most of their describers. Audibert has tried to demonstrate the cause on mathematical principles, the form of the feathers, and the manner in which the light strikes them; while Lesson is of opinion that the colors are due to elements contained in the blood, and diffused by circulation. He says, at the same time, that all the barbules and plumclets are deeply furrowed in the centre, and the light, when striking vertically, produces no color, or only black; but when striking transversely, every opposite side of the furrow acts as a reflector to the others, and in this way assists in producing the colors."

Bullock, when speaking of the same subject, says that "The preserved specimens were but the shadow in brilliancy to what they were in life."

The only opportunity which I have had of comparing preserved specimens with the living, is with the present species, and in all my comparisons, I observed but little or no difference. From this it would seem that the circulation had but little to do with it, and that we must trace it to some other cause than elements contained in the blood. These theories, however, are fanciful, and for want of a better, I am willing to adopt that part of Lesson's remarks which appears to me the most plausible - that it is attributable to the formation of the feathers, and the manner in which the light strikes them. 
"These beautiful and delicate beings have excited the admiration of their discoverers, and, indeed, of every one who has observed them. The ancient Mexicans used their feathers for superb mantles in the time of Montezuma, and the pictures so much extolled by Cortes, were embroidered with their skins. The Indian could appreciate their loveliness, delighting to adorn his bride with gems and jewelry plucked from the starry frontlets of these beauteous forms." - Naturalist s Library.

This well known species frequents the gardens, and delights to revel among the rich blossoms, preferring those that are tubular- such as the honeysuckle, larkspur, \&c.-from which it extracts its food. The honey of flowers is not its only means of subsistence; diminutive insects that lurk about the petals of flowers, and rarious species of sinall-ringed insects, also contribute to its support. The clover-fields are also a favorite resort, and it seems partial to a wild yellow tubular flower, which abounds in the swamps in the latter part of summer. Although it is the smallest and most delicate of all our birds, none are more quarrelsome. It seldom happens that two males meet without a violent battle ensuing, and it often attacks other birds which intrude upon its fragrant dominions.

Imaginative persons have suggested the idea that the humming sound produced by the wings when hovering over its favorite flower, has the effect of lulling to sleep its insect prey, that it may feed at leisure.

The Humming Bird arrives among us about the first of May, and in the latter part of the same month commences building its nest, which is usually placed against the branch of a tree, and constructed of pieces of various plants, interlined with fine materials. The eggs, which are two in number, are pure white. In the latter part of September it migrates southward. 


\section{F A M I L Y A L C E D I N E}

\section{KINGFISHERS.}

\section{GENUS ALCEDO-LINN.}

KINGFISHER.

[Bill long, straight, compressed--higher than broad at the base, tapering ; head large; neck short; wings long-tail of moderate length, even-tarsi exceedingly short-feet rather stout-loes four.]

\section{ALCEDO ALCYON-LINN.}

\section{BELTED KINGFISHER.}

Belted Kingfisher, Alcedo alcyon, Wils. Amer. Orn.

Alcedo alcyon, Bonap. Syn.

Alcedo alcyon, Belted Kingfisher, Sw. \& Rich.

Belted Kingfisher, Nutt. Man.

Belted Kingfisher, Alcedo alcyon, Aud. Orn. Biog.

Specific Character-Head crested; throat and neck all round, except a narrow space on the hind neck, white; the upper parts, and a broad band on the fore part of the breast, blue. Adult male with the upper parts and a bread belt across the fore part of the breast, blue; throat, sides of the neck, and a spot before the eye white-the lower parts of the breast of the same color; wings black; primaries barred with white-the inner webs, for half their length, same color; secondaries barred and tipped with white, the 
outer webs broadly margined with blue; tail feathers dusky, barred with white, and broadly edged with blue. "Female with the band crossing the upper part of the breast, tinged with reddish-brown; a band across the lower part of the breast, chestnut, of which color are the sides of the body. Length of male twelve inches and a half, wing six and a quarter.

This - the only species found in North America-is met with on all the streams in the United States, and it is said ranges over the whole continent. The Kingfisher is more common in the interior than on the sea coast; its favorite resort is the uncultivated banks of water courses, where, perched on a projecting limb, or mounted on a stump, it watches for finned prey. At other times it is seen passing rapilly over the surface of the water, or hovering over the timid fry, leisurely reconnoitering their movements. This well known and timid bird, when alarmed, utters a loud scream, and flies onward two or three hundred yards to another perch-thus keeping in advance of the gunner until he becomes tired of pursuit.

The nest of the Kingfisher is built in the high, dry bank of a water course, in which it digs out a hole to the depth of several feet. The eggs, five in number, are white and rounded. In au. tumn it migrates southward. 


\title{
F A M I L Y P I C I N
}

\section{WOODPECKERS.}

\section{GENUS PICUS-LINN.}

\section{WOODPECKER.}

[Bill strong, straight, tapering, of moderate length; wings moderate, first quill very short; tail of moderate length, or clongated, rounded; toes usually fuur, the hind toe short-in some species wanting. ]

\section{PICUS VILLOSUS-LINN.}

\section{HAIRY WOODPECKER.}

\author{
Hairy Woodpecier, Picus villosus, Wils. Amer. Orn. \\ Picus villosus, Bonap. Syn. \\ Hatry Woodpecker, Nutt. Man. \\ Harry Woudpecker, Picus villosus, Aud. Orm. Biog.
}

Specific Charucter-Bill, along the gap, one inch and a quarter; tarsi one and three-sixteentlis; length of tail three inches. Adult with bristly feathers over the nostrils, dull yellow; upper part of head and hind neck glossy black; over the eye a band of white, passing on the occiput, where there is a transverse band of scarlet ; a broad black band behind the eye; from the corner of the mouth a white band, continuing nearly the length of the neck-broader at its termination; from the base of the lower mandible a black band, continuing down the sides of the neck, curving backwards about the middle of the neck, and terminating on the upper portion of the side of the breast; upper parts black, tinged with brown behind; the feathers along the middle of the back tipped with white, which color cccupies a large portion of those on the fore part of the back; wings brownish black, the quills spotted with white; on both webs, four middle tail feathers black, the outer white-the next with a spot of black at the base on the inner web-ihe third with a portion 
of the outer web white; lower parts dull grayish-white. Lengih eight inches and three quarters, wing four and three quarters.

The formation of this class of birds is admirably adapted to their habits; furnished with hard and strong bills, they have always at hand a suitable instrument for rernoving the bark of trees, under which lurk their prey-which, as soon as discorered, they quickly extract by darting into the sap their long, sharp, and barbed tongues.

The Woodpeckers are excellent climbers; and for that purpose, their short, strong legs, and hooked claws, are well calculated, and assisted by their rigid tail feathers, are enabled to remain firmly attached to the tree when engaged in dislodging the concealed treasure. They are usually observed moving about the trunks of trees, or creeping along the branches, sounding the bark as they pass over it, in search of decayed parts; and when this employed, or when stripping off the bark by repeated strokes of their powerful bills, their loud knocking is heard a quarter of a mile or more in the woods.

The eggs of all the Woodpeckers are pure white, smooth, and shining, and are deposited in the hollow of a tree. When a convenient situation does not offer, they form similar nests by exeavating to the depth of several inches-which labor is performed with their bills, and usually applied to the decayed pats of trees.

The flight of the Woodpeckers is uneven; after making a few movements with their wings, they draw them close to their bodies, and without any apparent effort, pass through the air with considerable velocity, gradually lowering until the impetus is about exhausted-when they again use their wings, ascend, and cóntinue onwards as before, performing their flight in a jerking or undulating manner.

With us, the Hairy Woodpecker is a constant resident; it is distributed through the woods and orchards, and like the rest of its tribe, feeds chiefly on insects and their larræ. 


\section{PICUS CANADENSIS-GMEL。}

\section{CANADIAN WOODPECKER.}

Great Spotted Woodpecker, Picus septentrionalis, Nutt. Man. Picus (Dendrocopus) villosus, Hairy Woodpecker, Sw. \& Rich. Canadian Woodpecker, Picus Canadensis, Aud. Orn. Biog.

Specific Character-Bill along the gap one inch and three eighths; tarsi seven-eighths of an inch; tail three inches and a half long. Adult with the nostrils covered with dull yellow, bristly feathers; crown black; over the eye a white band passing into scarlet on the occiput ; behind the eye a band of black continuing down the middle of the hind neck; from the corners of the mouth a band of white, which becomes broader as it terminates on the shoulders; at the base of the lower mandible a black band, which passes down the sides of the neck, terminating on the sides of the breast, inclining forward at its termination ; back and wings black, in the middle of the former some of the feathers are white, the latter spotted with white; these markings are rather larger than those of the Hairy Woodpecker ; tail black, the outer two feathers white, with a spot of black at their bases; the next feather with a portion of the outer web and a spot near the end of the inner web white, as are the lower parts of the body. Female with the red occiputal band wanting. Length ten inches, wing five and an eighth.

The plumage of this bird is so like that of the Hairy Woodpecker, that were it not for its superior size, it would scarcely be distinguishable; its voice, however, is much harsher-the head much broader, with the bill stronger - the recumbent feathers at its base longer, and more thickly furnished - the spots on the wings larger, and the middle tail feathers extended an inch and a half beyond the wings-while those feathers of $P$. villosus scarcely appear one inch beyond the wings. It is not so plentiful as the preceding, to which its habits are similar. 


\section{( 177$)$ \\ PICUS PUBESCENS-LINN. \\ DOWNY WOODPECKER.

\author{
Downy Wnodpcker, Picus pubescens, Wils. Amer. Orn. \\ Picus puhescens, Bonap. Syn \\ F'ıcus punescens, Downy Woodpecker, Sw. \& Rich. \\ Downy Woodpecke:, Nutt. Man. \\ Duwny Woodpecker, Picus pubcscens, Aud. Orn. Biog.
}

Specific Character-Bill, along the gap; three quarters of an inch; tarsi five-eighths; length of tail two inches and five-sixteenths. Adult with the upper part of the head glossy black; a white band over the eye; a scarlet band on the hind neck; a black band from the eye passing back on the hind neck; a similar band from the corners of the mouth passing down the sides of the neck; between these two there is a white band, which is much broader at its termination on the hind neck; upper parts black, the middle of the back marked with white-spots of the same color on the wings ; middle tail feathers black-the next with a white spot on the outer web-the adjoining one with the larger portion of the outer web, the tip, and a spot near the end of the inner web white, which color predominates on the rest. Female without the scarlet on the hind neck; lower parts soiled white. Length six inches and three quarters, wing three and five-eighths.

T'his small species resides with us throughout the year and is the most industrious of its tribe. It is always observed moving about the bodies of trees, or creeping along the branches, diligently at work dislodging lurking insects that are concealed between the bark and the wood; while thus engaged, it labors with much energy and activity, frequently spending several minutes at one spot, rather than suffer the vermin to continue unmolested their work of destruction. On such occasions it becomes so intent on its occupation as to allow you to approach quite near the scene of its operations. Having accomplished its purpose, it looks wistfully round and finding you too near for its safety, moves off, uttering a shrill note as it flies to a neighboring tree. 
This species is very abundant in the western forests, and is a favorite mark for the hunters to practice at with their rifles. The precision with which they place a ball through the body of, [as it is termed by them,] the Sap-sucker, at sixty or eighty yards' distance, is surprising.

$P$. Bairdii we have not observed here. It differs from $P . P u b$. escens by having the upper part of head red.

\section{PICUS VARIUS-LINN.}

\section{YELLOW-BELLIED WOODPECKER.}

Yellow-bellied Woodpecker, Picus varius, Wils. Amer. Orn.

Picus varius, Bonap. Syn.

Picus (Dendrocopus) varius, Yellow-billed Woodpecker, Sw. \& Rich. Yellow-bellied Woodpecker, Nutt. Man.

Yellow-bellied Woodpecker, Picus varius. Aud. Orn. Biog.

Specific Character-Bill, along the gap, one inch; ridge of the upper mandible distinct; tarsi three quarters of an inch; tail three inches and a quarter; abdomen yellow. Adult male with the crown and throat bright red, both bordered with black; a large patch of the same color on the fore neck; a band of white from the bill below the eye; a similar band over the eyes meeting on the hind head; upper parts black, tinged with blue and barred with white; tail black, the inner webs of the middle feathers with white bands; sides of the body undulated with dusky; rest of the lower parts yellow. Female, with the throat white, and the yellow on the lower parts paler. Young, without the red markings on the head and throat, which are dusky - the latter lighter; the black patch on the fore neck wanting; the upper parts similar with the adult, but duller; lower parts dull yellowish-gray, undulated with dusky; the abdomen dull yellowish; tail variegated with white. Length eight inches, wing four and a quarter.

On Long Island this handsome bird is not very common, neither does it remain throughout the winter. It frequents similar situations with the preceding, and at times both are seen pursuing their respective occupations on the same tree. 


\section{PICUS CAROLINUS-LINN.}

\section{RED-BELLIED WOODPECKER.}

Red-bellied Woodpecker, Picus Carolinus, Wils. Amer. Orn.

Pıcus Carolinus, Bonap. Syn.

Red-bellied Woodpecker, Nutt. Man.

Red-bellied Woodpecker, Picus Carolinus, Aud. Orn. Biog.

Specific Character-Bill, along the gap, one inch and five-sixteenths; tail three quartcrs of an inch; length of tarsi three inches and a half; upper parts transversely barred with white and black ; abdomen red. Adult male with the upper part of the head and hind neck bright carmine; sides of the head, sides and fore part of the neck and the lower parts, dull grayish-white, tinged with dull yellow; abdomen red; breast faintly tinged with the same, as are the feathers about the base of the lower mandible; upper parts transversely banded with black and white; tail black, the outer feathers with white bands, which color extends along the shafts of the inner webs of the middle pair of feathers about two thirds of their length; the inner webs white, banded with black. Female, the red wanting on the crown, which is ash-gray; the red on the hind neck paler, and the abdomen faintly tinged with red. - Length ten inches, wing five inches and three-eighths.

This species, not very abundant with us, seems to prefer passing its time in the lonely part of the woods. I have never seen it on the ground, or among the early fruit trees. In autumn it resorts to the chestnut trees, the produce of which it appears very fond. Abou the first of May the female commences laying; the eggs are five in number, and are, as usual, pure white. 


\title{
PICUS ERYTHROCEPHALUS-LINN.
}

\author{
RED-HEADED WOODPECKER.
}

Red-headed Woodnecker, Picus erythrocephalus, Wils. Amer. Orn. Picus eryihrocephalus, Bowap. Svn.

Melanerpes ervithrocephalus, Red-hcaded Woodpecker, Sw. \& Rieh.

Red-headed Woodpecker, Picus erythrocephalus, Aud. Orn. Biog.

Specific Character-Adult, head, neck, all round, and fore part of breast, crimson ; secondaries white, at base black, of which cc: lor are the spots and the tail feathers. Young with the head and neck blackish-gray. Adult with the head and neck all round bright crimson, edged with black on the lower neck; back, scapulars, wing coverts, primaries, outer secondaries, and tail feathers, glossy bluish-black; rump and lower parts, with a large patch on the wings formed by the inner secondaries, pure white.Length of male nine inches, wing five and three-eighths. Female smaller.

The Red-headed Woodpecker is rendered conspicuous by its bright, varied, and distinct colors. With us, it is not as abundant as it was a few years since; formerly it was one of our most common Woodpeckers, but now it seems less plentiful. In the northern part of the State of New York this species is more abundantand I found it quite common in the vicinity of Utica.

The Red-headed Woodpecker arrives among us early in the month of April, and during the spring, its favorite resort is among the heary timber. At this season it subsists chiefly on insects. In the summer it frequents the fruit-trees, ripe cherries and pears seeming to be a favorite repast. In the fall it feeds on berries and acorns, the latter at this season forming a large portion of its food. Late in autumn it migrates southward, though in sheltered situa. tions I have occasionally observed it during winter. 


\section{PICUS AURATUS-LINN}

\section{GOLDEN-WINGED WOODPECKER.}

Golden-winged Woodpecker, Picus auratus, Wils. Amer. Orn.

Picus auratue, Bonap Syn.

Culaptes auratus, Golden-shafted Woudpecker, Sw. \& Rich.

Flicker or Golderiwinged Wondpecker, Nutt. Man.

Golden-winged Woodpecker, Picus auratus, Aud. Orn. Biog.

Specific Character-A broad black band on the fore neck; lower parts distinctly marked with round black spots; under surface of wings and tail golden yellow. Adult with the upper part of head and hind neck ash-gray ; a band of carmine on the latter ; a black patch on the sides of the throat; cheeks, throat, sides and fore neck pale purplish-red; back, scapulars, and secondaries light greenishbrown, barred with black; rump white; tail coverts whitish, marked with black; primaries and tail feathers blackish-brown; their shafts, as well as those of the secondaries and tail corerts yellow ; those of the tail feathers black toward the end; a large patch of black on the fore part of the breast; lower parts reddish-white, tinged with yellow, deeper on the abdomen, and handsomely marked with round spots of black; lower surface of the wings and tail feathers yellow, the latter deeper and black toward the ends. Female with the black markings wanting on the sides of the throat. Length twelve inches and a half, wing six and one-eighth.

This handsome bird is well known by a variety of names, such as "High-hold," "Wake-up," and "Flicker," by some it is called "English Woodpecker." It is very generally distributed over the United States, and with us it is only partially migratory.A few remain during the winter. During spring it subsists on insects, which it collects on the ground, and with its strong bill penetrates the decayed branches of trees in search of a further supply of food. During the summer, when small fruits ripen, such as cherries and berries, it prefers this rich and nourishing fare, and makes an enemy of the farmer by visiting the corn-fields, and regaling on 
the young and tender ears. In the fall it resorts to the "pepperage trees," the berries of which, at this period, it feeds on.

This species is nearly allied to the Red-shafted Woodpecker, (Picus Mexicanus,) a specimen of which I received from Texas, but does not visit the United States. It differs from the Goldenwinged Woodpecker in the color of the under surface of the wings and tail feathers, that being of a reddish-orange, and the patches on the sides of the throat crimson, while the former of those parts in ours is yellow, and the latter black. In other respects they are not unlike.

\section{F A M I L Y C U C U L I N}

\section{CUCKOOS.}

\section{GENUS COCCYZUS-LINN.}

\section{CUCKOO.}

[Bill of moderate length, rather strong, compressed, acute, curved; neck rather short; body slender; wings of moderate length; tail very long, graduated ; toes slender.]

\section{COCCYZUS AMERICANUS-LINN.}

\section{YELLOW-BILIED CUCKOO.}

Yellow-billed Cuckoo, Cuculus Carolinensis, Wils. Amer. Orn.

Coccyzus Americanus, Bonap. Syn.

Yellow-billed Cuckoo, Coccyzus Americanus, Nutt. Man.

Yellow-billed Cuckoo, Coccyzus Americanus, Aud. Orn. Biog.

Specific Character-Upper mandible brownish-black; the sides at the base, whole of the lower, except a small portion toward the end, yellow; the tail feathers, except the middle pair, brownish black, toward their ends white. Adult with the bill brownish-black above, with the margin of the upper, and nearly the whole of the lower mandible and the eyelids yellow; upper parts dark drab, lighter on the head; inner webs of the wing quills bright cinnamon; tail feathers black, largely tipped with white, excepting the middle pair, which are of the same color as the back, rather more deeply 
tinged with green, and a portion of the outer webs of the first two white; lower parts, with the sides of the neck and breast, tinged with pale bluish-gray. Length twelve inches, wing six.

By many the American Cuckoo is charged with the unnatural conduct in relation to its progeny, which is so disreputable to the European species; that of depositing its eggs in the nest of other birds, to whose mercy and care they are abandoned. If he who is still of this opinion, will take the pains to observe the habits of this much slandered bird, during his rambles in the woods and orchards in the month of June, he will find a nest, composed of small sticks and weeds-placed on the branch of an apple tree, or in some lonely part of the woods, that contains three, and sometimes four eggs, of a greenish blue color, on which the female Cuckoo is sitting, patiently waiting the time required for incubation. Scon after its arrival from the South, which is about the middle of May, it begins to pair and scatter about the woods and orchards, picking up a bountiful supply of insects and berries, from which it obtains support.

\section{COCCYZUS ERYTHROPHTHALMUS-WILSON.}

\section{BLACK-BILLED CUCKOO.}

Black-billed Cuckoo, Cuculus erythrophthalmus, Wils. Amer. Orn. Cocryzus erythrophthalinus, Boisap. Syn.

St. Domingo Cuckoo, Coccyzus Dominicus, Nutt. Man.

Black-billed Cuckoo, Coccyzus erythrophthalmas, Aud. Orn. Biog.

Specific Character-Bill black; all the tail feathers light brown, tinged with green and tipped with white. Adult with the bill wholly black; upper parts light brown; tinged with green; all the tail feathers the same color as the back tipped with white; inner webs of the wing-quills pale reddish-brown; lower parts white, tinged with yellow; the eye surrounded by a bare, wrinkled skin, bright red. Length eleven inches and a half, wing five and three quarters.

This species is about as common among us as the former, and ranges over the same extent of territory. From its general resemblance to the preceding, it might very easily be confounded with that species by a casual observer. 


\section{F A M I Y C O L U M B I N E. PIGEONS. \\ GENUS ECTOPISTES-SWAINSON. \\ LONG-TAILED DOVE.}

[Bill short, rather slender, straight-broader than high at the base; head small; neck of moderate length; body rather slender; fcet short ; tarsus as short as the hind toe and claw-the upper half clothed with feathers; inner toc longer than the outer.]

\section{ECTOPISTES MIGRATORIA-LINN.}

\section{WANDERING LONG.TAILED DOVE.}

Passenger Pigeon, Columba migratoria, Wils. Amer. Orn.

Columba mig atoria, Bonap. Syn.

Colur,ba (Ectopistes) migratoria, Sw. \& Rich.

l'assenger Pigeon, Nurt. Man.

Passenger Pigcon, Columba migratoria, Aud. Orn. Biog.

Specific Character-Tail consisting of fourteen feathers: irides red. Adult male with the bill black; head and hind neck slate color; lower part of the hind neck and sides of the neck changing to golden green and crimson; fore neck and breast brownish-red; abdomen and lower tail coverts white; tail feathers light blue at the base, terminating with white; a black band on the inner webs at the base, the middle pair of that color; upper parts blue, liglifter on the hind part of the back; wings dark brown, margined with white coverts slate color, spotted with black; sides of the body light blue. Female smaller than the male, with the upper parts inclining to yellowish-brown; lower parts dull white; the breast tinged with yellowish-brown. Length sixteen inches, wing eight.

The Common Wild Pigeon is said to inhabit North America from the Gulf of Mexico to Hưdson's Bay. Many are said to remain at the latter place as late as December, its migrations depending entirely upon the supply of food. It makes casual visits to all parts of the United States, but is no where so abundant as [spoken of by Wilson and Audubon] in our western forests; where it is attracted 
by the Beech-nuts, which constitute the chief food of the Wild Pigeon. "It sometimes happens, that having consumed the whole produce of the beech trees in an extensive district, they discover another at the distance of perhaps sixty or eighty miles, to which they regularly repair every morning, and return as regularly in the course of the day, or in the evening, to the place of general rendezvous, or, as it is usually called, the roosting-place. When they have frequented one of these places for some time, the appearance it exhibits is surprising; the ground is covered to the depth of several inches with their dung, and the tender grass and underwood destroyed; the surface strewed with large limbs of trees, broken down by the weight of these birds clustering one above another-and the trees themselves, for thousands of acres, killed as completely as if girdled with an axe. The marks of this desolation remain for many years on the spot; and numerous places could be pointed out, where, for several years after, scarcely a single vegetable made its appearance."

'The flight of the Wild Pigeon is estimated at the rate of a mile in a minute. I have been informed by ship-masters, that they have occasionally seen large flocks of pigeons drifting about at sea. The supposition is, that they have lost their way, or have been driven out to sea, and becoming fatigued, have alighted on the water, and perished.

The nest is formed of a few dry sticks, put together with but little attention to its structure. 'The eggs, two in number, are pure white.

I have heard frequent controversies relative to the number of eggs deposited by the Wild Pigeon. I can assure those who are of opinion that it lays but one egg, that the number is as stated above, though generally but one young bird is found in the nest. This is accounted for by the inequality of the hatchin $x$; one usually precedes the other a few days - and the remaining egg or young, as soon as it appears, is thrown from the nest by the first comer. 


\section{ECTOPISTES CAROLINENSIS-LINN.}

\section{CAROLINA LONG-TAILED DOVE.}

Carolina Pigeon or Turtle Dove, Columba Carolinensis, Wils. Amer. Orn. Columba Carolınensis, Bonap. Syn.

Carolina Pigeon or Turtle Dove, Nutt. Man.

Carolna Turtle Dove, Columba Carolinensis, Aud. Orn. Biog.

Specific Character-Tail consisting of fourteen feathers ; irides ha. zel. Adult male with the bill black; upper part of head, and hind part of neck and wings, slate blue; fore neck and breast light purplish-red; sides of the body and lower wing coverts light blue; lower parts pale yellowish-white; legs and feet bright red; upper parts yellowish-brown; lower parts of the hind neck, and sides of the neck, reflecting vivid tints of golden green and crimson; tail feathers long, at their bases dark bluish-toward the end white, which color occupies about one inch on the outer four, diminishing on the next two; the middle pair longer, of a plain yellowishbrown color the entire length. Length of male twelve inches, wing five and a quarter.

Female smaller, with the reflections on the neck less brilliant, and the crown faintly tinged with blue.

During the spring and summer months, the Turtle Dove is very generally distributed over the country. At the North it does not associate in any considerable numbers, being generally seen flying about in pairs. The flight of the Turtle Dove is swift, and accompanied by a whistling noise, produced by the wings. It alights on fences, trees, or on the ground, and feeds on seeds and berries of various kinds. Its flesh is superior to the preceding species, but not being ranked as game, it is but seldom pursued by sportsmen; and not disturbing the crops of the farmer, it is but seldom molested. So tender is the skin of this bird, that when shooting it from trees, even a slight fall is apt to so much displace the feathers as to render it unfit for the cabinet; and by collectors it is considered one of the most difficult birds to preserve. It commences building 
its nest about the middle of May, selecting the woods and orchards for this purpose. The nest, though rudely made, is constructed with rather more art than that of the common Wild Pigeon. The eggs are two-pure white. In autumn it migrates southward, and it is said congregates in large flocks during winter.

\section{F A M I L Y P E R D I C I N E.}

\section{PARTRIDGES.}

\section{GENUS ORTYX-STEPHENS.} PARTRIDGE.

Bill short, thick-head small-neck rather short-body full--wings shortrounded-tail short, rounded-tarsi naked, shorter than the middle toe.]

\section{ORTYX VIRGINIANA-LINN. \\ COMMON AMERICAN PARTRIDGE.}

Quail, or Partridge, Perdix Virginiana, Wils. Amer. Orn.

Perdix Virginiana, Bonap. Syn.

American Partridge, or Quail, Nutt. Man.

Virginian Partridge, Perdix Virginiana, Aud. Orn. Biog.

Specific Character-Male, a broad band from the base of the upper mandible passing over the eye down the side of the neck, and a large patch on the upper part of the fore neck, curving on the sides of the neck, white. Female with a band over the eye, and the upper portion of the fore neck, curving on the sides of the neck, brownish-yellow. Adult with the bill short, strong, black; crest short; forehead, and a broad line over the eye, continuing down the sides of the neck, and a patch on the upper part of the fore neck, white; crown brownish-red, bordered and marked with black; a band from the base of the bill, curving down the sides of the neck, becoming very broad on the fore neck, black; neck all round light reddish-brown; the feathers on the sides of the neck spotted with white, and marked with black; upper parts reddishbrown, variegated with black, gray, and yellowish; sides of the 
body chestnut; breast tinged with yellow ; abdomen white, which, with the breast, is marked with curved bands of black; lower tail coverts brownish-red, spotted with white, with central arrow-head shaped, black markings; tail bluish, freckled toward the end with brownish-sed, dusky, and dull white. Length nine inches and a half, wing four and seven-eigliths.

Before Ornithological observations were made to any extent in this country, it was by many supposed that the American Partridge was identical with the European Quail, which name has been bestowed upon it and continued generally, in the State of New York and in the Eastern States, to this day; and at this time, there are some who consider it a variety of the European species, and attribute the difference in size and markings to the effect of climate.

To those persons who are in the habit of comparing birds, only a slight comparison is necessary to convince them that this bird is peculiar to America. It is at least one-third larger than the European Quail, with the bill, tarsi, and feet much stronger -the tail feathers longer and of a different color, as is its general appearance, although in form it resembles the Quail of Europe. Naturalists having placed this class of North American birds under the Genus Ortyx, (Partridge,) we have, therefore, properly speaking, no Quail in this country.

Four species of Partridge are known to inhabit North Americathe California, (Ortyx Californica,) Plumed, (Ortyx plumifera,) and Welcome, (Ortyx neoxenus,) have only been found in the western part of the continent. The present, the only species found within the limits of the United States, is very generally distributed throughout the Union, though more abundant in the interior. In the month of January, I met it in great numbers in the States of Indiana and Ohio. In the Western States, shot guns and pointer dogs are but little used. The hunters find sufficient employment for their rifles among larger game, and consider the common American Partridge too insignificant to waste their ammunition upon, while their tables are supplied with the savory flesh of the Wild Tur. key and Deer. Thus this species continues to multiply, having nothing to contend with except the severity of the wea- 
ther, or an occasional descent made upon it with nets, though this unsportsmanlike mode, particularly in the interior, is but seldom practised. As its fiesh is not so highly prized as by the fastidious palates of our city epicures, and being so plenty, and so far removed from the markets of the river towns, as a source of gain it would prove unprofitable.

On Long Island it is quite abundánt, notwithstanding this famous shooting ground is visited annually by a great number of sportsmen, and were it not for the hospitable cover, which, in many places, is so close as to defy its pursuer and his dogs, it would long since, like the Pinnated Grouse, have been exterminated from the Island.

About the middle of April, the male perched upon a fence or branch of a tree, whistles his clear and well known call; having chosen his mate, they retire to some appropriate place to build their nest, usually selecting a tuft of rank grass for that purpose. The nests which I have found contained from eight to fourteen plain white eggs, and it is said that as many as twenty-four have been found in one nest. About the last of June the eggs are hatched, and by the 25th of October, are considered in good order for shooting. Mr. Audubon states that in Texas, the Floridas, and as far east as the neighborhood of Charleston, South Carolina, it breeds twice in the year, first in May, and again in September; and with us it is by many believed that it rears two broods. With those who are of this opinion, I am inclined to disagree. During the season of shooting, we notice quite a difference in the birds of the year, I admit. The younger of these, I am disposed to think, are the first offspring of their parents, which are later in hatching than those that have bred for several years, or it may occur when the nest has been broken up before the eggs were hatched; and in persisting to raise a brood, the female may lay a second time; but in general I am well persuaded that they do not, with us, rear but one brood during the year.

The flight of the Partridge is performed by a quick flapping of the wings, and it is capable of sustaining itself in the air for a considerable time. There is a notion prevailing among some of our sportsmen that the Partridge is not capable of continuing its flight 
over thirty or forty rods without alighting, and in conversation they have illustrated their remarks by stating that they had seen it, when attempting to cross a stream not over half a mile wide, fall in and perish. Such occurrences may have taken place when families were about changing their location. The younger birds becoming tired, have induced the older ones to alight with them, and not being able to arise from the water, nor having sufficient strength to swim to the shore, have perished. In autumn, after the crops are gathered, it gets in fine condition from feeding on the scattered seeds; its flight is then strong and swift, and at this season it requires an active gunner to shoot it. I think I can say with certainty, that I have seen it move off at least one mile without halting, judging from the ground I went over before putting it up again.The gun is not the only means used for its destruction; traps and snares of various kinds are set all over the Island, by persons who are eager to profit by the ready sale of these resident birds. Its flesh is white, tender, and rather dry, and in general highly esteemed, though as game it is quite inferior to the Woodcock or Wilson's Snipe. In severe winters it suffers by deep snows, and at such times it becomes quite tame, approaches the barn, and shares with the poultry. A few years since, a bevy of sixteen was in daily attendance at the farm at which I was staying. They were fed with corn and wheat, of which they are fond, as well as buckwheat, berries, and insects. In a few days they became very familiar, walked into the barn, and ran about the floor to pick up the refuse grain. After having made their repast, they went to roost on the snow, at a short distance from where they were fed, with apparently as little timidity as the domestic fowls. When roosting, they adopted the form of a ring, with their heads out, and lying thus in a close body, received the mutual warmth of each other. The eggs of the Partridge have been frequently hatched by the domestic hen; the birds have remained with her during the first season, but on the return of spring, obeyed their native instinct and took to the fields-although it is the opinion of naturalists, that with proper care they could be domesticated. With sportsmen, the Partridge is proverbial for lying close; incidents occurring when it has suffered itself to be caught by the dog. 


\section{F A M I L Y T E T R A O N I N}

\section{GROUSE.}

\section{GENUS TETRAO-LINN.}

\section{GROUSE.}

[Bill short, robust, feathered at the base, covering the rostrils; head small; body full; wings short, rounded; tail of moderate length, rounded-the feathers broad ; tarsi feathered; feet stout, of moderate length.]

\section{TE'TRAO UMBELLUS-LINN.}

\section{RUFFED GROUSE.}

Ruffed Grouse, Tetrao umbellus, Wils. Amer. Orn.

Tetrao umbellus, Bonap. Syn.

Tetrao umbellus, Ruffed Grouse, Sw. \& Rich.

Ruffed Grouse, Nutt. Man.

Ruffe.t Grouse, Tetrao umbellus, Aud. Orn. Biog.

Specific Character-Lower portion of tarsi naked; length of tail six inches and five-eighths, fan-shaped, a broad black band near the end. Adult male, with the head and neck variegated with yellowish-red, and grayish-white; sides of the neck furnished with a tuft of black feathers-a few of the upper ones tipped with dull white-the rest tipped with dark green; the feathers on the back with a central white spot, surrounded with black, which color is broadly margined with reddish-brown; all the feathers tipped with ash gray, and the entire plumage of the back minutely spotted with black; quills brown, their outer webs pale yellowish-red, spotted with dusky; tail long, fan-shaped-the feathers broad, and beautifully marked with transverse bars of black, pale yellowish-red, and grayish-white; a broad black band near the tips, which are grayish white, finely dotted with dusky; lower parts yellowish-white, barred with brown; from the nostrils a yellowish-white band, continu- 
ing behind the eye; bill horn color, lighter below; eye reddish hazel; throat and fore neck light brownish-yellow. Female with the plumage duller-the crest and tufts on the sides of the neck less. Length eighteen inches, wing seven and a quarter.

This species of Grouse is well known in the State of New York by the name of Partridge; in the Western States it has received the appellation of Pheasant. It is said to be very plentiful on the plains of the Saskatchewan, and is found in almost every part of the United States; though in the Southern States it is not so common; according to the observations made by Mr. Audubon, it does not inhabit Louisiana.

On Long Island it is quite plentiful, inhabiting generally the middle portion of the Island, particularly the chain of hills known as the "Spine," which, from its formation, is best adapted to its habits. It prefers a mountainous region, covered with wood, and watered with running streams. I have procured a number in Duchess county, on the rough lands adjacent to the Hudson River ; in Orange county, west of Newburgh, they are abundant, and are also found in large numbers in the mountainous country that borders the valley of the Delaware. In several of the Western States I have met with it, but no where in such abundance as in the State of Indiana, a short distance from the Wabash river, in the district of country lying between Vincennes and Terra-haute.

Early in the month of April, the Ruffed Grouse begin to pair ; at this season, the male, mounted on a log or stump, commences his loud drumming. This drumming sound-so familiar to all persons residing in those districts inhabited by the Ruffed Grouse-is produced by short strokes of the wings, commencing slowly, and gradually running into a quick and rapid beating, producing a sound not unlike the rapid rolling of a distant drum. This manœuvre is generally practiced shortly after dawn, and again at the close of day. Early in May it commences building its nest, which is placed on the ground and formed of dry leaves and grass; the eggs are plain pale brown, the number contained in the nests which I have found, were from seven to ten and it is said a larger number are sometimes found. By the twenty-fifth of October it is considered in good order for shooting, and affords fine amusement for sportsmen. 
When flushed, it springs up with a loud, whirring sound; at other times in a noiseless manner.

The Ruffed Grouse is capable of rapid flight. In the autumn of 1839, while two of my friends were in pursuit of the American Partridge, their dog put up a Ruffed Grouse. Both gentlemen fired at the same instant-and seeing the bird lodge in a tree, both claimed the prize-each supposing that his shot had taken effect. On arriving at the spot, they found the bird impaled on a small dry branch, without having received a single pellet. On one other occasion, a gentleman started a Grouse near Weehawken, New Jersey; before he could fire, the bird dropped dead-on taking it up, he found the skull broken, it having flown against a limb of a tree with such force as to produce instant death.

Its food consists of seeds and berries of various kinds. During winter, when the ground is covered with snow, it resorts to the orchards, and feeds on the buds of apple trees. I have frequently heard it stated, that at the season mentioned above, when the Ruffed Grouse is "budding," as it is termed, six or eight, or as many as should alight on the same tree, could be successively killed, by commencing with the lowermost one. This I have as frequently heard contradicted, and shall offer my own observations on the subject. Several years since, while spending a winter in the northern part of Massachusetts, a section of country where this species abound, I devoted a large portion of my time to Grouse-shooting.On the farm where I was residing, there was an extensive appleorchard, situated at the foot of a mountain. During a deep snow, large numbers of the present species of Grouse, would early in the morning, and again toward evening, descend from the mountain on the trees in the orchard, for the purpose of procuring the birds. Hither I repaired, for the purpose of obtaining the desired game; and having heard my host speak of shooting from ten to twelve from one tree, by taking them in rotation, I of course reckoned on rare sport-and was not a little disappointed on finding, that after having shot one or two, the rest had flown to their secure retreat in the mountain. Communicating the result to my host, he questioned me as to the mode of procedure-and then informed me, that instead of walking through the orchard after the birds had 
settled on the trees, or after having shot one down, advance to take it up, I should take my station in the orchard before they commenced flying-placing myself where I should be least likely to be observed, in such a position that I could load and fire without rising, and let those that I shot lie till the sport was over. With these instructions, at an early hour on the following morning, I again repaired to the orchard-and the result proved satisfactory. When alighting on the tree, they appear exceedingly timid, and spend several minutes in looking widly around them. Not seeing any thing to excite suspicion, they commence filling their crops with the buds-and after waiting until they become fairly engaged in collecting their food-then, by commencing with the lowermost one, all on the tree can be successively shot. At the report of the gun, those above your mark merely start-do not quit the tree-but immediately recommence their occupation. This manner of shooting I do not recommend, nor would I practice it; at the present day it is unsportsmanlike-and at such times, from the scarcity of food, the birds are in very poor condition. The Ruffed Grouse is superior for the table during the month of October. At this season it feeds on a variety of nutritous and wholesome berries, which give its flesh an exceedingly fine flavor. By epicures the young at an earlier period is considered preferable. 


\title{
TETRAO CUPIDO-LINN.
}

\author{
PINNATED GROUSE.
}

\author{
Pinnated Grouse, Tetrao cupido, Wils. Amer. Orn. \\ Tetrao cupido, Bonap. Syn. \\ Pinnated Grouse, Nutt. Man. \\ Pinnated Grouse, Tetrao cupido, Aud. Orn. Biog.
}

Specific Character-Male with tufts of elongated feathers on the sides of the neck, upper parts transversely barred with blackish-brown and yellowish-red; lower parts grayish-white, transversely barred with dull reddish-brown. Female with but a slight trace of the elongated tufts so conspicuous in the male. Adult male with the head slightly crested; on either side of the neck a tuft of rather stiff feathers, under which lie those orange-colored sacks-which, when inflated, are so conspicuous in the male; upper parts blackish brown, transversely marked with pale reddish-brown; tail plain brown, short and rounded, tipped with white; throat pale yellowish white, spotted with pale reddish-brown and dusky; legs covered down to the toes with hairy feathers. Female smaller than the male; the plumage duller; the tail irregularly barred with dull reddish-white and more broadly tipped. Length eighteen inches, wing eight and a quarter.

On Long Island the "Prairie Hen" is very nearly if not entirely extinct. Thinty years ago, it was quite abundant on the brushy plains in Suffolk county, which tract of country is well adapted to its habits-but being a favorite bird with sportsmen, as well as commanding a high price in the New York markets, it has been pursued, as a matter of pleasure and profit, until now it is very doubtful if a brace can be found on the Island. On a recent excursion over its former favorite haunts, I could find no trace of it. In conversation with several of the elder residents, they spoke of 
the "Heath Hen" as being very abundant some twenty or thirty years since, but now consider it entirely extinct. Occasionally it is seen in the neighborhood of Schooly's Mountains, New Jersey; and it is said that some are still found in Orange county, west from Newburgh. In 1836, I found it very plentiful on the prairie lands in the State of Illinois, and have since been informed that it is becoming more scare in that section. It occasionally occurs in Pennsylvania, and is said to range over the whole extent of the barren lands of Kentucky.

The Pinnated Grouse avoid those sections of country that are covered with heavy timber, giving preference to the open dry grounds covered with brush and shrubbery of various kinds. In the month of April, which is the time it begins to pair, the loud notes of the male are heard for a mile or more. At this time, those bright orange-colored sacks on the sides of the throat are most observable, which they seemingly inflate for the purpose of producing this loud tooting sound.

About the first of May it commences building its nest, which is placed on the open ground, in a tuft of grass, or some small shrub. The eggs, which are from eight to twelve in number, resemble in color those of the preceding species.

Its food consists of berries of various linds, and small acorns, the produce of the shrub oak.

At Martha's Vineyard I am informed that it is quite plentiful, and during winter, a few are exposed for sale in the New York markets, procured at that place. Its flesh is quite dark, but is in high esteem, and commands from five to eight dollars a brace. 


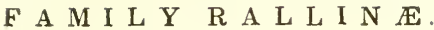

\author{
RAILS. \\ GENUS GALLINULA-BRISS.
}

\section{GALLINULE.}

[Bill about the length of the head, higher than wide, compressed, straighttapering, the base spreading into a naked membrane covering the forehead; head small-neck of moderate length-body full-wings broad, of moderate lengthtail very short, rounded; toes four, hind toe bearing on the grourd; anterior toes long, divided to their origin.]

\section{GALLINULA CHLOROPUS-LINN.}

\section{COMMON GALLINULE.}

Gallinula galeata, Bonap. Amer. Orn.

Florida Gallinule, Gallinula galeata, Nutt. Man.

Common Gallinule, Gallinula chloropus, Aud. Orn. Biog.

Specific Character-Frontal plate, bill, (except toward the point,) and a ring round the tibia, carmine; a few broad streaks on the sides of the body, and most of the under tail coverts white. Adult with the frontal plate and bill carmine, the latter tipped with yellow; head and neck all round purplish-blue; breast and sides of the body dark grayish-blue, the feathers of the latter marked with white; abdomen grayish-white; a few of the lower tail coverts black, the rest white; tail brownish-black; upper parts dark brown -the fore part of the back and wing coverts tinged with olive; eyes bright red. Length thirteen inches and a half, wing six and three quarters.

This species prefers the more temperate parts of the Union. In the Southern States it is quite common during summer, but seldom observed as far as Long Island, on the south shore of which I have known a few to occur; and I have in my possession a handsome 
specimen that was shot on Staten Island. Mr. Baird informs me that it is occasionally observed on the Susquehannah and its tributaries.

The Common Gallinule is usually met with in the vicinity of fresh water streams and ponds. It is exceedingly timid-conceals itself among the rank grass-and, like the Rails, it seldom takes wing, except when performing its migratory flight. When surprised, it runs nimbly - and, if hard pressed, takes to the water, and swims and dives well, although the formation of its feet does not seem calculated for aquatic pursuits, other wading through shallow water. Its food consists of worms, insects, and various vegetable productions that take their growth on low, wet grounds.

\section{GALLINULA MARTINICA-LINN.}

\section{PURPLE GALLINULE.}

Purple Gallinule, Gallinula Porphyrio, Wils.

Gallinuala Martinica, Bonap. Syn.

Purple Gallinule, Nutt. Man.

Purple Gallinule, Gallinula Martinica, Wils. Amer. Orn.

Specific Character-Frontal plate blue; bill at the base carmine, toward the point greenish-yellow. Adult with the head, fore part of the neck and breast, purple; abdomen greenish-black; lower tail coverts white; upper parts green, with golden tints on the fore part of back; inner webs of the quills dusky-outer webs green; sides and hind part of neck, and sides of the body tinged with blue ; irides light red. Length thirteen inches, wing seven.

In the southern part of the Union, the Purple Gallinule is a constant resident. Stragglers occasionally wander along the coast as far as Massachusetts, and the occurrence of this elegant bird on Long Island is exceedingly rare. According to Wilson, it makes its appearance on the sea islands of Georgia in the latter part of April, and after spending the summer, it departs with its young to its winter residence. 
"It frequents the rice fields and fresh water ponds in company" with the preceding, whose general habits it resembles."

In severe stormy weather, these birds are sometimes driven to sea. Recently a statement was given in one of the daily journals, of a bird having flown on board a vessel while off the southern coastfrom the description, I have no doubt that it was an individual of this species.

Since writing the above, I have seen an adult male and female, that were met with at sea, when three hundred miles to the southward, and eastward from the Balize. It does not seem that they were travelling in company, fourteen hours elapsing between their arrival. The first alighted on the vessel-the second, in attempting to alight, fell into the sea, so much exhausted that it could not rise. Attached to the end of a line, a log was thrown over, which it succeeded in gaining - and by this means was taken on board.It fell into the water a short distance astern of the ship-the vessel moving slowly at the time, favored its escape. In a short time they recruited, and arrived in New York in good condition. The gentleman to whom they were presented, informed me that he fed them with meal, fish, bread, and various articles of diet from the table; he also furnished them with water for bathing, of which they made free use. They appeared to be quite contented in their new home, and seemed to enjoy perfect health until the expiration of three months, when the female was suddenly seized with cramps, and shortly died-the male surviving but a few days after. 


\section{GENUS FULICA-LINN。}

\section{COOT.}

[Bill about as long as the head-higher than broad at the base, corpressedstrong, nearly straight and tapering, the base spreading out into a naked membrane on the forehead-head small-neck slender, of moderate length-body full-wings short and broad-tail short, narrow, and rounded-tarsus shorter than the middle toe ; toes four, very loug, and lobed-fore toes extremely long, bordered by a narrow membrane.]

\section{FULICA AMERICANA-GMEL.}

\section{AMERICAN COOT.}

Common Coot, Fulica atra, Wils. Amer. Orn.

Fulica Americana, Bonap Syn.

Cinerous Coot, Nutt. Man.

American Coot, Fulica Americana, Aud. Orn. Biog.

Specific Character-Frontal plate and bill dull white, the latter with a dusky band toward the end; upper parts deep bluish-gray; lower parts lighter. Adult with a dusky spot on both mandibles toward the end; head and neck grayish-black; lower parts bluish gray, tinged with olive; outer web of first primary edged with white; secondaries tipped with the same; legs bright green.Length thirteen inches and three quarters, wing seven and a half.

In a former part of this volume we have alluded to the improper signification of Coot, given to several species of Sea Ducks. We will now introduce the bird which, according to Ornithological arrangement, is entitled to that appellation.

In the middle Atlantic districts, the Coot is not plentiful, though its occurrence on the sea coast of New Jersey, as with us, is sufficiently frequent to be known to the gunners, by whom the more familiar appellation of "Mud Hen"-or, in some sections of the Island, as at Egg Harbor, "White " or "Henbill," is applied. 
The Coot is found on the low, wet marshes, and on the necks of land along the margins of creeks, which are thickly covered with rank grass and weeds, which afford it shelter during the recess of the tide; at such times it is seldom seen-and if observed, disappears so quickly through the close cover, that it is hopeless to pursue it. At full tide it sits on the drift grass, or retreats to the higher places on the embankment, where it quietly waits the falling of the tide to resume its occupation of collecting insects, worms, and the seeds of various plants, which abound on the mud. dy places it fiequents.

The habits of the Coot are rather sedentary; and like the Rails and Gallinules, to which in habits it has a strong resemblance, it is averse to taking wing - and when not apprised of danger, moves leisurely about in pursuit of its fare. When not thus employed, it assumes a listless and drowsy attitude. When pursued, it runs fast - swims and dives well-and when closely followed, dives quickly; and, when under the water, using both its feet and wings, progresses with considerable swiftness.

I am not aware that this bird breeds on Long Island; but from its retiring habits, its nest might be easily overlooked.

\section{GENUS ORTYGOMETRA-LEACH.}

\section{CRAKE GALI.INULE.}

[Bıll shorter than the head, compressed, robust, higher than wide at the base, tapering, feathered at the base; head rather small-neck rather shori-body compressed.]

\section{CAROLINA CRAKE GALLINULE.}

Rallus Carolinus, Wils. Amer. Orn.

Rallus Carolinus, Bonap. Syn.

Carolina Rail, Nutt. Man.

Sora Rail, Rallus Carolinus, Aud. Orn. Biog.

Specific Character-Bill at base surrounded with black, of which color are the central part of the crown and the middle of the fore neck; back streaked with white, sides of the body barred with the 
same. Young with the black on the head and fore neck wantíng. Adult male with the bill yellow, at the base surrounded with black sides of the neck and fore part of the breast ash gray; abdomen grayish-white; sides of the body barred with brownish-black and white'; a few reddish feathers under the tail; lower tail coverts white; tail dark brown, margined with lighter; hind part of the back blackish-brown, tipped with olivaceous; fore part of the back and scapulars olive-brown, the feathers with central spots of black, margined with white; primaries brown, the outer webs of the first edged with white; wing coverts tinged with olivaceous; hind neck olivaceous, spotted with dusky ; crown brown, with a central band of black. Female similar. Length nine inches and three quarters, wing four and three-eighths.

On Long Island this species is not common, though quite well known to the gunners, who now and then meet with it along the overgrown banks of creeks, and, contrary to its usual custom, it is sometimes observed on the salt marshes. With us, I have never known it to occur in great numbers, a few only halting, when journeying on to the North, on the wet and miry places covered with tall grass and rushes. The most convenient distance for the sportsmen of New York to indulge in the popular amusement of Rail Shooting, is on the Hackensack River, along the reedy margin of which, during the early part of September, it is at some seasons very abundant. The usual manner of shooting Rail on the Hackensack, is similar to that practised by the Long Island gunners when in pursuit of Clapper Rail. Exceedingly timid and retiring in its habits, the "Sora Rail" seeks seclusion among the rank grass; and at low water, although it may be within gunshot, it is rarely seen above the tall plants; and were it not for its shrill and short notes, its habitation, to a casual observer, would not be known. This trait in its habits being known to the sportsman, his excursion is regulated by the state of the tide; and as this lind of shooting cannot last but a few hours, his visits are so timed as to be on the ground before the tide is in. Having provided himself with a light skiff, and secured the services of a person well skilled, 
he anxiously watches the gradual rising of the tide, eager for the sport to begin. Stationing himself in the bow, and his attendant in the stern of the boat, they push off for the scene of operation, fiushed with that peculiar and pleasing excitement attending such excursions. The hapless Rail that was an hour ago feeding in peace and security on the reedy margin of the river, is forced from concealment, the rushes no longer affording it protection; and as the boat advances, it springs up, frequently so near that the sportsman deems it prudent to allow it to pass on to a certain distance before firing. No friendly bough or bush to screen it from the gunner's aim, and its flight being feeble, it is readily shot. It be. ing exceedingly inconvenient, as well as very unsafe, for more than one gunner to occupy a boat, quite a number are sometimes employed within a short distance of each other'; and the zeal each person displays in securing the greatest number, gives a zest to the amusement, which is continued until the receding tide furnishes shelter to the terrified Rail that have escaped.

In favorable seasons, if the sportsman is a tolerable shot, he will, in the short time between two tides, procure a number sufficient to supply his own table, besides making a delicate pres. ent to a few filends. The pleasure and success of the excursion depend greatly on your attendant. Should he be unskilled in the sport, he will be of but little assistance in marking down. He will splash you from head to foot-wet your gun and equipmentsand if you escape sundry bruises from the awkward manner in which he handles his long pole, or does not overturn the boat, you will come off more fortunate than has been my lot on several oc. casions.

The Sora Rail is very sensitive to cold; and should the sportsman, on rising in the morning, find that a smart frost has occurred during the night, he might as well, for all the Rail that he will procure, give over his anticipated trip.

"Rail Shooting" is an arnusement in which sportsmen delight, though I consider it second-rate sport in comparison with Giouse or Partridge shooting. The constrained and tiresome position in which one is placed in order to keep balanced 
in the tottering skiff, is exceedingly irksome, and does not compare with the exhilarating sport when following a fine and well broken dog through a pleasant country, in search of the game just mentioned, the pursuit of which produces that fine flow of spirits which waits on healthy circulation, and lends a charm to sporting.

In the spring of the year, when passing on to the North, it tarries a short time on its favorite marshes to recruit, and with but little delay continues its journey, which, according to Dr. Richardson, extends to the 62d parallel. At the approach of autumn, it is seen on its return, travelling southward as the season advances.Its migrations at this period extend beyond the southern limits of the Union.

In the markets at New Orleans, during winter, I did not observe this or the former species, but found the Clapper Rail in abundance.

Its choice of food is wild oats, from which its flesh derives an exceedingly delicate flavor. In autumn it gets very fat, and is much sought after by the lovers of good living. In some instances, when frost occurs in the early part of the season, and the weather returns warm, it revisits its favorite haunts, from which it had been driven by the untimely cold. In the early part of October it disappears. On Long Island, it is known to the gunners by the name of English Rail.

\title{
ORTYGOMETRA NOVEBORACENSIS-LATHAM.
}

\author{
YELLOW-BREASTED CRAKE GALLINULE.
}

Rallus noveboracensis, Bonap. Syn.

Yellow-breasted Rail, Rallus noveboracersis, Sw. \& Rich.

Yellow-breasted Ral, Nutt. Man.

Yellow-breasted Rail, Rallus noveboracensis, Aud

Specific Character-Bill, along the gap, five-eighths of an inch; tarsi eleven-sixteenths. Adult male with the upper parts brownish black; the feathers margined with dull yellow, crossed with narrow white bars from the crown the tips of the tail feathers; fore neck 
and fore part of the breast yellowish-brown-the feathers tipped with darker brown; abdomen white; flanks dusky, with white bars; lower tail coverts light red. Female with the plumage duller. Length six inches and three quarters, wing three and a quarter.

Notwithstanding this species is but seldom met with on Long Island, I am not inclined to think it so exceedingly rare in this vicinity as it is generally supposed. In the Southern States it is quite common, and from the remarks made by Mr. Nuttall, we may infer that it breeds on the borders of Fresh Pond, near Boston; and it is stated in the Fauna Boreali Americana, Part II. page 402, from a note taken from Mr. Hutchins' manuscript, "that this elegant bird is an inhabitant of the marshes on the coast of Hudson's Bay, near the efflux of the Severn River, from the middle of May to the end of September."

"It never flies above sixty yards at a time, but runs with great dexterity among the long grass near the shore. In the morning and evening, it utters a note which resembles the striking of a flint and steel. At other time it makes a shrieking noise. It builds no nest, but lays from ten to sixteen perfectly white eggs among the grass." Its habits of skulking among the tall grass and reeds that overgrow the wet and but seldom frequented marshes, as well as its unwillingness to take wing, may, I think, in a measure account for its apparent extreme scarcity with us.

There is another species of Rail, for which I have made many close and thus far unsuccessful searches. I speak of the Least Water Rail, (O. Jamaicensis.) It is said to be not uncommon in Louisana, and has been met with on the marshes in New Jersey, and I have no doubt it will yet be found on Long Island. It can be distinguished from all other Rails, by the dusky color of its plumage, as well as being the least of the Genus, as its name denotes. 


\section{GENUS RALLUS-LINN.}

RAIL.

[Bill longer than the head, slender, thick at the base, compressed head small; neck long; body more compressed than the preceding; wings short, broad; tall very short, rounded, of twelve weak feathers; tarsi rather long, stout; toes four; hind toe small ; fore toes very long, slender-free.]

\section{RALLUS CREPITANS-GMEL.}

CLAPPER RAIL, OR SALT WATER MARSH HEN.

Clapper Rail, Rallus crepitans, Wits.

Clapper Rail, Nuttall.

Clapper Rail, or Salt Water Marsh Hen, Rallus crepitans, Aud.

Specific Character-Bill, along the gap, two inches and three eighths; tarsi one and three quarters ; total length fifteen inches, wing five and three-eighths; iris pale yellow.

Adult with the upper part of the head and hind neck olivaceous brown-a brownish orange line from the bill to the eye; upper parts of the body streaked with greenish-olive and light gray; wing coverts dull olive, tinged with gray-some of the feathers irregularly marked with dull white; primaries olive-brown; secondaries and tail feathers same color as the back; loral space, cheeks, sides, and fore part of the neck bluish-gray, the latter tinged with pale yellowish-brown, of which color is the fore part of the breast; hind part of abdomen, and middle lower tail coverts, undulated with deep grayish-brown and grayish-white; lateral tail coverts with the outer webs white; middle of abdomen grayish-white; irides pale yellow ; lower eyelid white. Female smaller, with the colors duller.

The Clapper Rail, or "Meadow Hen" as it is named by the gunners, resides throughout the year in the Southern States. To the eastward of Long Island it is not common; neither is it so 
plentiful with us as it is on the sea coast of New Jersey, although at some seasons I have found it very abundant on the salt marshes along the south shore of Long Island, at which place it arrives at the latter end of April, or about the first of May, and remains until the latter part of September-a few continuing until the early par $_{t}$ of October. It is almost entirely confined to the low, wet marshes, seeking retirement among the rank grass and reeds.

It is seldom seen flying about, and when pursued, depends on running, which it performs at a rapid rate; and being assisted by the thin, compressed form of its body, passes through the grass so quickly, that unless its pursuer is very expert, it is soon out of danger.

In the latter part of May, it commences building its nest, which is placed on the meadow, and usually built so high, in order to prevent it from being overflowed, that it is readily discovered by those persons who are in the habit of collecting the eggs, which are exceedingly delicate eating. The number generally found in the nest, is ten-of a pale clay color, finely dotted with purple.

We frequently see it making short excursions among the neighboring "kussicks." Should it become alarmed while thus engaged in its aquatic amusement, it instantly disappears by diving. If near the bank, it skulks among the grass. If too far from the shore to reach it by swimming under water, it sometimes clings to the roots of the grass, and in this situation will remain for a considerable time. Its choice of residence being the wet and miry meadows, it is not often pursued by sportsmen, excepting when the meadows are overflown by the unusual high tides which occur after the wind has been blowing heavily from the south-east. The gunners take advantage of these occasions, and put it up by pusining their skiffs over the then sunken meadows. The poor Meadow Hens, having no place of retreat, collect on the drifting grass and sea-weed. Becoming bewildered with the scene, and not knowing whither to go, it suffers the boat to approach within a few yards. Those that escape move on to another mass of drift grass, and are marked down by the gunner, who in a few minutes repeats his fire. Its flight is rather slow. Moving off in a straight line, and having nothing to obstruct the sight, it presents an easy mark, and is readily killed.The sportsman, after pursuing it for a few hours, becomes wearied. 
of this unexciting sport, and returns to the shore, with little to boast of save numbers.

Its food consists chiefly of small crabs, and aquatic insects. In the latter part of the season it is in good condition and well tasted, and by some considered superior to tender chickens.

\title{
RALLUS VIRGINIANUS-LINN.
}

\author{
VIRGINIAN RALL.
}

\author{
Rallus Virginianus, IVils. Amer. Orn. \\ Rallus Virminianus, Bonap Syn. \\ Lesser Clapper Rail, Nutt. Man. \\ Virginian Ratl, Raltus Virginianus, Aud. Orn. Biog.
}

Specific Character-Bill, along the gap, one inch and three quarters, length of tarsi one inch and an eighth; length from point of bill to the end of tail feathers ten inches, of wing four. Female about one inch less than the male. A white line from the base of the upper mandible over the eye; crown, hind neck and back, brownish-black, streaked with olive-brown; wings brown; coverts reddish-brown, lesser coverts barred with white; lower tail coverts, sides of the body and lower wing coverts barred with black and white; abdomen dull white; region of the vent duslky, barred with white; breast and fore part of the neck reddish-brown; throat dull white; sides of the head grayish-blue-darker before the eye.

This species is found in the course of the year throughout most parts of the United States-frequenting the borders of the sea shore, as well as the fresh water streams of the interior, for which it seems to have a great predeliction. It is known to gunners and sportsmen by the name of Fresh Water Marsh or "Mud Hen." It inhabits low situations, usually selecting the reedy margins of water courses and rivulets; and I have observed it on the low salt marshes along the sea coast. In habits and plumage, it bears a greater resemblance to the great Red-breasted Rail, (R.elegans,) than it does to $R$. crepitans, to which its action and manners are not unlike. Sheltered among the reeds and rushes, it escapes observation, except by those who are familiar with its habits, or when accidentally met 
twith by sportsmen when in pursuit of other game. Like the rest of the Genus, it reluctantly takes wing-and when pursued by dogs, trusts to its legs until that mode of progression is deemed no longer safe. It runs with great swiftness, and is capable of continuing its rapid and irregular course through the close grass for several minutes; and if not followed by an active dog, avoids pursuit without exposing itself to the sportsman's aim.

Though not usually observed on water of any considerable depth, still, when safety requires, it swims and dives well; but it prefers wet ground and shallow water, that it can wade through without swimming.

The food of the Virginian Rail consists of aquatic insects, worms, snails, and the seeds of various grasses that are produced on the marshy grounds that it inhabits. Its flesh, though not particularly delicate, meets with ready sale, and it is frequently brought to our markets in the early part of April. According to Mr. Audubon, it is distributed through the country and along the Atlantic shores, from Texas to New Brunswick and Nova Scotia, breeding in all the districts. The eggs, though smaller, resemble in color those of the preceding.

\section{RALLUS ELEGANS-AUDUBON.}

GREAT RED-BREASTED RAIL, ־OR FRESH-WATER MARSH HEN,

Specific Character-Bill, along the gap, two inches and three quarters; length of tarsi two inches; sides and fore part of neck and the breast bright orange-brown; "Iris bright red." Total length of the specimen before us seventeen inches, wing six and three quarters.

Adult, upper part of head and hind neck dull brown; from the base of the upper mandible over the eye a dull white line, terminating with brownish orange; lower eyelid white; loral space, and a band behind the eye dusky; upper parts of the body brownish black; the feathers broadly margined with light olive-brown; wing 
coverts dull chestnut; primaries dark brown; inner secondaries and tail feathers same as the back; throat white; fore part and sides of the neck, with the breast, bright orange-brown; abdomen and sides of the body dark brown, barred with white; tibia and hind part of abdomen pale grayish-brown, faintly barred with darker; lower tail coverts white, with a black spot near the end, the middle feathers black, barred with white.

During my frequent excursions on Long Island, I have not had the good fortune to meet with this large and beautiful Rail, and have only seen one specimen that was procured in that locality, which was shot in the vicinity of Williamsburg, and is now in the valuable collection of George N. Lawrence, Esq., to whom I am indebted for the opportunity of making the above description.

The Red-breasted Rail was first described by Mr. Audubon. From his remarks, we may infer that it was observed by Wilson, and considered by him identical with the Clapper Rail, which it is not unlike Wilson's figure, I think justifies the remark, and I have no doubt that he supposed it to be a fine adult specimen of Rallus crepilans, to which it is nearly allied in form and plumage. On making a close comparison, we find it differs in size and markings-and according to $\mathrm{Mr}$. Audubon, very different in its habits. That gentleman observes that "the Rallus elegans is altogether a fresh water bird, while the $R$. crepitans never removes from the salt water marshes that are met with along our Eastern Atlantic coasts, from the Jerseys to the Gulf of Mexico. The present species is found at considerable distance inland, where it breeds, and spends the whole year; whereas the latter never goes farther from its maritime haunts than the borders of the salt water marshes, and this merely on certain occasions, when driven thither by high tides. The Fresh-water Marsh Hen, besides, is confined to the Southern States-a few stragglers only having been observed farther eastward than the State of Pennsylvania, and these only in fresh water meadows." Hence we may conclude that its occurrence with us is extremely rare. 


\section{F A M I L Y C H A R A D R I N 㤅.}

\section{PLOVERS.}

\section{GENUS CHARADRIUS-LINN.}

\section{PLOVER.}

[Bill short, strong, straight-about the length of the head, which is rather large and prominent in front-eyes large-body full-neck short, and rather thick-wings long-tail rounded, of moderate length-toes, connected at the base, hind toe wanting, or furnishel in its place with a small knob.]

\section{CHARADRIUS HELVETICUS-LINN.}

\section{BLACK-BELLIED PLOVER.}

Black-bellied Plover, Charadrius helveticus, Wils. Amer. Orn.

Charadrius helveticus, Bonap. Syn.

Grey Lapwing, Varellus melanogaster, Sw. \& Rich.

Blach-hellied or Siviss Plover, Nutt. Man.

Black-bellıed Plover, Charadrius helveticus, Aud. Orn. Biog.

Specific Character-Bill stout, along the gap one inch and fivesixteenths, length of tarsi one inch and five-eighths. Adult male with the bill black, strong, shorter than the head; cheeks, loral space, throat, fore neck, breast, with a large portion of the abdomen black; hind part of the abdomen and flanks white; forehead, with a broad band passing down the sides of the neck and breast, white; crown, occiput, and hind neck grayish-white, spotted with dusky; upper parts blackish-brown, the feathers broadly tipped with white; eye encircled with white; tail and upper tail coverts white, barred with black the former tipped with white; lower 


\section{( 212 )}

tail coverts white, the outer feathers spotted with black; primaries and their coverts blackish-brown, the latter margined with white; primary shafts about two-thirds from the base white, tips blackishbrown; part of the inner webs of the outer primaries white; both webs of the inner primaries partially white; secondaries white at the base, margined with the same; feet black; toes connected by a membrane. Female smaller. Young with the upper plumage grayish-brown, the feathers spotted with white; throat, fore neck, and upper part of the breast grayish-white, streaked with dusky; rest of the lower parts white. Length of adult male eleven inches and three quarters, wing seven and a half.

Early in the month of May the Black-bellied Plover arrives among us from its winter quarters. After spending a few days on the sand-bars and beaches, it leaves for the North. In the month of August it returns with its young, which is so different in plumage that by many it is considered a distinct species, being called "Bull or Beatle-headed Plover." Though shy, it is frequently enticed within gunshot by imitating its plaintive note. In autumn, it is distributed along the sea coast, subsisting on minute shell-fish and marine insects, on which it gets very fat. It remains with us until the latter part of September, when it moves southward, its migratory course extending to the southernmost extremity of the Union.

Early in autumn this species is very abundant on Montauk. During the month of September, I met with it throughout my entire route across the hills; but found it more numerous on a large bald place, abounding with grubs, worms, and insects of various kinds, about four miles from the Light-house. On Montauk I also fell in with straggling parties of the Long-billed Curlew, and found the Yellow-shanks, [Totanus favipes,] and Tell-tale, [T. vociferus,] quite abundant. These I found in greaier numbers in the valleys along the margins of pools and ponds. 


\title{
CHARADRIUS MARMORATUS-WAGLER.
}

\section{AMERICAN GOLDEN PLOVER.}

\author{
Golden Plover, Charadrius pluvialis, Wils. Amer. Orn. \\ Clıaradrius pluvialis, Bonap. Svn. \\ Charadrius pluvialis, Golden Plover, Sw. \& Rich. \\ American Golden Plover, Charadrius marmoratus, Aud. Orn. Biog.
}

Specific Character-Bill rather slender; along the gap one inch and an eighth, tarsi one and nine-sixteenths. Adult with the bill black, much slighter than C. helveticus; forehead, and a band over the eye, extending behind the eye, white; upper parts, including the crown, brownish-black, the feathers marked with spots of golden yellow and dull white; quills and coverts dark grayish-brown; secondaries paler-the inner margined with yellowish-white; tail feathers grayish-brown, barred with paler; the central with dull yellow; shafts of the wing quills white toward the end, which, with their bases, are dark brown; lower parts brownish-black, though in general we find it mottled with brown, dull white, and black; lower tail coverts white, the lateral marked with black; feet bluishgray. Late in autumn, the golden markings on the upper parts are not so distinct, and the lower parts are grayish-blue. Length ten inches and a half, wing seven and one-eighth.

This bird is closely allied to the Golden Plover, [C. pluvialis, ] of Europe. The latter is, however, superior in size, as well as having the feathers on the sides of the body under the wings, [the axillars,] white, whereas those feathers in our species are gray, and in the European species which I have had an opportunity of examining, the golden tints appear more numerous, and of a richer color.

The American Golden Plover arrives on Long Island in the latter part of April, and soon passes on to the northern regions, where it is said to breed. In the early part of September, on its return 


\section{(214)}

from its natal abode, it frequents the Hempstead Plains, Shinnecock Hills, and Montauk, where it feeds on a variety of insects abounding in such places. Grasshoppers seem to be its favorite fare, and when berries can be obtained, they also contribute to its support.

I have occasionally shot it along the shores and about the ponds on the low, wet meadows; but in general it prefers high, dry lands unincumbered with woods. The Hempstead Plains are well adapted to its habits, and during some seasons it is quite abundant on this miniature prairie. It is better known to our gunners by the name of "Frost Bird," so called from being more plentiful during the early frosts in autumn, at which season it is generally in fine condition, and exceedingly well flavored. Commanding a high price in the New York markets, it is eagerly sought after by the gunners, and not requiring the fatigue and exposure attending the shooting of shore birds, it affords much amusement to sportsmen.

On the ground, the Golden Plover displays a great deal of activity, and when observed, often runs with considerable rapidity before taking wing. It is less timid than the Black-bellied Plover, and is easily decoyed by imitating its peculiar mellow note. I have often observed it, when passing in a different direction from that in which I was lying, check its course, wheel round, and present an easy mark.

Its stay with us, as before mentioned, is very short, and as the season advances it returns southward. It associates in flocks, and when migrating, moves off in a regular manner. 


\title{
CHARADRIUS SEMIPALMATUS-BONAP.
}

\author{
AMERICAN RING PLOVER.
}

Ringed Plover, Tringa hiaticula, Wils. Amer. Orn.

('haradrius Semipalmatus. Bonap. Syn.

American Ring Plover, Charadrus semipalmatus, Sw. \& Rich.

Semipalmated Ringed Plover, Nutt. Man.

American Ringed Plover, Charadrius semipalmatus, Aud Orn. B

Specific Character-Bill shorter than the head; base orange color; toward the point black ; a broad band on the forehead white; margined below with a narrow black band, above with a broad band of the same color ; rest part of the head wood brown; lateral toes connected by a membrane as far as the first joint ; inner toes about half that distance. Adult male with the bill flesh color at base, anterior to the nostrils black; a line of black commences at the base of the upper mandible, passes back to the eye, curving downward on the sides of the neck; a band on the fore part of the head pure white; fore part of crown black; occiput wood brown; chin, throat, and fore neck passing round on the hind neck, pure white ; directly below, on the lower portion of the neck, a broad band of black; upper plumage wood brown; primaries blackish-brown; shafts white -blackish brown at their tips; secondaries slightly edged with white on the inner webs; outer webs nearest to the shafts an elongated spot of white; wing coverts wood brown; secondary coverts broadly tipped with white; breast, abdomen, sides and lower tail coverts pure white; tail brown, lighter at the base; onter feathers white-the rest broadly tipped with white, excepting the middle pair, which are slightly tipped with the same. Female similar, with the upper part of the head and the band on the neck brown. Length seven inches and a quarter, wing five.

This species, though smaller, resembles in plumage the Ring Plover of Europe. In the month of May, the American or Semi- 
palmated Ring Plover is seen pursuing its annual journey to the North. It returns to us in the latter part of August. It frequents similar situations with the Semipalmated Sandpiper, with which it is often seen gleaning its fare-and like that bird, admits of near approach. When alarmed, it utters a sharp note. Late in autumn it migrates to the South, and according to Mr. Audubon, spends the winter in the Floridas.

\section{CLARADRIUS WILSONIUS-ORD.}

\section{WIILSON'S PLOVER.}

Wilson's Plover, Charadrius Wilsonius, Ord.

Charadrius Wilsonius, Bonap. Syn.

Wil=on's Plover, Nutt. Man.

Wilson's Plover, Charadrius Wilsonius, Aud. Orn. Biog,

Specific Character-Bill about the length of the head, very strong, wholly black. Adult male with the bill black, strong; a band of dusky from the eye; a band of white on the forehead; directly above a band of black-rest part light brown; throat white; upper part of the neck encircled with white; a broad band of black on the fore neck; lower parts white; outer tail feathers pure white, the next two with a spot of brown toward the end-the rest plain brown, the middle pair longest; upper parts light brown; primary shafts white, with dusky tips; secondaries tipped with white. Female, with the band on the fore neck brown; the black band on the forehead wanting; feet flesh color. Length seven inches and three quarters, wing four and three quarters.

The plumage of this species closely resembles that of the preceding, but it is readily distinguished by having the bill much longer and stouter, as well as the color being black its entire length. With us it is not very common, and when observed is usually in company with the former species, with which its general customs and manners are similar. 


\section{CHARADRIUS MELODIUS-ORD.}

\section{PIPING PLOVER.}

Ring Plover, Charadrius Hiaticula, Wils. Amer. Orn.

Charadrius melodius, Ord.

Piping Ring Plover, Nuit. Man.

Piping Plover, Charadirius melodius, Aud. Orn. Biog.

Specific Character-Bill shorter than the head; at base orange color, toward the end black; fore neck and cheels pure white; bordered above with black; rest part of the head very pale brown. Adult male with the bill short, orange at the base, anterior to the nostrils black; forehead white, with a band of black crossing directly above; upper part of the head, hind neck, back, scapulars, and wing, coverts pale brown; rump white, the central feathers tinged with brown; tail brown, white at base, tipped with the same; lateral feathers pure white- he next with a spot of blackish-brown near the end ; upper tail coverts white; primaries brown; a large portion of the inner webs white; a spot of the same on the outer webs of the inner quills; secondaries white, with a large spot of brown towaid the ends; lower surface of the wings white; a black band round the lower part of the neck, broadest on the sides where it terminates; entire lower plumage white. Female similar, with the band on the neck brown. Length seven inches, wing four and a half.

To the south shore of Long Island the Piping Plover is common. On the north shore of the bay I have seldom seen it. It seems to prefer the sandy beaches and shoals, where it collects small bivalve shells which lie exposed at low water. I have also observed it along the surf feeding on the deposite of the receding wave. It breeds here, making no nest, other than a slight excavation in the sand; the eggs, four in number, are of a pale yellowish or cream color, speckled with brownish black, and are left during fair weather exposed to the sun-the female seldom sitting on them except in stormy weather or at night. 
When pursued, it runs rapidly; if closely followed, it takes wing, uttering a mellow note-though at such times its voice is more shrill than the soft tones it makes when not disturbed. In autumn, like most of the shore-birds, it gets rery fat, and is excellent food. With the bay-men it is familiar by the name of "Beach bird."

\section{CHARADRIUS VOCIFERUS-LINN}

\section{KILDEER PLOVER.}

Charadrius vocilerus, Wils. Amer. Orn.

Charadrius vociferus, Bonap. Syn.

Charadrius vociferus, lilldeer Plover, Sw. \& Rich.

Kildeer Plover, Nutt. Man.

Kildeer Plover, Charadrus vociferus, Aud. Orn. Biog.

Specific Character-A band on the forehead passing back to the eye; a line over the eye, upper part of the neck all round and a band on the lower part of the fore reck. white; above and below the latter a broad black band; rump and upper tail coverts orange red. Adult with the bill black, at the base a band of blackish brown; on the forehead a band of white passing back to the eye, directly above a band of black; rest part of the head brown, with a band of white behind the eye; throat white; a broad band of the same color encircling the upper part of the neck; middle of the neck encircled with black, much broader on the fore neck; below which, on the fore neck, a band of white, followed by a band of black on the lower neck, the feathers of which are tipped with white, of which color are the breast, abdomen, under tail corerts and sides, the latter faintly tinged with yellow; tail rather long, rounded; the outer feathers white, barred with brownish-black, their tips white, with a single spot of blackish-brown on the outer web; the rest pale reddish-brown at the base, changing into brownish-black toward the ends, which are white; some of the inner feathers tipped with yellowish-brown; the middle feathers are plain brown, with a darker spot toward the ends, which are slightly tipped with white; upper tail coverts and rump reddish-brown, the 
latter brighter; upper parts brown, the feathers margined with reddish-brown; primaries dark brown, with a large portion of the inner web white; a spot of the same color on the outer webs toward the tips, excepting the first two ; their coverts blackish-brown, tipped with white; secondaries white, with a large spot of brown toward the ends-their tips, with those of the primaries, white; secondary corerts brown, broadly tipped with white. Length ten inches, wing seven inches.

T'o most persons residing in the country, this species of Plover is familiar by the name of "Kildeer" - so called from the semblance its notes have to those syllables. During summer it prefers the open, dry grounds; at the approach of winter, it descends to the sea shore. On the south side of Long Island it is not so plentiful as it is on the north side, which, from its higher situation, seems better adapted for its summer residence. On a recent pedestrian excursion around the Island, I met with it in various sections, but found it more abundant on a waste piece of ground a few miles from Greenport, in the direction of Riverhead. On this neglected spot a number of Kildeer had assembled, and from their mannerswhich appeared to be more gentle than those I had previously fallen in with-I concluded that they had enjoyed undisturbed possession of this piece of land for a long time; and not wishing to dispute their claim, I did not disturb or interrupt their $€$ mployment of gathering worms and various species of insects, on which they were intently bent; but contented myself with observing their manners, listening to their well known cry, and admiring their beautiful plumage, which appears to better advantage when the bird is flying from you at a short distance from the ground. The handsome and varied markings which occupy the upper surface of the tail feathers-the bright colors of their upper coverts, and the feathers on the rump-with its elegant wings, and the neat attire of the other parts of the body-render it exceedingly pleasing to the eye.

The Kildeer passes the most of its time on the ground, over which, at times, it is seen walking with a rapid gait. It also alights on decayed stumps and rocks, and if not disturbed, it is not unusual for it to remain several minutes in an erect and quiet attitude. In 


\section{(220)}

addition to its food of worms and land insects, it frequents the shallow brooks and pools in search of such as live on the water. On the wing it is very active, and at times mounts high in the air. The nest of the Kildeer is of simple construction, usually formed like that of the Piping Plover, which is a mere hollow in the ground; the eggs, four in number, are cream-colored, marked with brownish black.

By sportsmen, the Kildeer is seldom pursued, though sometimes shot for market; and I have been told that its flesh, especially in the fall, is good eating.

\section{GENUS STREPSILAS-ILLIGER.}

\section{TURNSTONE.}

[Bill storter than the head, strong, tapering, compressed, blunt; neck rather short; body full; wings long, of moderate breadtb, and poinled; tail rounded, rather short, of twelve feathers ; tarsus equal to the middle toe, rather stouthind toe small ; fort toes with a narrow margin, free.]

\section{S'TREPSILAS INTERPRES-LINN.}

\section{TURNSTONE.}

Tringa interpres, Wils. Amer. Orn.

Strepstlas interpres, Bonap. Syn.

Strepsilas interpres, Turnstorie, Sw. \& Rich.

Turnstone or Sea Dotterel, Nutt. Man.

Turustonc, Surepsilas interpres, Aud. Orn. Biog.

Specific Character-Bill black; feet orange; the head and sides of the neck streaked and patched with black and white; fore part of the neck and upper portion of the sides of the breast, black; lower parts, hind part of the back, and upper tail coverts white; rump dusky; rest of the upper parts reddish-brown, motıled with black; primaries dusky; a band across the wings and the throat white. Young with the head and neck all round, fore part of the back, and sides of the breast, dusky brown, streaked and margined with grayish-white; wing coverts and tertials broadly margined with dull reddish-brown. It can at all times be identified by its having 
the throat, lower parts, hind part of the back, and the upper tail coverts white, and the feathers on the rump dusky. Adult with the bill black; throat white; sides of the head mottled with black and white; crown streaked with black on white ground; on the hind neck a patch of white; a patch of black on the sides of the neck, of which color are the fore neck and the sides of the breast; lower parts white; tail blackish-brown, white at the base, of which color are the lateral feathers, with a spot of black on the inner vanes near the end-the rest margined with reddish-brown and tipped with white; upper tail coverts white; hind part of the back white; the feathers on the rump black; fore part of the back mottled with black and reddish-brown; primaries dark brown, inner webs white; secondaries broadly edged with white, forming a band on the wings; outer secondary coverts reddish-brown; inner black -outer scapulars white, with dusky spots; inner scapulars reddish brown. In winter, the colors are duller. Length nine inches, wing five and three quarters.

In this vicinity, this species is better known to the gunners by the name of "Brant Bird;" at Egg Harbor it is called "Horsefout Snipe," from its feeding on the spawn of the King-crab, or "Horse-foot," as the bay-men term it.

Early in the month of April it arrives among us from the Southern States where many pass the winter, and leaves for its bieeding place at the North in the latter part of May. It returns to the sliores of New Jersey and Long Island about September, where it remains until late in autumn. This is not a numerous species. In its habits it is rather solitary, and is seen singly or in small parties at that season, wandering along the beach in search of irisects and minute shell-fish, which it procures by rolling over the small pebbles, from which it receives its name. In the fall, it is generally in fine condition, and esteemed a delicacy. At Egg Harbor, the young of the species are called "Beach Birds." 


\title{
GENUS HAEMATOPUS-LINN.
}

\author{
OYSTER-CATCHER.
}

[Bill longer than the head-hard, s'rorg, compressed towar.? the end; neck moderate; body compact; wings long ; tail short, even; tues moderate, strong -margins rough, connected at the base-hind toe wanting.]

\section{HAEMATOPUS PALLIATUS-TEM.}

Pied Oyster catcher, Haematopus Ostralegus, Wils. Amer. Orn. Mantled Oyster-ca cher, Haematopus palliatus, Nutt. Man.

Anerican Oyster-catcher, Haematopus pallatus, Aud. Orn. Biog.

Specific Character--Length of bill three inches and three quarters, the color red, lighter at the end; head rounded; head and neck all round black; lower parts white; tail short, even, consisting of twelve broad feathers, their basal parts white, terminating with brownish-black; upper tail coverts white; upper parts brown; secondaries pure white, excepting a few of the inner, which are marked with dark brown; irides yellow. Length eighteen inches, wing ten and a half.

With us the Oyster-catcher" is a rather scarce bird, "although during summer a few are found on almost every beach along the whole extent of the sea coast." On the coast of New Jersey and the Southern States, it is more common; and according to Mr. Audu. bon, it occurs from Maine to Labrador, where it breeds, as well as in the Middle States and Carolina.

The Oyster-catcher is generally confined to the sea-coast; in pairs or small parties it frequents the sandy beaches and shoals in quest of its food, which consists chiefly of muscles, small crabs, and marine insects. At low water it is said to visit the oyster-beds, awaiting a favorable opportunity, when the shells open, to thrust in its hard and strong bill, and rob them of their tenants. From its 
name, this would seem to be a very prominent trait of character. Its occurrence with us is so seldom, that I have not had an opportunity of observing its habits as closely as I should wish.

Those which I have procured on the shores of Long Island have usually been single, or at the most at any one time, a pair, ranging between Raynor South and Babylon, in which section I am not aware that oysters are found. It is a shy, vigilant bird, and exceedingly difficult to approach. It flight is swift. On the ground it walks about in a stately manner; when alarmed, it utters a sharp whistling note, and runs rapidly along the beach. Should the pursuit be continued, it takes wing, and passes out of sight.

Notwithstanding its flesh is dark-colored and ill-flavored, it being considered a singular and quite a scarce bird, it is always sent to market when procured by the bay-men, who recognise it by the name of "Flood Gull."

"Like the Gulls, the Oyster-catcher forms no regular nest, but deposites its eggs, which are from two to three in number, on the sand, leaving them in fine weather during day to be hatched by the influence of the sun."

When wounded, it makes for the water, and swims and dives well. In autumn it migrates southward, and is said to pass the winter in Florida, and at that season collects in flocks. 


\title{
F A M I L Y S C O L O P A C I N E
}

\author{
SNIPES. \\ GENUS TRINGA-LINN.
}

\section{SANDPIPER.}

[Bill straight, slender, tapering-compressed toward the end, and but littlo longer than the hedd; neck moderate; body ather full; wings very long and pointed; tall rather short, nearly even; tarsi moderate; hind toe very small, sometimes wanting; fore toes slender, of moderate length, generally divided ]

\section{TRINGA ISLANDICA-LINN.}

\section{RED-BREASTED SANDPIPER.}

Ash-colored Sandpiper, Tringa cinerea, Wils. Winter.

Red-ireasted Sandpiper, Tıluga rufa, “ Spring.

Truga istardica, Bonap Syn.

Tringa cincrea, Sw \& Rich

Knot or Ash-colored Sandpper, Nutt. Man.

Kuot or Ash-colored Saudprier, 'Trisga islandica, Aud.

Specific Character-Bill straight. longer than the head; tarsi one inch and three-sixteenths long; rump and upper tail coverts white, barred with dark brown; region of the rent and the lower tail coverts white with dusky markings. In spring the upper parts are ash gray, variegated with black and pale yellowish-red; lower parts including the throat and fore neck brownish-orange. In autumn the upper parts are ash-gray, margined with dull white; rump and upper tail coverts barred with black and whie; lower parts white; the sides of the body marked with dusky; a dull white line over the eye. Adult in spring-bill black; a broad band of reddish brown commences at the base of the upper mandible, extends half way to the eye, where it changes to reddish-brown; upper part of head and the hind neck dusky, the feathers margined with grayish white; a few touches of pale reddish-brown on the latter; throat, fore neck, breast, and abdomen reddish-brown; vent white; lower tail coverts white, spotted with dusky; upper plumage blackish brown; upper tail-coverts barred with black and white; tail pale 
brown, margined with white; primary coverts black, tipped with white; secondary coverts grayish-brown, margined with white. Young with the upper parts grayish-brown, the feathers with central dusky streaks, a narrow line of cinnamon color toward their margins, which are dull white; the lower parts ash-gray. Length of adult ten inches, wing six and three quarters.

This species is familiar to our gunners by the name of Robin Snipe. In the great South Bay, Long Island, where those immense salt marshes are separated by creeks and channels, a number of beautiful Islands appear, differing in size and form, each having an appropriate name; they form quite an interesting feature in the geography of the Island; there the Red-breasted Sandpiper, during its short stay in the spring takes up its abode. Shortly after daylight it commences its daily labor in search of food, visiting the shoal ponds that abound with small shell fish, on which they chiefly subsist. The wily gunner, eager to profit by the ready sale of this superior bird, makes early preparation to receive them; lying concealed near their favorite haunts, by imitating their peculiar note, he thins their ranks by bringing them within reach of his well directed gun.

At the period for migrating this species assemble in flocks and steer for the North, where it passes the season of reproduction; about the middle of August it returns with its young, when the change of plumage is quite visible-the abdomen at this time is white, the breast pale rufous. Late in September it moves southward; at this period the lower plumage is white, spotted on the neck, breast, and flanks with dusky; the upper plumage ash-gray; in this dress it is the "White Robin Snipe" of our gunners.

In the autumn it generally frequents the inner beach, and is sometimes observed along the surf, collecting minute marine productions that are cast on the shore by the waves. In the Fall it is more timid than it is in the spring, frequently passing within hearing of the fowler's treacherous whistle, without approaching his decoy. In the spring its lower plumage resembles the Red-breasted Thrush or Robin, (Turdus migratorius,) from which it receives its name. Common to both continents, and is said to lay four eggs. 


\section{'TRINGA BARTRAMIAN-WILSON.}

\section{BARTRAM'S SANDPIPER.}

Bartram Sandpiper, T'ringa Bartramia, Wils. Amer. Orn.

Totanus Bartramius, Bowap. Syn.

Totanus Bartramius, Bartram Tatler, Sw. \& Rich.

Bartramian Tatler, Nutt. Man.

Burtramian Sandpiper. Totanus Bartramius, Aud. Orn. Biog.

Specific Character-Bill slcnder, rather longer than the head; tarsi one inch and seven-eighths; neck rather long, slender; axillars distinctly barred with black and grayish-white; upper parts dark brown, margined with yellowish-brown; fore neck and fore part of the breast with arrow-shaped markings; rest of the lower parts yellowish-white. Adult with the bill slender, yeilowishgreen, dusky at the tip ; upper part of the head dark brown, with a central yellowish-brown line, the frather's margined with the same color; hind part and sides of the neck yellowish-brown, streaked with dusky ; fore part of the neck and breast pales, with pointed streaks of dusky; sides of the body barred with the same; rest of lower parts yellowish-white; lower wing coverts white, barred with brownish-black; upper plumage dark brown, margined with yellowish brown, darker on the hind part of the back; primaries dark brown, coverts the same color ; inner webs of the primaries barred with white, more parlicularly on the first-the shaft of which is white; the rest brown, all tipped witlı white; secondaries more broadly tipped with the same; coverts and scapulars dark brown, margined with yellowish-brown and tipped with white; tail barred with black and yellowish brown, tipped with white; middle feathers darker, tipped with black. Length ten inches and half, wing six and five eighths.

About the middle of August I found this species very plentiful on the Shinnecock hills and on Montauk, especially on the latterwhere I met with it soon after leaving Nepeague Beach, and was not out of hearing of its wild note until I arrived at the extreme point. From the nature of those districts, which are hilly, it is more successfully pursued by the sportsman when on foot, than when hunting over a more level country, as he can better 


\section{( 227 )}

advance within shooting distance, without being observed by the game of which he is in pursuit; or, by stationing himself in the hollows, he will have frequent opportunities to shoot at them, as they pass from hill to hill. 'The eustomary mode of pursuing these birds is with a vehicle. In this manner they do not appear to be so early advised of the evil intention of the gunner. By this means they are more readily approached; and by most gumers it is considered hopcless to pursuc them other than by riding. But this method is not only less exciting, but quite dangerous. The true sportsman prefers the nore exhilarating amusement, as well as more sportsmanlike manner, of walking, or, as occasion may require, creeping over the ground; and feels more highly gratified with bagging half a clozen of these exceedingly wild and superior birds, than with boasting over a grcater number, obtained by shooting from an open carriage.

In order to meet with success when pursuing them on foot, it is necessary to be acquainted with their habits; it also requires a good marksman and a quick shot.

This favorite species was found breeding by my friend Philip Brasher, in the neighborhood of Rock River, Illinois. S. F. Baird, Esq., residing at Carlisle, Pennsylvania, informs me that it breeds in that section.

In Massachusctts, Rhode Island, New Jersey, and on the Shinnecock and Hempstead Plains, Long Island, it is common, where it is known by the name of "Gray," "Griss," "Field," or "Upland Plover." It is very wary, and difficult to be approached. On the ground, it has an erect and graceful gait. When alarmed, ii runs rapidly for a short distance before taking wing, uttering a whistling note as it rises; its flight is rapid, frequently going out of sight before alighting. It usually keeps on the open dry grounds --feeding on grasshoppers, insects, and seeds. In the month of August it is generally in fine condition, and highly prized as game.

When feeding, for greater security, this species scatter about; the instant the alarm is given, all move off.

In the latter part of August it migrates southward, and it is said performs the journey at night. Stragglers frequently remain behind until quite late in September. 


\title{
TRINGA ALPINA-LINN.
}

\author{
RED-BACKED SANDPIPER.
}

\author{
Tringa alpina, Red-backed Sandpiper, Wils. \\ Tringa alpina. Bonap. Syn. \\ Tringa alpina, Americaz Dunlin, Sw. \& Rich. \\ Dunlin or Oxbird, Nutt. Man. \\ Red-backed Sandpiper, Tringa alpina, And.
}

Specific Character-Bill about one third longer than the head, bent toward the end; length of tarsi one inch. Adult with the bill black - one third longer than the head, slightly bent toward the end, and rather shorter than that of T. Subarquata; upper part of the head, back, and scapulars chestnut-red, the centre of each feather black, which color occupies a large portion of the scapulars; wing coverts and quills grayish-brown; the bases and tips of the secondaries, and part of the outer webs of the middle primaries, white; forehead, sides of the head, and hind neck, pale reddish-gray, streaked with dusky; fore neck and upper part of breast grayish white, streaked with dusky ; on the lower part of the breast a large black patch; abdomen white; lower tail coverts white, marked with dusky; tail light brownish-gray, streaked-the central feathers darker.

Winter dress, upper parts brownish-gray ; throat grayish-white ; fore part and sides of neck, sides of the head, and sides of the body, pale brownish-gray, faintly streaked with darker; rest of the lower parts white. Length seven inches and a half, wing four and an eighth.

This bird, more familiar to our gunners by the name of "Blackbreast," arrives on the shores of Long Island in the month of April. It soon passes on to the North, and is said to breed in the Arctic regions. In the month of September it returns, and at that season is quite abundant, though not so plentiful with us as it is on the sea coast of New Jersey. It associates in flocks, and frequents the shores, sand bars and muddy flats, feeding on worms and minute shell-fish, which abound in such places. In the month of October 


\section{(229)}

it is usually very fat, and is considered excellent eating. In autumn, the plumage is so entirely different from that of spring, that by gunners generally it is considered a distinct species, and is called by them at that season "Winter Snipe." It then resembles the autumnal dress of the Curlew Sandpiper, the form and length of their bills being not unlike. By persons not accustomed to comparing birds, the two species might easily be confounded. The neck of the latter is longer and more slender-the head smaller and more rounded-the wings and legs longer-and with its general superiority in size, is sufficient to determine the species.

The Red-backed Sandpiper is found during autumn on the sandy and muddy shores along the whole extent of the coast of the United States. It is a restless, active bird, and gleans its food with great nimbleness, and seems to be fond of continually changing its position. Soon after alighting, they collect together, and make a short excursion over the water, again alighting a short distance from where they had previously taken wing. During their ærial excursions, when whirling about, they crowd so close together, that many are killed at a single shot. On one of these occasions, Mr. Brasher informs me that he killed fifty-two, by discharging both barrels into a flock. This number is greater than I ever before heard of; but from ten to fifteen is not unusual.

To the curious who are fond of speculating on anomalies, I will mention a coincidence connected with an individual of this species, that $\mathrm{I}$ am at a loss to account for. In the month of Novernber, 1840 , a gentleman shot a Red-backed Sandpiper. Not recognising it in its winter dress, and supposing it to be something unusual, he had the politeness to forward it to my address. It being a very common species, and having in my cabinet several duplicates in both spring and winter plumage, I did not think it worth preserving. I threw it carelessly on my table, where it remained for two or three weeks without receiving further notice. At the expiration of that time, my attention was again called to it, when I was somewhat surprised to find it in as good condition as when I had first received it. It having been shot about three weeks, and during the time that it was in my possession kept in a room in which almost every 
day there was a fire, I decided, as a matter of curiosity, to keep it, in order to ascertain how long it would remain before decomposition would take place. On several subsequent examinations, I found no symptoms of decay, but discovered that the breast and other fleshy parts began to shrink. Now, at the expiration of two years, it is perfectly dry and hard-the eyes sunk in, or entirely dried up, a large portion of the breast-bone bare, the abdomen much contracted, and at the same time all the feathers are complete; in other words, it is a self-preserved mummy. The entrails were not remored, neither was it injected, nor artificial means of any kind resorted to. Had this occurred with an upland bird, especially when in poor condition, I should not have thought it strange; but the shore birds, from their being so excessively oily, are proverbial for spoiling soon after shooting.

\section{TRINGA RUFESCENS-VIEILL.}

\section{BUFF-BREASTED SANDPIPER.}

Tringa rufesccns, Nutt. Man.

Triugd rufescens, Aud. Orn. Biog.

Specific Character-Bill very slender, about the same length as the head; length of tarsi flfteen-sixteenths of an inch; primaries dark brown, the inner webs at base white, toward the end finely dotted with black, and margined with yellowish-red; sides of the head, neck all round, and the breast yellowish-red, spotted with brownish-black; rest of the lower parts paler. Adult with the head rather large; loral space, sides of the head, hind neck, fore neck, breast, and sides of the body, yellowish-red, spotted with dusky, throat rather paler; upper part of the head dusky, the feathers margined with reddish-white; the feathers on the fore part of the back dark brown, margined with white; the hind part of the back darker, margined with reddish-yellow; wings dark brown, outer secondaries narrowly tipped with white; coverts 


\section{(231)}

light brown, edged with pale yellowish-white ; abdomen whitisßs barred with buff; upper tail coverts dark brown, tipped with light. er brown; under tail coverts white; tail brown, margined and tipped with soiled white-two middle feathers darker and longest. Length eight inches, wing five and three-eighths.

With us, the Buff-breasted Sandpiper is not a very common bird, though its occurrence is by no means unusual. Almost cvery season a few are observed along the southern shores of Loner Island, and during autumn we occasionally find it in our marke's stripped of its feathers, and exposed for sale along with the Pectoral Sandpiper, from which it is casily distinguished by the shortness of its bill, which is more slender, as well as much shorter than that of T. Pectoralis.

In the month of August, 1841, Mr. Brasher met with a party of five, on the shore of Gowannus Bay, which number is larger than I have seen in one group. He informs me that they appeared very gentle, allowing him to advance within shooting distance without seeming to notice lis presence. At the first discharge of his gun, (which procured him three,( the surviving two made a slort flight over the water, returning in a few minutes to the shore, at a short distance from where they had previously taken wing, which gave him an opportunity of securing the whole number.

When flying from you, they appear not unlike the Pectoral Sandpiper, to which their upper plumage has some resemblance. 


\title{
TRINGA HIMANTOPUS-BONAP.
}

\author{
I,ONG-LEGGED SANDPIPER.
}

Tring a himantopus, Slender shank Sandpiper, Sw. \& Rich.

Long legged Sandpiper, Audubon's Stilt Sandpiper, Douglass Stitt Sanupiper, Nutt. Mar.

Long-legged Sandpiper, Tringa himantopus, Aud. Orn. Biog.

Specific Character-Bill about one third longer than the head, slightly arched; length of tarsi one inch and three-eighths, Adult with the upper parts brownish.black, the feathers margined with reddish-white; the edges of the scapulars with semiform markings of the same; rump and upper tail coverts white, transversely bar. red with dusky; tail light-gray, the feathers white at the base, and along the middle; primary quills and coverts brownish-black-in. ner tinged with gray; the shaft of the outer primary white; secondaries brownish-gray, margined with reddish-white, the inner dus. ky; a broad whitish line over the eye ; loral space dusky; auriculars pale brownish-red; fore part and sides of neck grayish-white, tinged with red, and longitudinally streaked with dusky; the rest of the lower parts pale reddish, transversely barred with dusky; the middle of the breast and the abdomen without markings; legs long and slender, of a yellowish-green color. In autumn, the plumage duller, of a more grayish appearance, and the reddish markings wanting, excepting on the sides of the head, and a few touches on the scapular. Length nine inches, wing five.

On Long Island, the Long-legged Sandpiper is not abundant. In all my excursions, I have only obtained two individuals, both of which proved to be males. These I shot on a large meadow lying in the South Bay known as "Cedar Island." The first I procured in the latter part of August, 1840-the other in the early part of September in the year following. In both instances they were in in company with a single Pectoral Sandpiper. The first I shot before it alighted, which deprived me of an opportunity of observing its manners; but I was delighted at securing a specimen of a species which I had long been desirous to obtain. The second 
alighted among my decoys while I was lying at a salt pond on the meadow. It walked about with an erect and graceful gait, occa. sionally stooping to probe the soft mud for worms and minute shell. fish, particles of which, on dissection, I found in its stomach. After spending a few minutes within reach of my gun, it becamc alarmed, uttered a shrill note, and took wing; while passing from me, I brought it down.

An experienced bay-man who was on the meadow at the time, informed me that in the course of many year's' shooting, he had met with a few stragglers, which he had always considered hybrids. In plumage it somewhat rescmbles the Red-breasted Snipe, but is much smaller, and by comparison it is easily detected.

"This species is not uneommon in the fur countries, up to the 60:h parallel, and perhaps still farther north."-Fauna Boreali Americana.

Mr. Audubon speaks of it as being common in the neighlorhood of the lower part of the Mississippi river, and he also met with it on Galveston Island, Texas; and from the circumstance of my having found it stripped of its feathers, and from six to eight on a string, cxposed for sale in the New York market, we may infer that occasionally a wandering flock visits the shores of Long Island.

\section{TRINGA PECTORALIS-BONAP.}

\section{PECTORAL SANDPIPER.}

Tringa pecloralis, Bonap. Sin.

Pectoral Sandpiper, Tringa pecloraits, Nutt. Man

Pectural Sandprper, Tringa pectoralis, Aud. Orm. Biog.

Specific Character-Bill straight, base orange-green; length of tarsi one inch and one-sixteenth; upper parts brownish-black edgred with reddish-broun; throat white; fore part of neck and upper part of the breast light brownish-gray, strealict with dusky ; rest of lower pus including the lower tail coverts white. Adult with the bill straight; top of the head dark brown, intermixed 
with black; sides of the head, neck and a large portion of the breast, grayish-brown, streaked with dusky ; chin white; a streak of dark brown before the eye, continuing to the nostril-directly above a faint line of white; back dark brown; feathers margined with white; primary quills dark brown-shaft of the first white; outer secondaries slightly edged with white; tail feathers brown, margined with brownish-white-two middle feathers darker, longest, and more pointed; lower part of the breast, abdomen, and sides of the body, and under tail coverts white; feet dull yellow; tibia bare, about half the length. Female, the general plumage lighter. Length nine inches and a half, wing five and a quarter.

During some seasons, this species is quite plentiful on the shores of Long Island. It is generally overlooked by the gunners, and I find that most of our sportsmen are not aware of the claims it has to their attention.

In the spring I have never met with it in large numbers, and from this circumstance I am inclined to the opinion that it passes on to its breeding grounds with but litile delay. In the latter part of August it returns, and increased numbers appear on the necks of land in the immediate vicinity of tide water, and are also found in the islands in the bay. Although large numbers are sometines seen occupying the same feeding grounds, still there appears to be a great want of sociability among them-each one seemingly so intent on providing for its own cornfort, as to be cntirely regardless of those of its companions.

$\mathrm{W}^{\gamma}$ hen feeding, the flock scatter over the bare places that occur on the moist grounds which they inhabit; and when thus employed, are silent. They are by no means wary, and regard the approach of the gunner with indifference. On one occasion, I fell in with a large number, the nearest one of which I walked up to within close shooting distance, seemingly entirely unnoticed. Notwithstanding there were upwards of forty in view, they were so widely distributed that I could not get two in a range, nor did I during my operations, which were continued until I had procured twenty-one of the number. At the report of my gun, those that were not sin. gled out, flew on a short distance, and resumed their occupation as 
before; and during the repeated firing, I did not observe an individual pass beyond the meadow which was comprised in a few acres. When surprised it springs up, presenting a fair mark; and, if allowed to proceed, flies steadily at a short distance above the surface of the ground.

It feeds on various species of insects and minute shell fish, which lie near the surface, and is at times seen boring with its bill to a greater depth. On dissection, I have found in its stomach particles of plants. Its note, which is a low whistle, is not often repeatel, except when apprehensive of danger.

To some of the residents of the Island, it is known by the name of "Meadow Snipe," and I have heard the bay-men term it "Shortneck." In autumn it is quite common at Egg Harbor, and sometimes remain there till the early part of November. Toward the latter part of the season it is in excellent flesh. On the sea-coast of New Jersey it is called "Fat Bird."

Mr. Baird has informed me that it occurs in Pennsylvania, in which section it has received the appellation of "Jack Snipe." I have occasionally seen it in our locality during the month of July; but in such instances it has been alone, and I have always at that period looked upon them as stragglers, who, from want of inclination or ability to perform the fatiguing journey, have loitered behind the migratory band.

On Long Island I do not think it breeds, and I am not aware that their nests have been found on the sea-coast of the United States. In autumn its flesh is very juicy and well flavored; when procured late in the season I think it superior to any of our shore birds; and I have partaken of it when I have thought it equal to any of our upland game. 


\title{
TRINGA MARITIMA-BRUNNICH.
}

\author{
PURPLE SANDPIPER.
}

Tringa maritima, Bonap. Syr.

Tringa inaritina, Purple Sandpiper, Sw. \& Rich.

Purple Saudpiper, Tringa maritima, Aud. Orn. Bıg.

Specific Character-Bill along the ridge one inch and three. eighths; length of tarsi nine-sixteenths of an inch; neck short, full; body compact; wings rather broad; the upper parts glossed with purple; fore neck, neck all round, grayish-brown; lower parts grayish-white, the breast and sides of the body marked with large purplish-brown spots. Adult with the bill orange at the base, black at the end; a spot of white before the eye; head and neck grayish brown, chin and upper part of the throat rather whiter; back blackish brown, deeply tinged with purple, the feathers fantly margined with white; breast grayish-brown, the foathers more broadly marked with white; lower part of the breast, abdomen, and sides of the body, grayish-white, marked with large spots of brown-under tail coverts the same; primaries dark brown, shafts white, blackishbrown at the tips; secondaries margined and tipped with whiteseveral of the middle ones white; tail feathers ash-gray, margined with white, excepting the middle ones, which are dark brown; feet light orange. Length nine inches and a half, wing five.

This species I have nerer met with, and from my own observations of its habits and customs I know nothing. On the shore of Long Island it is exceedingly rare. At this I am somewhat surprised, as it is sid to occur very plentifully on the sea coast of Massachusetts. Oí all the transient visiters, there is no species for which I have made more diligent search than the Purple Sandpiper. At different seasons of the year, I have traversed the beaches and shoals on the south, and rambled over the rocky shores of the north side of the Island-but thus far it has eluded all my endeavors. Respecting it, I have had frequent conversations with the bay-men, without gathering any information, it being to those with 
whom I have conversed entirely unknown; and were it not from having in my possession a specimen that was purchased in Fulton Market, and having seen two or three others that were procured through the same source-all of which, it is said, were shot on the eastern end of the Island-I would not feel at liberty to include it in our local Fauna.

According to Mr. Audubon, this species is very abundant in the United States, and nowhere more so than in the neighborhood of the harbor of Boston. When there, a gunner in his employ brought in several dozens, which he had lilled in the course of a single afternoon.

In speaking of its habits, he says that they are seen in floclss of eight or ten, on the rocky shores of the sex. 'They seem to shun sandy beaches, and seldom advance far inland; and Mr. A. adds, that south of New York they are rarely met with.

\section{'TRINGA SUBARQUATA-TEM.}

\section{CURLEW SANDPIPER.}

Tringa suharquata, Bozap. Svn.

Cape Curlew or Saudpiper, Nutt. Man.

Cuilew Satsdpiper, T'ring 1 susarquata. Aud. Orn. Biog.

Specific Character-Bill one inch and a half long, slightly arched; tarsi one inch and seven-eighths. Adult with the bill an inch and a half long, curred, dark olive green; a line of grayishwhite, intermixed with pale red, from the base of the upper mandible, passing over the eye ; upper part of the head darli brown, the feathers margined with pale red ; chin white; a spot of brown at the base of the bill, extending back to the eye; breast, sides of the head, neck, and sides of the body rufous. barred with white and dusky ; flanks whitish, barred with dusky; abdomen whitish, tinged with rufous; under tail coverts white, with a dusky spot near the tips ; upper tail coverts white, barred with dark brown; general upper plumage dark brown, the feathers largely spotted with reddish brown, and tipped with white; primaries dark brown, secondaries lighter, margined with white; coverts light brown, slightly margined with white. Winter plumage-chin white; a line of 
white from the bill passing over the eye, entire length of the head; upper plumage grayish-brown, streaked in the centre with black; fore neck and upper part of the breast, ash-gray, streaked with dusky ; lower part of the breast, abdomen, and lower tail coverts white; upper tail coverts white, spotted with dusky; wings brown, coverts lighter, tipped with white. Length eight inches and three quarters, wing five.

This species is an inhabitant of both continents. It has been found in France and Switzerland, and has been seen during the breeding season nesting along the water courses in Holland. We have no account of its breeding in America, and its occurrence within the limits of the Union is unfrequent; and from all that I can learn respecting its wanlerings, it has more frequently visited our section than any other portion of the sea coast of the United States. Mr. Bell informs me that he has in the course of several years purchased seven or eight in the Fulton Market, New York; and I know of two or three others obtained there. The cabinet of the N. Y. Lyceum of Natural History contains a superb specimen, and $I$ have in my possession a fine adult male in spring plumageand another in winter dress-all of which were procured on the ever productive shores of Long Island. Of its habits but little is known, further than that it frequents the shores, and searches for food much in the manner of many other species of 'l'ringa. Mr. Audubon remarks, that during his extensire rambles along our coasts, and in the interior, he has only seen three birds of this species, two of which were shot at Great Egg Habor in the spring of 1839-the other on Long Island, near Sandy Hook. Of this Genus he considers it the most rare of any species which inhabits North America. 


\title{
TRINGA SEMIPALMATA-WILSON.
}

\author{
SEMIPAIMATED SANDPIPER.
}

\author{
Semipalnated Sardepiper, Tringa Semipalmata, Wils. Amer. Orn. \\ Trunga Semipalmata, Bonap. Syn. \\ Semipalinated Sabdpiper, Nutt. Man. \\ Tringa Senipralmata, Aud. Orn. Bog.
}

Specific Character-Bill rather stout, broad toward the point; along the gap about one inch; length of tarsi seven-eighths of an inch; bill and legs black; tocs half webbed. Adult with the bill slender, about the length of the head-rlark green, nearly approaching to black; head, sides, and hind part of neck ash gray, streaked with dusky; upper parts blackish-brown, the feathers edged with grayish white; secondary coverts tipped with white; primary coverts brownish-black, as are the feathers on the rump; upper tail coverts the same; wing quills dusky, their shafts white; tail feathers ash gray, the inner webs of the middle pair much darker; over the eyc a white line; lower parts white; legs black. Length six incles and a half, wing four.

This numerous species inhabits almost every part of the North American continent. In large flocks, they congregate on the beaches and sand-bars, and meadows, along the sea coast, as well as on the shores of the interior lakes and streams. When feeding this species scatter about in small parties; when surprised, it runs with a peculiarly rapid movement-collecting together in such close bodies, that as many as twenty, and sometimes a larger number, are killed at a single discharge. When closely pursued, they move off in one mass, uttering a chirping note, which by imitating they shortly obey. They subsist chiefly on minute animal productions. On dissecting it $I$ have found in its stomach small particles of sea-weed and sand. In the fall it gets rery fat, and is considered a delicacy. It breeds at the far Ncrth, laying four or five white eggs, spotted and blotehed with black.

It arrives among us in spring, and remains with us, should the season be open, until quite late in autumn, when it departs for its winter quarters at the South. 


\title{
TRINGA PUSILLA-WILSON.
}

\section{WILSON'S SANDPIPER.}

\author{
Jittle Sandpiper, Tringa pusilla, Wils. Amer. Orn. \\ Tringa pus:lia, Bunap. Syu. \\ W'ilson's Sandpiper, 'Tringa Wilsonii, Nutt. Man. \\ Li.lle Sandpiper, 'Tinga pusilla, Aud. Orw. Bıog.
}

Specific Character-Bill along the gap three quarters of an inch, slender; tarsi three quarters of an inch; legs yellowish-green. Adult with the bill brownish-black; upper parts of the brfast gray brown, mixed with white; back and upper parts black; the wholc plumage above broadly edged with bright bay and yellow ochre ; primaries black-greater coverts the same, tipped with white; tail rounded, the four exterior feathers on each side dull white-the rest dark brown; tertials as long as the primaries; head above dark brown, with paler edges; over the eye a streak of whitish; belly and vent white. Length five inches and a half, wing three and a half. With many of our birds, we observe that individuals of the same species vary in length, extent, and sometimes differ slightly in their bills, even with those which have arrived at maturity.On consulting Ornithological works, we notice that there are no two writers, whose measurement is in all cases alike. With specimens of the Wilson's Sandpiper, we find in their proportions greator discrepancy than in many other species-and out of these differences we are inclined to the opinion that two spurious species have been created.

This-the smallest of our Sandpipers-is said to breed within the Arctic circle. It is a very common species, and though not so plentiful as the former, is distributed along the whole coast. They collect in large flocks, and resort to the great masses of drifting seaweed, and are also observed along the shores and sedgy borders of salt ponds, gleaning minute shell-fish and marine insects, in company with the Semipalmated Sandpiper. 
Though more abundant on the coast, it is not entirely confined to the sea shore, but is likewise met with along the margins of the interior lakes and rivers. On the shores of Long Island it is very plentiful, and during the month of September is usually in excellent condition for the table. By gunners generally, it is neglected on account of its inferior size; though by many it is esteemed far superior, both in flavor and juiciness, to many of our larger shore birds. This species has a low and lisping note; when alarmed, it moves off in a confused and irregular manner, uttering a shrill twitter. During the month of October, it migrates southward.

Early in spring it appears on the shores of New Jersey and Long Island, and like the Semipalmated Sandpiper, numbers are seen during the summer months; but in either locality their nests are not found, and I am not aware that they breed within the limits of the Union. On the coast of Labrador, during the breeding season, both species were observed by Mr. Audubon.

\section{TRINGA SCHINZII-BREHM.}

\section{SCHINZ'S SANDPIPER.}

Tringa Sclinzii, Bonap. Syn.

Tringa Schinzıi, Schinz's Sandpiper, Sw. \& Rich.

Schimz's Sandplper, Nutt. Man.

Schinz's Saudplper, Tringa Schinzii, Aud. Orn。 Biog。

Specific Character-Bill greenish-black, straight, rather slender, along the gap one inch; length of tarsi seven-eighths of an inch; upper parts brownish-black, edged with yellowish-gray and reddishbrown; fore part and sides of the neck and breast streaked and spotted with dusky; sides of the body barred with the same; rest of the lower parts white. Adult with the loral space dusky, a line above it white, spotted with dusky; upper part of the head brown, intermixed with dusky; chin white; throat, fore neck, and upper part of the breast streaked and spotted with dusky on white ground-the spots more perfect on the latter; sides of the head, neck, and the hind neck darker; general upper plumage brownish black, edged with yellowish-gray; the feathers on the back and 
scapulars marked with reddish-brown; primaries brown, shafts partially white, darker at the base and tips; secondary coverts plain brown, margined on the inner webs with white, tipped with the same; lower parts of the breast, abdomen, and under tail coverts, white; sides of the body barred with dusky; tail feathers light brown, margined on both inner and outer webs with white-two middle feethers darlier, longer, and more pointed; upper tail coverts white, spotted with dusky. Length seven inches and a half, wing four and three-eighths.

This species is said to inhabit both continents. It is met with along the whole extent of the coast of the United States.

IVith us, it does not appear to be a very plentiful species. I have never observed large flocks, though during my excursions, have frequently met with small parties, distributed along the margins of creeks and pools, feeding in company with the Semipalmater Sandpiper, from which it can at all times te distinguisher by its superior size. It is more watchful than that species, and at the report of a gun seems to take greater alarm, usually fiying to a farther distance. It seldom revisits the place from which it has been driven in company with its less timid companion, which, by the time the gunner has reloaded his piece, has returned to its feeding ground as unconcernedly as before its flight.

The Schinz Sandpiper is not entirely confined to the immediate vicinity of the sea. I have seen it along the shores of the Hudson River, in the vicinity of Poughkeepsie, and on the margins of ponds in the interior counties of this State I have shot it. When disturbed it moves quickly off, repeating a rather low note; but its voice is distinctly audible above that of the small Tringas with which it associates. 


\title{
CALIDRIS ARENARIA-ILLIGER.
}

\author{
SANDERLING.
}

\begin{abstract}
Ruddy Plover, Charadrics rubidus, Wils. Amer. Orn. Summer.
Sanderling Plover, Charadrius Caliclris, " Winter.

Calidris arenaria, Sandesling, Siv. \& Rich.

Sauderling Plover, Caladris arenaria, Nutt. Man.

Sanderlıng, Tringa arenaria, Aud. Orn. Biog.
\end{abstract}

Specific Character-Bill straight, black, along the gap one inch and one-eighth; length of tarsi one inch; hind toe wanting. Adult with the bill straight, about as long as the head. Spring plumage, upper parts, with the throat, fore neck, and upper part of the breast rufous, intermixed with dusky and grayish-white, deeper red on the back; lower part of the breast, abdomen, and sides of the boly pure white; tarsiand feet black; claws small, compressed; primaries, outer webs black, inner webs light brown; shafts brown at the base, tips black, rest parts white; secondaries light brown, broadly margined with white. Winter dress, lower parts white; upper parts grayish-white, intermixed with black or dusky, darkest on the back. Length seven inches and three quarters, wing four and seven-eighths.

The Sanderling is sa:d to be an inhabitant of both Europe and America. According to Latham, it is known to be an inluabitant of the remote coast of Australia, and is fourd on the shores of Lake Baikal in Siberia. T'o the coast of the United States it is one of the most common species, but with us I have never otserved very large numbers during spring. About the middle of August it arrives in flocks on the shores of Long. Island, and usually by the first of September is very abundant.

Sometimes it is seen occupying, with other small speciss of Sandpipers, the shoals and mud-flats that occur in the shal'ow pait of the bay, though generally it seems to prefer the more immedi- 
ate borders of the ocean. I have rarely, during the early part of autumn, visited the surf without meeting with large groups of Sanderlings collected along the beach, of which they have almost entire possession, as most of our shore birds find more productire feeding-grounds on the richer soil that is daily overflown by our inland bay.

The Sanderling is of a sociable disposition, and searches for food in company, and is observed probing the sand for small bivalve shells and marine worms-to which article of diet, however, it is not altogether confined, as at times it is seen attending the retiring wave, which furnishes it with shrimps and the like.

When feeding along the extreme verge of the ocean, it is pleas. ing to watch its active movements, when advancing or retreating with the influx or reflux of the sea. It is naturally very unwary, and regards man with less suspicion than most of our Tringas. When fired into, those whicin survive rise with a low whistling note, perform a few evolutions, and presently resume their occupation with as much confidence as previously exhibited. When wounded in the wing it takes to the water, and swims well.

Late in the season it gets very fat, and is excellent eating. The plumage of the Sanderling, like most other species, varies with the seasons. In spring, the fore part of the neck and upper portion of the breast, is of a pale rufous color; in autumn, the entire lower parts are pure white-exceeding in whiteness the bleached sand on which it dwells.

Early writers have classed this bird under the Genus Charadrius, (Plover,) to which the only claim it has, is, that the hind toe is wanting. Wilson, in his excellent work, speaks of the impropriety of this arrangement-though not wishing to disturb previous classification, has followed the same system as that adopted by his predecessors.

In our more modern nomenclature, it appears in a new Genus (Calidris) of Illiger, and up to the present day is the only species of that Genus discovered. In Mr. Audubon's work it is classed with the T'ringas, and with it we close our remarks on that Genus. 


\title{
GENUS PHALAROPE-BRISS.
}

\author{
PHALAROPE.
}

[Bill straight, slender, flattened toward the end, and about the length of the head, which is small; neck moderate; wings rather long and pointed; tail rounded; tarsi extremely compressed ; toes very slender, hird toe exceedingly small; anterior toes lobed, with a pectinated or comb-like membrane.]

\section{PHALAROPUS FULICARIUS-BONAP.}

\section{RED PHALAROPE.}

\section{Red Phalarope, Phalaropus hyperboreus, Wils. Amer. Orn. Phalaropus fulicarius, Plat-billed Phalarope, Sw. \& Rich. Red Phalarope, Nutt. Man. \\ Red Phalarope, Piralaropus fulicarius, Aud. Orn. Biog.}

Specific Character-Bill straight, flattened, rather deeply grooved from the nostrils nearly to the end, where it becomes abruptly narrow; length of tarsi three quarters of an inch. Adult with the forehead, throat, a line behind the eye, fore part of breast, abdomen, and lower tail coverts white; fore neck pale brown-a line beneath the eye, extending the whole length of the head, crown, fore part of back, tertials, wings, rump, upper tail coverts, and tail, blackish-brown-the feathers edged with dull yellowish; middle of back, and sides of the upper part of breast, grayish-blue-flanks streaked with the same; secondary coverts broadly tipped with white, forming a conspicuous band on the wings; bill black; legs and feet dull yellowish. This description is taken from a specimen shot in autuinn. In summer the bill is greenish-yellow; feet pale green; the whole lower parts deep orange-red. The form of the bill is at all times sufficient to distinguish this species. Length seven inches and a half, wing five.

This is another species with which our acquaintance is very limited. The specimen now before me was shot on the beach at "Quogue," and I have seen a few others that were precured in that vicinity. On the sea coast of New Jersey it is exceedingly rare, nor is it frequent in any portion of the Atlantic districts. It 
is an inhabitant of Europe, and is said to extend its migrations in spring to the northern parts of the continent, and to congregate on the borders of the Caspian Sea. We find it enumerated with the birds of the Fur countries, from which we extract this brief account. "This neat little bird abounds in high northern latitudesbreeds on the North Georgian Islands, and Melville Peninsula, and was often seen swimming on the sea far from land by the Northern Expedition. It inhabits during summer the hyperboreal regions of America, migrating to more temperate parts at the approach of winter, along the shores of the Pacific.,"

\section{GENUS LOBIPES-CUVIER.}

\section{LOBEFOOT.}

[General appearance delicate-bill exceedingly slender, taperiug, and rather longer than the head; head sinall, with the fore part rounded; neck moserate, rather slender; wings long, pointed; tail of moderate length, rounded-tarsi rather long, compressed; toes sleuder-hind toe very small; anterior toes lobed, and connecicd at the base with webs ]

\section{LOBIPES WILSONII-SABINE.}

\section{WILSON'S LOBEFOOT.}

Gray Phalarne, Phalaropus lobatus, Wils. Amer. Orn.

Phalaropus Wilsunii, Bonan. Syn.

Wilson's Phalarope, Phalıropus Wilsonii, Bonap.

Phalaropus Wilsonii, Wilson's Phalarope, Sw. \& Rich.

American Pibalarope, Nutt. Man.

Wilson's Phalarope, Phularopus Wilsonii, Aud. Orn. Biog.

Specific Character-Bill black, slender, one inch and a half along the gap; length of tarsi one inch and a quarter; upper parts brownish-gray; a broad black band behind the eye, passing dorn the sides of the neck, changing into chestnut-red, passing over the wings; lower parts white. Adult with the bill black, slender; throat white; fore neck tinged with reddish-brown; entire lower parts pure white; tail light brown, margined and tipped with 
white, of which color is a portion of the inner webs, excepting the central, which are plain brown, slightly edged with white; upper tail coverts pale brown, broadly margined and tipped with white; back light brown, the feathers tipped with white; primaries plain brown, the inner margined with white; secondaries and their coverts lighter, margined and tipped with white; scapulars bluish gray, marked with large spots of reddish-brown-fore part of the back the same; a band of black commencing anterior to the eye, passing down the sides of the neck, changing into deep reddish brown as it falls over the shoulders; upper part of the head bluish gray, with a broad band of white on the nape; tarsi and feet black. Length ten inches, wing five and a quarter.

In the United States, the occurrence of this bird is so exceedingly rare, that but little is known respecting its habits. At Egg Harbor, as well as on Long Island, I have known few to occur. In very small numbers, Mr. Audubon has met with it in rarious parts of the Union. During the time of Wilson's collecting, he met with but a single individual; and since the death of that eminent Ornithologist, it has, in tribute of respect, been dedicated to his memory. "This elegant Pharalope breeds on the Saskatchewan, but was not seen by us beyond the fifty-fifth parallel, nor on the coast of Hudson's Bay. It is not uncommon on the borders of the lakes adjoining the city of Mexico, from whence Mr. Swainson has received both young and adult specimens." - Fauna Boreati Americana.

From all that we can gather respecting it, it seems to frequent similar situations, and feeds much in the manner of our Sandpipers. It is at all times rendered conspicuous by its peculiar markings, delicate form, and neat attire. 


\section{LOBIPES HYPERBOREUS-LATHAM.}

\section{HYPERBOREAN LOBEFOOT.}

Lobipes hyperboreus, I,atham.

Phaluropus byperboieus, Bouap. Syn.

Hyperborean I'halarope, Nutt. Man.

Hyperborean Phalarope, Phalaropus hyperboreus, Aud.

Specific Character-Bill black, very slender; when measured along the gap, one inch; lengih of tarsi three quarters. Adult with the throat white; head bluish-gray, lighter on the nape and fore part of the back; on the sides of the neck a broad band of pale reddish-brown, nearly meeting on the fore and lind neck; sides of the lower neck and sides of the breast bluish-gray; lower parts pure white ; tail brown, the feathers darlier in the centre, and tipped with white; upper tail coverts bluish-gray, tipped with white - hind part of the back the same; primaries brown, their shafts white, the tips blackish-brown; secondaries rather lighter brown, their outer webs margined with white, their coverts dark brown, tipped with white-the scapulars margined on their outer webs with pale reddish-brown.

Winter dress- - he forehead white; upper part of the head blackish gray, with a rather light band on the nape; a spot of dusky on the side of the head behind the eye; throat white; the upper part and sides of the neck grayish-white; lower neck and sides of the breast dusky-white-rest of the lower parts white, with a few spots of dusky on the flanks; tail grayish-brown, margined with white, tipped with yellowish-white; primaries dusky, the inner margined internally with white; a broad band of white on the wings, formed by the tips of the secondaries; secondaries and scapulars blackish brown, margined with dull yellowish-brown. Length eight inches, wing four and three-eighths.

Of this Phalarope I have seen a few specimens that were procured on the coast of New Jersey, where, as with us, it is seldom observed. The last individual that I met with, I came upon while engaged in shooting Terns on the inner beach, in the latter part of June. I observed it at a distance in company with a 
party of small Sandpipers, which I was scrutinizing through a glass that always accompanies me in my collecting tours. $\Lambda$ ppearing longer than its assoeiates, and too small for the Yellow-shauks, or other familiar species of which we have spoken, I immediately set about ascertaining to what speeies it belonged-and as I advane. ed, was much pleased to find that an opportunity offered to secure another specimen of one of the rarest of our birds. It was very gentle, and seemed to have no disposition to take wing, although I had arrived quite near. It was standing in a shallow pool of water, and during my observations remained in a listless attitude, scarce. ly changing its position until alarmed by the explosion of the cap of the first barrel of my gun, which missed fire-when it sprung up, uttering a low whistling note; and while passing slowly from me, with the other barrel I secured it. On dissection it proved to be a male, and from its plumage I considered it the young of the year. In its stomach I found particles of shells and sand.

In the middle districts it is not frequent, and is rarely seen south of New York. According to Mr. Audubon it is more common on the eastern coast, more particularly so on that of the State of Maine. It usually alights on the water, and is at times seen swimming far at sea.

Dr. Richardson informs us that it breeds in all the Arctic coasts of America, and resorts to the shores of Hudson's Bay in the autumn. It lays two or three yellowish-olive eggs, closely spotted with brown.

On referring to my notes, I find the following communication from my obliging friend, S. F. Baird:

"DEar $S_{1 R}$-I think that you will be somewhat surprised to hear of the Hyperborean Phalarope occurring here A relative of mine told me, immediately on my return from Washington, that he had shot a Sandpiper with lobed feet, and a black stripe on the sides of the head-which, however, he had lost. I supposed it to be a Semipalmated Sandpiper, until about a week after, when he came in with a beautiful speeimen of this Phalarope, which he shot while it was swimming among some ducks. It was a young male, which he informs me is similar to the specimen he shot during my absence from Carlisle. A week or two since, we also obtained a Semipal. mated Sandpiper, the first that we have observed. Yours truly, .

"Carlisle, Pa., Oct. 10, 1842.

S. F. BAIRD." 


\section{GENUS TOTANUS-BECHST.}

\section{TATLER.}

[Bill longer than the head, straight, hard, slender; head moderate; neck slender, rather long; body rather leng; wings lo:ng, pointed; tail shortrounded; tibia bure, rounded about half its lergth ; legs long, compressedtoes rather long - hind toe very small-antcrior toes comected at the base by webs, the inner slightly webbed.]

\section{TOTANUS FLAVIPES-LATHAM.}

\section{YELLOW-SHANKS TATLER.}

\section{Scolopax flavipes, Wils. Amer. Orn.}

Totanus flavipes, Bonap Syn.

Totanns favipes, Yellow-shanks Tatier, Sw. \& Rich.

Ycllow-shanks, Totanus flavipes, Aud. Orn. Biog.

Specific Character-Bill along the ridge one inch and threeeighths; length of tarsi one inch and seven-eighths; legs yellow. Adult with the bill black; throat white; upper part of the head, lores, cheeks, hind part and sides of the neck, deep brownish-gray, streaked with grayish-white; eye encircled with white, a band of the same color from the bill to the eye; fore neck, sides of the body, and upper part of the breast, grayish-white, streaked with grayish-brown; lower part of the breast and abdomen white; lower tail coverts white, theouter feathers barred with brown; scapulars and fore part of the back brown, the feathers barred and spotted with black and white; primaries blackish-brown, the shaft of the outer brownish white, whiter toward the tip-the rest dark brown; secondaries margined with white; hind part of the back brownish-gray; tail barred with grayish-brown, white at the tip; legs, feet, and toes yellow; claws black. Length ten inches and three quarters, wing six. Young with the legs greenish-and by those who have not recognized it as the young of the year, I have heard the propriêty of its name questioned. 
This common species, well known throughout the Union, arrives on the shores of New Jersey and Long Island in the early part of May. It associates in flocks, and frequents the muddy flats that are left bare at the recess of the tide. At high water, it resorts to the ponds on the beaches and meadows, where it gleans its food, consisting of small shell-fish, worms, and insects. It is sometimes observed wading into the shallow water, in pursuit of small fishes.

Gregarious in its habits, it is continually calling for others to unite with it, when its shrill cry informs the gunner of its approach. It obeys the decoys, answers the forwler's whistle, and if the sportsmon is well concealed, sets its wings, and glides smoothly up to the decoys, gradually lowering its long legs-which, when flying, appear conspicnous beyond the tail feathers-and gently alights on the soft mud, or in the shallow water. It is more timid than the Red-breasted Snipe; but like that species, when invited by the gunner's whistle, it is not unusual for it to return, and receive the second fire.

The roice of the Yellow-shanks is shrill, and consists of three or more notes. When wounded in the wing, it runs fist, and hides among the grass, frequently so well concealing itself as to avoid detection. IIs manners and customs are well known to our gunners, and it is met with by sportsmen on many streams in the interior.Although its flesh is not superior, it meets with ready sale in the New York markets, and large numbers are shot to supply the demand.

A noted gunner residing in the vicinity of Bellport, informed me that he killet one hundred and six Yellow-shanks, by discharging both barrels of his gun into a flock while they were sitting along the beach. This is a higher number than I should have hit upon, had I been asked to venture an opinion on the result of a very unusually successful shot. Still, it is entitled to credit. Wilson spealis of eighty-five Red-roreasted Snipe having been shot at one discharge of a musket. Mr. Audubon mentions that he was present when one hundred and twenty-seven were killed by discharging three barrels. Mr. Brasher, during the month of Nay of last year, at Egg Harbor, killed thirty-three Red-breasted Sniçe by discharging 
both barrels into a flock as they were passing by him. This num. ber, although small in comparison with those mentioned above, is large, and exceeds any exploit of my own, either with the present or former species - of both of which I have killed a goodly num. ber, but do not deem it important to tax my menory with the number shot on any one occasion, to further illustrate the gregarious habits of this familiar bird.

In the Fauna Boreali Americana, it is stated that the Yellowshanks is a very common bird in the fur countries, and is seen either solitary or in pairs, on the banlis of every river, lake, and marsh, up to the northern extremity of the continent.

Mr. Audubon found a few on the coast of Labrador, but did not discover their nests-and adds that he has been informed that they breed in considerable numbers about Picton. In the latter part of August, the Yellow-shank commences moving southward, and in September they have usually all retired from the shores of Long Island.

\section{TOTANUS VOCIFERUS-WILSON.}

\section{TELL-TALE TATLER.}

Tell-tale Godwit or Snipe, Scolopax vociferus, Wils. Amer. Orn.

Totanus melanoleucus. Bonap. Syn.

Totanus vociferus, 'Tell-tale, Sw. \& Rich.

Tell-tale or Greater Yellow-shanks, Nutt. Man.

Tell-tale Godwit, Totanus melanoleucus, Aud. Orn. Biog.

Specific Character-Bill along the ridge $2 \frac{1}{1}$ inches; tarsi $2 \frac{1}{2}$; legs yellow. Adult with the bill black, at the base bluish; upper part of the head, loral space, cheeks, and neck, streaked with brownish-black and white; throat white; a white line from the bill to the eye; a white ring round the eye; breast and abdomen white, spotted and barred with brownish-black; sides and tail coverts the same; lower surface of the primaries light gray-upper brownish black, the inner spotted white; wing coverts and back, brown, spotted with white, and dusky; scapulars the same; tail brown, barred with white. 
Winter plumage, the upper parts lighter-larger portion of the breast and abdomen white; sides of the body barred with dusky. Length fourteen inches, wing seven and a quarter.

This species-with us not as numerous as the former-is known to the gunners by the name of Greater Yellow-shanks. It arrives on Long Island about two weeks earlier than the preceding, like which, its visit in the spring is of short duration. It has an attachment for the muddy shores of creeks and ponds-where it collects its food, and like many other species of shore birds, seems to have a fondness for the spawn of the King-crab or "Horse-foot." It goes to the North and returns in the latter part of August, and remains until cold weather. On the meadows, in the vicinity of Oyster Pond, I have shot them late in November. In autumn they get in fine condition, and their flesh is at that season well flavored. They do not usually associate in large flocks, generally roving about in parties of from five to twelve. Its voice is much stronger than that of the former, and consists of fewer notes, which by imitating, it obeys. It is more suspicious than the Lesser Yellowshanks, though if the gunner lies close, it approaches the decoys without much hesitation.

It walks over its feeding grounds with a graceful carriage, and collects its food in an elegant and easy manner. It is capable of rapid flight, and at times mounts high in the air, from which elevation its loud, clear, and familiar notes are often heard.

Its habits are similar to the preceding, to which it bears a great resemblance in markings. On the coast of New Jersey it is common, and I have been informed that a few breed there. On Long Island I can find no trace of its having been found breeding, and I have no recollection of meeting with it there during the month of June, or early part of July ; in the latter part of the last named month I have met with it, but that period is unusually early, as it generally returns to us from the North, from two to three weeks later than the Lesser Yellow-shanks. 


\title{
TOTANUS SEMIPALMATUS-LATH.
}

\section{SE.MIPALMATED TATLER.}

\author{
Scolopax semipalmata, Wils. \\ Totanus semip,alınatus, Srmipalmated Tatler, Sw. \& Rich. \\ Semipraluated Surpe or Willer, Nuit. \\ Semipalmaled Sripe or Willel, Aud.
}

Specific Character-Secondaries and basal part of the primaries white; toes connected at base by broad membranes. Adult with the head and neck brown, intermixed with grayish-white; breast and sides of the body spotted and waved with brown on white ground; abdomen white; tail coverts white, barred with brown; tail grayish brown, harred wih darker brown--ihe outer two feathers lighter; rump brown ; fore part of the back and wing coverts brown, largely spotted will dull white; primaries blackish brown, broadly banded with white; secondaries white. Length fifteen inclies and a half, wing cight.

This handsome species is well known to all our bay-men by the name of "Willet," by which appellation it is equally familiar to all sportsmen who fincy bay shooting.

It passes the winter in the Southern States, and at the approach of spring commences migrating northward. It arrives on the shores of Long Island about the tirst of May, and is common on the sea coast of New Jersey at the same period. It is quite common to the Island, though it cannot be said to be very abundant, nor is it so plentiful as it is at Egg Harbor, where it breeds. In the latter part of May its nest is found on the salt marshes among the grass, of which material, and a ferv rushes, it is formed. 'T'he eggs-four in number, are rather more than two inches in length, and about an inch and a half in breadtl, and very thick at the largest end-ihe color ciark olixe, blotched with blackish-brown, which markings are more numerous at the great end.

During the season of incubation, if you approach its nest, it rises from the marsh and flics wildly around, filling the air with its shril! cries, which consist of three notes, which are so violently repeated when defending its eggs or young, as to be audible half a mile distant. I have heard the gunners assert that on such occa- 
sions they have distinctly heard its vehement vociferations at a still greater distance.

During the breeding season, if not disturbed, it passes that anxious interval in silence; but at all other times is noted for its noisy outcry.

The fight of the Willet is swift, and performed with ease and grace. In general it inhabits the salt marshes-though when making excursions about the bays and inlets, it at low water alights on the naked shoals; and is at times seen wading breast deep in the water, pluming and dressing its feathers. It is exceedingly watchful, and when in exposer situations, however cautiously. the gunner may approach, it seldom allows him to arrive within shooting distance.

The address of the most experienced is seldom equal to its vigilance. The decoys offer a more favorable opportunity to procure it; but even in this manner it is by no means easily allured-notwithstanding the gunner is well hidden, and his ingeniously executed counterfeits rendered more deceptive by the perfect imitation he gives of its peculiar cry, which is promptly ansivered by the advaneing Willet, whose keen cye timely detecting the deception, it provokes the fowler by quickly changing its course, and darting off like an arrow, usually ascending as it passes on.

The Willet seldom associates with others of its tribe, though oceasionally stragglers are seen on the muddy shores, feeding in company with the Gulls and Sanderlings.

I am not aware that its nest has been observed on Long Island, though it is said to breed in several of the Middle States, and accorrling to Mr. Nuttall, it has been found in the vicinity of New Bedford. When flying, it is rendered very eonspicuous by the prominent markings on the wings. It feeds chiefly on worms, aquatic insects, small crabs, and minute shell-fish. When in good condition its flesh is quite palatable, but not esteemed so great a delicacy as its eggs.

Many of those birds that frequent the marshes are annoyed by insects which intrude themselves under the feathers-particularly under the wings. The Willet seems to be a favorite bird for those tormentors to quarter upon-so much so, that I have frequently supposed that I had performed an act of kindness by shooting it. 


\title{
TOTANUS SOLITARIUS-WILSON.
}

\author{
SOJITARY TATLER. \\ Solitary Sandpiper, Tringa solitaria, Wils. Amer. Orn. \\ Totanus chloropygius, Bonap. Syn. \\ Totauus chloropygius. Green-rump Taller, Sw. \& Rich. \\ Green-rump Tatler, Totanus chloropygius, Aud. Orı. Biog.
}

Specific Character-Bill greenish-black, slender, when measured along the gap one inch and a quarter; length of tarsi one and an eighth; upper parts deep greenish-brown, with a few small spots of white; fore neck grayish-brown; rest of the lower paris white. Adult with the bill slender, longer than the head, greenish ; tarsi and feet lighter green; chin white; a line of dull white from the base of the upper mandible passing over the eye; upper part of the head, hind neck, and a portion of the breast, grayish-white, streaked with dusky; fore neck, sides of the head and neck lighter; upper plumage greenish brown, the feathers tipped with white, giving it a spotted appearance on the back; tail and upper tail coverts barred with black and white; under tail coverts white-a few spots of dusky on the outer feathers; wings long, curved; primaries brownish-black; corerts greenish-brown; body slender; toes long and slender, outer connected by a membrane half way to the first joint; lower part of the breast and abdomen pure white; legs rather long. Length eight inches and a half, wing five and oneeighth.

This species, at different seasons, locates in various parts of the United States, and is said to advance up to the remote northern woody regions of the Fur countries. On Long Island it is not very abundant, yet by no means rare. Singly or in pairs, it is distributed along the creeks that are affected by the tide, and it is observed about the pools and rivulets more distant from the sea.

It but seldom visits the beach, and is rarely met with on the salt marshes in the bay. It takes up its abode near the habitation of man, preferring his society to that of the numerous species of T'ringa that flock on the shores. Not being considered game by sports- 
men, the Solitary Tatler becomes quite familiar. When nearly approached, it flies but a short distance before it again alights and resumes its occupation of probing the soft mud for worms and minute shell-fish, which abound within its favorite haunts. It also resorts to the decayed logs for the purpose of procuring grubs, and from this trait in its habits it has by some received the appellation of Wood Tatler. When surprised; it utters a sharp, whistling noteraises its wings-and runs nimbly over the miry ground; if closely pursued, it retreats to the opposite side of the pond; arranges its feathers, and shortly resumes its usual calm and gentle manner.

On the wing it is very active, and is sometimes seen darting after winged insects, which it is expert in catching; and when flying, its long and gracefully curved wings add much to the beauty of this neatly attired bird.

It arrives among us early in May, and takes its departure in September, wintering in the southern parts of the Union.

\section{TOTANUS MACULARIUS-WILSON.}

\section{SPOTTED TATLER.}

Tringa macularia, Wils. Amer. Orn.

Totanus macularius, Bonap. Syn.

Spotted Tatler or Peet-wect, Nutt. Man.

Spotted Sandpiper, Totanus macularius, Aud. Orn. Biog.

Specific Character-Bill along the gap about one inch; length of tarsi seven-eighths; upper parts brown, barred with dusky; lower parts white, spotted with blackish brown. Adult with the bill longer than the head, slender, greenish-yellow at the basedusky at the end; lower parts white, distinctly spotted with blackish brown; tail olive brown, faintly barred with dusky, and tipped with white; upper parts brown, barred with dusky; inner primaries tipped with white; secondaries more broadly tipped with the same; a band of white behind the eye-a white ring round the eye; outer toes connected by a membrane as far as the first joint. Length eight inches, wing three and seven-eighths. Young without the spots on the lower parts: 
This small and well-marked species is the first of this family that visits us in the spring. It appears on Long Island about the middle of April, and resides with us permahently until late in autumn, continuing its sojourn after most of the other species of T'ringa have departed for their winter quarters.

It is distributed throughout the United States, and occurs at Labrador, where, according to Mr. Audubon, as with us, it breeds, as well as along the coast of the Middle and Eastern States and the interior. It is a very common species, and from its habit of constantly raising and lowering its tail, it is familiar to persons residing in the country by the cognomen of "T'peter," or "Tiltup."

They do not associate in large flocks, and like the former, are rather solitary. They inhabit the moist grounds in the vicinity of streams and ponds, and often resort to the ploughed fields to glean up the worms that lie exposed in the furrows. Early in the month of May, it commences preparing its nest, and retires to a neighboring field for that purpose. The tenement-which is formed of dry grass and straw-is placed on the ground in a cluster of weeds or briars; sometimes it is found in the most exposed part of the pasture ground, only partially hidden by the stinted vegetation by which it is surrounded. It is also found along the banks of small streams, and on the margins of ponds. The eggs, four in number, are of a pale yellowish cast, irregularly spotted with blackish-brown. The young, soon after being hatched, runs among the grass, uttering a low, feeble, whispering note, which soon increases in cadence, so ds to be undistinguishable from the full and clear voice of its parentsand at that early period it is seen giving that peculiar movement to the tail feathers for which this species is noted. The flight of the Spotted Tatler is very uneven, seldom being seen flying in a straight line to any distance, and usually performs its ærial gambols at a short distance above the surface. When wounded in the wing, it takes to the brook, and swims under water with considerable swiftness. In pairs, or small parties, it talies possession of the muddy margins of all our water courses, from which they make excursions to the adjoining fields, sometimes alighting on the fence-rails, \&c.

Being exclusive in its habits, it never courts the society of other species, though it is not unfrequent that we see the intrusive Semipalmated Sondpiper shoring with it the nrodur of its feeding greunds. 


\section{GENUS LIMOSA-BRISS.}

GODWIT.

[Bill very long, a little recurved from the middle-rather slender, thicker at the base-lower mandible shorter; head moderate; neck rather long; wings long, very acute; tail short, even; legs long; toes four, rather slender-hind toe small-middle toe longest-anterior toes connected at the base by webs, the outer web much larger.]

\section{LIMOSA FEDOA-LINN.}

\section{GREAT MARBLED GODWIT.}

Great Marbled Godwit, Scolopax Fedoa, Wils.

Limosa Fedoa, Bonap. Syn.

Limosa Fedoa, Great Marbled Godwit, Sw. \& Rich.

Great Marbled Godwit, Nutt. Man.

Great Marbled Godwit, Limosa Fedoa, Aud.

Specific Character-Bill at base yellow, toward the end blackish brown; upper parts spotted and barred with yellowish-gray and brownish-black; lower parts pale reddish-brown; tail darker, barred with black. Adult male with the bill at the base yellow. ish brown, toward the end black; head and neck grayish-brown, tinged with pale reddish, streaked with dusky-darker on the up. per part of the head and hind neck; throat whitish; lower parts pale reddish-brown; under tail coverts barred with brown; tail reddish-brown, barred with dusky; upper tail coverts the same; upper parts barred with brownish-black and pale reddish-brown, spotted with dusky; inner primaries tipped with yellowish white; scapulars and wing coverts barred with pale reddish-brown and grayish-white; shaft of the first primary white, dusky at the tip ; inner shafts at the base white, rest part light brown, excepting the tips, which are dusky. Length sixteen inches, wing nine and a half. Female larger, exceeding the male from three to four inches. 
The Great Marbled Godwit, or "Marlin," as our gunners term it, arrives on the shores of Long Island in the month of May: it cannot be said to be an abundant species-still, we observe it visits us regularly every spring and autumn.

It associates in flocks, and usually passes its time on the shoals and salt marshes; it is exceedingly watchful, and will not allow of near approach-but when any of their numbers are wounded, their associates hover round them, uttering loud and shrill cries. On such occasions they crowd together, offering an excellent opportunity for the gunner to secure them. I have shot it from various points in the South Bay, but have met with far better success on "Pelican Bar," which at low water is a favorable place for procuring many other species of marine birds. The flesh of the Marlin is tender and juicy, and is prized as game.

\section{LIMOSA HUDSONICA-LATHAM.}

\section{HUDSONIAN GODWIT.}

Limosa Hudsonica, Hudsonian Godwit, Sw. \& Rich.

Hudsonian Godwit, Nutt. Man.

Hudsonian Godwit, Limosa Hudsonica, Aud. Orn. Biog.

Specific Character-Bill blackish-brown, at base of lower mandible yellow; upper parts light brown, marked with dull brown, and a few small white spots; neck all round brownish-gray; lower parts white, largely marked with ferruginous; basal part of tail feathers, and a band crossing the rump, white. Adult with the bill slender, blackish toward the tip, lighter at the base, particularly at the base of the lower mandible; a line of brownish-white from the bill to the eye; lower eyelid white; throat white, spotted with rust color ; head and neck brownish-gray ; lower parts white, marked with large spots of ferruginous; under tail coverts barred with brownish-black and ferruginous; tail brownish-black, with a white band at the base; a band over the rump; tips of primary coverts and bases of quills white; upper tail coverts brownish-black-their bases white; upper parts grayish-brown, scapulars marked with 
darker ; feet bluish. Length fifteen inches and a half, wing eight and a half. Young with the lower parts brownish-gray, the ferruginous markings wanting.

This bird with us is not as plentiful as the former, and is known to the gunners by the name of "Ring-tailed Marlin," - so called from the white band crossing the tail feathers. A few are shot every season on the shores of Long Island, and are occasionally procured on the sea coast of the Eastern States. Though not abundant in the middle districts, it is by no means a rare species. It is said to breed abundantly on the barren grounds near the Arctic seas, from whence it migrates through the interior, or along the coast of the Pacific. Its habits are nearly allied to the preceding, with which it sometimes associates.

\section{GENUS SCOLOPAX-LINN.}

\section{SNIPE.}

[Bill long-twice the length, or more, than the head-straight tapering, flattened toward the end ; cyes rather large, placed high in the heat, and far back from the bill; neck of moderate length and rather thick; body full; wings rather long and pointed; tail of moderate length and rounded; legs moderate; toes slender, rather long--hind toe short; midule toe longest, and connected at the base with the inner by a slight web-outer toe free.]

\section{SCOLOPAX WILSONII-TEM.}

\section{WILSON'S SNIPE.}

Scolopax Wilsonii, Bonap. Syn.

Snipe, Scolopax gallınago, Wils. Amer. Orn.

Scolopax W'ilsonii, Wilson's Snipe, Sw. \& Rich.

Wilson's Snipe, Nuti. Man.

American Snipe, Scolopax Wilsonii, Aud.

Specific Character-Upper parts blackish-brown, variegated with pale reddish-brown; the fore neck and fore part of the breast pale reddish-brown, streaked with brownish-black; sides of the body barred with dusky; abdomen white; basal part of tarsi black, toward the end a broad band of brownish-red, succeeded by 
an undulating band of dusky. the tips white. Adult with the bill brown, darker toward the end, and about two inches in length-a dusky band from the bill to the eye; the bands passing over the head, meeting on the occiput, of a darker color; chin dull white; neck, and fore part of the breast, pale reddish-brown, marked with brownish-black; upper parts black, variegated with waving lines of pale reddish-brown; the outer webs of the scapulars edged with pale reddish-white-some of the feathers edged with more pure white; wings dark brown-the outer web of the first white, as are the tips of all, as well as those of the coverts; tail black -rounded, of sixteen feathers, with a broad band of bright ferruginous near the end, and tipped with white; upper tail coverts pale red, barred with black; sides of the body, under wing coverts and lower tail coverts, barred with black-the latter with a pale tinge of red; lower part of the breast and abdomen white; legs and feet pale green. Length ten inches and a half, wing five.

This species is well known to our sportsmen by the name of "English Snipe," to which it bears a resemblance. It differs from that bird, (Scolopax gallinago,) in being rather less, the plumage brighter, and in having sixteen tail feathers. The number of those feathers in the European species is said to be fourteen. It arrives among us early in March, and after spending a short time on the marshy grounds in recruiting, it passes on to the North to breed. In the month of September it returns with its young, and during autumn gets in excellent condition, and is highly prized as game. It is usually found on the wet meadows and low boggy grounds, where it is pursued by the sportsmen, and shot down in great numbers. When flushed, it moves off in an irregular manner, but having flown a short distance, its flight becomes more steady. From the crooked and uneven mode of flying, when put by the gunner, it requires an experienced hand to shoot it. Young sportsmen are apt to be too eager, and fire before they well cover the bird. I have noticed that most of dogs will draw on the American or Wilson's Snipe, more readily than on any other game. Whether this arises from the bird possessing a stronger effluvia, or from the moist nature of the ground it inhabits, I do not pretend to say. It is generally distributed throughout the country, and from 
the following statement in the Fauna Boreali Americana, we may conclude that it proceeds as far North as Hudson's Bay.

"Dr. Richardson states that a specimen of a Snipe from Hudson's Bay, in the British Museum, possesses all the distinctive characters ascribed by the Prince of Musiguano to his Scolopax Wilsonii, of which we have no authenticated examples."

I have been informed that it has been found breeding on Long Island, but I have never met with its nest in that vicinity. In autumn it remains with us until the ground becomes frozen, when it passes on to the South. When rnigrating, it flies high, uttering at intervals a bleating note.

\section{SCOLOPAX NOVEBORACENSIS-GMEL.}

\section{RED-BREASTED SNIPE.}

Red-breasted Snipe, Scolopax Noveboracensis, Wils. Amer. Orn.

Scolopax grised, Bonap Syn.

Scolopax Noveboracensıs, New York Godwit, Sw. \& Rich.

Brown or Red-breasted Snipe, Nutt. Man.

Red-breasted Snipe, Scolopax Noveboracensis, Aud. Orn. Biog.

Specific Character-Spring plumage, upper parts brownish-black, variegated with light brownish-red; lower parts dull orange-red, abdomen paler, spotted and barred with black; rump white; the tail feathers and the upper and lower tail coverts alternately barred with white and black. In autumn the upper parts are brownish gray; the lower parts grayish-white; the tail feathers and the upper and lower tail coverts the same as in spring. Adult with the bill toward the end black, lighter at the base; top of the head, back of the neck, scapulars, tertials, and fore part of the back, blackish-brown, variegated with ferruginous; secondaries and wing coverts clove brown, the latter edged with white-the former tipped with the same; hind part of back white; the rump marked with roundish spots of blackish-brown; upper tail coverts dull white, barred with black; tail feathers crossed with numerons black bands-their tips white; loral band dusky, the space between which and the medial band on the fore part of the head, grayish whise, tinged with ferruginous, and slightly touched with 
dusky; sides of the head spotted with dark brown; lower parts dull orange-red-the abdomen lighter; the neck and fore part of breast spotted with dusky; the sides of the body with numerous bars of the same color; legs and feet dull yellowish-green. Young, with the lower parts paler. Winter dress, the upper parts brownish gray; neck ash-gray, streaked with dusky; lower parts grayish white, with dusky bars on the sides of the body. Length ten inches and a half, wing six.

Our gunners, as if fearful that nothing would be left to connect the past with the present generation, cling to the old provincial names for birds, recognising this species by the singular and unmeaning name of "Dowitcher."

At the close of April, the Red-breasted Snipe arrive on the coasts of Long Island. Invited by a bountiful supply of food, at the reflux of the tide, it resorts to the mud-flats and shoals to partake of the rich supply of shell-fish and insects, which Nature in her plenitude has provided for it. As the tide advances, it retires to the bog meadows, where it is seen probing the soft ground for worms. In the spring, it remains with us but a short time. Soon after recruiting, it obeys the call of unerring Nature, and steers for the North, where it passes the season of reproduction. About the middle of July, it returns with its young, and continues its visit during September-and if the season be open, lingers about its favorite feeding grounds until the last of the month.

The whistling note of the Red-breasted, or "Quail Snipe," as it is termed in some sections of the Island, is well known to the practical bay-gunner, and he so truly imitates it, that the call is obeyed at a great distance. Fond of associating in large flocks, this species is readily decoyed, and is noted for its unsuspicious and gentle manner.

The Red-breasted Snipe is fond of frequenting the fresh ponds that occur on the low parts of the beach or meadow during wet seasons, which situations are more favorable for procuring it, and attended with but little or no fatigue to the gunner, who lies concealed in the rank grass that grows on the salt meadows; or, when shooting over "decoys" placed in ponds on the beach, he adopts 
concealment by making a bed of sea-weed or cut grass, at a conves nient shooting distance. Thus concealed, he has an opportunity of observing what is passing around him. Should a wandering flock meet his eye, or the notes of a distant group fall upon his ear, he pipes his shrill whistle in accordance with their peculiar cry, which is answered by the leaders of the roving band, and echoed by the wily gunner, whose hopes now mount high, as he sees them check their course, wheel, and advance toward the decoys, whose welltrimmed, though silent forms, are made partners to the treachery.

If suffered to alight, it is not unusual for it to spend several minutes in feeding among the decoys before it discovers the deception. Flying close together, and being proverbial for hovering over the silent group that leads them to destruction, the gunner thins their ranks by pouring into the body of the flock his deadly fire. Notwithstanding great havoc is made, it not unfrequently happens that some of those which escape, return and alight among the dead bodies of their companions, sharing-with the reloading of the gunner's piece-their fate.

In dry seasons, when the shallow ponds have disappeared, the scattered flock is observed along the muddy flats, wading about in the shoal water, though seldom venturing beyond knee-deep, and seldom to so great a depth. Even in this exposed situation, but little address is required to approach within shooting distance. I have often had opportunities of witnessing their dullness in being apprised of danger, while they were feeding in company with various species of shore birds.

Long before the gunner thinks of taking aim, the watchful Gull unfolds its wings, and passes still father on from dangerquickly followed by the shy Willet. The less timid Yellow-shanks begins to feel insecure-it moves about with hurried steps-stoops to take one more morsel from the various delicacies that are profusely scattered round it-casts a glance at the approaching gunner, feeling that it has lingered too long for its safety, raises its wings, utters a suppressed and tremulous note, and leaves to fiaish its repast in some distant place of greater security. The host of small Sandpipers that are busily engaged in gleaning their fare, 
become apprehensive, neglect their occupation, take wing and wheel off, leaving the Red-breasted Snipe alone with the gunner. The friendly "Tern," from its elevated and secure retreat, observes what is passing below, flies around in circles, uttering loud screams, urging the loiterers to depart, which kindly warning is unheeded until the sportsman has arrived too near for the game to escape. As he levels his gun, the terrified Snipe becomes aroused, springs up, and the next instant lies like a clod upon the muddy shore.

The Red-breasted Snipe is capable of rapid and protracted flight, at times performed to a great elevation. During dry scasons, when in search of its favorite pools, it flies liigh, and at such times is not so readily decoyed. At Egg Harbor, where it is abundant, it is called by the gunners " Brown-back."

\section{GENUS MICROPTERA-NUTTALL.}

\section{BOGSUCKER.}

[Bill twice the lenglh of head-straight, tapering, deeper than broad at baseslightly depressed toward the end; upper inandible witt a narrow groove on the sides, extending to near the tip, which is blunt, and longer than the lower; head rather large, oblong; eyes large, placed high; necls shurt; body full ; wings short. rounded; tail very short, of twclie featbers; tarsi shorter than the middle toes.]

\section{MICROPTERA AMERICANA-AUDUBON.}

\section{AMERICAN WOODCOCK.}

Woodcock, Scolopax minor, Wils. Amer. Orn.

Scolopex minor, Bonap. Syn.

Lesser Wuodcock. Nutt. Man.

American Woodcock, Scolupax minor, Aud. Orn. Biog

Specific Character-Upper parts variegated with brownish-black, light yellowish-red and ash gray ; lower parts light yellowish-red. Adult male with the bill and feet flesh color-the former black toward the end, with the upper mandible extending beyond the lower; forehead gray, tinged with pale reddish.yellow; a short black line from the ridge of the upper mandible; a decurved black band from the nostrils to the eye; a line behind the eye, and a similar band crossing the cheeks; upper part of the head and occi. 
put black, crossed with narrow bands of light red; sides of the neck ash color; the feathers marked with dusky and tinged with light red; back black, the feathers marked with numerous bars of light yellowish-red; outer webs of the scapulars and tips of the wing coverts ash-gray; quills plain brown, tipped with dull gray; outer webs of secondaries spotted with dull red; tail feathers black, their outer edges marked with small spots of reddish-brown, their tips white brown above and silvery white below; upper tail coverts barred with reddish-brown and black; chin white; lower parts light red, the middle portion of the breast paler; lower tail corerts with a central dusky streak, and tipped with white. Female about one inch longer, and an inch and a half greater in extent.

Length of male ten inches and a half, wing five and a half.

This bird, well known to our sportsmen, arrives on Long Island early in March. Its migrations extend as far as Nova Scotia, where, according to Audubon, it breeds, as well as in the interme. diate districts. It is seldom seen flying about during the day, but usnally keeps in the close and sheltered thickets; at twilight it resorts to neighboring springs for the purpose of feeding on small worms and other insects, which it procures by boring into the ground with its bill. If the season be unusually wet, it retreats to the high and dry grounds, but in general prefers low and marshy situ. ations convenient to springs and watery piaces. Early in April it commences building its nest, which is formed of withered leares and dry grass, and apparently devotes but little attention to its structure. The egers, which are from four to five in number, are of an carthy color and spotted with brown. On the first of July the Act which prohibits the shooting of Woodcock expires. So cager then are the gunners for the sport, that every favorable piece of ground convenient to the city is oceupied immodiately by the sportsmen and their dogs. For the table it is highly cstcemed, and commands a high price in our markets, particularly in the carly part of the season, although I think it is then quite inferior to those procured in autumn. The season for shooting Woodcock continues to the first of February, when it is again protected by law. Sportsmen generally observe this law, but those persons who shoot to gratify the palate of the epicure commence previous to the first 
of July, or as soon as their dogs can find a bird to point, notwithstanding a fine is imposed for every bird found in their possession, when out of season.*

When flushed, the Woodcock rises to the height of the bushes or undergrowth, and quickly drops behind them again, usually rur. ning a short distance as soon as it touches the ground. Being very tender but little force is required to kill it, and as it presents only a momentary mark, none but practised sportsmen can succeed.

I once heard a gentleman boast of having a day of fine sport in cover, which was so close, that in the ordinary mode of shooting from the shoulder, he could not have bagged a bird. He shot from the hip - a mode but little practised among us. I have heard sportsmen assert that they have shot three species of Woodcock. These differnces are attributable to sex and age.

The whistling noise when rising, is produced by the action of its 'wings. Its note is a sudden quack, which is not often heard except in spring, when at that season toward dusk it mounts in the air, uttering whistling notes, which are continued till a late hour during evening. In its habits, it is said to be allied to the European Woodcock. On comparing the two species, I find the European bird to be much larger, with the lower parts dull yellowish-white, and barred with black; while those parts of our bird are light red without the black markings.

In England, I am informed that during the season of Woodcock shooting if a good sportsman procure a brace in a ray, it is considered fair sport; while with us, from six to eight brace would be thought moderate shooting. The season for shooting Woodcock in England is during the winter months. Early in the spring it moves off to the northern part of the continent, where it breeds. With us the Woodcock remains until late in autumn, when it migrates southward. Near Jamaica, Long Island, in wet, springy places, a few have been seen in the months of December and January. During the season of incubation, the males associate apart from the females, and I do not think they pair.

* "No person shall bring into any market or sell or offer or exjose for saje any Wondeock, in any market or other place in the city of New York, between ths first day of February and the first day of July in any year, under the penalty of ten dollars for each offence."-City Ordinance. 


\title{
GENUS RECURVIROSTRA-LINN.
}

\author{
AVOCET.
}

[Bill more than twice the length of the head, depressed, tapering, straight for half its length, lower in the middle, raising toward the point which is decurved; head small, compressed, rounded above; neck long-body full-wings longtail short, even, of twelve feathers-legs very long--feet long, slender-hind toe very small-anterior toes connected by deeply emarginate webs.]

\section{RECURVIROSTRA AMERICANA-LINN.}

\section{AMERICAN AVOCET.}

\author{
Recurvirostra Americana, Wils. Amer. Orn. \\ Recurvirostra Americana, Bonap. Syn. \\ American Avocet, Recurvirostra Amerirana, Sw. \& Rich. \\ American Arocet, Nutt. Man. \\ American Avocet, Recurvirostra Americana, Aud. Orn. Biog.
}

Specific Character-Loral space white; neck and fore part of breast reddish-buff; lower parts, the back, and tail white ; a band of black on the fore part of the back ; inner scapulars black, outer white; inner secondaries white; wings black, with a broad band of white, formed by the tips of the secondary coverts; lower portion of tibia naked; legs blue. Length eighteen inches, wing rine.

The habits of this bird are very similar to those of the Stilt, to which in form it has some resemblance. It is less frequent with us than the preceding, and is not generally known to our gunners. It frequents the shallow pools in the salt marshes, and like the former species, is sometimes seen wading breast-deep in pursuit of its favorite fare.

A few breed at Egg Harbor, where they are called "Bluestocking," their legs being of that color. Its nest is built among the thick tufts of grass, usually near some favorite pool, making use of similar materials in its construction as the Stilt. The number of eggs is also the same, and differ only in having the ground color dull olive. A few are seen in various parts of the United States; and they are said to be very abundant in the Fur countries. 


\title{
GENUS HIMANTOPUS.
}

\author{
STII,T.
}

[B.li much longer than the head-slender, tapering, and s'ightly reeurvedhead small, compressed, rounded above ; neck long and slender; legs very lorg-body compact-wings long-hind toe wantiug; toes slender, and connected at the basc-middle loe longest-lail short, even.]

\section{HIMANTOPUS NIGRICOLLIS-VIEILL.}

\section{BLACK-NECKED STILT.}

I.ong-legged Avocet, Recurvirostra Himantopus, Wils. Amer. Orn.

Hunantopus uigricollis, Bonap. Syn.

Black-necked Silt, Nutt Man.

Black-necked stilt, Himantopus nigricollis, Aud. Orn. Biog.

Specific Character-Bill black; forehead, loral space, a spot over the eye, lower eyelid, fore part and sides of the neck, with the entire lower parts, tail, and hind part of back, whitc; upper part of head, nape, and a spot on the sides of the head, brownishblack; fore part of back and scapulars brown; wings bluish-black, glossed with green; legs long, slender, yellow. Length fourteen inches, wing eight and a half.

With 1is, tha Black-necked Stilt, or "Lawyer" as the gunners term it, is not common. On the sea coast of New Jersey, where they arrive from the South in the latter part of April, they are more plentiful. They usually associate in small parties, and resort to the shallow pouds on the meadows in the vicinity of the sea coast, where they arc observed wading about in pursuit of minute shell-fish and aquatic insects.

Occasionally they are seen loitering about the pools on the southern shores of Long Island; but so seldom, that those who visit us are considered mere stragglers. The few that I have at different times procured in this vicinity, have always been alone; and in conversation with the gunners, they speak of it as being with them un. 
frequent-and it is rarely seen exposed for sale in the New York markets.

lts nest I have never found, and do not think it breeds on Long Island. At Egg Harbor, I have been informed it breeds. Early in May it commences building its nest, which is formed of sea-iveed, dry salt-grass, and other coarse materials. The eggs are four, of a yellowish clay-color, blotched with black. In autumn, migrates southward.

\section{GENUS NUMENIUS-BRISS.}

\section{CURLEW.}

[Bill very long, slender, decurved or arched-upper mandible Ionger, obtuse at the end-head rounded, above compresscd-neck long-body full-wings Iong-feet rather long-toes connecled at the base-tibia bare a short space above the knee-legs rather long-tail short, rounded.]

\section{NUMFNIUS LONGIROSTRIS-ẄILSON.}

\section{LONG-B!LLED CURLEW.}

Specific Character-Bill soward the end decurvel; upper part of the throat, and a band from the bill to the cyc, light buff; gen. eral plumage pale reddish-brown; head and neck streaked with dusky; upper parts marked with blackish-brown; tail barred with the same; abdomen plain reddish-brown; feet bluish. Length twenty-six inches, wing eleven. The bill of the specimen from which this description is taken, measures eight inches. The bills of individuals of this species vary, but the length is at all times sufficient to determine the species.

This bird is more abundant at the South. On "Folly Island," about tiventy miles below Charleston, I am informed that many of them breed. They are regular visiters at Egg Harbor and Long Island in the spring and summer, and have been seen in the latter place as late as the middle of November. Mr. Brasher informs me that he has met with it on the prairie lands in Illinois in the month of May. 
The Long-billed Curlew, or "Sickle-bill," as many term it, frequents the muddy shores of beaches and marshes, where it collects minute shell-fish, which, with worms, and various insects, constitute its food. When moving about in flocks, they fly much after the manner of Wild Geese, the leaders uttering a hoarse, dull note, which, by imitating, the group readily obeys, and are proverbial for answering the fowler's call when at a greater distance from his decoys than any other species of shore birds. When approaching near to the decoys, they spread their wings, and sail slowly up, presenting such a fair mark, that those singled out by the gunner seldom escape. Its flesh is rank, the young partaking of the same flavor. The sympathy existing in these birds is so strong, that I have known of instances of flocks being kept within gun-shot by the cries of their wounded companions, until as many as fifteen have shared a similar fate.

The Long-billed Curlew is said to be one of the Egyptian divinities, and is embalmed and entombed with the Ibis and other sacred birds.

\section{NUMENIUS HUDSONICUS-LATHAM.}

\section{HUDSONIAN CURLEW.}

Esquimaux Curlew, Scolopax borealis, Wils. Amer. Orn.

Numenius Hudsonicus, Bonap. Syn.

Numenius Hudsonicus, Hudsonisn Curlew, Sw. \& Rich.

Esquimaux Curlew, Numentus Hudsonicus, Nult. Man.

Hudsonian Curlew, Numenius Hudsonicus, Aud. Orn. Biog.

Specific Characier-Length of bill three inches and three quarters ; tarsi two inches; lower parts white. Adult with the upper part of the head deep brown, with a central and two lateral lines of whitish; a brown line from the bill to the eye, and another behind the eye; neck all round pale yellowish-gray, longitudinally streaked with brown, excepting the upper part of the throat, which is grayish white; upper parts in general blackish-brown, marked whth numerous spots of brownish.white, there being several along 


\section{(273)}

the margins of each feather; wings and rump somewhat lighter; upper tail coverts and tail barred with dark brown and olivaceous gray; primaries and their coverts blackish-brown, all with transverse yellowish-gray markings on the inner web; the shaft of the first quill white-of the rest brown; breast and abdomen grayishwhite, the sides tinged with cream-color, and barred with grayish brown; bill rather more than twice the length of the head, of a brownish-black color - at the base of the lower mandible, flesh-colored. Length eighteen inches, wing nine and a half.

This bird arrives on Long Island in the month of May. It frequents the marshes and muddy flats, feeding on worms and minute shell-fish. With us, it is not so abundant as the long-billed species, with which it sometimes associates. Early in June it moves on to the North, where it passes the season of re-production; in the latter part of August, while journeying southward, it again makes its appearance on the salt marshes; and sometimes it frequents the uplands, where it procures berries and insects of various kinds, on which it gets very fat-thongh in general its flesh is not well flavored.

The flight of the Hudsonian Curlew is easy and steady; it obeys the fowler's whistle, and presents an excellent mark. This bird is remarkable for sympathizing with its wounded companions -a trait of character so proverbial in the Long-billed Curlew.

Occasionally stragglers are observed to linger behind until the early part of November; but in general, all have left for winter quarters by the middle of October. The name generally given to it by our gunners, is "Short-billed" or "Jack Curlew." 


\section{NUMENIUS BOREALIS-LATHAM.}

\section{ESQUIMAUX CURLEW.}

Numenius horealis, Bonap. Syn.

Numenius borealis, Esquimaux Curlew, Sw. \& Rich.

Esquimacx Curlew, Numenius burealis, Nutt. Man.

Esquimaux Curlew, Numenius borealis, Aud. Orn. Biog.

Specific Character-Bill along the gap about two inches and $a$ quarter; tarsi one inch and five-eighths; upper parts dusky brown with pale yellowish-white, marked all orer with pale reddish-brown. Adult with a line of white from the bill to the eye; eyelids white; upper part of the liead dusky, spotted in front with grayish-white, a medial band of the same color; throat white; neck and breast yellowish-gray; with longitudinal markings of dusky on the former, pointed spots of the same color on the latter; abdomen dull yellowish white; flanks barred with brown; lower tail coverts the same as the abdomen; tail and upper tail coverts barred with pale reddish-brown and dusky, tipped with yellowish-white; upper parts brownish, the feathers tipped with pale reddish-brown, the scapulars margined and tipped with lighter; primaries dark brown, margined internally with lighter-the first shaft white, with the tip dusky-the rest brown. Length fourteen inches and a half, wing eight.

In New Jersey, New York, Massachusetts, and Rhode Island, this species is seen every season. It frequents the open grounds in the vicinity of the sea-coast, feeding on grasshoppers, insects, seeds, worms and berries. It arrives among us in the latter part of $\mathrm{Au}$ gust, and remains until the first of November, when it assembles in flocks, and moves off to its winter quarters, which are said to be South of the United States. I have shot a few stragglers in this vicinity as late as the twentieth of November. It occasionally associates with the Golden Plover. In the autumn it is generally in fine condition, and unlike the former two, its flesh is well flavored. In the vicinity of New York it is known by the name of "Futes"in the Eastern States it is called "Doe Bird." It breeds on the barren grounds at the North. 


\section{F A M I L Y T A N T A L I N}

\section{IBISES.}

\section{GENUS IBIS-CUVIER.}

IBIS.

[Bill very long, arched, compressed, slender-higher than broad at the base ; head small, naked; neck long and slender; wings long; tail short; fect long, slender-anterior toes conrected ly membranes at base.]

\section{IBIS ALBA-LINN.}

\section{WHITE IBIS.}

White Ibis, Tantalus albus, Wils. Amer. Orn.

Ibis albu, Bonap. Syyn.

White This, Nutt. Man.

White Ibis, Ibis alba, Nutt. Man.

Specific Character-General color of the plumage white, with the ends of the outer primaries black; bill very long, slender, reddish orange; neck long, slender; tail feathers short. Young dull brown, excepting the rump, which is nearly white; bill grayish yellow ; feet lead color. Length of adult about two feet, wing twelve inches.

Of the four species of Ibis which have been found within the limits of the United States, the present is the only species which I have any knowledge of ever having been observed in this vicinity, a single specimen of which was shot at Raynor South in the summer of 1836 , and is now contained in the cabinet of the New York [late Peale's] Museum. Another, procured at Moriches in the early part of March, 1843, and which is now in the possession of Mr. Brasher, are the only instances, as far as I have been informed, of its occurring with us.

"In Florida, the White Ibis is said to be abundant, and is found there at all seasons of the year; it is likewise not uncommon in the southern part of Louisiana, and in Georgia, though rarely seen north of Carolina." 


\section{F A M I L Y A R D E I N E.}

\section{HERONS.}

\section{GENUS ARDEA-LINN. HERONS.}

[Bill longer than the head-stout, tapering, pointed; head compressed; neck very lorig-legs long and slender-larger portion of the tibia bare-larsus compressed-claws long, arched, acute-that of the hind toe much larger-wings long and broad-tail short, consisting of twelre feathers.]

\section{ARDEA HERODIAS-LINN.}

\section{GREAT BJUE HERON.}

Ardea Herodias, Wils. Amer. Orn.

Ardea Heiodias, Bonap. Syn.

Great Heron, Aruea Herojias, Nult. Man.

Great Blue Heron, Ardea Heroidas, Aud. Orn. Biog.

Specific Character-Bill seven inches and a quarter, tarsi six inches; bill yellow, stout, gradually tapering to a point; upper mandible a quarter of an inch longer than the lower. Adult with the crown white, broadly banded with black, with occipital plumes -cheeks and throat white; neck ash-color, with a longitudinal band on the fore neck, white, spotted with bluish-black; a tuft of long feathers on the lower portion of the fore neck; flanlis bluish; breast and abdomen black and white; thighs reddish-brown; tail, back, and wing coverts grayish-blne; primaries bluish-black; shoulders of the wings rufons; under tail coverts pure white. Length four feet, wing eighteen.

On the salt marshes of Long Island, the Great Blue Heron is common. On the north shore of the South Bay, it is but seldom met with, confining itself almost entirely to the wet and miry marshes in the vicinity of the beach. In its habits it is diurnal as well as nocturnal, and is observed by day wading out on the shoals, collecting crabs and various species of shell-fish-and at times it is seen standing in the water up to its knees, with its bill poised orer 
the surface, watching for finned prey. On such occasions, the gunner well knows that it is useless to attempt securing it, as it is not only rery shy, but when standing erect-which watchful attitude it sometimes adopts-its head is elevated about five feet from the ground, which gives it an opportunity of observing what is passing within a wide circle. Should yon attempt to pursue it, you will find, as I often have, that before you have advanced within two or three times the distance that your gun will carry-notwithstanding that it may be a very excellent one-the object of pursuit is aware of your intention, and is leisurely moving off. If you have never shot a Blue Crane, I doubt not that you desire to do so. You mark it down, and try it again; but before you have approached as nigh as before, you find that its vigilance has increased with your resolution-and the next stride you make, the bird is off.Unwilling to relinquish the pursuit, you watch for it to alight-or perchance you espy another feeding in the vicinity of a "thatch." This seems to offer a more favorable opportunity, as you can proceed under cover of the tall grass-and success now seems almost certain. With lowered body and gun, perchance advancing in a creeping manner, you conmence the exciting task. A few seconds more, and you will be within the desired distance-which, on gaining, with finger on the trigger, you cautiously raise your gunwhen behold! your mark is gone! On glancing up, you see its long legs projecting beyond its tail feathers, and the steady flapping of its broad wings carrying it far beyond your reach. Faligued and disappointed, you give over the pursuit, and make up your mind that the Blue Crane is an exceedingly wary bird, and under similar circumstances you will not again attempt to capture it.

Notwithstunding all its watchfilness, the vigilance of the Great Blue Heron is not at all times equal to the fowler's ingenuity.Lilie many other birds which are next to inıpossible to approach unless you visit their brecding-places, the Blue Crane is enticed within gun-shot throngh the agency of decoys. When shot in the air, while falling, its long legs, neck, and wings dangling together, it presents a ragged sight. One who has never seen the Blue Heron, except when at large, would be likely to suppose that by pos- 
sessing it, he would have provender for several days; but after di. vesting it of the legs, neck, and wings, the body is left in a small compass. Its flesh is by many highly esteemed; and I remember that the first I partook of, I thought, was excellent, while taking gunner's fare in a bayman's lodge, on the beach opposite Bellport. On similar occasions I have also relished the dark-colored flesh of the "Velvet Duck," and have considered that of the "Goosander" a delicacy. I have since eaten of it under different circumstances. Though palatable, there are many other articles of food less prized by some, which I prefer to it or any of our shore birds. Should you wish to procure a Blue Crane, the most convenient distance from the city of New York that I can recommend to you, is South Oyster Bay. There inquire for that experienced bayman and very worthy man, known to all sportsmen who frequent that section of the Island, by the name of John Verity. He will furnish you with a suitable boat and decoys, and accompany you; and if you visit him at the proper season, I will guarantee that you will return with game, even if you should be unskilled in the art of taking aim - his gun will make amends for all your random shots.

At night, after the last report of the murderous gun has died away, and the gunner is resting in a glorious state of unconsciousness, theu the Blue Heron, with other nocturnal waders, venture more fearlessly forth from their secluded residence, to satisfy the demands of appetite. On wading to a certain depth, they stand motionless, and with poised bills, silently wait their expected prey. In this position the plumage is parted, exposing a portion of the breast, which is furnished with a downy substance, emitting a phosphorescence. By some persons it is called the bird's lantern, and is said to be as serviceable to it when fishing, as the bayman's light is to him when out at night "jacking" or eeling, by attracting his prey, and showing him where to strike. On such occasions 1 have never observed it, but so I have been told. At night, I hare frequently examined, in dead specimens, this luminous substance, which gives out a pale glow, not unlike that produced by decayed timber, familiarly termed "light wood," or "fox fire." 
The Blue Heron is said to be a constant resident in all the Southern States, and according to Wilson, its nest has been found in the lower parts of New Jersey, of which, and their manners during the season of incubation and rearing their young, he gives the following account:

"On the top of the tallest cedars, the Herons construct their nests, ten or fifteen pairs sometimes occupying a particular part of the swamp. The nests are large, formed of sticks, and lined with smaller twigs; each occupies the top of a singie tree. The eggs are generally four, of an oblong, pointed form, larger than those of a hen, and of a light greenish-blue, without any spots. The young are produced about the middle of May, and remain on the trees until they are full as heavy as the old ones, being extremely fat before they are able to fly. They breed but once in the season. If disturbed in their breeding place, the old birds fly occasionally over the spot, sometimes honking like a goose, and sometimes uttering a coarse, hollow, grunting noise, like that of a hog, but much louder."

\section{ARDEA NYCTICORAX-LINN.}

\section{BLACK-CROWNED NIGHT HERON.}

Ardea nycticorax, Wils. Amer. Orn.

Ariea nycticotax, Bonap. Syn.

Qua.bird, or American Night Heron, Ardea discors, Nutt. Man.

Night Heron, Ardea nycticorax, Aud. Orn. Biog.

Specific Character-Bill black, stout at base, gradually tapering to the end ; from the corner of the mouth to the end of the upper mandible about four inches and a half long; the lower mandible is three-eighths of an inch shorter; toward the point dull yellow, or horn color ; upper mandible much curved toward the point ; length of tarsi three inches and an eighth. Adult with the upper part of the head black, glossed with grecn, with three long occipital plumes rolled into one; throat white; fore part of the neck cream color; sides and hind part of the neck light grayish-white, with a slight tinge of lilac; back deep bluish-green; wings, tail, and 
rump, ash color, shaded with grayish-blue; lower parts whiteYoung without the plumes, and of a dull grayish-brown color. Lengtl of adult twenty-five inches and a half, wing twelve and a quarter.

The migrations of the Night Heron seldom extend far into the interior, but on most parts of the sea const of the United States it is common during summer. In the Southern States it is a constant resident. It visits Long Island in the early part of April, and continues until quite late in autumn, and I have heard of its being seen there in the depth of winter. It inl:abits the overgrown margins of water-courses and ponds. It seldom ventures abroad by daylight ; and ai such times is rarely seen, unless met with by accident. At twilight it is secn flying over the marshes, and following the streams, reconnoitering for food, which consists of fishes, frogs, mice, lizards, and like prey. When roarning about at niglit, it is lieard uttering at intervals a lond guttural sound,from which it has by gunners received the appellation of "Quack" or "Quawk."

\title{
ARDEA VIOLACEA-LINN.
}

\section{YELLOW-CROWNED NIGHT HERON.}

\author{
Ardea violacea, Wils Amer. Orn. \\ A rilea violacea. Boisap. Syn. \\ Whitc-crowned Hcron, Nutl. Man. \\ Yellow-crowned Heron, Ardea violacea, Aud. Orn. Biog.
}

Specific Character-Length of bill from the corner of the mouth to the point about three inches and a half; bill black, strong, the edges of both mandibles rough toward the end ; the bill at base is swelled, or bulging, and retains that character the greater portion of its length ; toward the end compressed; the lower mandible is more rounded than that of the Black-crowned Night Heron, and scarcely shorter than the upper, the point of which merely extends beyond it ; length of tarsi three inches and five-eighths. Adult 
with the fore part of the head and crown white, tinged with yellow; occipital plumes white; the feathers on the upper part of the head rather long, and pointed; a band of white under the eye extending backwards; rest part of the head and the throat greenishblack; fore part of back, tertials, scapulars, and wing coverts, with broad central black streaks, margined with bluish-white; quills and tail feathers dark grayish-blue, margined with bluishwhite; general color of the plumage light grayish-blue. Length twenty-two inches, wing eleven and a half. Young with the upper parts dark grayish-white; lower dull yellowish-white, strealed with dusky.

The Yellow-crowned Heron seldom extends its visits to Long Island, being principally confined to the Southern States. In its habits it is chiefly nocturnal, lieeping in the marshes during day, and feeding mostly at night. In the neighborhhod of Charleston, S. C., a few breed. Mr. Bell found this species, the White Egret, Blue, and Louisiana Heron, breeding in society. According to Catesby, it is quite common in the Bahama Islands, where it is said to feed principally on small crabs, and its flesh is highly esteemed.

\section{ARDEA LUDOVICIANA-WILS.}

\section{LOUISIANA HERON.}

Louisiana Heron, Ardea ludoviciana, Wils. Amer Orn.

Ardea ludoviciana, Bonap. Syn.

Louisiana Heron, Nutt. Man.

Louisiana Heron, Ardea ludoviciana, Aud. Orn. Biog.

Specific Character-Bill rather slender, at base yellowish-green, toward the point brownish-black; length from the corner of the mouth to the end, four inches and an eighth; length of tarsi three inches and eleven-sixteenths; upper parts, and neck all round, blue, tinged with purple; lower parts and the under lining of the wings, and the throat white; a broad line intermixed with reddish brown, blue, and white, extends the entire length of the fore neck, the feathers on the head and neck, long, tapering; occipital 
plumes white. The length and form of the bill is at all times sufficient to determine this species. Adult with the bill brownishblack above, yellow beneath; head and sides of the neck blue, tinged with purplish-red; upper part of the throat white, lower part reddish; a longitudinal line on the fore neck, the feathers at base white, succeeded by reddish.brown, and broadly tipped with purplish-blue; upper parts light purplish-blue; the loose hairy feathers on the hind part of the back dull purplish-yellow; lower parts white; feet greenish-yellow; the feathers on the head and neck are long and tapering, with the six longest feathers of the head white; the plumage on the hind part of the back is very long, extending beyond the tail, which is even, of a fine slate co. lor. Length twenty-seven inches, wing ten and seven-eighths.

This is another of those birds that chiefly inhabit the warmer parts of the Union. Its occurrence as far eastrvard as the lncality from which we are describing, is so exceedingly rare, that with us it may be considered entirely accidental. A single specimen, shot near Patchogue in the summer of 1836 , is the cnly individual of this species that $I$ have known to be procured in this vicinity.

According to $\mathrm{Mr}$. Audubon, "it is a resident in the Floridas and Texas, where it is abundant. Migrates eastward to New Jersey, where it is rare, and up the Mississippi to Natchez. Never seen far inland."

\section{ARDEA COERULEA-LINN.}

\section{BLUE HERON.}

Blue Heron, Ardea coerulea, Wils. Amer. Orn.

Bine Heron, Nutt. Man.

Blue Heron, Ardea cocrulea, Aud. Orn. Biog.

Spccific Character-Bill rather slender, at base blue, toward the point black, about three inches and a half long; head and neck purple, with a longitudinal blue line on the fore neck; the feathers on the upper part of the head long and slender those on the occiput much longer; general color of the plumage blue; the feathers on 
the middle of the back extending about four inches beyond the tail. Length twenty-three inches, wing ten and a half. Young white, gradually changing to blue as it advances in age.

This species is said to be common in Jamacia and other West India Islands; it is also a resident of the Southern States, and has been found breeding in the intermediate districts from Florida to New Jersey. During summer, stragglers occasionally wander as far as Massachusetts, where, as with us, it is rare.

Though seeming to have a partiality for the marshes along the Atlantic districts, it is not altogether confined to the sea coast: it frequents the fresh water bogs in the vicinity of the interior streams -and according to Wilson, is observed along the muddy shores of the Mississippi, in the neiginborhood of New Orleans.

\section{ARDEA CANDIDISSIMA-GMEL.}

\section{SNOWY HERON.}

Suowy Heron, Aruea candidissima, Wils. Amer. Orn.

Ardea candidissima, Bonap. Syn.

Snowy Heron, Arlea candidissima, Nutt. Man.

Snowy Heron, Ardea caididissima, Aud. Orn. Biog.

Specific Character--Plnmage pure white; the feathers on the upper part of the head, occiput and lower part of the fore neck long and slender; the back is furnished with long loose hairy feathers; bill and legs black; toes yellow. Length of adult two feet, wing ten inches and five-eighths. Young, white-a yellowish tinge on the nape and back; legs and toes dull green.

During the summer months, this elegant species is found as far east as Massachusetts. On Long Island it is not abundant, though by no means uncommon, and is known to the gunners by the name of "White Poke." In small parties, they frequent the salt marshes, mud-flats, and sand-bars, and are observed rading about in the shallow water, in search of small crabs, lizards and worms-which, with several species of aquatic plants, constitute their food.

T'he Snowy Heron feeds by day, and when wading about in search of its favorite fare, or while making short excursions through 
the Bay, it is rendered so conspicuous from the snowy whiteness of its plumage, that it seldom passes unobserved by the gunner.

Wilson found this species breeding among the red cedars of Somer's Beach, on the sea coast of Cape May? "Some trees contained three, others four nests, built wholly of sticks. Each had in it three eggs, of a pale greenish-blue color, and measuring an inch and three quarters in length, by an inch and a quarter in thickness -which are well tasted."

The Snowy Heron visits us late in the spring, and is observed on the salt marshes until late in the autumn, though usually it migrates southward about the last of September.

\section{ARDEA VIRESCENS-LINN.}

\section{GREEN HERON.}

Ardea virescens, Wils. Amer. Orn.

Ardea virescens, Bonap. Syn.

Green Heron, Nutt. Man.

Green Heron, Ardea virescens, Aud. Orn. Biog.

Specific Character-Bill black, lighter beneath; from the corner of the mouth to the point three inches; length of tarsi one and seven eighths; legs and feet yellow. Adult with the upper part of the head deep green; the feathers rather long; a short band of the same color below the eye; sides of the head, sides, and hind part of the neck, reddish-brown, tinged with purple; a band of white, spotted with dusky, extending the entire length of the fore neck; lower parts purplish, tinged with yellow; the fore part of the back is furnished with long, narrow, purplish-green feathers; primaries and outer secondaries brown; a small spot of white on the tips of the latter; the outer webs of both tinged with bluishgreen; inner secondaries, wing coverts, tertials and scapulars, green, bordered with yellowish-white; hind part of back and tail deep green. Length eighteen inches, wing seven and a quarter. Young without the long feathers on the back, the lower parts chiefly white. 
On Long Island, the Green Heron is not so abundant as it is in many places in the interior, though sufficiently common to be known by the cognomen which it universally goes by; and which we cannot here with propriety indite.

It arrives among us about the middle of April, and frequents low, marshy situations. It hunts by day, and shows a great deal of address in taking its prey. It feeds on frogs, lizards, and various reptiles that inhabit the low boggy grounds. It visits the neighboring mill-ponds and creeks-is a dexterous fisher-and at times darts down after small eels, with which it mounts in the air, amusing itself with dropping and catching them before they reach the water-and from this performance, singular notions respecting its internal organization have arisen.

\section{ARDEA LENTIGINOSA-SWAINSON.}

\section{AMERICAN BITTERN.}

American Bittern, Ardeo minor, Wils. Amer. Orn.

Ardea minor, Bonap. Syn.

American Bittern, Ardea lentiginosa, Sw. \& Rich.

American Bittern, Nutt. Man.

American Bittern, Ardea minor, Aud. Orn. Biog.

Specific Character-Bill from the corner of the mouth to the point about three inches and a half, tapering to a point; both mandibles about equal in length; the upper black, the lower greenish-yellow; length of tarsi three inches and an eighth; legs and feet yellowish-green; the general plumage mottled and streaked with yellowish-brown, reddish-brown, and dusky. Adult with the upper part of the head dusky, the feathers on the hind part of the head rather long and loose; throat white, with a central streak of brown; fore part of the neck yellowish-brown, margined with dusky and yellowish-white; sides of the neck and nape yellowish, or greenish-brown, spotted with reddish-brown, a patch of bluishblack on the upper part of the former; upper parts barred and spotted with yellowish-brown, reddish-brown, and dusky; lower 
parts dull yellowish, the feathers with central streaks of dark brown; feet dull yellowish-green. Length twenty-seven inches, wing ten and a half.

This species is said to have been the favorite bird of the Indians, and at this day is known to many persons by the name of "Indian Hen," or "Pullet," though more familiarly by the appella. tion of "Look-up," so called from its habit, when standing on the marshes, of elevating its head, which position, though probably adopted as a precautionary measure, frequently leads to its destruction. The gunners seem to have a strong prejudice against this unoffending bird, and whonever opportunity offers, seldom allow it to escape. It does not move about much by day, though it is not strictly nocturnal, but is sometimes seen flying low over the meadow, in pursuit of short-tailed or meadow-mice, which I have taken whole from its stomach. It also feeds on fish, frogs, lizards, \&c. ; and late in the season, its flesh is in high esteembut it cannot be procured in any number except when the marshes are overflowed by unusually high tides, when it is hunted much after the manner the gunners adopt when in pursuit of Rail. On ordinary occasions, it is difficult to flush; the instant it becomes aware that it has attracted the attention of the fowler, it lowers its head and runs quickly through the grass, and when again seen, is usually in a different direction from that taken by its pursuer, whose movements it closely watches; and when thus pursued, seldom exposes more than the head, leading the gunner over the marsh without giving him an opportunity to accomplish his purpose.

When wounded, it makes a vigorous resistance, erects the feathers on the head and neck, extends its wings, opens its bill, and assumes a fierce expression-will attack the dog, and even its mas. ter, and when defending itself, directs its acute bill at its assailant's eye. It does not usually associate with other Herons, nor does it seem fond of the society of its own species. Singly or in pairs it is distributed over the marshes, but with us it is not abundant. 


\section{ARDEA EXILIS-WILSON.}

\section{LEAST BITTERN.}

Least Bittern, Ardea exilis, Wils. Aner. Orn.

Ardea exilis, Bonap. Syn.

I.east Butern, Ardea exilis, Nutt. Man.

Least Bittern, Ardea exnlis, Aud. Orn. Biog.

Spccific Character-Bill slender, tapering to an acute point, length from the corner of the mouth to the end two inches and an eighth; the ridge of the upper mandible black, the sides and the lower mandible yellow; length of tarsi one inch and three-eighths. Adult male with the bill rather slender, yellow-the ridge black, and sharply pointed; the feathers on the upper and hind part of the head rather long; crown greenish-black; sides of the head and part of neck light chestnut; back glossy greenish-black; wing coverts brownish-yellow; quills purplish-gray, tipped with yellowish brown; secondary coverts light chestnut; inner secondaries broadly margined with the same; throat and fore neck reddish white; fore part of breast, under the elongated feathers, blackish brown; rest of the lower parts reddish-white; tail feathers greenish black; lower portion of tibia naked; feet yellow. Length thirteen inches, wing four and five-eighths. Female smaller, with the plumage duller.

This species-more common at the South-is during the summer months distributed throughout the country. It is usually found among the tall grass and reeds along the margins of fresh water streams. A few have been procured on the salt meadows near Babylon; and on the Hanover meadows, near Pine Brook, New Jersey, it is not uncommon. It is also occasionally shot along the borders of the Hackensack River. A superb specimen that was shot at Gowanus, a few miles from the city of Broolilyn, is now in the possession of Mr. Brasher, who informs me that on the four- 
teenth of July of the present year, he shot seven individuals of this species in a swamp near Fort Hamilton-and at the same place found the young; they were unable to fly, and were covered with yellowish down. It feeds chiefly at night, and is seldom seen flying during the day-and, like many other species that take shelter among the rank grass and rushes which grow on the wet, miry grounds, it is not as scarce with us as is by many supposed.

\section{ARDEA EGRETTA-GMEL.}

\section{GREAT AMERICAN WHITE EGRET.}

Great White Heron, Ardea Egretta, Wils. Amer. Orn.

Ardea alba, Bonap. Syn.

Great White Heron, Nutt. Man.

Great American Egret, Ardea Egretta, Aud. Orn. Biog.

Specific Character-Bill from the corner of the mouth to the point five inches, yellow, upper mandible toward the point dusky; legs black; length of tarsi five inches. Adult with the plumage white; bill yellow; feet black; the plumage on the fore part of the back long and hairy, extending beyond the tail eight or ten inches, and slightly tinged with yellow. Length three feet two inches, wing fifteen inches and a half.

On Long Island, this large and elegant bird is not a frequent visiter. During the summer months, it is occasionally seen on the marshes and meadows, or wading about on the shoals in pursuit of small fish, on which it feeds, as well as on frogs and lizards. The largest number of these birds that $I$ have known to occur in this vicinity at any one time, was five; they were observed for several days on the beach at Coney Island, and were extremely shy and vigilant, eluding all attempts to capture them. At the South it is abundant, and large numbers are shot for the value of its plumes, which are prized as ornaments. 


\section{F A M I L Y A N A T I N}

\section{DUICISS.}

\section{GENUS ANSER-BRISS.}

GOOSE.

[In this cluss of Birds, the bill is shorter than the head, rather higher than broad at the base; hoad small, compressed; neck long and slender; body full; feet shorr, stout, and central, which cuables them to walk with ease; wings long ; tail short, rounded.]

\section{ANSER CANADENSIS-LINN.}

CANADA GOOSE.

Canada Gonse, Anas Canadensis, Wils. Amer. Orn.

Anser Canadensis, Bonap. Syn.

Auser Cituadeusis, Canada Guose, Sw. \& Rich.

Canada Guo:c, Nutt. Man.

Canada Goose, Anser Canadensis, Aud. Orn. Biog.

Specific Character-Length of bill from the corner of the mouth to the end two inches and three sixteenths; length of tarsi two inches and seven-eighths; length from the point of the bill to the end of the rail about forty inches, wing eighteen; the head and greater portion of the neck black; cheeks and throat white. Adult with the head, greater part of the neck, primaries, rump and tail, black; back and wings brown, margined with paler brown; lrwer part of the neck and under plumage whitish-gray; flanks darker gray; cheeks and throat white, as are the upper and under tail coverts. The plumage of the female rather duller.

Late in autumn, especially when the wind is from the northeast, the Canada Geese are seen in our section of country, sailing high in the air, making their accustomed tour at that season. Impelled by Nature they quit their northern abode and hazard an escape from the artifices of man sooner than perish amid the icy barrens of the frozen regions. When migrating many flocks unite and form a vast column, each band having its chosen leader. They generally 
continue flying during the night, but occasionally alight and await the day. Before doing so, however, their experienced pioneers survey the space below and select a place favorable for food and safety. Sentinels are then appointed from among the ganders to sound the alarm should an enemy appear. I have seen them adopt the same precaution when sanding in large flocks by day. Those separate from the main body would move about with heads erect, ready to catch the first sign of intrusion; "after strutting their hour" would return to the main body, their places being immediately supplied. by others. I have often been disappointed by such a movement, supposing it to be a signal for flight, looked well to my gun, but after waiting a few moments in suspense, discovered it to be merely a change of guard.

The hoarse honking of the gander is so familiar to the inhabitants of our country, that it is impossible for them to arrive among us without making their visit known. All welcome their return; the once keen eye of the aged gunner again sparkles as he beholds their grand and. lofty flight. The firelock, that useful piece of furniture which ornaments all our farm-houses, is immediately brought into requisition, and the village store-keeper is industriously employed in answering the demand for "single B.'s." The report of guns reverberates through the country, but still these sagacious birds keep on their steady course; occasionally a single feather may be seen slowly descending to the earth, as if to inform the eager gunner of their nicely calculated distance, or perchance after the loud report of some well-mettled piece, a single bird may be seen leaving the flock, its death knell sounded by its more fortunate, but terrified companions.

But not so with the practised bay-gunner. On the return of the Geese his prospects brighten; he looks upon them as debtors returned to cancel a long-standing obligation; he wastes not his ammunition on space; he has watched their flight, and discovered their favorite sanding place ; the long-neglected decoys are placed in his skiff, and before daylight has appeared, he is pulling his way across the rough bay with glorious anticipations of profit. On gaining the desired point, he puts out his decoys, sinks a box in the sand, and there lies concealed. As they approach, his keen eye 
glances quickly over his trusty gun, and ere a moment elapses death is among them.

When wounded, they have the power of sinking themselves in the water, leaving their bill out. In this situation they will remain a considerable length of time. The dead body of a Goose, when lying on the water, will float two-thirds out. In stormy weather they fly low; when it is very foggy, they frequently become confused, and alight on the ground.

The Canada Geese remain with us until our bays are frozen, and return with the disappearance of ice in the spring; at this season their stay is short. Early in April they collect in large flocks, and almost simultaneously move off. Their food consists of sedge roots, marine plants, berries, and herbage of most kinds. In winter they are common on the lakes in the neighborhood of the lower Mississippi, where I was informed by the inhabitants that a few stragglers remain with them during summer.

This species is not the origin of the Domestic Goose, as is by some supposed, the genealogy of which it is said has been traced to the Bean Goose of Europe.

"The English of Hudson's Bay depend greatly on Geese of these and other kinds for their support, and in favorable years, kill three or four thousand, which they salt and barrel. Their arrival is impatiently attended; it is the harbinger of the spring, and the month named by the Indians the Goose Moon. They appear usually at our settlements in numbers about St. George's day, O.S., and fiy northward to nestle in security. They prefer islands to the continent, as farther from the haunts of men. Thus Marble Island was found in August to swarm with Swans, Geese, and Ducks, the old ones moulting, and the young at that time incapable of flying. The English send out their servants, as well as Indians, to shoot these birds on their passage. It is in vain to pursue them. They therefore form a row of huts, made of boughs, at musket shot distance from each other, and place them in a line across the vast marshes of the country. Each hovel, or, as they are called, 'stand,' is occupied by a single person. These attend the flight of the birds, and on their 
approach mimic their cackle so well, that the Geese will answer, and wheel and come near the stand. The sportsman keeps motionless and on his knees, with his gun cocked the whole time, and never fires till he has seen the eyes of the Geese. He fires as they are going from him-then picks up another gun that lies by him, and discharges that. The Geese which he has killed he sets upon sticks, as if alive, to decoy others-he also makes artificial birds for the same purpose. In a good dayfor they $\mathrm{fly}$ in very uncertain and unequal numbers, a single Indian will kill two hundred. Notwithstanding every species of Goose has a different call, yet the Indians are admirable in their imitation of every one."-Pennant's Arctic Zoolocy, as quoted by Bewick.

\section{ANSER HUTCHINSII.}

\section{HUTCHINS'S GOOSE.}

Anser Hutchinsii, Hutchins's Bernacle Goose, Sw. \& Rich. Hutchins's Goose, Auser Hutchinsii, Aud. Orn. Brog.

Specifir Character-Bill from the corner of the mouth to the end, one inch and nine-sixteenths; length of tarsi two inches and serensixteenths; head and upper part of the neck black; cheels white. Adult with the bill black; head and upper part of the neck glossy black; a white patch on the sides of the head and neck, similar to A. Canadensis; upper parts brownish-gray, the feathers margined with paler; lower parts pale grayish-brown, margined with yellowish-brown; abdomen and lower tail coverts white; tail of sixteen feathers, of a deep brown color, as are the primary quills; feet and claws black. Langih twenty-seven inches, wing sixteen.

At the eastern extremity of Long Island, this species is not uncommon. At Montauk it is known by the name of "Miud Goose," and is frequently observed in company with the preceding species, to which, in the general color of the plumage, it bears a strong re- 
semblance. In size it is much smaller, though larger than the "Brant," exceeding that species about three inches, and having the white patch on the sides of the head similar to the Canada Goose.

On the south shore of Long. Island it is not known to the gunners, though $\mathrm{I}$ have no doubt that it is frequently procured there, and from the close resemblance it bears in its general markings to the Canada Goose, is considered a variety of that species. At some seasons it has been known to be quite abundant on the coast of Massachusetts, in the vicinity of Boston, and it has been shot on the Chesapeake.

Dr. Richardson states that it is well known at Hudson's Bay, and that it is always found on the sea coast, feeding on marine plants, and the molusca which adhere to them, whence its flesh derives a strong fishy taste.

\section{ANSER BERNICLA-LINN.}

\section{BRENT GOOSE.}

Brant, Anas Bernicla, Wils. Amer. Orn.

Auser Bernicla, Bunip. Syn.

Anter Bomelu. Breul (Biose, Sw. \& Rich.

Brant or Brent Guose, Nutt Mian.

Bacul Givee, Auser Betulcla, Aud. Orm. Biog.

Specific Character-Bill black; head and neck all romd black; a patch on the sides of the neck white: upper parts brownish-gray - the feathers margined with light grayish-brown; quills and primary coverts grayish-black; fore part of breast, light brownish. gray, the feathers terminally margined with grayish-rihite; abdomen and lower tail corerts white; sides gray, the feathers rather broadly tipped with white. Lenoth two feet, wing fourteen inches and a half. Female rather smaller.

The Brent Goose, or the "Brant," as it is more familiarly called, makes its appearance among us about the fifteenth of October. Mr. 
Audubon found it breeding at Labrador, but was prevented from securing its eggs in consequence of the great depth of the moss on which it was nesting.

In the spring and autumn it is very numerous on our coast, exceeding in number the Canada Geese and Dusky Ducks. Its manner of flying is different from that of the Canada Goose-moving in more compact bodies, less rapidly, and withont seeming to have a chosen leader-that marked characteristic in the flight of the latter. While in otr bays it appears inactive, seldom taking to wing unless disturbed by a passing boat, or the near report of a gun.

The Brent rises slowly, and when on the wing, moves sluggishly for a short distance, and if not attracted by a distant flock, frequently returns to the place it had left. Its food consists of a marine plant, (Zostera marina,) commonly called "eel grass." At low water it is seen industriously at work, tearing up its favorite plant. After the tide has risen to such a height as to compel it to relinquish its vocation, it is seen drifting with the current, feeding sumptuously on the fruits of its labor.

I have examined a number of these birds, and in no instance have I found fish in them.

The Brent Geese are very fond of sanding, and resort to the bars for that purpose, at which places they are killed in great numbers by the gunners, who secrete themselves in excavations made in the sand. The bar known as "Fire Island Bar," on the south side of Long Island, is a celebrated place for procuring them. It is included in the Nicol's Patent, and rented to two brother's by the name of Alliby at $\$ 120$ per annum. I am informed that these men send to the New York market annually several hundred dollars' worth of birds, the larger proportion of which is Brent.

This species, when passing over our bays, avoids as much as possible the points and "kussicks,"* which makes it very difficult to be obtained, unless procured in the manner just mentioned, or by

" "Kussick," "hassick," or "thatch,"-local terms used by gunners, signifying large tussocks of tall grass that occur in the bays. 
shooting from "batteries" anchored in the shallow parts of the bay These batteries are constructed in the following manner-by making a box six feet long, two feet and a half wide, one foot deep, with the sides and ends shelving, on which sand is placed to imitate a bar, as well as to assist in sinking the "machine," as it is calledthat its uppermost edges may be about even with the surface of the water. The gunner, by lying in the box on his back, is perfectly concealed, and having a large number of decoys around the batiery, the deception is so perfect, that the birds often approach so near, as to give him an opportunity of discharging with effect two double barrelled guns into a flock. Great havoc is made in this way, particularly among young birds. This mode of shooting requires two persons-one to shoot from the battery, the other to attend with a boat, to collect the dead birds, and drive up flocks sitting on the bay. It is, however, objected to by many, they supposing it to be too destructive, as well as the means of driving from the bay those which escape. The Brent, especially, is a wanderer, seldom remaining longer than a few days in one place, under any circumstanceswhich induces many to suppose that they have a right to secure them in any way that fancy dictates.

In 1838 a law was passed in this State, prohibiting the use of batteries. For a short time it was respected-but the gunners who depend on Water Fowl shcoting for a great part of their living, considered it such an invasion of their rights, that they defied it; at first shooting with masks, at the same time threatening to shoot the in. former, should one be found. They finally laid aside their masks, and the law became a dead letter, and has since been repealed. A far greater evil is that of firing from boats, while sailing on their feeding grounds. After having been shot at in this way, I have seen them rise high in the air, and steer for the sea. I think it would be as well if the gunners generally would agree to abandon this unsportsmanlike practice.

The Brant never dives for its food; but when wounded, it is not unusual for it to attempt escape by diving. As it seldom passes thirty or forty yards under the water, it is generally secured. With the lovers of Water Fowl the Brant is highly esteemed. Even the adult birds are tender and juicy, and free from a fishy flavor, but at 
times, from the nature of its food, its flesh acquires a sedgy taste. It is considered superior for the table late in the Spring. The epicure well knows the merits of the "May Brant."

In the plumage, there are no markings by which the sex can be distinguished. Many undertalie to determine it by the white markings on the sides of the neck, supposing that character to be more fully developed on the neck of the male; but this cannot be depended upon. I have frequently selected them by this supposed distinction, and on dissection the male and female organs have appeared without reference to such character.

Their unwillingness to give up their wandering habits, makes it difficult to domesticate them. I have frequently tried it with young: birds, having taken the precaution to cut off a joint from one of their wings, thus rendering them incapable of flying; still they would wander to the creeks that lead to the bay, and doubtless liave fallen easy game to some passing sportsman. With a good deal of attention, particularly when associated with Canada Geese that have been domesticated, its native propensities are more easily subdued; but in the domestic state hare never been known to breed.

'The average weight of the Brant is four pounds. The adult can be distinguished to a certainty from the young, by its wingswhich are entirely black, while those of the latter are broadly tipped with white. As soon as the ice begins to form in our bays, it retires southward. Returning in April, it continues its visit until late in May, when they assemble at the "great nursery" at the North.

\section{ANSER ALBIFRONS-BECHST.}

\section{WHITE-FRONTED GOOSE.}

Anser albifrons, Bonap. Syn.

Anecr albifroms. Letughueg Goose, Siw. \& Rich.

Whitc-lronced Goost, Nutt. Man.

White-frunted Guoze, Auscr allifrons, Acd. Orn. Biog.

Specific Character-Head and neck greyish-brown; at the base of the upper mandable, a white band. Adult with the bill carmine red; with the unguis white; head and neck grayish-brown; 
a white band, margined behind with blackish brown, on the anterior part of the forehead, along the bill; general color of back, deep gray, the feathers of its fore part biondly tipped with grayish brown -the rest with grayish white; hind part of back deen gray; wings grayish brown; toward the edge, ash gray-as are the primary coverts, and outer webs of the primaries; the rest of the primaries and secondaries, grayish black, the latter with a narrow edge of grayish white--the former edged and tipped with white; breast, abdomen, lower tail coverts, sides of rump, and upper tail coverts, white; the breast and sides patched with brownish black-on the latter intermixed with grayish brown feathers; tail rounded, feet orange, claws white; length, twenty-seven and a half inches, wing, fourteen and a half inches.

On the coast of Long Island this Goose is exceedingly rare. The cabinet of the Lyceum of Natural History, New-York, contains a specimen that was shot at Babylon. According to Mr. Audubon, " it passes through the interior of the Southern and Western States during winter, as well as along the coast from Massachusetts to Texas ; and is said to pass through the interior of the fur countries in large flocks to its breeding places, which are the woody districts to the north of the seventy-seventh parallel, and also the islands of the Arctic Sea."

\section{ANSER HYPERBOREUS-GMEL.}

\section{SNOW GOOSE.}

Snow Guose, Anas hyperboreus, Wilson.

Anser hyperhorens, Bunap.

Snow Guose. Nuttali.

Aneer hyperboreus, Snow Gonse, Sw. \& Rich.

Sno.v Guose, Anser hyperborcus, Aud.

Specific Characler-Bill and feet carmine ; plumage pure white; fore part of head tinged with yellowish red; primaries brownish gray-toward the end, blackish brown. Length thirty-one inches and three quarters, wing fifteen. Female messures about six inches less. Young with the head and upper part of the neck and wing coverts, grayish white; lower part of neck, fore part of kack, fore 
part of breast and sides, blackish gray; hind part of back, and upper tail coverts, ash gray; abdomen grayish white-secondaries margined with the same; bill flesh color.

With us, the occurrence of this bird is not frequent. Occasionally the young are seen exposed for sale in the New-York marliets, though rarely the adult. In some seasons, small parties are seen on the South Bay, and now and then stragglers are seen nying in company with the Canada Geese. The whiteness of their plumagc renders them very conspicuous, and when opportunity offers, are always singled out by the gunners.

"The Snow Gnose breeds in the barren grounds of Arctic America in great numbers. It feeds on rushes and insects, and in Autumn on berries. When well fed, it is a very excellent bird-far superior to the Canada Goose, both in juicincss and flaror."

"l'he Snow Geese " alie their appearance in Spring, a few days later than the Canada Geese, and pass in large flocks both through the interior and on the sea coast. '-Favna beneali Americana, part II. page 467 .

\section{GENUS CYGNUS-MEYER.}

SIVAN

[Bill Innger than the bead, bigher than broad, at ihe lase depressed, and a little widencel loward the end; rounicd, upper mandbi.r, with the rtosal line, sloping; lower mandible fattened, with the angle very long, and rather uarrow; rostrils, laced near the ridge; head of moderate s'ze, oblurg compresect ; reck ratrumcly lorig and slender; hody very large, complace, depressed ; fect slort, stout-placed a litte behind the centre of the body; tarsi short; wings long; lrosd; tail icry short, graduatcd ]

\section{CYGNUS AMERICANUS-SHARPLESS.}

\section{AMERICAN SWAN.}

American Wild Swan, Cygnus Americanus, Sharp'ess, $A$ mer.

Jour. of S ience and Aris.

Amctican Swan, Cyguus Americanus, Aud. Orn. Biog.

Specific Character--Plumage pure white; bill and feet black. Length of the specimen before us, 4 feet, wing $21 \frac{1}{2}$ inches.

The American Swan passes the season of reproduction at the dreary regions of the far North. At the approach of winter, it re. 
turns to the warmer parts of the continent. In its migratory course, it is frequently met with in the Midrlle Atlantic Districts, and is quite common on the Chesapeake Bxy during winter. Two species arc known to inbabit this continent-the present, [Cyguns Americanus, ] and the Trumpeter Sivan, [Cyguns B:ıcinato:.] 'The latter differs from the former by being superior in size, as well as in its anatomical structure. 'Thiese species were separated by Mr. Sharpless, who deciled this point from his knowled ge of comparative anatorny.

This elegant bird is frequently domesticatel, and by its spotless plumage, and graceful movernents when oa its native element, fails not to attract the attention of the pesser ty. The young are highly estecmed for the table.

The present species is the oaly one which I have ever lnown to be seen in this ricinity.

\section{GENUS $\triangle$ NAS-LINN.}

\section{FRESH WATER DUCK.}

[Bill higher than rroad at the hase, widening towart the end, and ahout the sane lengh as libe head - the "iper mandule with a slight nail at the end ; neck rather long--body ful!--wings inoderate pointed: feet short, stout, and placed behind the centre of the hody - walks with a waduling gait-lind toe furnished with a narrow membranc.]

\section{ANAS BOSCHAS-LINN.}

\section{MIAIIAARD.}

Mallard, Anas Busclias, Wils. Amer. Orn.

Anas Buschas, Busap. Sinn.

Anas (Buschas) dlo nestica. Mallard. Siv. \& Rich.

M.lllard Durk, Anas dousestıca, Nutt. Mian.

Maliard, Anas Buechas, Aud. Orn. Biug.

Specific Characler-Speculum bright purple, reflecting gieen, bordered witn black; secondaries broadly tipped with white; secondary coverts toward their ends white, broadly tipped with black. Adult male with the entire head and upjer patt of the neck bright green, with a few touches of reddish-brown passing from the fo:ehead on the occiput; middle of the neck with a white ring; the 
lower part of the neck and breast reddish-brown, approaching to chocolate ; fore part of the back light browr, rrst of the back darker; rump black; upper tail coverts greenish-black; upper parts of the wings brown, intermixed with gray; breast, sides, flinks, and abdomen, gray, transversely barred with dusky ; bill greenish-yellow; feet reddish-orange; tail rounded, consisting of sixteen pointed feathers, nearly white; speculum violet. Length two feet, wing eleven inches.

Female smaller than the male; speculum less brilliant; general plumage brown; head and neck streaked with dusky; the feathers on the back and fanks margined with white, with a central spot of brown on the outer wets; bill black, changing to orange at the extremity.

'I'he Mallard is unirersally known as the origin of the common Domestic Duck. In its wild state, it is inferior in size to those fed by the hand of man, but far excels in beauty. To those unacgrainted with the distinguishing marks of the wild and domestic birds, I will here point out a single feature which may always be depended upon - lie feet of the former, from being constantly in t'e water, or on swampy grounds, are soft and pliable, while those of the latter, from walking orer the gravel, become luard and much bioader. Though not a frequent visiter on the sea coast, occasiona.' y a pair, or more generally a single individual, is seen passing over our wide bays, as if tired of its solitary journey; it unites with others of its tribe, when the lieen eye of the calculating gunner readily singles it out from the Dusky Ducks.

Like all other species, the Mallard takes its abode where the choice of food is most reacily obtained. It is met with in various parts of the United States, as well as in Europe, giving preference to the fresh water streams, lakes and ponds, where it feeds sumptuously on a variety of nutritious plants, as in general the fine condition of its body testifies.

Like the Dusky Duck, when pursued by the sportsman, it becomes s'y, and feeds at night, dozing a way the day out of gun-shot from the shore.

Early in the month of July, 1837, while hunting over the meadows for smaller game, I came upon a pair of Mallard Ducks, mo. 
ving slowly down the celebrated "Brick-house Creek." The thought occurred to me that they were a pair of tame Ducks, that had become tired of the monotory of domestic life, and had determined on pushing their fortunes in the wide bay. As I advanced they took wing, which undeceived me, and I brought thern down. They proved to be an adult male and female. From this circumstance I was led to suppose that they had bred in the neighborhood. I made diligent search, and offered a bounty sufficient to induce others to search with me-but neither nest nor young could be found Probably when migrating, they were shot at, and so badly wounded as to be unable to perform their fatiguing journey, perhars miles apart, and perchance only found companions in each other a short time before I shot them.

In North Carolina this species is abundant, and in the habit of frequenting the rice.fields, on which plant it is fond of feeding.When the planter wishes a repast of Wild Ducks, he orders a field to be overflowed, and sends a servant to procure the desired game. After waiting a favorable opportunity, it is not unusual for him to return with from seven to ten of these highly esteemed birds, procured at a single discharge of his well-loaded gun. In the bayous on the lower Mississippi, they are common. In Alabama-where they are called "English Ducks" - I found them more numerous. When surprised they move off in pairs. 'Their voice resembles that of the domestic Duck.

\section{ANAS OBSCURA-GMEL.}

\section{DUSKY DUCK.}

Dusky Duck, Anas obscura, Wils. Amer Orn.

A nas obscura, Bonap. Syn.

Duskv Duck, Anas obscura, Nutt Man.

Dusky Duck, Anas obscuca, Aud. Orn. Biog.

Specific Character-General plumage dusky; speculum green, refecting purple, bordered with black; secondaries tipped with white. Adult with the forehead, crown, occiput, and middle space on the hind neck brownish-black, the feathers slightly margined 
with grayish-brown; cheeks, loral space, and sides of the neck, dusky gray, streaked with black; throat reddish-brown; gencral plumage dusky, ligt!ter beneath; under wing corerts white; speculum brilliant green; bill yellowish; feet reddish-orange. Female rather smaller; plumage lighter, speculum less brilliant. Length of male about two feet, wing eleven inches.

'I'his species, better known to our gunners by the name of "Black Duck," is peculiar to the American continent. In its habits it is only partially migratory, although on the island in the summer they are seldom seen, concealing themselves in the tall grass that grows luxuriantly where they take up their abode. Ihis may to accounted for by their subsisting on roots and small shell-fssh, so abundant on the salt marshes, that during the seascn of incubaticn and rearing their young, they are not obliged to leave their secluded residences in search of food. In selecting their summer residences, they so studiously avoid intrusion from man, that their nests are seldom met with. A friend of mine residing on the south side of Long Island, had, however the good fortune on the 19th of May, 1810 , to fiad two nests, mude of corrse materials. One contained seren, the other nine eggs, of a dullish white color. 'They werc placed under two hens. In a short time four of the former and seven of the latter brought forth ducklings. They soon discorered that their feet were intended $f(r$ other rurgosc sthan scratcling for food. On entering the water, their foster-mothers would cxpress their astonishment by a loud "cackle," moving rapidly along the bank of the creek, their eyes glistening with evident signs of fear for the safety of their adopted brood. They soon forgot these kindly admonitions, by making frequent excursions to the bay, giving no evidence of a wish to return, as the trouble they gave in securing them will testify. He was at last obliged to confine them in a close pen. In this situation, they appeared rery uneasy. While thus confined, they refused corn* and all sorts of grain, but devoured clams, or any kind of shell fish, greedily. In this way he liept them until they were several weeks old, when he parted with thern to a friend who I am informed succeeded in domesticating them.

*In their wild state, they are frequently baited with corn, and other sorts of 
At the season of the year when their numbers make it an object to pursue them, they may be seen shortly after daylight leaving their feeding grounds and steering for the sea, returning at dusk for the purpose of feeding. The most successful manner of procuring this species is in a manner the gunners term "dusking." This mode of shooting is practised on moonlight evenings, by lying concealed near the place which they are in the habit of frequenting. Perfect silence must be observed-at the slightest noise, they are off. Their remarkable shyness leads many of the gunners to suppose, that when flying toward them from the leeward, the Dusliy Duck can scent them. To prevent this, it is not an unusual practice to burn tow. Large numbers are often lislled by dusking. Miess:s. James Smith and John Verity, two celebrated gunners, residing at South Oyster Buy, informed me that while dusking one cvening they killed ninety-nine, and had oprortunities of killing many more; but their stock of ammunition having become exhausted; of course they were suffered to escape. I have frequently practised dusling with far less success.

In small parties they kieep moving about all night. When wounded, they often escape by diving. When fairly shot, they fly a great distance before falling. I have frequently supposed I had missed my mark, from the rapid manner in which they moved after having been fairly shot-and having watched them, I have seen them strike the water at least half a mile from where they receired the fatal charge. In stormy or very severe weather, they seldom venture out to sea-at such times they fly low, afiording a gcod opportunity to capture them.

During winter, should it be a mild one, food is then easily ottained, and they get in fine condition, and are highly esteemed. 'l'hey often appear in our market early in September, but are more numerous in Norember, and early in the Spring. All other species of water-fowl rise against the wind. When surprised, the Dusky Duck will spring up in any direction, continuing to ascend until it is out of the reach of the strongest powder and the best of guns. I have often been amused on seeing them pass over a kussick, when, as if suddenly remembering having been shot at from a similar 
place, they would dexterously rise, as if expecting to hear the lead whistle around them.

There is no great difference in the male and the female. The former is rather larger, the plumage darker, and the beauty spot on the wing brighter. Their voice in general resembles the domestic Duck, but at times they have been heard to give utterance to a loud whistling note. When at Niagara, I was informed that on the 16th of October, 1840, eighty-three Dusky Ducks were litled by flying into the Falls. 'They were piclied up by the toatmen in attendance at the ferry, a shout distance below the Falls. I was told that in foggy weather, this is not an unusual occurrence. In the Museum at that place, a number of birds were pointed out to me, that lost their lives by alighting a short distance from the precipice, and before they could rise, were carried over and lilled.

\section{ANAS STREPERA-LINN.}

\section{GADWALL.}

Anas strepera, Wils. Aincr. Orn.

Anas strepera, Bonap. Syn.

Allas (Chauliudus) strepera, Gadwall, Siv. \& Rich.

Gddwall, or Gray Duck, Nutt. Man.

Gadwa!l Uuck, Ánas sircpera, Aud. Orn. Biog.

Specific Character-Speculum white; secondary coverts black; upper wing coverts chestnut red; general plumage dusky gray, waved with white; abdomen whie. Adult with the bill bluishblack; hearl and upper part of the neck gray, streaked with dusky -darkest on the upper part of the head, as well as the middle space on the hind neck; lower neck, upper part of the breast and fore part of the back blackish-brown, the feathers marked with semicircular bands of white-more distinctly on the fore part of the neck and upper part of the breast; sides of the body pencilled with grayish-white and dusky; lower part of the breast and abdomen white, the latter barred with dusky toward the vent; lower and upper tail coverts and sides of the rump greenish-black; tail grayishbrown, margined with white; hind part of the back dark brown, 
faintly barred with white; primaries brown; secondaries grayishbrown, tipped with white; middle covelts reddish-brown; a few of the outer secondaries broadly margined with greenish-black; in. ner scapulars brown, broadly margined with dull yellowish-brown; outer undulated with dark brown and yellowish-white; feet dull orange. Female two inches shorter, and about four inches less in extent. Length twenty one inches and a half, wing eleven.

In this vicinity, the Gadwall is quite rare-in the Southern States it is more common. Wilson mentions haring met with it at the Seneca Falls about the twentieth of October-at Louisville on the Ohio -and the Big-Bone Lick in Kentucky, in February-these specimens were males.

"The Gadwall is an inhabitant of both continents. In England, it is rare, but common on the coasts of France, Switzerland, and Sardinia. Breeds in the woody districts of the remote northern Fur countries of Canada. In the north of Europe, it inhabits the vast rushy marshes-and in Holland, where this species is common, it associates with the Mallard." My first acquaintance with this bird was in 1834, while pursuing my favorite amusement of water fowl shooting in the celebrated South Bay. It was flying alone, seemingly wandering about as if in search of companions. It passed and repassed several times outside of my decoys, without approach. ing within gun-shot, but sufficiently near to excite in me a desire for having a better opportunity to examine it. I concealed myself with great care, hoping that it would approach within shooting distance, as I was induced to believe that it would, from the desire it exhibited to join the motly flock which my "decoys" represented; but as it advanced, it appeared to see that all was not right, and at the moment when my hopes were the brightest, it quickly changed its course, and alighted on a marsh about a half a mile from me. I gave quick pursuit, and after wading through the tall grass and mud, discovered it sitting on a bog, pluming and dressing its feathers, unconscious of its impending fate. Its perfectly neat appearance so engaged my attention, that I forgot that a gun was in my possession, until it took to wing, when the desire to obtain it returned, and I brought it down. On taking it up, although proud of this 
valuable acquisition to my collection, I could not forbear feeling that Nature had been robbed of one of her greatest ornaments.

I have since killed a few along the south shore of Long Island. It is very shy, seldom obeys the decoys, and is exceedingly difficult to approach, unless the gunner advances, as opportunity offers, under cover of the reeds and rushes. At Egg Harbor a few are seen almost every spring and autumn, and are there known by the name of "Welsh Drake" or "German Duck." The Gadwall is one of the most active of its tribe; it flies swiftly, and is an excellent diver. The last individual which I have met with, I observed on "East Neck Creek," Huntington South. It was swimming down the stream, a short distance from the bank; and while I was in the act of raising my gun to fire, it took alarm, and instantly passed out of sight. As it did not appear again, I concluded that it swam under the water to the bank, and concealed itself among the rushes. All the traits of character that I have had an opportunity of observing in this bird, prores it to be of an exceedingly timid disposition. Its choice of food I cannot particularize, but from the superior quality of its flesh, I am inclined to the opinion that it subsists chiefly on vegetable matter.

\section{ANAS AMERICANA-GMEL.}

\section{AMERICAN WIDGEON.}

American Widgeon, Anas Americana, Wils. Amer. Orm.

Anas Americana, Bonap. Syn.

American Widgeon, Sw. \& Rich.

American Widgeon, Anas Americana, Nutt. Man.

American Widgeon, Anas Americana, Aud. Orn. Biog.

Specific Character-Bill short, the color light grayish-blue ; spec. ulum green, banded with black; under wing coverts white.Adult male with the loral space, sides of the head below the eye, upper part of the neek and throat brownish-white, spotted with black; a broad band of white, commencing at the base of the upper mandible, passing over the crown; behind the eye, a broad band of bright green, extending backwards on the hind neck about 
three inches; the feathers on the nape rather long; lower neck and sides of the breast, with a portion of the upper part of the breast, reddish-brown; rest of the lower parts white, excepting a patch of black at the base of the tail ; under tail-coverts same color ; flanks brown, barred with dusky; tail grayish-brown, tipped with white; two middle feathers darker and longest; upper tail-coverts white, barred with dusky; lower part of the hind-neck, and fore part of the back undulated with brownish and light brownish-red, hind part undulated with grayish-white; primaries brown; outer webs of inner secondaries black, margined with whitc-inner webs grayish brown; secondary coverts white, tipped with black; speculum brilliant green, formed by the middle secondaries. Length twenty. one inches, wing ten and a half. Female smaller, plumage duller, without the green markings.

This species, nearly allied to the European Widgeon, passes the summer in the dreary North, where it breeds. In this vicinity I have never known it to be numerous-in the Southern States it is more abundant. During the Spring and Autumn it is distributed throughout the Union, visiting the interior as well as the sea-coast. It subsists chiefly on vegetable diet, and when in good condition is prized as game. The W'idgeon, or "Bald-pate " as it is sometimes called, is said to be great annoyance to the "Canvass-back." The latter, when diving for food is frequently attended by the former. "The instant it rises, the Widgeon seizes the delicate morsel, and flies off with its prize."

\section{ANAS PENELOPE-LINN.}

\section{WIDGEON.}

Le Canard siffleur, Buffon.

Anas Penelope Wilgeon, Bewick's British Birds.

Anas Penelope Widgeon, Lawrence, N. Y. L, c. N. H.

Specific Character-Bill along the gap one inch and eleven-sixteentlis, higher at the base than A. Americana, and the black bordering wanting; point of bill punctured; whole under covering of wing ash-gray. 
"This bird weighs generally about twenty-three ounces, and measures nearly twenty incles in length and two feet in breadth. The bill is an inch and a half long, narrower and serrated on the inner edges; the upper mandible is of a dark lead color, tipped with black. The crown of the head, which is very high and narrow, is of a cream color, with a srnall spot of the same under each eye, the rest of the head, the neck and the brcast are bright rufous chestnut, obscurely freckled on the head with black spots, and darkest on the chin and throat, which are tinged with a virous color; a band, composed of beautifully waved or indented with narrow ash-brown and white lines, separates the breast and neck; the back and scapulars are marked with similar feathers, as are also the sides of the body under the wings, even as low as the thighs, but there they are paler; the belly, to the vent, is white; the ridge of the wing and adjoining coverts, are dusky ash-brown; the greater coverts brown, edged with white, in some specimens wholly white, and tipped with black, which forms an upper border of the changeable green heauty-spot of the wings, which is also bordered on the uncler side by another stripe, formed by the deep velvet black tips of the secondary quills; the exterior webs of the adjoining quills are white, and those next the back, which are very long, are of a deep brown-in some specimens dcep black-edged with yellowish-white; the greater quills are brown; the vent and upper tail coverts black; the tail, which consists of fourteen feathers, is of a hoary brownish ash, edged with yellowish white; the two middle ones are sharp pointed, darker and longer than the rest ; the legs and foes are of a dirty lead color, faintly tinged with green, the middle of the webs and nail black. The female is brown, the middle of the feuthers decpest; the fore part of the neck abd breast paler, scapulars dark brown, with paler edges; wings and belly as in the male."-Bewıck's Britrsh Birds.

An individual of this species, shot in the Bay of Long Island, svas procured by George N. Lawrence, Esq., from whom I received the following communication: 
New York, Dec. 3, 184 2.

"I this morning obtained a Widgeon in Fulton Market, shot on Long Island, which I recognised as belonging to the European species. It was, unfortunately, picked, excepting the head and upper part of the neck and wings. On comparison with an authenticated specimen of the European species, (Anas Penelope) I feel confirmed in my opinion, and it is, I believe, the first instance of its occurring with us. It differs from $A$. Americana in the coloring of the head and neck, and much also in the sliape of the bill, which is much higher at the base, and without the black line where it joins the head-the nail black, with minute punctures. The head rises gradually from the bill-not so abruptly as in A. Americana. The frontal feathers extend on the bill a quarter of an inch, forming an acute angle, which is not the case in ours. Crown reddishcream color; other parts of the head and the neck bright rufous, plainly sprinkled with small black spots, more numerous adjoin. ing the bill; throat of a dark, rich, vinous color, almost black; crest small, and the green color on the sides of the head confined to the immediate vicinity of the eye; under wing-coverts ash-gray, those of ours being white.

"J. P. Giratd, JR."

"Geo. N. Lawrence.

This being the first instance of A. Penelope's occurring, at least within the bounds of the United States, (and I am not aware that it las ever before been observed in North America) no doubt some will be unwilling to give it a place in our Fauna. But if we refuse to admit it on account of its extreme rarity, we shall be oblig. ed to crase others from our list of North American birds. We do not mean to say that every bird seen at large should be considered indigenous to our country, as we frequently find species that we know are peculiar to Europe, as for instance the Ruff, IW heat-ear, Sky Lark, and other roreign species, have been found on Long Island-these we know must have been brought over as a matter of speculation, presents to friends residing here, or favorite pets of persons emigrating to this country, which have cscaped from their cages. But we cannot conceive what inducement could offer to 
persons visiting this country to bring with them a live Widgeon, as there is nothing to admire in its voice, or any thing particularly elegant in its plumage, or delicious in the flavor of its flesh. Thus, as a matter of profit or pleasure, it would not compensate one for the trouble.

\section{ANAS ACU'TA-LINN.}

\section{PINTAIL, DUCK.}

Pintall Duck, Anas acuta, Wils. Amer. Orn.

Anas acuta, Bonap. Syn.

Anas caudacuta, Puitail Duck, Sw. \& Rich.

Pintall ur Winter Duck, Anas acula, Null. Man.

Piutail Duck, Auas acuta, Aud. Orn. Biog.

Specific Character-Bill long and narrow, lead color, at the tip a spot of black, at the corner of the mouth a spot of similar color; neck long and slender; speculum bright purple, with reflecting deep green, bordered with black; the feathers broadly tipped with white; tail long and pointed. Adult male with head, cheeks, throat, upper part of the neck in front and sides, dark brown; a band of light purple behind the eye, extending about three inches on the sides of the neck-on the hind neck a band of black, with green reflections, fading as it extends on the back-a band of white com. mencing between the two former, passing down the neck on the lower part of the fore-neck. Breast and fore part of the abdomen white, tinged with pale yellow-hind part of the ablomen and vent grayish-white, tinged with yellow, and marked with undu. lating lines of brown or dusky. At the base of the tail a patch of black-under tail-coverts black, margined with whitish-two mid. dle feathers black, with green reflections, narrow, and about three inches longer than the rest, which are rather long and taperingupper tail-coverts ash-gray, margined with yellowish white, with a central streak of dusky. Rump grayish-brown, marked with undulating lines of white-sides of the rump cream-colorsides of the body, back, and sides of the breast, marked with undulating lines of black and white. Primaries brown -shafts brownish.white, darker at their tips-secondaries and 
scapulars black, with green reflections, the former margined with gray, which is the color of the greater part of the outer web, the latter margined with white. Speculum bright purple, with splendid green reflections edged with black, the feathers broadly tipped with white. Length twenty-nine inches, wing eleven. Female with the upper part of the head and hind neck dark brown. streaked with dusky-sides of the throat and fore-neck lighter-a few touches of rust color on the chin and on the base of the bill. Upper plumage brown, the feathers margined and tipped with brownish-white. Lower plumage brownish-white, mottled with brown. Speculum less extensive, and without the lengthened tail feathers so conspicuous in the male.

This beautiful species is well known to our gunners by the name of "Sprig," or "Spreet-tail." In passing to and from their breeding place at the far North, they are distributed throughout the Union, visiting the interior as well as the sea coast. Although shy and timid, it is often brought within reach of the fowler's gun by the treacherous decoys; and when surprised by the gunner's rising to fire, they crowd so close together, presenting what is called a "doublet," so that many are seen to fall from a single discharge.

Mr. Townsend speaks of it being very abundant on the Columbia River.* He mentions that he and an Indian chief killed twenty six Pintails at a simultaneous discharge of their guns. It does not dive for food, but when wounded sometimes makes an effort to escape by diving. As it rises to the surface it endeavors to conceal itself by remaining under the bow of the boat-and if near a marsh, it will skulk in the grass, so well hiding itself as often to escape detection.

The young and females are mistaken by many persons for a dis. tinct speeies, which they call Gray Duck. In clear weather, it is seen high in the air, flying close together, and rapidly. When on the wing it is easily distinguished from other species by the pecu. liar movement of its wings.

* See Townsend' Narrative of a Journey across the Rocky Monntains. 


\section{ANAS SPONSA-LINN.}

SUMMEIR DUCK.

Summer Duck, or Wond Duck. Anas sporsa. Sw \& Rich.

Dendronessa sponsa, Summer Duck, Siw. \& liich.

Sunmer or Woud Duck, Anas sponsa, Nutt. Man.

liood Duck, Anas sponsa, Aud. Urn. Biog.

Specific Character-The pendant crest, the throat, upper portion of the fore neck and bands on the sides of the neck white, with the speculum blue, glossed with green and tipped with white. Adult male with the bill bright red at the base, the sides yellow, between the nostrils a black spot reaching nearly to the black, hooked nail, the head is furnished with long silken feathers, which fall gracefully over the hind neck, in certain lights exhibiting all the colors of the rainbow-a narrow white line from the base of the upper mandible, passing over the eye-a broader band of the same color behind the eye, both bands mingling with the long feathers on the occiput -throat and upper portion of the fore-neck, pure white, a band of the same color inclining toward the eye-a similar band on the sides of the neck, nearly meeting on the nape-lower portion of the neck reddish-purple, the fore part marked with triangular spots of white -breast and abdomen dull white-sides of the body yellowish-gray, undulated with black, the feathers toward the ends marked with a broad band of black, succeeded by a band of white-tips black.Tail and upper tail-coverts greenish-black-lower tail-coverts brown - sides of the rump dull reddish-purple-rump, back, and middle portion of the hind-neck, dark reddish-brown, tinged with green-a broad white band before the wings, terminating with black-lesser wing-coverts and primaries brown, most of the latter with a portion of their outer webs silvery white-the inner webs glossed with green toward the ends-secondaries tipped with white-their webs blue, glossed with green-the inner webs brown-their crowns violet blue-secondaries black.

Female, upper part of the head dusky, glossed with green; sides of the head, upper portion of the sides of the neck, with the nape, grayish-brown; a white patch behind the eye; throat white, the 
bands on the sides of the neck faintly developed; fore part and sides of the neck, with the sides of the boty, yellowish-brown, marked with grayish-brown; breast and abdomen white, the former spotted with brown; lower tail-coverts grayish-white, mottled with brown. Tail and upper tail coverts, dark brown, glossed with gुreen; rump, back, and hind-neck dark brown, glossel with green and purple; bill disky; feet dull green. The crest less than that of the male, and plain dull brown. Length twenty inches, wing eight inches and a half.

This splendid American species is more generally known by the name of Wood Duck It is common in most parts of the United States, and according to Wilson, is found in Mexico and many of the West India Islands. It is seldom seen on the open bays, giving preference to the still ponds and shady creeks, where it finds an abundant supply of its furorite food, which consists of insects, seeds, and plants. In its stomx I have frequently found acorns.

It is called Summer Duck from remaining with us throughout the summer. Often when following those beantiful and rapid strears that greatly embellish our country, in pursuit of the angler's beau ileal of sport, have I inet with this gaily-attired Duck. $\Lambda$ s if proud of its unrivalled beauty, it would slowly rise and perform a circuit in the air, scemingly to give the admiring beholder an opportunity of witnessing the gem of its tribe.

This species, Nature has profusely embellished. In it she has united most of the vivid hues, brilliant spots, and bright lines bestowed upon all the others, as if to give a specimen of her inimitable style of coloring. It is calleil "Wool Duck," from the circumstance of their selecting lollow trees to breed in. Its beautiful plumage is so much admired, that it is not unusual for persons residing in the country to invite it near their divellings by placing boxes for it to breed in, as it is considered a great ornament to a gen. tleman's country seat.

They keep in small parties, generally moving about in pairs. They are sometimes taken in nets. I am informed that a Mr. Brown, residing in Saratoga Connty, about 30 miles west of Albany, sends a large number to the New-York Market annually, taken in this way. In plumage it is not unlike the Mandarin Duck of China. 


\section{ANAS CAROLINENSIS-STEPH.}

\section{AMERICAN GREEN-WINGED TEAL.}

Green-Winged Teal, Anas crecca, Wils.

Anas creceit, Bonap.

Anerican T'eal, Anas crecea, Nult.

Anas crecea, Green. Wu.ged Teal, Sw. \& Rich.

Green-Winged 'T'cal, Auas creera, Aud.

Specific Characler-Bill black, short and narrow, the outer wets of the first five secondaries black, tipped with white, the next five plain rich green, forming the speculum, secondary corerts tipped with pale reddish buff. Adult male with a dusky band at the base of the bill, of which color is the throat; a faint white line under the eye; upper part of the neck, sides of the head and the crown chestrut-brown; a broad band of bright green, commencing behind the eye, passing down on the nape, where it is separated by the terminal portion of the crest, which is dark blue; lower part of the lindneck, a small space on the fore-resk, and the siles of the boly undulated with lines of black and white; lower portion of the foreneck and upper part of the breast, reddish-brown, distinctly marked with rounl spots of brownish-black: abdomen yellowish-white, faintly undulated with dusky; a patch of black under the tail: outer

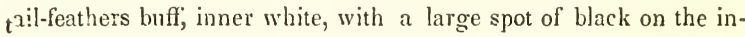
ner webs; tail brown margined with whitish, the cuter feathers greenish-black. Upper parts brown, faintly undulated with black and white, on the fore part of the back; onter scapulars similar, with a portion of their outer wabs black; lesser wing-coverts brown ash. greater coverts tipped with reddish-cream. 'The first five seconda' ries velvety-black; the next five bright green, forming the speculurn, which is bounded above by pale reddish buff, and on each side by deep black; before the wing; a transverse, broad, white band.

Female smaller. Head and neck streaked with brownish-white and dusky, darker on the upper part of the head. Lower parts red. dish-brown, the feathers margined with dusky, upper parts dusky brown, the feathers margined and spotted with pale reddish-white, without the chestnut red, and the green on the head, the black patch 
is wanting as is the white band before the wings, the conspicuous spot on the wings is less extensive. Its short and narrow bill is at all times a strong specific character. Length fifteen inches, wing seven inches and a hall:

'This bird, peculiar to America, was for a long time considered identical with the Greer.Winged Teal of Europe. At the present day, I believe it is very generally understcod, at least on this side of the water, to be a distinct species, as the difference in markings between those procured in Europe and America, fully authoris:.

The Green-Winged T'eal arrives among us, from its brecding. place at the North,; in the latter part of October. Many remain quite late in the Winter. Associated usually in focks, they frequent the streams and ponds, where they feed on insects and tender plants. In the early part of the season, they sometimes visit the ponds on the beach, though generally confined to creelis and mill-ponds. At the South, during Winter they are very abundant, and resort to ricefields in company with the Mallard. Their flcsh is highly esteemed, being tender and juicy, and always commands a high price in our markets. In many parts of South America, it is also said to be rery abundant.

\section{ANAS DISCORS-LINN.}

\section{BLUE-WINGED TE.AL.}

Blue. Wingrd Teal, Auas disecı, Wils. Amer. Orn.

Anas diccors, Bonap. Sin.

Anas discors, Blue-wingéd Teal, Sw. \& Rich.

Jlur. Wingral 'l'ca', Nuit. Min.

Blue- Winged 'Thal, Anas discors, Aud. Orn. Biog.

Specific Character-Bill bluish-black, and long in proportion with the other dimensions of this species, smaller wing corerts, light bluc, speculum purplish-green. Adult male with the upper part of the head black; a broad band of white on the sirles of the head, before the eye, margined with blacli; rest part of the head, and upper part of the neck grayish-brown, with purple reflections on the hind-neck; chin black; lower parts redlish-brown; lower part of the fore-neck and sides of the boly, spottel with blackish-brown; breast and abdomen barred with the same color; lower tail-coverts blaclish-brown 
Tail brown, margined with paler, the feathers pointed, a patch of white on the sides of the rump; back brownish-black, glossed with green; the feathers on the fore part of the back and lower portion of the hind-neck margined with yellowish-white. Primaries brown; inner webs of the secondaries same color; outer vanes dark green, which form the speculum; secondary coverts brown, the outer broadly tipped with white, the inner tipped with blu'; tertials dark green, with central markings of deep buff; feet dull yellow.

Female without the white patch on the sides of the head; throat white; lower parts grayish-brown, the feathers spotted with clarker; upper parts blackish-brown, the feathers margined with bluish white and pale buff; smaller wing-coverts blue; speculum green; secondary coverts the same as those of the male. Length fourteen inchcs, wing seren inches and a half.

T'he Plue-Winged Teal is the first of its tribe that leares the Nortl. Subsisting on tender plants and insects, early in the season, it is compelled to migrate to a milder climate, and arrives among us usu. ally in the month of September. It takes up its atode near the small streams and mill-ponds, where an abundant supply of its farorite food is found. It remains with us but a short time, and then res:umes its journey to the most southern extremity of the Union.

This species breeds on Long Island. At "Fort Pond," Montaul, it is said a few are found brecting every season. 


\section{ANAS CLYPEATA-IINN.}

\section{SHOVELI.ER DUCK.}

Shoveller, Anas clypesta, Wils. Amer. OnI.

Ands c'speara, Bunap. Syu.

Alas clyp cala, Shoveller, Sw. \& Rich.

Shoveller. Null, Man.

Shoviller Duck, Aıas clỵpata, Aud. Orn. Biog.

Specific Character-Bill brownislı-black, about three inches in length, near the end it is more than wice as broad as it is at the base, much rounded and closely pectinated, the sides of the upper mandible at the base having the appearance of a fine toothed comb. Aduit male with the hexd and the neck, (for about half its length,) glossy green with purple reflections; lower part of the neck, and upper part of the breast, white; rest of the lower plumage deep chesnut brown, excepting the lower tail-coverts and a band across the rent, which is black, some of the feathers pattly green; nanks brownish-yellow, pencilled with black and blackish-brown; inner secondaries dark green with a terminal srot cf white; outer secondaries lighter green; primaries dark brown, their shafis white, with dusky tips; lesser wing-coverts light blue; speculum golden green; rump and upper tail coverts greenish-black, a patch of white at the sicles of the rump; tail dark brown, the feathers pointed, broadly edged with white, of which color are the inner webs of the three outer feathers.

Female, with the crown dusky; upper plumage blackish-brown, the feathers edged with reddish-brown; breast yellowish-white, marked with semi-circular spots of white. Young male with similar markings on the breast. Length twenty inches and a half, wing ten.

This species is known to our gunners by the name of "Spoonbill." Occasionally it is met with along the sea coast, but is more generally found in our lakes and fresh water streams. Its Cesh is esteemed, being tender and juicy. In this vicinity it is not abundant. According to Mr. Audubon, it breeds from T'exas westward to the Columbia River and the Fur Countries. 


\section{GENUS FULIGULA.}

\section{SEA DUCKS.}

[In this class, the head is rather larger, neck rather shorter and thicker,

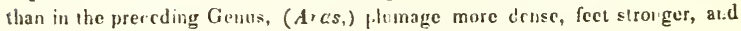
the hind toe with a brosd appendage, which is the priracipal distinctio:t.]

\section{FULIGULA VALISNERIANA-WILSON.}

\section{CANVASS BACK DUCK.}

Canvass backed Duck, Anas valisneris, Wils. Amer. Orn.

Fuliguld valisseria, B najp. Syu.

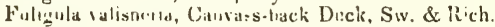

Caluviss-back D.uck, Fuliguld valisueriana, Aud. Oru. Biog.

Canvass backed Duck, Nutt. Mun.

Specific Character-Bitl black, the length abont three inches and very high a: the base; fore part of the head a: d the hiroat dusky; irides deep red; breast brownish-black. Adult male with tho forehcad, loral space, throat and upper part of the head dusky, sides of the head, neek all round for nearly the entire length, reddish chestnut; lower neck, fore part of the breast aud back black, rest of the back white, closely marked w:th undulating lines of black; rump and upper tail-coverts blackish; wing-corerts gray, speckled with blackish; primaries and secondaries light slate color. 'Tail short, the feathers poinled; lower part of the breast and abdomen white; flanks sane color, finely pencilled with dusky; lower tail-coverts blackish-brown, intermixed with white. Length twenty-iwo inches, wing nine and one quarter.

Female, upper parts grayish-brown; neck, sides and abdomen the same; upper part of the breast brown; belly white, pencilled with blackish; rather smaller than the male, with the crown blackisl.brown.

This species is not found in any part of Eurcpe. Its richly fla. vored flesh is admitted by all to be superior to any other of this 
genus. The Canvass-back Duck returns from its breeding place at the Norih, about the first of November, and luring winterex. tends to the southern portion of the sea-coast of the United S:ates. It is not unfrequently shot in the eastern part of the Great South Bay, and I have known it to be captured in Iong Island Sound. The majority, howerer, congregate on the Promac and Delawarc rivers. Those procured in the vicinity of New York are inferior to those obtained on the iributarics of the Chnsapeak, owing to the difference in the quality of its food. The Canvass-back feeds chicfly on the Znstera valisnerici, (commonly tormed "lape or cel grass," and by sume improperly called wild cellery,) which takes its growt: in brackish water. We do nct wish this plant to be confounded with the "lape or ecl grass:" Zostera marina, which furnishes food for the Brent Goose. When its farorite fod cannot be obtained it fecls on various marine plants and small slell-fish that abound on our coast, which furnish an abundant supply of food to many species of inferior note. IVhen lhe valisneria cannot be obrained, its flesh lonies, in a great measurc, that delieacy of flavor for which it is so justly celcbrated. Like most oilıer species, it is in the best condition for the table during lise latter part of Autumn. The Canrass-back is also fond of wheat. Wilson mentions an instance of a ressel loaded with wheat being wrecked at Egg Har. bor, New Jersey. "Large focks were attracted to the spot: two hundred and fifiy were killed in one day, and sold at twelve and a half' cents a pair. 'The gunners called them 'Sea Ducks,' and were ignorant of theil value." The Canrass-back Duclis associate in large flocks-when rising from the water, are heard at a great distance: it is vigilant and difficult to approach, except in scverc weather, when it is readily killed at "air openings" in the ice.It is an cxcellent diver, and when wounded is difficult to secure.

Miller's Island, about fiftecn miles from Baltimore, is a famous place for shooting Canvass-backs, as well as other species of Ducks. "Points" on this Island, and others in the vicinity, are rented for large sums by parties who practise Duck-shooting. In this section "decoys" are not used, and the unsportsmanlike manner of sail. ing after and harrassing them on their feediug grounds, is not re. sorted 10. 


\section{FULIGULA FERINA-LINN.}

\section{RED.HEADED DUCK.}

Ricd-bcaded Duck, Anas ferina, Wilson.

Filegula f́rua, Boaap

Fulıgula ferma, $\rightarrow$ w. \& Rich.

Red- caded Diack or Pochard, Nuttall.

licd-licadcd Duck, Fuligule forind, Audubon.

Specific Character--Bill bluish, toward the cnd black, and atout two inches and a quarter long; irides yellowish-red. Adult male with the head, which is rather large, and the upper part of the neck all round, dark reddish-chestnut, brightes: on the hind neck; lower part of the neck, extending on the back and upper pant of the breast, tlack; abdomen white, darker toward the rent, wherc it is barred with undulating lines of dusky; nanks gray; closely barıed with black, scxpulars the same; primaries brownish-gray, sccondaries lighter; back grayish-trown, barred with fine lincs of white; rump and upfer tail covests blackish-brown; tail feathers grayishbrown, lighter at the base ; lower tail coverts brownish-black, rather lighter than the upper. Length twenty inches, wing nine and a half. Female about two inches smaller, with the head, neck, breast, and general color of the upper patts brown, darker on the upper pait of the head, lighter on the back; bill, legs, and feet, similar to those of the male.

With us the Red-headed Duck is not as common as many other species, and is seldom seen in numbers west of Babylon, being chiefly confined to the eastern part of the South Bay, where it is sometimes seen in company with the Canvass Back, feeding on the stcms of the same plant, the latter preferring the roots, being more tender and juicy, which imparts to its flesh a delicate flavor. 'The Red-headed Duck is also excellent, commands a high pric? in our markets, and is firequently sold to the inexperienced as Canvass Back, which it so closely resembles that the deception is casily practised upon those who have never compared the species. It is readily identified by the difference in the color of its eyes, as well as by the form of its bill. 
At Egg Harbor, the Red-headed Ducks are more common than they are with us, but not so plentiful as on the Chesapeake, where the majority assemble during winter.

Frequent attempts have been made to domesticate these birds, but only in one instance do I know of its having been attended with success. This was with an individual in the possession of Edmund Powell, Esq., of Westbury, L. I., who has induced it to become completely reconciled to its new home, as though it had never known any other course of life. This gentleman seems to hdve a peculiar faculty for subduing the wild propensities of birds, of which he has a greater variety domesticated by him than I have seen in any other part of the country. It is not only a great embellishment to his residence, but at times the means of affording convenient shooting, as they always invite straggling parties when crossing the land to stop and share with them; the invitation, given with'so much earnestness, and being hailed in their own language, they seldom fail to alight on the pond without in the least suspecting the treachery of their kinsmen. The Red-headed Duck arrives with us usually about the first of November-early in March it leaves for the North, where it breeds.

\section{FULIGULA MARILA-LINN.}

\section{SCAUP DUCK.}

Anas marila, Wils. Amer. Orn.

Fuligula marila, Scaup Duck, Sw. \& Rich.

Scaup Duck, Nutt. Man.

Specific Character-The head and the neck all round, with the fore part of the breast and the fore part of back black; the sides of the head and the sides and hind part of the neck dark green, reflecting purple; length of bill when measured along the gap, two inches and five-sixteenths; length of tarsi one inch and threeeighths; length from the point of the bill to the end of the tail nineteen inches, wing eight inches and five-eighths; a broad white 
band crossing the secondaries and continues on the inner primaries. Adult male with the forehead, crown, throat and upper part of the fore-neck brownish-black; sides of the head, neck and hindneck dark green; lower portion of the neck all round, with the upper part of the breast purplish-black, rest of the lower parts white, undulated with black toward the vent; under tail-coverts blackish brown; tail short, dark brown, margined and tipped with lighter brown; upper tail-coverts and rump blackish-brown, middle of the back undulated with black and white, fore part black; wings brown, darker at the base and tips, speculum white, formed by the band crossing the secondaries and inner primaries; scapulars and inner secondaries undulated with black and white; secondary coverts blackish-brown, undulated with white. Female with a broad patch of white on the forehead; head, neck and fore part of the breast, umber brown; upper parts blackish-brown; abdomen and lower portion of breast white; scapulars faintly marked with white.

This common Duck is more generally known to our gunners by the name of "Broad-Bill" or "Blue-bill." According to Willoughby, it takes its name from a certain small kind of shell fish, on which it feeds.-Wilson. It is met with along the whole extent of the Atlantic coast, and is a regular visitor along our western lakes. It arrives among us from the 10 th to the 20 th of October, associates in large flocks, and on its first appearance is easily decoyed, but after having been frequently shot at becomes more shy. In stormy weather it takes shelter in the coves, and is frequently decoyed within gun-shot from the shore by having a dog trained for the purpose of swimming between it and the shore, as also by quickly moving a red handkerchief every few seconds, keeping your person concealed. This manœuvre either charms or irritates it; I am inclined to think the latter, from the impetuous manner in which it approaches. The scene is truly ludicrous. I have tried this method with other species without success. It remains with us in the winter until the severity of the weather compels it to leave for a better supply of food. When passing over frozen bays I have killed it at "air openings." When wounded, it avoids pursuit by diving, and is famous for skulking under the banks. 
It is no particular advantage to have a large flock come up to the decoys, for the instant you rise to fire, they scatter in all directions, so that it is difficult to get over two in range; when a flock swims up to you, as it occasionally happens, of course greater havoc is made. It passes the night on the flats in large flocks, seldom or never roosting on the marshes or meadows, and is very quick in discovering the best feeding grounds. In passing through the nar. row 'leads,' (as the gunners term the narrow creeks and channels that form those beautiful islands in our wide bays, ) to its favorite feeding grounds, it is easily killed without decoys. It returns to us early in the spring, and remains until the mild weather invites its vernal flight. When in good condition, its flesh by many is esteemed. In flying it seldom makes any other noise than that produced by the action of its wings; but in calm weather when swimming leisurly about, it gives utterance to a quick rattling or rolling sound. Its migratory flight is high and rapid. In winter it is common on the Ohio and Mississippi Rivers and their tributaries. In the Chesapeake Bay, where it is abundant, it is called "Black-headed," in Virginia, "Raft Duck."

\section{FULIGULA MINOR.}

\section{LESSER SCAUP DUCK.}

Fuligula marila, And.

Specific Character-Length of bill along the gap two inches; of tarsi one inch and an eighth ; from the point of the bill to the end of the tail feathers seventeen inches; wing eight inches. Adult with the feathers on the head longer, more tufted, than $F$. marila; the head and neck more deeply tinged with purple; the white markings on the wings confined to the secondaries, while in $F$. marila the white band spreads over the primaries.

The female is smaller than the male, and bears the same resemblance in markings to the male as the female of $F$. marila does to the male of that species. The white band on the wings as pointed out is at all times the best specific character. 
This bird is very closely allied to the preceding, so nearly that it has been overlooked and confounded with that species by our most eminent Ornithologists. On a close investigation, we find well defined specific characters in marking, \&c., as well as inferiority in point of size. The Lesser Scaup Duck is well known to the bay gunners by the name of "Creek Broad-Bill," from its habit of frequenting the small streams, while the Scaup Duck ( $F$. marila) is usually observed on the open bays. It is a very abundant species, and during Autumn and the early part of Spring, is quite common along the middle Atlantic districts, as well as on the streams in the interior. Its choice of food, migrations and breeding range, are similar to the former.

\title{
FULIGULA RUFITORQUES-BONAP.
}

\author{
RING-NECKED OR TUFTED DUCK.
}

Tufted Duck, Anas Fuligula, Wils.

Ring-necked Duck, Anas (Fuligula) rufitorques, Sw. \& Rich.

Ring-necked Duck, Fuligula rufitorques, Nutt.

Ring-necked Duck, Fuligula rufitorques, Aud.

Specific Character-Head tufted; bill about two inches long, very high at the base, the ridge at the base unusually broad, at the base margined with a rather broad band of yellowish green, a broader band of the same color between the nostrils and the tip, the remaining part of the bill dark slate color; chin white; spec. ulum or wing spot bluish-gray. Adult male with the plumage of the head and upper part of the neck black, with purple reflections; at the base of the lower mandible a triangular white spot; the middle of the neck encircled with chestnut ; the upper part of the breast black; abdomen white, spotted with brown and tinged with yel. low ; flanks ash-gray, undulated with lines of white and dusky ; vent and lower part of the abdomen dark brown, undulated with faint lines of white; lower tail-coverts blackish-brown, tail brown ; upper tail-coverts darker; back blackish-brown; primaries the same 
color ; scapulars and lesser coverts greenish-black ; outer secondaries, outer webs, light slate color, tipped with white; inner webs brown, inner secondaries dark green; secondary coverts brown. Length eighteen inches, wing seven and three quarters.

Female with a band of white on the forehead, head and neck brown, larger portion of the breast and abdomen white; the sides of the body brown. About two inches shorter than the male.

This bird in general markings is not unlike the Scaup Duck, but it can at all times be readily distinguished by the slate colored markings on the wings. By our gunners generally, it is considered a hybrid, and familiar to them by the name of "Bastard Broadbill." Along the sea-coast it is not very abundant; still a few are observed almost every Spring and Autumn along the south shore of Long Island, and at Egg Harbor. On the streams of the interior it is quite common during winter. I have met with it on various parts of the Onio, and on the Mississippi as far as New Orleans.It associates in small parties, and is usually observed flying but a short distance above the water.

The largest flock I ever met with, was from nine to twelvethose I saw at the mouth of the river Licking; but from my ob. servations, they are not so plentiful in the vicinity of Cincinnati, as farther down the Ohio River. 


\title{
FULIGULA RUBIDA-WILS.
}

\author{
RUDDY DUCK.
}

Ruddy Duck, Anas rubida, Wils. Amer. Orn.

Fuligula rubida, Bonap. Syn.

Fuligula rubida Ruddy Duck, Sw. \& Rich.

Ruddy Duck, Nuu. Man.

Ruddy Duck, Fuligula rubida, Aud. Orn. Biog.

Specific Character-Bill grayish-blue-one inch and seven-eighths long-high at the base-broad and flattened toward the end-eye small-situated high; tail much rounded, the feathers rigid, narrow-the lower plumage stiff and glossy. Adult male with the bill bluish-upper part of the head black, terminating in a point as it extends on the hind neck-sides of the head white-chin white, tinged with yellowish-brown-neck, upper parts, and sides, teddishbrown-lower parts silver-white, barred with dusky-lower tailcoverts white, tinged with yellowish-brown. Tail black, short, and rounded, the feathers very stiff and narrow. Wings blackish-brown. Female, with the crown and upper parts dark reddish-brown, marked with dusky; lower parts duller; throat, and a band from the base of the upper mandible to beneath the eye, brownish-white; bill darker than that of the male. Length fourteen inches, wing six inches.

This species is rare in this vicinity. In Massachusetts Bay it is frequently met with, but in the Chesapeake Bay it is more common, and is known to the gunners by the name of "Salt-water Teal." It frequents the salt ponds along the sea-coast, and, its said, procures its food by diving, subsisting chiefly on marine plants. 


\section{FULIGULA LABRADORA-LATHAM.}

\section{PIED DUCK.}

Pied Duck, Anas labradora, Wils. Amer. Orn.

Fuligula labradora, Bonap. Syn.

Pied Duck, Nutt. Man.

Pied Duck, Fuligula labradora, Aud. Orn. Biog.

Specific Character-Wing coverts and the secondaries white, forming a large conspicuous patch on the wings-the cheeks are furnished with bristly feathers; bill at the base orange, toward the end black; the sides of the upper mandible, very thin, tapering over the under, which is deeply serrated. Adult male with the bill at the base pale orange, anterior to the nostrils blackish; on the top of the head a broad band of black, narrowing as it extends to the occiput; , the feathers on the cheeks are stiff and bristly, of a brownish cast; rest part of the head and upper part of the neck all around white; about the middle of the neck, a broad band of black, forming a complete ring, the same color passing down on the back; lower neck white; upper part of the breast and sides of the body black; the rest of the lower plumage brownish-black, the under tail-coverts lighter; primaries and their coverts brownish-black, secondaries white, a few of their outer webs margined with black ; their coverts the same color; rump and upper tail-coverts dusky, marked with minute spots of grayish-brown. Female, lower plumage ash gray, spotted with brown; upper parts bluish-gray; several of the secondaries and sides of the forehead white. Male, length twenty inches, wing nine inches. Female one inch and a half less.

This species is called by our gunners "Skunk Duck," so named from the similarity of its markings to that animal. With us it is rather rare, "chiefly inhabiting the western side of the continent." In New-Jersey it is called Sand-shoal Duck. It subsists on small shell and other fish, which it procures by diving. Its flesh is not considered a delicacy. A few are seen in our market every season. 


\section{FULIGULA FUSCA-LINN.}

\section{VELVET DUCK.}

Anas fusca, Wilson.

Fuligula fusca, Bonap.

Oidemia fusca, Velvet Duck, Sw. \& Rich.

Velvet Duck, Nuttall.

Velvet Duck, Fuligula fusca, Audubon.

Specific Character-General plumage black; a spot under the eye; a large white patch on the wings, formed by the secondaries. Adult male, the bill with a prominence at the base passing over the nostrils, where it is black-covered at the base with black feathers; anterior to the nostril, orange; reddish at the sides; at the base the sides are black; general plumage brownish-black, with purple and green reflections on the head and hind neck; sides of the body lighter brown; a spot of white under the eye inclining backwards; a large patch of white on the wings, formed by the secondaries; legs reddish-orange. Length twenty-two inches, wing eleven and a quarter. Female sooty brown; bill dusky; the prominence of the base of the bill not as large as in the male; sides of the head marked with two white spots; the prominent white markings on the wings the same as with the male.

This species is better known to our gunners by the name of "White-winged Coot." Large flocks are seen along the entire Atlantic district, keeping outside of the beach, where they subsist by fishing. It seldom visits the small bays, unless driven in by storms, when they are sometimes seen passing over the land.

When migrating, it flies high, performing its long journey from its breeding place at the North in silence. It arrives among us about the middle of October, and remains untik about the middle of April. It is a heavy-bodied bird, and well supplied with down.When in full plumage, a heavily-laden gun is required to stay its onward course. When numerous, on the south shore of Long Island, the gunners watch a favorable opportunity, when the surf is 
down, and with fifteen or twenty boats, form a line about two or three gun-shots apart. In this way it is difficult for a flock to avoid one or the other of the boats. Those used for this purpose are light skiffs, containing generally but one person, as the object is to have the boats light, in order that they may ride the waves with safety.

This manner of shooting should be practised only by experienced baymen, for if the wind comes in suddenly from the south, as sometimes happens, it causes the surf to rise-on such occasions, even the most skilful are occasionally drowned.

In Water Fowl shooting, a very general error is practised in using too heavy lead. I have noticed it particularly with this species, having often seen the bird strike the water, coloring it for a space with blood, yet still dive and swim off vigorously. This may be accounted for by the large shot lacerating the flesh in such a manner, that when it escapes the vitals, the bird is relieved by bleeding. Lighter lead makes a smaller wound, which instantly closes, thus depriving it of such relief. When using smaller shot, you have also a better chance for hitting your mark, as a larger number of pellets is contained in the same weight.

The flesh of the Velvet Duck is not esteemed, being dark colored and fishy, although large numbers are sold in our markets. Common to both continents, and is said to lay from eight to ten white eggs.

\section{FULIGULA PERSPICILLA'TA-LINN.}

\section{SURF DUCK.}

Anas perspicillata, Wilson.

Fuligula perspicillata, Bonap.

Oidema perspicillata, Surf Duck, Sw. \& Rich.

Black or Surf Duck, Nuttall.

Surf Duck, Fuligula perspicillata, Audubon.

Specific Character-Bill reddish-orange, paler at the sides and tip; a patch of black at the sides of the base of the upper mandible, where it is very broad and high; nostrils large, perfectly free, and arched; the upper part of the upper mandible as far as the nostrils, 
covered with black feathers, of which color is the entire plumage, excepting a patch of white on the crown and hind neck; eyes white; legs and feet reddish-orange. Length twenty inches, wing nine and a half. Female smaller, with the bill greenish-black; lower plumage brownish-black; upper parts and the tail feathers darker.

This is another of those hardy sea-birds that by our gunners generally are termed "Coots." The Surf, or "Spectacle Duck," as it is by some called, associates with the former species, and the habits of both are similar.

When at Montauk Point in the autumn of 1834 , on walking out in the morning after a very stormy night, looking up at the Lighthouse, I was surprised to see a bird suspended from the wire frame that protects the glass. On taking it down, I recognised it to be a Surf Duck. The wind had been very high the night before, and doubtless the water became so agitated that it was obliged to take to wing-and being attracted by the light, and flying with great force, it thrust its head through the wires, in which situation it was strangled.

Mr. Audubon says this species breeds on the coast of Labrador ; makes a nest of grass, lines it with down or feathers, and lays from four to six whitish eggs, which are hatched out in the month of July. The flesh of the Surf Duck is dark-colored and fishy.

\section{FULIGULA AMERICANA-SWAINSON.}

\section{AMERICAN SCOTER DUCK.}

Anas nigra, Wilson.

Fuligula nigra, Bonap.

Oidemia Americana, Sw. \& Rich.

American Scoter Duck, Fuligula Americana, Nuttall.

American Scoter Duck, Fuligula Americana, Audubon.

Specific Character-Bill shorter than the two preceding species, with an abrupt prominence at the base, which is deep orange; anterior to the nostril black, margined on the sides with the same color; general plumage black-bluish on the hind neck, the scapulars tinged with green; tail graduated and pointed; tarsi black, feet the 
same color, and very broad. Length nineteen inches, wing nine. Female smaller, and with the protruberance at the base much less; upper parts brownish-black; lower parts lighter.

This also is one of the "Coots." It passes its time at sea, and subsists by fishing, frequently associating with the Velvet and Surf Ducks. Like all other divers, it is often caught by becoming entangled in the fishermen's nets. In the Eastern States, it is known by the name of "Butter Bill."

\section{FULIGULA MOLLISSIMA-LINN.}

EIDER DUCK. •

Anas mollissima, Wilson.

Fuligula mollissima, Bonap.

Somateria mollissima, Eider, Sw. \& Rich.

Eider Duck, Nuttall.

Eider Duck, Fuligula mollissima, Audubon.

Specific Character-Bill from the corner of the mouth to the end, two inches and three quarters, extending high upon the foreheadthe frontal feathers advance on the ridge, giving it a forked appearance; bill strong at base, gradually tapering to the end; the feathers at the base of the bill extend on the sides of it to the nostrils ; secondaries long, curving over the primaries. Adult male with the sides of the head and crown white; a broad band of bluish-black over the eye; occiput, upper portion of the hind neck, and sides of the neck, pale green; upper part of the fore neck white, lower neck and upper part of the breast buff or cream color, lower parts black; tail blackish-brown; upper tail coverts and central part of the rump black, sides of the latter white, the feathers long, extending nearly to the lower tail coverts, forming a large patch at the base of the tail ; back, scapulars, and small wing coverts, white ; primaries brown-outer secondaries dark brown glossed with blue; large portion of the inner vanes white; inner secondaries white, curving over the primaries. Length twenty-five inches, wing eleven and a half. 
Female with the general plumage brown, barred with blacklighter on the head and neck; secondaries and their coverts tipped with white; head smaller than the male. Length two feet, wing eleven inches. Young male, summer plumage, head and upper part of the hind neck reddish brown, spotted with dusky; entire fore neck, with the lower part all round, yellowish-white, mottled with dusky; lower parts brown, the feathers margined with yellowish-white; sides blackish-brown; tail coverts black; tail brown, broadly tipped with white; back and rump dark brown, a patch of white on the sides of the latter; scapulars white, spotted with brown. Young of the year in winter similar to the female.

This species, so celebrated for the superior quality of its down, is common to both continents. With us, its breeding range extends from Maine, where it is called 'Squam Duck,' to the higher northern latitudes. It makes its nest of grass and sea-weed, lining it with down from the breast of the female; in it she deposits five eggs. After the full number has been laid, the natives rob the nest of both down and eggs. The female again strips her breast and lays a second time. On being again defeated in her purpose, and persisting in raising a brood, the nest is then supplied with down from the breast of the male. In this manner, half a pound of down is collected in a season from one nest. Occasionally it is seen at Egg Harbor and in this vicinity.

"In Greenland, Iceland, Spitzbergen, Lapland, and some parts of the coast of Norway, the Eiders flock together, in particular breeding places, in such numbers, and their nests are so close together, that a person in walking along, can hardly avoid treading upon them. The natives of these cold climates eagerly watch the time when the first hatchings of the eggs are laid; of these they rob the nest, and also of the more important article, the down. The quantity of this valuable commodity, which is thus annually collected in various parts, is uncertain. Buffon mentions one particular year, in which the Icelandic Company sold as much as amounted to upwards of $£ 850$ sterling."-Bewick's British Birds. 


\section{FULIGULA SPECTABLIS-LINN.}

\section{KING DUCK.}

Fuligula spectablis, Bonap. Syn.

Somateria spectablis, Kirig Dnck. Sw. \& Rich.

King Duck, Fuligula spectablis, Nutt. Man.

King Duck, Ful gula spectablis, Aud. Orn. Biog.

Specific Chaarcter-Length of bill from the termination of the frontlet feathers, which extend over the gibbous substance at the base of the upper mandible one inch and a quarter-tarsi one inch and a half, tail long, rounded, the feathers pointed. Adult male with the bill pale yellow; at the base of upper mandible a compressed gibbous substance, the color bright orange, the front covered with short black feathers, the sides margined with the same color, the feathers extending back in a point nearly to the eye. Head bluish-gray, darkest on the hind head; cheeks shaded with sea-green, a spot of black below the eye inclining posteriorly; on the throat two lines of black forming an inverted $\mathrm{V}$; middle of the neck white; lower neck and fore part of the breast buff; lower plumage blackish-brown; a large spot of white on either side of the rump, fore part of the back same color, posteriorly black. Wings and tail brown, the former broadly marked with white; in the adult the secondaries curve over the primaries, but this character I have never observed in the young.Length twenty-five inches, wing ten inches and three-fourths.Young, dark brown, margined with whitish, lighter on the neck; the gibbous substance on the upper mandible scarcely perceptible.

This remarkable Duck is seldom seen within the limits of the $U$. States, although I had the good fortune to add to my collection an adult male in perfect plumage, that was shot on Long Island Sound. in the winter of 1839 .

The King Duck is an inhabitant of the higher latitudes of both con tinents; feeds at sea, and only resorts to land for the purpose of reproduction. It is nearly allied to the Eider Duck, and equally valuable for the superior quality of its down.

During winter-at Egg Harbor as well as on the shores of Long Island-the young are occasionally observed. But the adult specimen now in my possession, and one other, are the only individuals in full and mature plumage, that I have ever known to be procured in the vicinity of New-York. 


\section{FULIGULA CLANGULA-LINN.}

\section{GOLDEN-EYE.}

Golden-eye, Anas Clangula, Wils. Amer. Orn.
Fuligula Clangula, Bonap Syn
Clangula vulgaris, Common Golden-eye, Sw. \& Rich.
Common Gulden eye, Nutt. Man.
Gulden-eye Duck, Fuligula Clangula, Aud. Orn. Biog.

Specific Character-Bill black, high at the base, where there is quite a large spot of white; head ornamented with a beautiful crest, the feathers more than an inch long and loose, insides yellow; the entire head and upper part of the neck rich glossy green with purple reflections, more particularly so on the throat and forehead; rest of the neck. with the entire plumage, white; sides of the rump and vent dusky gray; tail grayish-brown; back and wings brownish. black, a large patch of white on the latter, formed by the larger jortion of the secondaries and the tips of its coverts; legs reddishorange. Length twenty inches, wing nine inches. Female, head and upper part of the neck dull brown; wings dusky; lower parts white, as are six of the secondaries and their coverts; the tips of the latter dusky. About three inches smaller than the male.

This species is better known to our gunners by the name of "Whistler," from the peculiar whistling noise produced by its wings when flying. By some it is called "Crreat Head," from its beautiful, rich, and thickly-crested head.

With us, the Golden-eye is not a very numerous species, arriving about the same time that a majority of its tribe are compelled to quit the "great nursery" at the North for our more temperate climate. I have met with it in the Fall and Spring at Egg Harbor, Delaware and Chesapeake Bay, as also on Long Island. On the interior streams it is more common. Its food consists of small shell and other fish, which it procures by diving. In the Fall, its flesh is equal to the Scaup Dack, and by many considered superior. Its uncommon shyness makes it difficult to be decoyed; I have often had it pass my decoys when well concealed without offering to approach. In stormy weather it takes shelter in the coves with the Scaup Duck, where it is more readily lilled; it usually flies rather high, making no other sound than that produced by the action of its wings. 


\section{FULIGULA ALBEOLA-LINN.}

\section{BUFFEL HEADED DUCK.}

Buffel-headed Duck, Anas albeola, Wils. Amer. Orn. Fuligula albeola, Bonap. Syn.

Clangula albeola, Spirit Duck, Sw. \& Ricl.

Spirit Duck, Nutt. Man.

Buffel-keaded Duck, Fuligula albeola, And. Orn. Biog.

Specific Character-Bill blue, from the corner of the mouth to the end about one inch and a haif, the sides rounded, narrowed toward the point-head thickly crested, a patch behind the eye and a band on the wings white. Adult male with the plumage of the head and neck thick and long; forehead, loral space and hind neck rich glossy green, changing into purple on the crown and sides of the head; from the eye backwards over the head a triangular patch of white; the entire breast and sides of the body pure white; abdomen dusky white; tail rounded, grayish-brown; upper tail-coverts lighter; under tail-coverts soiled white; back and wings black, with a patch of white on the latter. Fernale, upper plumage sooty-brown, with a band of white on the sides of the head; otiter webs of a few of the secondaries same color; lower part of the fore-neck ash color; breast and abdomen soiled white; tail-feathers rather darker than those of the male. Male fourteen and a half inches long, wing six inches and three-fourths. Female rather smaller.

This beautifully variegated little Duck receives its name from the disproportionate size of its head to the body. From its constant diving, it is called by our gunners "Dipper." I will here remark, that the true American Dipper, (Cinclus Americanus,) has only been found at the Columbia River. The marked difierence in the plumage of the male and female Buffel-headed or "Spirit Duck," as it is sometimes called, induces many to suppose that they are distinct species. I have met with it in various parts of the United States; and indeed, during the Spring and Autumn, it is dispersed throughout the Union, visiting the interior as well as the sea coast; it dives so dexterously, that when sitting on the water it is very difficult to kill it, even with percussion caps. It is an excellent swimmer, and flies swiftly; its food consists of small fish; it 
is generally in fine condition, but not considered a superior bird for the table. In New-Jersey, it is called "Butter Box," or "Butter Ball." Its note is a single quack. It is generally met with in pairs until the appearance of Spring, when it is seen in small flocks; it arrives with us in October, remaining until the latter part of April, when it leaves for its summer residence at the North, where it breeds.

\section{FULIGULA HISTRIONICA-LINN.}

\section{HARLEQUIN DUCK.}

Anas histrionica, Wils. Amer. Orn.

Fuligula histrionica, Bonap. Syn.

Clangula histrionica, Harlequin Duck, Sw. \& Rich.

Harlequin Duck, Fuligula histrionica, Aud. Orn. Biog.

Specific Character-Bill yellowish-olive, from the frontlet feathers to the point one inch, much narrowed toward the end; neck short, body full, rounded, tail rather long, pointed. Adult male with a broad streak of black commencing at the base of the upper mandible, passing over the top of the head, margined behind with reddishbrown; cheeks anterior to the eye, white-a spot behind the eye of the same color; a longitudinal or slightly curved line of white on the neck; sides of the head and neck purplish-blue, lighter on the hind neck and above the eye; a broad band of white below the middle of the neck, forming a complete ring; a broad band of white before the wing, passing around on the breast, both edged with black ; fore part of the back light blue, changing to black on the hind part; quills dark brown; scapulars white, secondaries tipped with white, forming a band across the wings; fore part of the breast light blue; abdomen brownish; tail grayish-black, the feathers pointed; sides reddish-brown; under the tail at the base, counter spots of white.Female, grayish-brown, intermixed with grayish-white on the breast -deeper on the head and rump; a spot of white intermixed with gray anterior to the eye; behind the ear a spot of white. Length seventeen inches, wing seven inches and three-fourths.

On the sea-coast of the United States, this singularly marked bird is rarely met with. It is said that it breeds at Labrador, and is oc- 
casionally observed in Massachusetts Bay. I have seen several handsome specimens that were procured at Halifax, at which local. ity I am informed it is rot uncommon. On the shores of Long Island I have known the young only to occur, although some of our most experiencell bay-men say that a number of years since, the occurrence of the adult was not unusual.

"The Harlequin Duck is an inhabitant of both continents. It is an excellent diver-has a whistling note-flies swiftly, and to a great elevation." Its singular and handsome markings render it very conspicuous, and it is known to the gunners by the high-soun. ding appellation of the "lord." It is much admired in cabinet, and its flesh is said to be superior for the table.

\section{FULIGULA GLACIALIS-LINN.}

\section{LONG-TAILED DUCK.}

Long-tailed Duck, Anas glacialis, Wils. Amer. Orn.

Fuligula glacialis, Bonap. Syn.

Long-tailed Duck, Harelda glacialis, Sw. \& Rich.

Long-tailed Duck, Nutt. Man.

Long-tailed Duck, Fuligula glacialis, Aud. Orn. Biog.

Specific Character-Length of bill, from the termination of the frontlet feathers to the point, one inch and one sixteenth-the upper mandible rounded; the sides very thin; the bill rather deeply serrated, and furnished with a long nail ; tail-feathers acute. In the male the middle pair of tail-feathers are extended about four inches beyond the next longest, which character is wanting with the female. Adult male with the bill black at the base; anterior to the nostril reddishorange, with a dusky line margining the nail; fore part of the head white, the same color passing over the head down the hind-seck on the back; eyes dark red; cheeks and loral space dusky white, with a few touches of yellowish-brown; a black patch on the sides of the neck terminating in reddish-brown; fore-neck white; breast brownish-black, terminating in an oval form on the abdomen-the latter white; flanks bluish-white; primaries dark brown; secondaries lighter brown, their coverts black; a semicircular band of black 
on the fore part of the back; the outer two tail feathers white-the rest marked with brown, excepting the four acuminated feathers, which are blackish-brown, the middle pair extending several inches beyond the others. Female vithout the long scapulars, or elongated tail feathers; bill dusky-green; head, dark, grayish-brown; a patch of grayish-white on the sides of the neck; crown blackish; upper parts dark grayiṣh-brown; lower parts white. Length of male from the point of the bill to the end of the elongated tail feathers, twenty-three inches, wing eight inches and five eighths. Female about six inches less in length.

This hardy bird at the South is known by the name of "South Southerly ;" in this vicinity it is called by our gunners "Old Wife," or "Old Squaw." The Long-tailed Duck is about the last that leaves its natal regions. Provided with a covering sufficient to protect it from the most piercing blast of Winter, it struggles amid the icy barriers until compelled to seek a better supply of food. When in large flocks, they leave the inhospitable regions of the North for a milder climate; they soon separate in small parties, and in the course of the Winter are to be met with throughout the Atlantic dis. tricts. It is very tircid, and lieeps such rigilant watch, that it is difficult to approach; it is very expert in diving, passing so rapidly under water that when sitting it is almost impossible to shoot it. The most successful maner is by sailing after it. On the wing, it is the swiftest of its tribe, and the most difficult to shoot. Its body is thickly coated with down-its flesh is tough and fishy; and is occasion. ally seen on the small streams in the interior. Common along the Atlantie districts. 


\title{
F A M I L Y M R G I N E.
}

\author{
MERGANSERS. \\ GENUS MERGUS-LINN.
}

\section{MERGANSERS.}

[Bill straight, higher than broat at base; much smaller toward the end; upper mandible hookel; teeth sharp; liead rather large, eompressed; body rather long depressed; plimage very thick; feet placed far behind; wings moderate, acute; tail short, rounded.

\section{MERGUS MERGANSER-LINN.}

BUFF-BREASTED MERGANSER, OR GOOSANDER.

\author{
Mergus Merganser, Wilson. \\ Mergus Merganser, Bonap. \\ Merisus Merganser, Goosander, Sw. \& Rieh. \\ Goosander, Mergus Mergauser, Nutiall. \\ Goosander, Mergus Merganser, Audubon.
}

Specific Character-Forehead low; head rounded, crested; bill bright red, the ridge black, high at base; upper mandible much hooked. Adult male with the head and upper part of the neck greenish-black; lower portion of the neck white; under plumage light buff; delicately tinged with rose color, which fades after death; sides of the rump crrayish-white, marked with undulating lines of dusky; fore part of the back and inner scapulars glossy black; hind part of the back asli-gray; the feathers margined and tipped with grayish-whitc, lighter on the rump; upper tail-coverts gray, the feathe:s marked with central streaks of dusky; tail-feathers darker; primarics dark brown; wing coverts and secondaries white, the outer webs of the latter edged with black; the basal part of the greater coverts black, forming a conspicuous band on the wings; under tail-coverts white; outer webs marked with dusky-gray, which is the color of the greater part of the web; bill and feet bright red. Female, with the head and upper part of the neck reddislu-brown; throat and lower neck in front white; breast and abdomen deeply tinged with buff; upper parts and sides of the 
body ash-gray; speculum white. Length of male twenty-seven inches, wing ten and a half. Female about three inches smaller. Young like the fernale.

This species is better known to our gunners by the name of "Shell-Drake." In its migratory course it visits the whole extent of the Atlantic coast, and is met with in the neighborhood of the interior lakes. With us, it arrives late in the fall, and continues its vocation of fishing, until compelled to leave with others of its tribe, for a milder climate, in search of food. On its first appearance, it is seen in large flocks, but soon disperse in small parties of from five to twelve, frequently associating with the Scaup Duck.

It is easily decoyed, and when wounded, dives so dexterously that it is next to impossible to secure it. When badly wounded, it dives to the bottom and clings to the grass-in this situation I have often found it in the shallow bays. The male does not appear in perfect plumage until the third year. The difference in plumage of the adult male, from the young male and female, is so strongly marked, that our gunners consider it a distinct species, calling the former "Weaser," or large "Swamp-Shell-Drake. The young male can always be distinguished from the female, which it resembles in plumage, by a bony enlargement in the throat. The crest of the young is much greater than that of the adult-that of the male when in full plumage almost entirely disappears.

In the Spring, it again assembles in large flocks, preparatory to Ieaving for its summer residence. At this season it generally flies along the "bottom-lands" at a short distance from the shore. It is readily killed from a "gunning-hole" cut in the bank for that purpose.

The Goosander is very tenacious of life. When fairly shot down, if the lead has missed the vitals, the next moment it is off. In the Spring of 1840 , at the close of a day's fine sport, when preparing to collect my decoys, a single young male Gonsander ap. peared in the midst of them, presenting a fine mark. I brought him down, and suffered him to drift about until I had collected my decoys. I then took him up about a hundred yards from where he fell, supposing him to be dead. I threw him into my boat, and made sail for the shore. After having performed about half of my passage, (two miles, to my surprise he left the boat, flying off as 
if nothing had happened. Forgetting my gun, I looked on with astonishment, keeping my eye on him until he was lost to view ; glancing at the place which he had left, I saw a collection of blood, and came to the conclusion that the lead which brought him down, had also performed the office of surgeon, and by bleeding he was resuscitated. Although feeding upon fish, in the fall its flesh is tolerable. In the Spring, an oily substance diffuses itself through the body, and the flesh is rancid. In calm weather they collect in parties and amuse themselves by diving; at a given signal they pass under the water, some minutes elapsing before they rise. In this way they pass hours, seeming highly delighted with their frolic. In overcast and blustering weather, they keep moving about all day; in heavy storms, they take shelter in coves, and are occasion. ally seen steering up the small creeks to roost in swamps.

\section{MERGUS CUCULLATUS-LINN.}

\section{HOODED MERGANSERS.}

Hooded Merganser, Mergus cucullatus, Wilson.

Mergus cucullatus, Bonap.

Mergus cucullatus, Hooded Merganser, Sw. \& Rich.

Hooded Merganser, Nuttall.

Hooded Meryanser, Mergus cucullatus, Audubon.

Specific Character-Bill black, rather short and narrow; head furnished with a rounded crest, which is erect, rather high, and double; irides yellow. Adult male with the head ornamented with a double erect and high crest, the fore part of which is black, the hind part white, bordered with black; sides of the head and the upper part of the neck greenish-black; lower neck, breast, and abdomen white; sides of the body brown, barred with dusky; lower tail coverts brown, spotted with lighter brown; tail dark brown, much rounded; back brownish-black, which color passes round on the breast; primaries brownish-black; inner secondaries greenish-black, with a central line of white; upper tail coverts blackishbrown, margined with lighter brown. Length nineteen inches, wing seven and three quarters. Female smaller-the crest brown, neck and upper parts lighter. 
This beautful species is again improperly termed "Shell Drake." I will here remark that the Shell or "Shield-rake" does not inhabit this continent. The Hooded Merganser, "Water Pheasant," or "Hairy-head," as it is sometimes called, is rather rare in this vicinity. In South Carolina it is more abundant, and is frequently seen on the Ohio and Mississippi rivers. It breeds at the North, and is said to lay four white eggs. It may be readily distinguished by its beautiful black and white crest, which gives a proud appearance to this prettily marked lird. It is an active diver, and subsists by fishing.

\section{MERGUS SERRATOR-LINN.}

\section{RED-BREASTED MERGANSER.}

Red-breasted Merganser, Mergus Serrator, Wilson.

Mergus Serrator, Bonap.

Mergus Serrator, Red-breasted Mergainser, Sw. \& Rich.

Red-breasted Merganser, Mergus Serrator, Aud.

Specific Character-Forehead high, the upper and hind part of the head furnished with rather long, loose, hairy feathers; bill bright red, the ridge dusky; the lower mandible rounderl. The bill is shorter and narrower than that of the preceding species-it is also lower at the base, and the naked space between the nostrils and the frontlet feathers is less extensive. Adult male with the sides of the head and the upper part of the neck greenish-black; head crested; on the middle of the neck a broad band of white; lower nock reddish brown, the feathers margined with darker brown, which gives it a mottled appearance; breast and abdomen white; flanks and sides of the rump marked with undulating lines of dusky; fore part of the back and the inner scapulars black; rest of the back ash gray, marked with white and dusliy; tail grayish brown, margined and tipped with paler brown; outer scapulars white; secondaries black at the base, white toward the tijs; their coverts the same; a few white feathers margined and tipped with black before the wings; feet light red; primaries brownish-black; inner secondaries margined on the outer wets with black. Length twenty-four inches, wing nine and a half. Female smaller; crest 
shorter; head and fore part of the neck light reddish-brown; upper parts brownish-gray; a band of white on the wings, formed by the terminal portion of the secondary coverts; lower parts white.

This species is called by our gunners "Pied Shell Drake." Although not so numerous as the former, during the year it is met with in most parts of the Union. It is said to breed in the neighborhood of the western lakes, and various parts of the United States, laying eight to twelve bluish-white eggs. Like the former, it feeds on. fish, and its flesh is not considered a delicacy.

\section{F A M I L Y P E L I C A N I N E. \\ PELICANS. \\ GENUS PHALACROCORAX-BRISS.}

CORMORANTS.

[Bill nearly straight, and about the length of the head-strong, the upper mandible hooked, lower shorter; at the base, a small naked membrane produced on the throat; neck rather short; body compressed; face and small pouch naked ; feet short, stout ; wings slender; quills stiff; tail rounded, of twelve or more rigid feathers.]

\section{PHALACROCORAX CARBO-LINN. \\ COMMON CORMORANT. \\ Phalacrocorax Carbo, Bonap. \\ Common Cormoraut, Nuttall. \\ Common Cormorant, Phalacrocorax Carbo, Aud.}

Specific Character-Bill dusky, lighter at the base of the lower mandible; general plumage black, glossed with blue; a white patch on the throat; a similar marking on the sides of the body. In summer the head is furnished with long; narrow feathers. Length 37 inches, from tip to tip of expanded wings, 62, tail of 11 feathers.

During autumn this much-despised bird is common in the middle districts. In winter it is common in the Southern States. In spring it passes on to the rocky shores of Newfoundland and Labrador, where, according to Mr. Audubon, it breeds. It inhabits the sea shore, and subsists by fishing. After having satisfied its gluttonous 
appetite it retires to the shore, where it remains in stupid indolence until compelled by hunger to display its great skill at diving, which Mr. Nuttall informs us, is in China turned to profitable account by having birds trained for this purpose. "At a given signal it plunges into the water and quickly rises with a fish, which it is prevented from swallowing by having a ring placed around the lower part of the neck. $\Lambda$ fter the master is satisfied, the ring is taken off, and the bird allowed to fish for itself." "The flesh of the Cormorant is dark colored and rank, and used only as an article of diet among the Greenlanders.

\section{PHALACROCORAX DILOPHUS-SWAINSON.}

\section{DOUBLE-CRESTED CORMORANT.}

Double-crested Cormorant, Sw. \& Rich.

Double-crested Cormorant, Nuttall.

Double-crested Cormorant, Phalacrocorax dilophus, Aud.

Specific Character.-Bill blackish-brown; orbits and naked skin round the chin yellow; behind the eye, a tuft of slender feathers; general color of plumage deep bluish-black, glossed with green; fore part of the back and wings greyish-brown. Tail graduated, of twelve black feathers, the middle feather exceeding the outer ones about two inches. "After the breeding season the tufts disappear. Length thirty-three inches, from tip to tip of expanded wings, fiftyone inches." Tail of twelve feathers.

Five species of this genus have been found in North America. Townsend's Cormorant [P. Townsendii] violet green [P. resplendens] inhabitants of the western side of the continent. The Florida Cormorant [P. Floridanus] is a constant resident in the Floridas.The present and P. carbo are the only species that have been observed in this vicinity. Like the former, the Double-crested Cormorant breeds at the extreme North, and visits the United States during Winter, and at that season extends its migrations as far south as the coast of Maryland."

Its habits are similar to the preceding. 


\section{GENUS SULA-BRISS.}

\section{GANNET.}

[Bill robust, very stont at the base, conical; longer than the head-com. pressed, and oponing beyond the ejes; neek rather short and full; body rather long; face and throat naked; pouch small; wings long, acute; tail wedge shape; feet short, robust ; tarsi very short; toes four, webs broad.]

\section{SULA BASSANA-LINN. \\ COMMON GANNET. \\ Sula bassana, Bonaparte. \\ Gisnet, Sula bassana, Nuttall. \\ Common Gamnet, Sula bassana, Audubon.}

Specific Character-Bill with a greenish tinge toward the base; general color of plumage white; upper part of head and the hind neck yellowish-brown; primaries brownish-black; their shafts white toward their bases; tail long, the feathers white, middle pair long. est; tarsi short. Young, in summer, with the head, neck, and lowcr parts mottled with grayish-brown; upper parts brown, the feathors marked with white. Length about forty inches, wing nineteen inches and a half.

Or this bird I received a fine specimen that was shot on the South Bay, Loag Island, opposite Bellport, and have seen a few others that were procured in the vicinity of New-York. Its occurrence in the bays and inlets is so rare, that it is not generally known to the gunners, although "it ranges southward of the coast at all seasons, as far as the Gulf of Mexico, and is said to breed on the rocks in the Gulf of St. Lawrence, and off the coast of Labrador."-Aud. Synn.

'The Gannets associate in large flocks, and take possession of the rocks near the sea, sometimes collecting in such great numbers that the whiteness of their plumage appears to a distant observer like a bank of snow. It feeds chiefly on fish, which it procures by hc= vering with still, expanded wings-falling on its prey while at the surface of the water. It is common to both continents-and in. England, I am informed, the young are esteemed as food, usually eaten before dinner to invite the appetite. 
Its habits are rather indolent, seeming unwilling to leave its favorite rock except when forced by hunger. Differing from most marine birds, it is incapable of diving, and can only procure its favorite fare when near the surface. During the season of incubation, it is so intent in obeying the great law of Nature, that it suffers itself to be approached and killed on the spot, rather than forsake its nest. Two species are found in the United States-the present and the Booby Gannet [S. fusca, ] the latter rarely seen east of the coast of Georgia.

\section{F A M I L Y L A R I N E . \\ GULLS. \\ GENUS RHYNCHOPS-LINN.}

\section{SKIMMER.}

[Bill longer than the head-straight, exceedingly compressed toward the end; lower mandible much longer than the upper-narrower, truncated or square at the end, fitting into the channel of the upper; body rather short; wings very long; tail forked, of twelve feathers; feet short, not very stout, webs emarginate.]

\section{RHYNCHOPS NIGRA-LINN.}

\section{BLACK SKIMMER.}

Black Skimmer, or Shearwater Rhynchops, Nigra, Wilson.

Rhynchops Nigra, Bonap.

Black Skimmer, Nuttall.

Black Skimmer, or Razor-billed Shearwater, Rhynchops, Nigra, Aud.

Specific Character-Length of the upper mandible along the gap three inches and a half, lower mandible four inches and a quarter, wing fourteen and a quarter, extending three inches and a half beyond the tail. Adult male with the base of both mandibles carmine, ending with black; upper mandible three inches and a half long; lower mandible about one inch longer and very thin; upper mandible grooved, so as to receive the edge of the lower; a band on the forehead; cheeks, throat, and the whole lower parts white; upper plumage black; inner webs and tips of secondaries white; feet bright scarlet. Length nineteen inches. Female about three inches less; the tail feathers white, with a central black band; in other respects similar to the male. 
During winter, according to Audubon, this singular bird congregates in vast multitudes on the coast of Florida. In summer, it is distributed along the Atlantic districts, though not very common with us. At Egg Harbor, it is more common, where it has been found breeding. It associates in small parties, and passes most of its time on the wing-usually observed flying very low, at a short distance from the shore. I have never seen it alight on the water, and do not think it is its custom. Those that I have met with have always been skimming over the surface of the water, ploughing it with their long bills, seemingly in pursuit of small fish, which constitute its chief support. I have never seen it dive, and from the peculiar formation of its bill, we may assert that it only takes its prey when near the surface.

The voice of the Shearwater is harsh and screaming, somewhat resembling that of the Commnn Tern, though stronger. When fishing, it flies steadily, slowly flapping its long wings. At other times its flight is exceedingly swift-equal to, if not surpassing that of the Long-tailed Duck, ( $F$. glacialis.) I am not aware that it has ever been found breeding on Long Island, and it is rarely seen with us except at Midsummer.

\section{GENUS STERNA-LINN.}

TERN.

[Bill longer and more slender than that of Larus, the point very acute; head rather large, oblong; neck thick, rather short; body ovate; wings very long, narrow, and pointed ; the primaries exceedingly long ; tail of modexate length, deeply forked; feet small ; tarsi shorter than the middle toes ; lower portion of tibia naked ; fore toes connected by deeply emarginate webs.]

\section{STERNA HIRUNDO-LINN. \\ COMMON TERN. \\ Sterna hirundo, Wilson. \\ Sterna lirundo, Bonap. \\ Sterna hirundo, Great Tern, Sw. \& Rich. \\ Great or Common Tern, Nuttall. \\ Common Tern, Sterna hirundo, Aud.}

Specific Character-Bill bright coral red, toward the end black; from the corner of the mouth to the point two inches and an eighth 
-from the tip to the ncstril one inch and an eighth; lower mandi. ble one-cighth of an inch shorter than the upper; tarsi clev. en sixtcenths; wings about the same length as the tail; lateral tail feathers about one inch and a quarter longer than the ncxt longest, its outer web dusky. Adult with the upper part of the liead and hind neck black; sides of the lead, fore necti, and the lower parts white; the breast slightly tinged ivith grayish-blue; rump and upper tail coserts white; tail feathers with the inner webs white, the outer webs pale bluish-gray; the onter webs of the lateral tail feathers dusky gray; on the inner webs of the primaries, along the shafts, a grayish-black band, which color widens toward the end, where they are hoary, and shaded with dusky ; outer web of the first primary black; feet bright red. Length sixteen inches, wing ten and a half. In winter, the upper part of the licad is dark brown; the bill at the basc palc orange-toward the and black, the tips yellow; feet ycllowish. Young, in summer, with the bill greenish-ycllow; fore part of the licad light brown; hind head, and a spot before the cye, blackish-brown; upper parts grayish-blue, mottled wisl brown and dusky.

This abundant species arrives among us in the latter part of April ; conmences laying in the month of May, and deposites threc eggs. It is occasionally seen on the interior streams and lakes. In its migratory course, visits the higher latitudes, and returns south in autumn.

The specific characters of no department of our Ornithology are more difficult to determine, with specimens not in full and malure plumage, than are the species comprised in the present and succeccing Genus. The marked difference in plumage, and cther characters which individuals of the same species present furing the various changes occurring from the period at which they are first fledged until arriving at maturity, as wcll as the winter dress of the adult being so very different from that of the spring, a carcful cxamination of cach species in all its varietics of plumage, and fiequent comparisons, are requisite in order to identify them. 'Twelve species of the Genus Sterna inhabit North Ameriea, all of which, it is said, have been found within the limits of the 
United States. S. cantiaca, fuliginosa, stolida, and Havillii, aro confined to the southern portion of the Union. Eight species we have observed within the geographical range of which we are trea.ing, and it is said that the Arctic 'Tern, S. arctica, has becn procured in the same locality-a species I have never met with, either in cabinet or when collecting.

'The present species is common to both continents. It is found in most of the northern parts of Europe during the breeding seasonand according to Montagu, even as far as Greenland and Spilzenbergen; and in America, according to Mr. Auduhon, its breeding range extends as far north as the 57ih parallel of latitude.

The Common Tern arrives on the shores of Long Island about the middle af April, and continues in great numbers until the ap. proach of winter, when they all retire beyond the soulliern limits of the Union. It is a noisy, restless bird; passes rnost of its time in the air, coursing over the beach and meadows in search of in. sects, or skimming swiftly over the surface of the water in pursuit of small fishes, which it sometimes seizes without apparently checking its flight. $\Lambda$ t other times it is observed hovering over a shoal of fry-the instant thcy appear at the surface, it dashes headlong, falling like a weight upon its prey, submerging the head in the offort. It never dives, and allhough web.footed, is seldom seen swimming, and seems to have an aversion to alight on the water. At the reflux of the tide, it resorts to the bars and shoals, mingling with the Gulls, glcaning minute shell-fisls and marine insects which abound in such places. It is of a lively, sociable disposition, moring about in parties, and kecping up a continual chalicring. It also appears to have a fondness for the society of the Black-headed Gull -with which it is often seen associated, and, like its companion, though not pursued by the gunncr, is extremely tirnid and watchful; but when any of their number meet with accident, those within hearing of its shrill cry lock to the spot, and hover round their wounded companion until driven off by the repeated discharge of the sportsman's gun. The eggs arc usually found on the beach, along the south side of the sand hills. They are laid on the naked sand, without any preparation of a nest, other than a slight exca. 
vation made loosely in it, and they are hatched chiefly by the warmth of the sun, the female seldom sitting on them except during the night, or in stormy weather. Here we again meet with a very striking provision in the economy of Nature, [which I shall not at. tempt to define,] as it is certain that this apparent neglect does not arise from a wanton recklessness in regard to perpetuating their kind; for at such times their excursions are confined to the neighborhood of their nests, which, though seemingly abandoned, are watched with all the parental solicitude for which the feathered race are so proverbial. The eggs are usually three. I have frequently found two-sometimes one-and have sometimes found as many as five in one nest. From these very unequal numbers, it appears as if they dropped their eggs indiscriminately about upon the sand; but of this unusual procedure I have no farther proof.

The eggs of the Common Tern are about one inch and three quarters long, and about one and a half wide, of a pale dull brown, tinged with green, and blotched with blackish-brown.

The Common Tern is familiar to our bay-gunners, as well as to many sportsmen, (who never look for generic distinctions,) by the name of "Summer Gull." On the coast of Massachusetts, it is termed "Mackerel Gull."

\section{STERNA MINUTA-LINN.}

\section{LEAST TERN.}

Sterna minuta, Wils. Amer. Orn.

Sterna minuta, Bonap. Syn.

Silvery Tern, Sterna argentea, Nutt. Man.

Least Tern, Sterna minuta, Wils. Amer. Om.

Specific Character-Bill yellowish-red, toward the point black, in some specimens wholly black; from the frontlet feathers to the point one inch and an eighth, tarsi five eighths.

Adult male with the bill reddish-yellow; forehead white; hind head black-a spot of the same color before the eye; upper parts pale bluish-gray; tail pale ash and forked; first three primary quills, with their outer webs, black-a portion of their inner webs the same color, margined with white, of which color is the entire lower plumage; legs and feet reddish-yellow. Young, in summer, 
with the forehead brownish-white, a dusky band passing from behind the eyes on the occiput-a patch of the same color on the shoulders of the wings; back and wing-coverts pale grayish-brown, the feathers marked with darker brown; lower parts white.

In plumage, this species bears a strong resemblance to the Common Tern, with which it associates. During summer it is common along the Atlantic districts, its breeding range being no less extensive. It arrives on the shores of Long Island in the month of May, and retires south in Autumn. It feeds on various species of insects, as well as on small fish. Length nine inches and a half, wing six. and five-eighths.

\section{STERNA DOUGALLI-MONT.}

ROSEATE TERN.

\section{Sterua Dongalli, Temm.}

Roseate Tern, Nutt. Man.

Roseate Tern, Sterna Dongalli, Aud. Orn. Biog.

Specific Character-Pill black, tail deeply forked, the lateral feathers extending about three inches beyond the wings. Bill from frontlet feathers to the point, one inch and five-eighths, tarsi, threequarters. Adult male with the upper part of the head and occiput black; sides of the head and hind neck white; upper parts pale bluish-gray--the tail lighter and deeply forked, the outer feathers being $4 \frac{1}{2}$ inches longer than the middle feathers, and extending about three inches beyond the wings; outer vane of the first quills black ; a band of the same color on the inner web next to the shaft, increasing in width, and becoming lighter in color on the inner quills; fore neck, breast, abdomen, and sides of the body rose color, which almost entirely disappears soon after death; feet bright red. Length fourteen inches and three quarters, wing nine and a quarter.

In this vicinity it is not common. According to Mr. Audubon, it is abundant on the Florida Keys, where it breeds. With us, this elegant Tern is occasionally observed in company with the Common Tern, from which it is easily distinguished by its black bill, deeply forked tail, and the lower parts of the body being of a delicate rose color. 


\section{STERNA NIGRA-LINN.}

\section{BLACK TERN.}

Sterna Nigra, Bonap. Syn.

Sterna Nigra, Black Tern, Sw. \& Rich.

Black Tern, or Stern, Nutt. Man.

Black Tern, Sterna nigra, Aud. Orn. Biog.

Specific Character-Bill black, slender, from frontlet feathers one inch, tarsi nine-sixteenths, tail slightly forked. Adult male with the head, neck, breast, sides of the body and abdomen black; lower tail c.cverts white; upper parts and tail, dark bluish-gray; shafis of the quills brownish-white, the outer lighter, their tips blackish-brown-the wings extending about two inches beyond the tail ; shoulders, wings, and lower wing coverts bluish-gray; feet reddish-brown. Young with the forehead, throat, and neck, brownish-white; crown and occiput dısky; breast and abdomen white; the sides of the tody and lower wing coverts bluish-gray-upper wing coverts darker, mottled with brown. Length nine inches, wing eight and a quarter.

" This species is common to both continents. In America, its migrations extend to the interior of the Fur countries, where, according to Dr. Richardson, it is known to breed; and in Europe it is met with as far as Iceland." Along the coasts of the middle Atlantic districts, it is not very common. It seems to prefer the marshes not far from the sea. It visits annually the marshy grounds lying in the vicinity of the sea coast of New Jersey ; and according to my observations, is more numerous on the meadows in the neighborhood of the city of Newark. On Long Island it does not occur in large numbers, though by no means rare, as almost every season a few are observed flying over the necks of land in pursuit of insects, and fishing on the creeks and mill-ponds. It seems, howerer, to prefer feeding on the inhabitants of the air to those of the water, which are not altogether neglected in making up its bill of fare.

The Black Tern, like the rest of its tribe, bas great powers of wing, and though apparently delicately formed, it is strong and muscular. It is active in pursuit of its prey, and displays the same timidity of disposition, except when defending its young, for which 
all of this class are noted. The eggs of this species $I$ have not been able to find, nor have I been informed of their occurring within the limits of our locality. The young have been found in the Newark meadows in August, by Mr. Brasher. His indefatigable exertions in this and other localities in the vicinity of New York, in pursuit of its eggs, have been thus far unsuccessful. I would not be surprised to hear of its being found breeding along the rush-covered margins of the streams and ponds on Long Island.

'The flesh of the Black T'ern, from its feeding chiefly on insects, and collecting its food in the vicinity of fresh water, is better tasted and more palatable than the others of this Genus, which feed almost entirely on marine productions.

"In England, where this conspicuous Tern is common, it is described as possessing the same manners and customs as with us. It is found on the fenny parts of Lincolnshire and Cambridgeshire-is plentiful about the reedy pools on Romney Marsh, in Kent, where it first appears in the latter end of April, or beginning of May, and breeds in the sedgy places on the verge of the pools-and though very near the sea, is rarely seen on the shores till after the breeding season, and then not commonly. It lays three or four light olive brown eggs, blotched with black."-Montagu's Ornithological Dictionary.

\section{S'TERNA ANGLICA-MONTAGU.}

\section{MARSH TERN.}

Sterna aranea, Wilson.

Sterna aranea, Bonap.

Marsh Tern, Sterna anglica, Nuttall.

Marsh or Gull-billed Tern, Sterna anglica, Aud.

Specific Character-Bill black, high, from the frontlet feathers to the point one inch and a half, at base half an inch high; length of tarsi one inch and an eighth; the upper and hind part of the head black; the upper parts pale grayish-blue; tail forked, the feathers white; tarsi and feet black; the wings extend about two inches beyond the tail. Length fourteen inches, wing twelve.

This species can be readily distinguished by its short, strong and 
black bill. Wilson, who met with specimens at Cape May, informs us that on the salt marshes it breeds, laying three or four eggs of a greenish-olive color, spotted with brown, on the dry drift grass, without any appearance of a nest. "The food of this species, during summer, consists chiefly of large black spiders, which abound on the salt marshes. Their voice is sharper and stronger than that of the common Tern; the tail much shorter and less forked. They do not associate with others, but always keep in small parties by themselves." In this vicinity it is rare; during my excursions I have never met with it.

\section{STERNA TRUDEAUII-AUD.}

\section{TRUDEAU'S TERN.}

Specific Character-Bill at base yellow, anterior to the nostrils black; toward the end yellow, length from the frontlet feathers to the point one inch and a half; length of tarsi seven-eighths of an inch; tail deeply forked, the lateral feathers exceeding the next, longest three inches; wings long, pointed; general plumage light grayish-blue. Adult with the head, upper tail coverts, throat, rump, shoulders, and lower wing coverts white; a dusky spot anterior to the eye, and a band of the same color behind the eye; upper and lower parts light grayish-blue, the tail feathers lighter; tail deeply forked, the lateral feathers about even with the wings; quills hoary, the outer vane of the first primary quill dusky-a band of the same on the inner web next the shaft, the next more faintly marked with the same; the outer six quills, with their inner webs toward their margins (which are white) dusky; feet orange. Length sixteen inches, wing eleven and a lialf.

The discovery of this species is due to Doctor Trudeau, who shot several specimens at Absecom Beach, Egg Harbor. It is comparatively of recent discovery, and does not seem to be a very abundant species. The only Ornithological work in which I have seen it noticed, is the Synopsis of Mr. Audubon. The young I have never seen, and with us the occurrence of the adult is not frequent. 


\section{STERNA CAYANA-LATHAM.}

\section{CAYENNE TERN.}

Sterna cayana, Bonap.

Cayenne Tern, Nuttall.

Cayenne Tern, Stema cayana, Aud.

Specific Character-Bill orange, very stout, along the gap three inches and a half; upper mandible much rounded; wings exceedingly long, extending beyond the tail about four inches and a half. Adult with the bill stout, carmine; upper part of the head and occiput greenish-black"; back and upper surface of the wings light grayisl-blue; neck and lower parts white; feet black. Length nineteen inches, wing fifteen and a half. Young with the upper parts and tail feathers deeply tinged with yellowish-brown, the feathers with black bands toward their ends.

According to Mr. Audubon, this the largest of all our Terns, breeds on the Tortugas, and extends its migrations as far as Labrador. In the Fauna Borealia Americana it is not noticed. Mr. Nuttall does not speak of its occurring on the coast of Massachusetts, It escaped the observations of Wilson, and is not generally supposed to frequent the coasts of the Middle States. To the shores of Long Island it is not common-although, as we will show, we have an undoubted right to enumerate it with the long list that we are preparing for that locality. The cabinets of Messis. Lawrence and Brasher contain specimens that were shot at Islip. Mr. Bell has received a number of specimens procured on various sections of the southern coast of Long Island-one of which, a fine aduIt male, was shot last summer at Raynor South, and I have now before me a specimen obtained at Moriches. Of its habits I can say but little, further than it frequents the sea shore, and feeds on marine productions. Its superiority in point of size, as well as its unusual [for this class of birds] strong bill, is at all times a sufficient specifie character. "It inhabits the tropical seas of America, is common on the coasts of the Sonthern States, and is abundant on the Florida Keys, where, with many species of Terns, as well as Gulls, it breeds." The flesh of the Gulls and Terns not 
being considered suitable for the table, they escape the torture to which birds of a more delicately-flavored flesh are subjected. Still, they are not entirely exempt from persecution, as there are those who fancy a Gull's egg an exceedingly delicate morsel.

The Florida Keys, which are the breeding places for great numbers of Gulls and Terns of various species, are resorted to annually by "eggers,"-persons who make a business of collecting the eggs of these marine birds. On visiting this great depot, they rise in such vast bodies as to darken the air, at the same time almost deafening the intruder with their shrill cries. The collectors, in order that they may take only those that have been recently laid, drive off the birds, and remove or break all the eggs within a certain space. In a few days the collectors return, and all the eggs found within the prescribed limits are known to be fresh, and taken to the West Indies, where they are by many esteemed highly.

On the coast of Labrador, which is the breeding place for numerous species of water bird, this business of collecting birds' eggs is carried to a greater extent. I am informed that in the eastern towns and cities, small vessels are annually fitted out expressly for that purpose. Large numbers are destroyed by being broken and trampled on, besides those taken away; and in this manner there are more birds destroyed in embryo-if I may so term it-in one season, than all the sportsmen in christendom would destroy with the gun. The fishermen, I am told, make free use of the eggs. Those of somespecies, they say, are exceedingly well tasted, affording palatable and nourishing fare. 


\section{GENUS LARUS-LINN.}

GLLLS.

[Bill straight, hard, compressed, of moderate length, with the point rather sharp ; neck of moderate length, body rather full, wings long and pointed; tail usually even, of twelve feathers; feet rather slender; hind toe small; middle toes about the same length as the tarsi.]

\section{LARUS ARGENTATUS-BRUN.}

\section{HERRING OR SILVERY GULL.}

\section{Larus argentatus, Bonap.}

Herring Gull, Larus argentatus, Nuttall.

Herring Gull, Larus argentatus, Audubon.

Specific Character-Bill stout, yellow, with a reddish-orange patch toward the end of the lower mandible; from the frontlet feathers to the end two inches and an eighth; length of tarsi two and a half. Adult with the head, neck all round, lower parts, rump and tail feathers, pure white; back and wings light grayish-blue; the outer six quills blackish-brown toward the end, the larger portion of the first being of that color, which is gradually reduced to a small spot on the sixth; a patch on both webs of the first quill, near the extremity, which, with the tips of all, are white; on the second quill a much smaller patch of the same color, which is confined to the inner web; other parts of the webs commencing at the base, light bluish-gray, their terminal portion lighter; upper surface of the shafts blackish-brown, the lower white. Winter dress, the head and neck all round mottled and streaked with grayish-brown. Young in winter, bill brownish-black; head and lower plumage grayishbrown; úpper parts mottled with dull white and yellowish-brown; tail coverts barred with dull white and brown; quills and tail brownish-black, the lateral feathers irregularly barred with white ; tips of the primaries and tail feathers dull white. In this plumage it is the "Gray Winter Gull" of our gunners. Length twenty-five inches, wing eighteen.

Most of this class of birds, like the Terns, resemble each other in all the different stages of plumage, and alike with them, are subjected to great changes, dependent on age and season. Fourteen 
species are known to inhabit North America, four of which, viz. L. Rossii, Franklinii, ebernus, and minutus, inhabit the high northern latitudes. L. occidentalis is a denizen of the western side of the continent. Eight species are entitled to a place among "The Birds of Long Island;" and according to Mr. Audubon, L. leucopterus, ranges during winter from New York to Nova Scotia, but in our locality I have not met with it.

The Herring Gull is quite a common species, and is found along the whole extent of the Atlantic coast. I have also observed it on Lakes Ontario, Erie, Huron, and Michigan, and have met with it on streams in the interior. At low water, with other species, it resorts to the bars and shoals, sometimes congregating in such large numbers, as to line the shore for a considerable distance. At the influx of the tide, it passes most of its time in the air, flying around in wide circles, and at times to a very great height. At other times it is observed following the shoals of fry, on which it depends for the greater portion of its support. As is the case with the rest of this class of birds, it is incapable of diving, and can only secure its prey when at the surface, immersing only the head and neck.

\section{LARUS ATRICILLA-LINN.}

\section{BLACK-HEADED OR LAUGHING GLLL.}

Black-headed Gull, Larus ridibundus, Wils. Amer. Orn. Larus atricilla, Bonap. Syn.

Black-headed Gull, Nutt. Man.

Specific Character-Bill deep carmine, from the frontlet feathers to the end, one inch and three-eighths, length of tarsi, one inch and three-fourths. Adult male with the head and upper portion of the neck, all around, pale bluish-black; lower part of the neck, rump, tail, feathers and eyelids, white; the lower parts of the same color, with a tinge of rose color on the breast, which fades soon after death; back and wing-coverts, grayish-blue; outer primaries and their shafts blackish-brown, inner grayish-blue, toward their ends the same as the outer all tipped with white, more distinctly so on the inner; secondaries broadly tipped with the same; feet dark-red.

Autumnal dress. Head white, intermixed with dusky; hind neck and sides of the neck, light grayish-blue; throat, breast, and abdo- 
men, white; rump and tail-feathers, white, tinged with light bluish. gray; bill and feet greenish-black; in other respects the same as in spring. This description was taken from an adult specimen shot in the early part of September. Length seventeen inches, wing twelve inches and a quarter.

This handsome Guil arrives on the shores of Long Island in the latter part of April. It is quite a common species, and well known by the name of Laughing Gull, so called from its notes resembling the coarse laugh of a human being.

During summer it is observed along the eastern coast of the United States, but as it does not occupy a place in the Fauna Boreali Americana, we may infer that its migration does not extend far be. yond the limits of the Union. It breeds on Long Island. The eggs, which are three in number, of a brownish color, marked and blotched with a blackish-brown, are found on the low islands in the South Bay. They are dropped on the grass with but little or no preparation of a nest; like the rest of the Gulls it is exceedingly watchful and timid, though very courageous when defending its young. It is frequently observed fishing and making ærial excursions in company with (S. hirurdo) the Common Tern.

\section{LANUS BONAPARTII-RICHARDSON.}

BONAPARTE'S GULL.

Larus capistratus, Bonap. Syn.

Larus Bonapartii, Bonapartian Gull, Sw. \& Rich.

Bonapartian Gull, Nutt Man.

Bonapartian Gull, Larus Bonapartii, Aud. Orn. Biog.

Specific Character-Bill black, rather slender; from the frontlet feathers to the end about one inch and an eighth, tarsi one and a quarter; outer vane of the first primary black. Adult with the head and upper portion of the neckall round grayish-black; lower part of the neck, under parts, rump, and tail feathers pure white ; back and wings light grayish-blue; outer web of the first quill black, the inner web, with the shafts of all, and outer vanes of the second, third, and fourth, white, the inner webs as well as both webs of the inner quills of the same color as the back-those of the inner 
much darker; the ends of the primaries and the ends of their shafts black, their tips white, of which color are the eyelids; feet carmine. Length fourteen inches and a half, wing ten and a quarter. Young with the forehead white; crown and upper portion of the hind neck, mottled with dusky; other parts of the neck white, tinged with grayish-blue; lower parts white; tail the same color, with a terminal band of black, which disappears after the second moult; neck and wings grayish-blue, with a few spots of brown on the latter; a spot of dusky on either side of the neck, which is a strong distinguishing character for the young of this species.

In plumage this species resembles L. atricilla, but differs ma. terially in size as well as in the color of the bill. With us, during some seasons, the young are quite common, though the adult is by no means so. It is a handsome and strongly marked species, and, when flying, utters a peculiar shrill and rather plaintive cry.

\section{LARUS ZONORHYNCHUS-LINN.}

\section{RING-BILLED GULL.}

Larus canus, Mew or Common Gull, Sw. \& Rich.

Ring-billed Mew Gull, Nuttall.

Common American Gull, Larus Zomorhynchus, Aud.

Specific Character-Bill greenish-yellow; anterior to the nostrils a broad black band; from the frontlet feathers to the point one inch and a half; length of tarsi one and three quarters. Adult with the back and upper surface of the wings light grayish-blue, the first six quills black toward their ends; the first and second almost entirely of that color, which is reduced to a narrow bar on the sixththe first and second having a white spot about an inch and a half long, near their tips; the terminal portion of all the others, and the ends of the scapulars white, of which color are the tail feathers and the lower parts. Young with the lower parts dull white, mottled with grayish-brown; upper parts with large blackish-brown spots ; outer primary quills black, the tips slightly margined with white. Length twenty-nine inches, wing fourteen and a quarter.

This Gull is said to breed in Arctic America, and retires southward as the winter sets in, at which season it is common along the whole extent of the coast of the United States. 


\section{LARUS TRIDACTYLUS-LINN.}

KI'T'TIWAKE GULL.

Larus tridactylus, Bonap. Syn.

Larus tridactylus, Kittiwake, Sw. \& Rich.

Kittiwake, Nuttall.

Kittiwake Gull, Larus tridactylus, Aud. Orn. Biog.

Specific Character-Hind toe wanting, substituded by a minute knob; bill rather strong, greenish-yellow; head, neck all around, lower parts, tail-feathers, and rump, pure white; wings light gray. ish-blue; the outer vane of the first quill blackish-brown; the ends of the outer five primaries blackish-brown-this color occupying about two inches and a half on the first two, gradually lessening on the next three, the tips of which are white; feet black. Length eighteen inches, wing eleven inches and a half.

In winter, the head and neck are shaded with bluish-gray.Young, with the bill dusky; a crescent of the same color before the eye; wings mottled with blackish-brown-outer quills the same color, with a portion of their inner webs white.

In this vicinity, the Kittiwake is not very common. It is more so on the coasts of the Eastern States. According to Dr. Richardson, it abounds in the interior of the Fur Countries, on the coast of the $\mathrm{Pa}$ cific, and also on the shores of the Arctic Seas, where it breeds.

\section{LARUS MARINUS-LINN.}

GREAT BLACK-BACKED GULL.

Black-backed Gull, or Cobb, Nuttall.

Great Black-backed Gull, Larus maribus, Aud.

Specific Character-Bill along the gap three inches and a half, much hooked and stout, tarsi three and a half inches. Adult male with the head, neck, lower parts, rump, and tail feathers, white; back and wings blackish-purple; edges of the wings and the extremities of all the quills white; a broad band across the ends of the second, third, fourth, and fifth primaries; bill robust, gamboge yellow, with a patch of carmine toward the end of the lower man- 
dible; feet flesh colored. Young, with the upper parts marked with brownish-black, dull white, and pale brownish-gray; lower parts grayish-white, as are the head and neck; tail white, with a black spot toward the end-the middle feathers barred with lighter toward the base; primary quills blackish-brown-their tips lighter; bill brownish.blaek.

The Black-backed or "Saddle Back Gull," is said to be an inhabitant of various parts of the northern shores of the American continent. At the approach of winter, it migrates to the extreme southern part of the United States, where, according to Mr. Audubon, it is not uncommon. With us, it is not in general very abun. dant, though at some seasons considerable numbers are observed along the sea coast of Long Island.

The Black-backed Gull, like others of the Genus, feeds indiscriminately on fish, and various productions of the sea ; and it is said by Montagu, that the Asterias, or Star-fish, contribute largely to its support. This species is extremely ravenous, and when pressed by hunger, attacks smaller Gulls; and it is also said to descend upon hares and grouse; when other food cannot be easily obtained, it frequents the shore, and feeds upon dead fish and other substances thrown up by the sea. It is exceedingly wary, and difficult to obtain; and when not in quest of food, soar to a great height in the air. Its flight is majestic, and performed in wide circles, and from its safe and lofty position, its loud and raucous cry is often heard.

\section{LARUS SABINA-SABINI.}

\section{FORK-TAILED GULL.}

Larus Sabini, Fork-tailed Gull, Sw. \& Rich.

Fork-tailed Gull, Nuttall.

Fork-tailed Gull, Larus Sabini, Aud.

Specific Character-Bill black, rather slender, with the upper mandible curved at point; tail deeply forked. Adult with the head and upper part of neck blackish-gray, bounded by a collar of pure black; back and wings bluish-gray; primaries black, with 
their tips white, as is terminal portion of the secondaries; lower parts and tail feathers pure white. Length thirteen inches and a half, wing eleven.

A specimen of this elegant Gull was shot at Raynor South in the month of July, 1837, and I am not aware that any other has ever been observed in this vicinity. It is said to breed along the coast of the Arctic seas, and in Newfoundland. "This interesting species of Gull was discovered by Captain Edward Sabine. It was first seen on the 25th of July, at its breeding station on some low rocky islands, lying off the west coast of Greenland, associated in considerable numbers with the Aretic Tern, the nests of both birds being intermingled. It is analagous to the Tern, not only in its forked tail and choice of breeding place, but also in the boldness which it displays in the protection of its young."-Fuuna Boreali Americana.

\section{LARUS GLAUCUS-BRUNN.}

GLAUCOUS GULL.

Larus Glaucus, Bonap.

Larus Glaucus, Burgomaster Gull, Sw. \& Rich.

Glaucus Gull, or Burgomaster, Nuttall.

Glaucus Gull, or Burgomaster, Larus glaucus, And.

Specific Character.-Bill stout, compressed, gamboge yellow, with a carmine patch toward the end of the lower mandible; from the frontlet feathers to the end two inches and a quarter, tarsi two and a half. Adult with the plumage pure white, "excepting the back and wings, which are grayish-blue ;" edges of wings, and the quills toward the end white. Young, white, the upper parts slightly tinged with pale yellow, lower parts with brown; feet flesh color. Length of young twenty-seven inches, wing seventeen and three quarters.

This large and powerful Gull is chiefly confined to the northern part of the liemisphere. The adult rarely visits the United States, and then only in winter, and I am not aware that it has ever been observed on Long Island; and it is but seldom that the young occurs with us. "It is notoriously greedy and voracious, preying not only on small fish and birds, but on carrion of every kind. One 
specimen, killed on Captain Ross's expedition, disgorged an Auk when it was struck, and proved, on dissection, to have another in its stomach." - Fauna Boreali Americana.

"Mr. Hutchins speaks of a pure white Gull, which breeds on the Albany River, as large or larger than the Ivory Gull, being twenty seven inches and a half in length, five feet from tip to tip of the wings, and weighing 2 pounds, its bill and legs flesh colored." $I b$.

I am inclined to consider it the young of L. glaucus, as I have in my possession an immature bird, which I recognise as the young of the present species, [L. glaucus, ] which was shot on the south shore of Long Island. It agrees with the bird mentioned by Mr. Hutchins excepting that the abdomen in my specimen is faintly tinged with brown, and the upper parts faintly tinged with pale yellow or cream color, without any trace of the grayish-blue mantle, and the absence of spots or streaks of any kind, the general appearance being white.

\section{GENUS LESTRIS-ILLIGER.}

\section{JAGERS.}

[Bill rather shorter than the head-hard, strong, hooked; head rather large ; neck thick; body full; wings long, broad, pointed ; tail rather long, consisting of twelve broad feathers, middle pair extending beyond the others; feet rather slender; hind toe small.]

\section{LESTRIS PARASITICUS-LINN.}

\section{ARCTIC JAGER.}

Lestris Buffonii, Bonap. Syn.

Lestris parasiticus, Sw. \& Rich.

Arctic Jager, Nuttall.

Arctic Jager, Lestris parasiticus, Aud. Orm. Biog.

Specific Character-Adult bill, from the frontiet feathers to the point, one inch and one eightl, length of tarsi one inch and a half, tail rounded, the middle pair of feathers produced tapering to an acute point; young with the basal part of weos yellow. Adult male with the crown, nape, quills, and tail, pitch black; back, scapulars, and lesser wing coverts blackish-brown, with a tinge of gray; shafts of the tail, and quills whitish, except on their tips; head beneath the level of the eye; neck above and below, and breast, straw yellow; anterior part of the belly whitish-posterior part, flanks, and under tail coverts brownish-gray; interior of the wing blackish-gray. Bill 
livid; its tip, the knee joint, and feet blackish; tarsi blotched with yellow; wings longer than the lateral tail-feathers; bill having a straight commissure to past the nostrils, where it, is curved in both mandibles; edges of the upper mandible obsoletely notched; tail rounded, exclusive of the middle pair of feathers, which are nearly an inch wide at the base, and taper gradually to within three inches of their tip-thence they are narrowly linear, or slightly tapering, the extreme tip becoming suddenly acute-they project half a foot beyond the others; tarsi slender, protected anteriorly by crescentic scutelli, reticulated behind with minute conical and rather acute scales; length of central tail feathers 12 inches.-Fauna Boreali Americana, page 431.

The only adult specimen in my possession is a female shot at Oyster Bay South. The plumage agrees with the description given of the male, but has of the tail feathers about three inches shorter. Length of female twenty inches, wing twelve and a half.

Young, with the head and neck all around pale yellowish-brown, streaked with dusky; lower parts grayish-white, closely barred with dark brown ; under tail coverts barred with brownish-red and black ; upper tail coverts black, broadly tipped, and some of the feathers spotted with brownish-red; fore part of back, scapulars, and wing coverts tipped with pale yellowish-brown; wings and tail black; tail feathers broad and rounded, the middle pair pointed, and projecting beyond the rest about half an inch; shafts of the quills and tail feathers white, their terminal portion black. The legs, posterior part of webs and toes dull yellow, anterior parts black. Length of female in my possession, 20 inches, wing $12 \frac{1}{2}$.

A specimen of this Jager, which proved to be a young male, was shot in the month of October, 1842, on Gowannus Bay. It was observed Aying about near the surface of the water, as if in pursuit of fish, of which, on dissection, however, no parts were found-its stomach being filled with tallow.

On the coast of Long Island the Arctic Jager is not commonthough of more frequent occurrence than L. Pomarinus. It inhabits during summer the high latitudes, where it breeds-and according to Mr. Audubon, ranges during winter off the coast as far as the Gulf of Mexico. 


\section{LESTRIS POMARINUS-TEMMINCK.}

\section{POMARINE JAGER.}

Lestris pomarinus, Bonap.

Lestris pomarinus, Sw. \& Rich.

Pomarine Jager, Nuttall.

Pomarine Jager, Lestris pomarinus, Aud.

Specific Character-Middle pair of tail feathers retain their length throughout, and are rounded at the tip. Adult with the "bill dark brown, tipped with black; legs black; plumage of the nape, long; tapering, acute; head, neck, under eyelid, a patch at the corner of the mouth, back, wings, and tail, brownish-black-flanks and sides of the breast blotched with the same; shafts of the quills and tail feathers white, exeept at their tips; neck straw yellow; auriculars, chin, throat, breast and belly, white, vent and under tail coverts blackish-brown; tail slightly rounded, independent of the middle pair of feathers, which project three inches; these latter retain their breadth throughout, are rounded at the tip, and are twisted so that their vanes incline obliquely toward each other. Length twentyone inches, wing fifteen." An immature specimen now before me, shot on the south shore of Long Island, has the upper half of the legs yellow, lower half, feet, and webs, black; fore part of the head, crown, back, wings, and tail, blackish-brown; lower parts grayish-white; fore part of neck and the sides of body barred with blackish-brown.

The Pomarine Jager is said to inhabit during summer the high northern latitudes, migrating to the more temperate parts in winter, at which season it is occasionally observed along the sea coast of the Eastern States. Its occurrence on Long Island is exceedingly rare, and from not having an opportunity of observing its habits, I cannot do better than give the remarks as stated by Dr. Richardson. "The Pomarine Jager, or Gull-hunter, is not uncommon in the Arctic seas and northern outlets of Hudson's Bay, where it subsists on putrid fish, and other animal substances thrown up by the sea, and also on the matters which the Gulls disgorge when pursued by it. It retires from the North in the winter, and makes its first appearance at Hudson's Bay in Maine, coming in from seaward. The Indians abhor it, considering it to be a companion of the Esquimaux, and to partake of its evil qualities." 


\section{LESTRIS RICHARDSONII.}

\section{RICHARDSON'S JAGER.}

Lestris Richardsonii, Richardson's Jager, Sw. \& Rich.

Richardson's Jager, Nuttall.

Richardson's Jager, Lestris Richardsonii, Audubon.

Specific Character-Bill greenish-black, from the frontlet feathers to the point one inch and one-sixteenth; length of tarsi one inch and nine-sixteenths. Upper plumage blackish-brown, lighter on the hind neck; lower parts hair brown; quills and tail black; shafts of the primaries white, their tips black; shafts of all the tail feathers white; at base along the middle dark brown, toward the end black; length of the middle pair of tail feathers eight inches and three quarters, toward their ends abruptly narrowing, pointed, aud are extended two inches and seven-eighths beyond the others, which are truncated; legs and feet black. Length nineteen inches and a half, wing twelve and three-eighths.

The above description is taken from a specimen shot in the vicinity of Islip, and is the only individual which I have known to be procured on Long Island. It agrees with the figure given of L. Richardsonii, in the Fauna Boreali Americana, from which we extract the following:

"This Jager breeds in considerable numbers in the barren grounds at a distance from the coast. It feeds on shelly molusca, which are plentiful in the small lakes in the Fur countries, and it harrasses the Gulls in the same way with others of the Genus."

On referring to Ornithological works, we find the descriptions given of this class of birds very unlike. The Jagers, alike with the Gulls and Terns, at certain stages appear very different

It is difficult to procure them, and perhaps from a sufficient number of specimens not being obtained, is the cause of their not being more clearly defined. 


\section{GENUS PUFFINUS-BRISS.}

\section{SHEARWATER.}

[Bill rather slender, as long as the head, much compressed toward the end -about as deep as broad at the base-nearly straight, being slightly recurved, with the tips decurved; head rather large, obiong; neck rather short; hody moderate ; wings very long, narrow-the first quill longest; tail of moderate length, graduated, of twelve rounded feathers; feet rather large ; tarsi compressed, of moderate length; tibia bare above the knee; anterior toes long, slender.]

\section{PUFFINUS CINEREUS-LATHAM. \\ CINEREUS PUFFIN, OR WANDERING SHEARWATER. \\ Puffinus cinereus. Bonap. \\ Cinereus Puffin, Nuttall. \\ Wandering Shearwater, Puffinus cinereus, Audubon.}

Specific Character-Bill yellowish-green, the tip brownish-black ; length from the frontlet feathers to the end one inch and three quarters; tarsi two inches. Adult with the upper parts deep brown; the hind ncck paler, and tinged with gray; primary quills and tail brownish-black; lower parts grayish-white; webs and claws yellowish flesh color. The cabinet of the Lyceum of Natural History, New.York, contains a specimen which has the head, hind neck and upper parts deep brownish-black; quills and tail black; lower parts light brown. Length twenty inches, wing thirteen.

On the coast of Long Island the occurrence of this bird is extremely rare. The cabinet of Mr. Brasher contains a handsome specimen that was procured at the Narrows. It was taken by a fisherman, who observed it feeding on the offal of fish that he was cleaning. Not having a gun, and desirous of capturing this rare bird, he resorted to the ingenious stratagem of attacking to the end of a line, a fish-hook-and by letting it drift among the offal, upon which it was intently feeding, it became fasiened to the web, and by this means the prize was secured alive. It proved to be a fine adult male. Its stomach contained a few particles of shells, and doubtless its boldness was the effect of extreme hunger.

The Cinereus Puffin, or Wandering Shearwater, "inhabits the sea throughout the globe. Common between the banks of Newfoundland and the United States, in the Mediterranean, \&c." 


\title{
PUFFINUS ANGLOEUM- $R A Y$.
}

\author{
MANES SHEAENTEEE.
}

\author{
Fuffinus anglonim, Bonan. \\ Shearvater Detrel, Nuttall

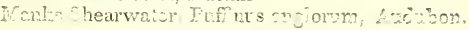

Specific Characior-Eill green'sh-'ilac', very s'ender, length one inch and three cquarters; tarsi cbout one inch and three quar-

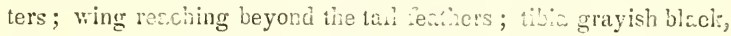
marked with cull orange, weibs pais yeilow; Lyper parts glossy black; beneath wiite. Length ffeen izchos.

This, like the preceding, is witi us rn accice:tai visitor. In its rabits, it is nearly allied to the Ietreis. It spends most of its tine at sea, whe is said to inhabit the Lurcho sea of both continents.

A.ccording to I. Andubon, this species is act uncermon of the coast of Maine ciuring surrer. Ireeds cr Sa'le island, Nova Scotie, and renges at times to grent ästrnces sezw crí.

"In the Northem Eritish Istonds it is common during the breed. irg season. It the sctith err of the isie of rer lics a little islet, civided from Men by nerrow chonnel, caliew the alf of Man, on which are no habitaticns, but cniy $e$ cottage cr two, lately built. This islet is fuli of rabbits, which the ruffrs, coming yearly dislodge, and builc in their turows They loy lut one egg. The old ores, carly in the momirg, at the breals of ay, leave their nests and ycurg, ari the isiarc itself, anci spend the ciay in fishing et sen--nerer returning except at twilight. They feed tho yourg ones from the conterts of their loaded st machs, during the night. They become extremeiy fat, and are takon and salted dow? for keeping and permitted by the Fomish Church to be eaten in Lent."-W Perwick's British Biräs. 


\section{PUFFINUS OBSCURUS-LATHAM.}

\section{DUSKY SHEARWATER.}

Puffinus obscurus, Bonap.

Dusky Petrel, Nuttall.

Dusky Petrel, Puffinus obscurus, Audubon.

Specific Character-Bill slender, light blue, the tip black, from the frontlet feathers to the point one inch and three-sixteenths; length of tarsi one inch and a half; sides of the head beneath the eye, sides of the neck and the lower parts white; upper parts black; wings reaching to the end of the tail, which is rounded. Length twelve inches, wing seven and seven-eighths.

This is another of those stragglers that occasionally visit the coast of Long Island. In plumage it is closely allied to the preceding, from which it materially differs in size, being about three inches less. It is said to inhabit throughout the temperate and warm seas -never to the North. Abundant during summer in the Gulf of Mexico, and off the coast eastward to Georgia.-Audubon.

\section{GENUS THALASSIDROMA-VIGORS.}

PETREL.

[Bill shorter than the head-slender, compressed, at the end hookednostrils contained in a single tube-head small, rounded above-neck shortbody slender-wings long-tail emarginate, of twelve feathers-feet slender, webbed.]

\section{THALASSIDROMA WILSONII-BONAP. WILSON'S PETREL.}

Stormy Petrel, Procellaria pelagasia, Wilson.

Wilson's Stormy Petrel, Nuttall.

Wilson's Petrel, Thalassidroma Wilsonii, Audubon.

Specific Character-Bill black, from the frontlet feathers to the point, seven sixteenths of an inch, length of tarsi, one inch and threesixteenths. Adult male with the feet black; a large portion of the webs yellow; plumige dark grayish-brown, darker on the back; wings and tail feathers brownish-black; rump, sides of the abdomen and outer lower tail-coverts, white-secondaries tipped with the same; tail even. Length six inches and three-fourths, wing five inches and seven-eighths. 
This species, familiar to mariners by the name of "Mother Cary's Chickens," is found on almost every part of the Atlantic Ocean. They are met with far at sea, and are not uncommon off Sandy Hook, within sight of land-and occasionally stragglers are seen coasting along the shores of Long Island.

$\Lambda$ mong sailors, many superstitious notions exist concerning these ocean wanderers. By some, they are supposed to be connected with evil spirits, and have an agency in producing storms. I had an excellent opportunity of observing the manners of these swallows of the ocean, when maling an excursion to sea in a Pilot Boat. The vessel being low, and by throwing over small pieces of fat, which they seized with avidity, I was enabled to keep them so near, that I could distinctly trace their plumage, as well as observe their manners. Before losing sight of land, we fell in with these ærial mariners, who during the whole trip, followed in the wake of the vessel, as if imploring for a contribution to the scanty pittance of fare they glean from the foaming surges. At sea, it is a pleasing sight, when the eye wanders from the floating prison, to see these sprightly little voyagers coursing over the rough and broken waves, as regardless of danger as the finny inhabitants below.

The Petrel is capable of very rapid, as well as protracted flight. At times, it is seen shooting by the vessel as if it were at anchor, while at the same time it is moving at a rapid rate. When wearied, they rest on the water. At such times we see them with outspread wings, standing or running on the majestic billow, with apparent facility and ease-the lightness of its body rendered more buoyant by the action of its wings, and its feet being webbed and constantly in motion, assists it in this singular performance. Its note, which is usually quite low and feeble, is, during boisterous weather, more harsh and oftener repeated. Shortly before, and during a gale, it flocks nearer the vessel-hence the sailors' superstitious dread.Among other absurdities connected with this bird, is the vulgar notion that it carries its eggs under its wings, hatching them while on the water.

"The Stormy Petrel, or Mother Cary's Chicken, breeds in great numbers on the rocky shores of the Bahama and Bermuda Islands, and in some places on the coast of East Florida and Cuba. They 
breed in communities, like the Bank Swallow, moking their nests in the holes and cavities of rocks above the sea, roturning to feed their young onle during the night, with the sunerabundant oily frod from their stomachs. - Wilson.

Mr. Audubon also infrmz vs that it brood in vast numbers from Maine to Baffin' $\mathrm{Ra}$. From the natres of its food, which is small fish and barna"s in a h is ment and nily "Although unpalatable, it is aid that tho noti of Torm tand convert them in. to domestic use, by drawin o win? lonnthwice through their bodies; they make their nily car ? ? eggs of this spocien are raid a ho hroe- he colnr white.

The Petre! in nom driven in, as it oc. casionally happene, $b \ldots$ Shrt in August, 812 , I rocoind s. 11 ming fron Mr. S. F. Baird, re-

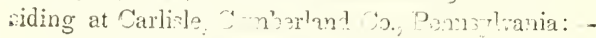

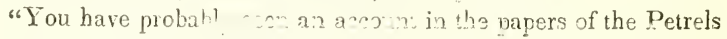
which had been drima inland $b$, the ron of 1 gust. They were nearly a!l the Forli-tailed Dord, T alasidro na Leachii. I saw about half a dozen snecin killed noar i Tasington. There were

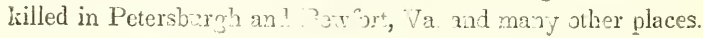

ธ. II. BAIRD."

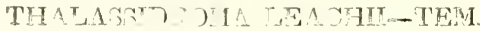

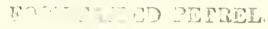 \\ Thalassidroma Le $32.7 \%$ \\ Fork-tuiled St

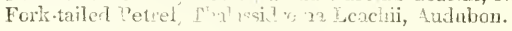

Specific Charactor ." and fasi ilack; fron the frontlet feathers to the poini 1i. andin: of a 1 inch, length of tarsi seven-eighths; tail forked; plunago cark grajih-brown; wings and tail feathers brownish-black; mallor wing coverts and inner secondaries light grayish-brova ; rump and ides of te abdomen, and upper tail corests white. Iongin eig inc er and three quarters, wing six.

This, lile iho procins, he genernl habits it resembles, is of rare occurence or the hor Long Island. "It breeds in the

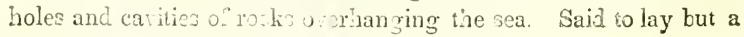
cingle cgg, which is white, and nearly round." 


\section{'THLASSIDROMA PELAGICA-LINN.}

\section{LEAST PETREL.}

Stormy Petrel, Thalossidroma pelagica, Nuttall.

Least Petrel, Thalassicioma pelagica, Audubon.

Specific Character- Bill and feet black, from the frontlet feathers 3-8thsclan inch, tarsi $3-4$ ths; upper parts ra rablack; lower parts soot $y$ brown; recondary coverts tipped with white; the rump and upper tail cacris broadly tipped with white, later later blail slightly rourced; webs wholly black. Len stix inches, wing four and five-eighthe

This, the ar alicat of the Petro', in c'.. el s allied to Wilson's Perel, both in hebic anc flumagc; it diror frem that pecies in being about cne inc arc a half less in length, and also in the absence of the yello pr an the robs, and having the onire lower parts sooty brown. The Least Petrel is said to breet on the Orkneys and $\mathrm{He}$ brides, on the cliffs. The egogs are two. Noi uncommon on the banlis of Newf ndland, and not obserwed to icreed on the American coast.-Auduōon.

\section{GENTS MORION. ILLEGR. DUFFIN.}

[Bill abnut tho length of the head, extremely comnressed, as high as long; head large ; ncck s'lort, thick; body full; wings short; tail short, slightly rounded, of sisteen ferthers; tarsi and feet short-the latter rather strong, and placed far behind the centre of the body.]

\section{MORMON $\triangle$ RCTICUS-LINN.} COMNCN CR ARCTIC PUEFIN.

Normon Areticus, Bonap. Syn.

Putfin, Mormon Arcticus, And. Orn. Biog.

Puffin, or Coultermbe, Nuttall.

Specific Characier-Bill about the length of the head; at the base very high, becoming gradually reducer? to a point; anterior to the nostrils much compressed, with three distinct curved grooves on both mandibles, the ridge of both and basal rim of upper, dull yellow; anterior to the rostrils red; the rest part blue. Adult nnale with the upfer part of the head, hind nec:; and a broad colla passing round 
on the fore neck, and the entire upper parts, black; sides of the head and throat grayish-white; lower parts white; a horny substance on the upper eyelid; feet bright red. Length twelve inches and a half, wing six inches.

The Puffin is said to inhabit the northern regions of both continents, migrating in Winter to the temperate shores of the United States and Europe. In the dreary regions where it dwells, it is said to be very abundant. They associate in large flocks, and pass most of their time on the water, feeding on a variety of small fish, crabs, shrimps, and sea-weed, from which their flesh acquires a rank flavor. It is said it builds in great numbers on the cliffs, digging gcnerally burrows with its bill and claws in the earth, collected in the cavities of the rocks, in which it lays a single egg. It but seldom occurs, and only in winter on the coast of Long Island.

\section{GENUS ALCA-LINN.}

\section{AUK.}

[Bill about the length of the head, broad at the base, higher beyond the nostrils, hooked, and feathered about half its length; head rather long ; neck short, thick; body full; wings short and narrow; tail of twelve or more pointed feathers; feet short, stout, and placed very far behind; webs entire, hind toe wanting.]

\section{ALCA TORDA-LINN.}

\section{RAZOR-BILLED AUK.}

Alca Torda, Bonap.

Razor-bill Auk, Alca Torda, Nuttall.

Razor-bill Auk, Alca Torda, Aud.

Specific Character-Bill black, feathered to the nostrils, anterior to which it is high, compressed, with five grooves; upper mandible much rounded. Adult with the third groove on the upper mandible white; a similar band on the lower mandible; a white line from the ridge of the upper mandible passing back to the eye; lower parts and sides of the neck white; head, hind neck, and upper parts of the body black, tinged with brown; throat, and upper portion of the sides of the neck shaded with purplish-brown; the secon. daries distinctly tipped with white; tail black, the feathers pointed, middle pair longest; feet black. Length seventeen inches and a 
half, wing eight. Young without the white line anterior to the eye, and the white bands on the bill wanting.

This is another of those marine birds which inhabit in general the northern parts of both continents, and only visits the United States during winter. According to Mr. Audubon, it breeds in great numbers on the Gannet Rock in the Gulf of St. Lawrence, on the shores of Newfoundland, and the western coast of Labrador, chiefly in the fissures of rocks. With us it is not common, though occasionally observed along the coast, and sometimes stragglers are seen wandering over the South Bay. During the winter months it is occasionally exposed for sale in the New York market, although it is of no value for the table, on account of its flesh partaking strongly of the flavor of its food. Still, like all other species that are rare with us, it is always in request by amateurs.

\section{GENUS MERGULUS-RAY.}

SEA-DOVE.

[Bill shorter than the head, stout, tapering, compressed toward the end; tip of upper mandible declinate, feathered to the nostrils ; lower mandible feathered beneath, nearly the entire length ; head large ; eyes small ; neck short, full ; body compact ; wings narrow, pointed, of moderate length ; tail very short, rounded; tarsi short ; feet short ; toes connected by entire webs, hind toe wanting.]

\section{MERGULUS ALLE-LINN.}

COMMON SEA-DOVE.

Alca Alle, Wilson.

Uria Alle, Bonap.

Little Guillemot, Uria Alle, Sw. \& Rich.

Little Auk or Sea Dove, Nuttall.

Little Guillemot, Uria Alle, Aud.

Specific Character-Bill black, short, stout, feathered to the nostrils, as also to near the end of lower mandible, tarsi 11-16ths of an inch ; tail short, rounded; feet pale flesh color; neck rather short; body plump. Adult in spring with the head and neck all round, with the upper parts black; lower parts white; scapulars margined with white, seconddries tipped with the same. Winter plumage, throat, fore part and sides of the neck, with a band on the hind neck, and 
the lower parts white; scapulars and secondaries same as in spring. Length eight inches, wing four and a half.

The "Sea" or "Greenland Dove," I am informed is occasionally seen by the fishermen at Egg Harbor, when they are hanling their nets outside of the beach. It is a good diver, flies well, and subsists on small fish; not being very timid, it jo easily secured. The collection of Mr. Lawrence contairs a sperimen that was killed at Raynor South. In the United States it is rare. It is often met with far at sea, and is said to breed on the Arctic coast.

"In Greenland and Sritzbrgen the ongrenate in larne flocks; and in the depth of winter, watching we motion of the ice in the cfing, when it is broken wi, by storns, the crowd by thousands into every fissure or faw, in ord or wa met p the marine producEions on which they subsist." Wr. Aidubea found a "cry breeding on the coast of Labrador. Ther are also me with a: "'ewfoundland, where is is called 'Ice Eird.' "Captain Rous's party met with these birds in great numbers on the : con co Greenland, where they wero slizt daily, and supplied to he hig's company, who found them very palatalle, and free from any fichy taste, though their foo encists chiefly of a small pocie. ?rab (cancer) with which lis Aiclis scai abound."

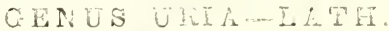

Luintivior.

[Bill slorter than the iead, strong and tapering, huzd inge; neck short

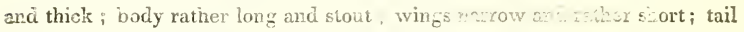
very short and roundea: leet short, ani placed far hehini. ]

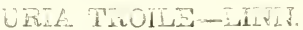

\section{FOOLISH GUIILEMOT.}

Uria Troile, Bonsp

Uria Troile, Fooinsi Gnillemot, Sw \& Rich.

Foolish Guillemot, or Mure, Nuttall.

Foolish Guilemot, Uria Troile, Aud.

Specific Character-Eill black, much compressed toward the end, irom the corner of the mouth to the point wwo inches and \& quarter; 
upper mandible decurved, distinctly notched; length of tarsi one inch and an eighth. Adult in summer with the head, upper portion of the neck in front, hind neck, and all the upper parts blackish brown; ends of the secondaries, outer primaries toward their bases, and a ring round the eye, white. In winter, the throat, upper part of the sides of the neck, and the entire fore neck, white. Length eighteen inches, wing eight.

During winter this species is occasionally met with along the shores of Long Island. According to Mr. Audubon, it breeds on the rocky islands of the Gulf of St. Lawrence, Newfoundland, and Labrador. The eggs, eight of which $\mathrm{I}$ have before me, are large for the size of the bird, and differ materially in color, and somewhat in form. They are all more or less blotched with brownish-black ; the ground color in some is dark green, in others pale blue and yellowish-brown, and in one specimen in my possession, white, with the dark-colored markings confined almost exclusively to the great end. It is said to inhabit the Arctic seas of both continents, passes most of its time at sea, and feeds on fish, which it procures by diving. During the breeding season it suffers itself to be seized by the hand, or killed on the spot, rather than desert its favorite cliff-hence the name "Foolish Guillemot."

The Large-billed Guillemot, [Uria Brunnichii] I have never seen. From the description given, it can be distinguished from the first species, by having the upper mandible three times as long as broad ; [the upper mandible of $\mathrm{U}$. troile is more than four times as long as broad] and one inch greater in length. In the description given of its plumage, we notice that it differs only from $U$. troile by wanting the white ring round the eye. 'The dimensions from tip to tip of expanded wings, is said to be thirty inches in both species.

\section{URIA GRYLLE-LINN.}

\section{BLACK GUILLEMOT.}

Uria Grylle, Bonapart.

Uria Grylle, Black Guillemot, Nuttall.

Black Guillemot, Uria Grylle, Audubon.

Specific Character-Bill black, rather slender, from the corner of the mouth to the point one inch and five eighths; length of tarsi 
one inch; tail short, rounded. Adult male with the head and neck all round grayish-white, mottled with dusky; darker on the crown; upper parts black; the feathers tipped with grayish-white, of which color is the rump; tail brownish-black; wings of the same color, their coverts white, forming a conspicuous patch on the wings; lower parts white; feet vermilion. In summer, general color of plumage black; upper parts tinged with green-the lower with brown; the white patch on the wings same as in winter. Length thirteen inches and a half, wing six and a quarter.

The Black Guillemot is said to inhabit the Arctic seas of both continents. Like the rest of this tribe, it lives almost entirely on the water, and seldom resorts to the land, except for the purpose of incubation, which Dr. Richardson informs us, is performed in the holes of rocks, from whence it can easily throw itself into the water. It abounds in the Arctic seas and straits, from Melville Island down to Hudson's Bay, and remains, though in diminished numbers, all the Winter in the pools of open water which occur ever in high latitudes, among the floes of ice.-Fauna Boreali Americana, page 478.

\section{GENUS COLYMBUS-LINN.}

DIVERS.

[Bill longer than the head, straight compressed; stout, narrowed toward the point; head rather large, oblong, narrowed before-the feathers advancing on the sides of the upper mandible as far as the nostrils; neck rather long and thick; body long, heavy, and depressed; wings small, narrow ; quills stiff; tail very short, rounded; feet large, placed very far behind; tarsi compressed.]

\section{COLYMBUS GLACIALIS-LINN.}

\section{GREAT NORTHERN DIVER.}

Great Northern Diver, or Loon, Wilson.

Colymbus glacialis, Bonapart.

Colymbus glacialis, Great Northern Diver, Sw. \& Rich.

Loon, or Great Northern Diver, Nuttall.

Great Northern Diver, or Loou, Colymbus glacialis, Audubon.

Specific Character-Bill black, very strong, from the corner of the mouth to the point four inches and a half; length of tarsi three inches and three-eighths. Adult with the bill black; head and neck dark green, with blue and purple reflections, and longitudinal 
white markings on the lower part of the throat and on the sides of the neck, the feathers forming this character are raised, giving it a ribbed appearance; lower parts white, with a band of dusky crossing the vent; under tail-coverts brownish-black, spotted with white near the ends; tail-coverts brownish-black, spotted with white near the ends; tail brownish-black; upper tail-coverts black, spotted with white; upper parts and sides of the body black, spotted with white-the spots on the scapulars much larger. Length thirty-one inches, wing fourteen and a quarter. Young, upper parts brown, the feathers margined with lighter; sides dark brown, without spots; sides of the neck streaked with dusky; lower parts white.

The Great Northern Diver or Loon, as it is termed by the gunners, seldom associates in flocks. During the Winter, singly or in small parties, they are dispersed throughout the Union.' This cautious bird, as if knowing man to be its mortal enemy, is constantly on the watch. When meeting a passing boat, it widens the distance by immediately steering off-is active in diving-and when sitting, defies the keenest sportsman. 'The Loon is a hardy bird, and it is said lives to an incredible old age. A short time since a specimen was killed on the eastern end of Long Island, in which was found the head of an Indian pile, confined in the back of the neck, between the bone and the skin. The wound was completely healed, and had the appearance of having been made a long time. This led to many conjectures. Some supposed that it received this wound before the settlement of the country. Others were of the opinion-which I think more probable-that during its wanderings it had visited the far West, where the bow sends the messenger of death. This species utters a melancholy moan, which, when often repeated, is said to forebode a storm. Its flesh is of no value, being tough and rank. Its skin is sometimes worn by sailors, as well as by the "Greenlanders," in the place of caps. The difference in the plumage between the adult and young bird is so strongly marked, that I have occasionally had the former brought to me by the gunners, they supposing it to be a rare bird. I am inclined to think it does not appear in perfect plumage until 
the third year. Doctor De Kay found this species breeding in the Racket Lake. It makes its nest of a coarse material, in which it deposits two eggs, of a dark brown color, blotched with black.

It subsists chiefly on fish-is an excellent diver-and when alarmed, eludes pursuit by passing swiftly to a considerable distance under the water. The habits of the Northern Diver are strictly aquatic. I have never observed it on shore, and from the position of its legs, which are placed so very far behind the centre of the body, if it can walk at all, its progression must be with an exceed. ingly awkward gait. In its appropriate element, it is not surpassed by any of its tribe. Its flight is rapid, and at times, when passing over the land, is performed at a great height. In stormy weather, it sometimes takes shelter in the coves and creeks, and occasional. ly roosts on the mill ponds.

\section{COLYMBUS SEPTENTRIONALIS-LINN.}

\section{RED-THROATED DIVER.}

Colymbus septentrionalis, Bonapart.

Red-throated, Diver, Colymbus septentrionalis, Sw. \& Rich.

Red-throated Diver, Nuttall.

Red-throated Diver, Colymbus septentrionalis, Audubon.

Specific Character-Bill black, slender, pcint acute, from the corner of the mouth to the end three inches; length of tarsi two inches and three eighths; neck rather slender; forehead low. Adult with the bill black; throat, sides of the head and neck mouse-color; a broad band of reddish-brown commencing at the lower part of the throat, extending about three inches on the fore neck; lower parts white, with a band of dusky crossing the vent ; under tail-coverts dusky, tipped with white; tail and upper tailcoverts same color; upper parts dark brown, spotted with whitethe spots more numerous and larger on the sides of the body and fore part of the back; nape streaked with white and greenish black; crown spotted with dusky. Length twenty-three inches and a half, wing eleven inches. Young, in winter, with the fore part of the neck white, or slightly mottled with red.

This species is another of those hardy sea-birds like the preced. ing whose habits it resembles; is common to both continents, and 
is said " to attend the arrival of the sprats on the river Thames, and is there called by the fishermen "Sprat Loon." Mr. Audubon found it and the preceding species breeding at Labrador.

Those procured in this vicinity are usually young birds-adults seldom occurring. "The Red-throated Diver frequents the shores of Hudson's Bay, up to the extremity of Melville Peninsula, and it is also abundant on the interior lakes. It lays two eggs, on a little down, by the margin of the water, which have a pale oil-green color."-Fauna Boreali Americana, part second, page 479.

\section{GENUS PODICEPS-LATHAM.}

GREBES.

[Bill about the length of the head, straight, compressed, hard-pointed, flattened at the base; head rather small, oblong, narrowed before; eyes near the bill; neck slender and rather long; body much depressed; wings short, narrow; tail a tuft of short feathers ; feet large, placed very far behind ; toes four ; hind toe small-outer toe the longest; anterior toes connected at the base by a membrane, and furnished towards the end on both sides with a broad lobe, much broader on the inner side-that of the middle the broadest; tsrsi extremely compressed.]

\section{PRODICEPS CORNUTUS-LINN.}

\section{HORNED GREBE.}

Podiceps cornutus, Bonap.

Podiceps cornutus, Horned Grebe, Prodiceps cornutus, Sw. \& Rich.

Horned Grebe, or Dobchick, Nuttall.

Horned Grebe, Podiceps cornutus, Audubon.

Specific Character-Bill black, the point yellow, from the corner of the mouth to the end one inch and a quarter, length of tarsi one and five-eighths. Adult male with the bill black; a brown band faom the bill to the eyes, which are red; sides of the head tufted, with a yellowish-brown band behind the eyes; nape and upper parts blackish-brown; throat black; fore part, sides of the neck and sides of the body, reddish-brown; lower parts glossy white; vent brownish-gray; primaries brown; a few of the secondaries white, with a spot of brown toward their ends. Length fourteen inches and a a half, wing five-eighths. Young, without the tufts on the sides of 
the head; upper part of the head, nape, and upper parts dusky; throat, and a large patch on the sides of the head, nearly meeting behind, white; fore-neck grayish-white; lower parts glossy-white; vent grayish; bill and feet bluish, the former with a white spot at the tip.

This bird I have met with in various districts, from New-Orleans to Green Bay, and it is said that "during summer it is abundant in the Fur Countries, frequenting every stream with grassy borders." With us it is quite common, and it is well known to the gunners by the name of "Hell Diver," so called from its activity in diving. It inhabits usually the submerged meadows, and when surprised, avoids pursuit by diving. In the month of June it commences preparing its nest, which is constructed of coarse materials, and attached to the rank grass and weeds. The eggs, which are from three to four in number, are white, spotted with dull brown. Its food is chiefly fish, which imparts to its flesh an unpalatable flavor. The North-western Indians, in whose district of country it is said to abound, convert the soft and silken plumage of the breast into garments.

\section{PODICEPS CAROLINENSIS-LATHAM.}

\section{PIED-BILL DOBCHICK, OR GREBE.}

Podiceps carolinensis, Bonap. Syn.

Podiceps carolinensis, Pied-bill Grebe, Sw. \& Rich.

Pied-bill Dobchick, Podiceps carolinensis, Nuttall.

Pied-bill Dobchick, Podiceps carolinensis, Aud. Orn. Biog.

Specific Character-Bill pale blue, the ridge of the upper mandible dusky; a black band on the lower anterior to the nostrils along the gap one inch and a half, tarsi one and a half. Adult male with the upper part of the head, nape, back and wings blackish-brown, with a few touches of reddish-brown on the former; cheeks grayishwhite; a patch of black on the throat; fore neck and sides of the neck reddish-brown; upper portion of the neck lighter; breast and abdomen silver white; sides of the body dusky, intermixed with reddishbrown; vent dusky. Female without the black band on the bill, or the black patch on the throat. Length fourteen inches, wing five and a half. 
This species is common along the Atlantic Districts, as well as in the interior; it is generally found on fresh water streams. Like the former species, it passes most of its time on the water, and seldom resorts to land except for the purpose of reproduction. Breeds in various parts of the Union. At the approach of winter migrates South.

\section{PODICEPS CRISTATUS-LATHAM.}

CRESTED GREBE.

Podiceps cristatus, Bonap. Syn.

Podiceps cristatus, Crested Grebe, Sw. \& Rich.

Crested Grebe, or Gaunt, Guttall.

Cristed Grebe, Podiceps crestatus, And. Orn. Biog.

Specific Character-Bill along the gap two inches and five-eighths, length of tarsi two and three-eighths. Adult male with the bill blackish-brown; upper part of head and the crest black; cheeks, throat, and band before the eye white; ruff reddish-brown, terminating with black; nape and upper parts blackish-brown; shoulders of the wings and the secondaries white; flanks and the sides of the upper portion of the breast, reddish-brown; the rest part of the breast, fore neck, and abdomen white; eyes light red; bill blackish-brown, feet greenish-black. Female, with the crest very slight; sides of the body dusky, upper parts tinged with gray; bill duskygreen. Length twenty-four inches, wing seven and a half.

The Crested Grebe is said to inhabit the North of both continents, from which it migrates on the approach of winter to a more moderate climate. In the middle districts it is not of frequent occurrence, but more common on the large streams in the interior. It is occa. sionally observed about the submerged meadows on Long Island. Like the rest of this tribe, it is exclusively aquatic, and feeds chiefly on small fish, which it procures by diving. Early in Spring, it moves on to the North, where it passes the season of re-production. "The Grebes are to be found in all the secluded lakes of the mountainous and woody districts of the Fur Countries Its nest, formed of a large quantity of grass, placed among reeds and carices, rises and falls with the water. It feeds on small shell-fish, frogs, and insects."-Faura Boreali Americana. 


\section{PODICEPS RUBICOLLIS-LATHAM.}

\section{RED-NECKED GREBE.}

Podiceps rubricollis, Bonap. Syn.

Podiceps rubricollis.

Red-necked Grebe, Sw. \& Rich.

Red-necked Grebe, Nuttall.

Red-necked Grebe, Podiceps rubricollis, Aud. Orn. Biog.

Specific Character-Bill black, toward the point white, from the frontlet feathers to the end, two inches and one-sixteenth, length of tarsi, two and a half.

Adult male with the bill at the base yellow-at the end black; a white line from the bill to the eye; hind part of the head tufted; upper part of the head black; cheeks and throat grayish-white; fore part and sides of the neck brownish-red; lower parts silvery white; upper parts dusky; outer secondaries white; tarsi and toes greenish-black on the outer sides-inner sides yellow. Young, in winter, with the bill yellow-its ridge dusky; upper parts blackishgray; lower parts grayish-white.

This, like the former species, dwells amid the dreary regions of the North, and only visits the United States during winter. It is generally observed along the sea-coast, and occasionally extends its migrations as far as Long Island. Those procured in this vicinity are nearly all young birds-the adult being a great rarity. 


\section{IP 25}

The Names of Synonymous Genera and Species are in Italics.

Accipiter palumbarius

"Pennsyluanica

Agelaius phœniceus

Alxuda

6: alpestris

" cornuta

6. magna

") rufa

Alca

" alle

"Torda

Alcedo

" alcyon

Ammodramus

". caudacutus

6. maritimus

" palustris

Ampelis Americana

"S Sialis

Anas

6: acuta

"albenla

"A Americana

": Bernicla

" boschas

"Canadensis

"Carolinensis

" caudacula

" clangula

" clypeata

"srecca

"discors

"domestica

" ferina

"Fuligula

"fusca

" glacialis

" Ristrionica

" liyperboreus

"Labradora

" niarila
18 . I nas mollissima

19 " nigra

141 " obscura

95 "Penelope

95 " perspicillata

95 " rubila

147

94

374

375

374 Anser

172 6: albifrons

172 "Bernicla

112 "Canadensis

113 " hyperboreus

112 Anthus

114

163 Aquila

81 ": chrysætos

299 " leucocephalo

310 Ardea

335 " alba

306 " candidissima

293 " corulea

299 " Egretta

289 ": exilis

314 " Herodias

310 " lentiginosa

334 "Ludoviciana

314 " minor

314 " nycticorax

315 "violacea

299 " virescens

320 Astur

324 " Cooperii

328 " fuscus

337 " palumbarius

336 Bombycilla

297

"

Carolinensis

327

"

321 Bubo
331

330

301

307

329

326

324

312

304

318

289

296

293

289

297

94

94

8

8

9

276

288

283

382

288

287

276

285

281

285

279

280

284

18

20

19

18

163

163

164

27 
Bubo asio

"Virginianus

Buteo

"borealis

"cyaneus?

"6 lagopus

"6 lineatus

"Pennsylvanicus

Caladris

" arenaria

Caprimulgus

$\begin{array}{ll}\text { " } & \text { Americanus } \\ \text { " } & \text { Virginianus } \\ & \text { vociferus }\end{array}$

Carduelis

" tristis

Cathartes

" aura

Certhia

"Caroliniana

". familiaris

"varia

Chætura

Charadrius

$$
\text { " pelasgia }
$$

$\begin{array}{ll}\text { " } & \text { Caladris } \\ " & \text { helveticus } \\ " & \text { Hiaticula } \\ " & \text { marmoratus } \\ " & \text { pluvialis } \\ " & \text { semipalmatus } \\ " & \text { vociferus } \\ " & \text { Wilsonius }\end{array}$

Chordelies

Circus

$$
\text { " Virginianus }
$$

$$
\text { " cyancus }
$$

Clangula albeola

$$
\text { " } \quad \text { histrionica }
$$

Coccoborus

$$
\text { "Ludovicianus }
$$

Coccyzus

Americanus

" Doninicus

" erythrophthalmus
$28 \mid$ Colaptes auratus

27 Columba Carolinensis

181

3 " migratorius

3 Colymbus

21 " glacialis

6 " 6 septentrionalis

7 Corvus

\begin{tabular}{r|ll}
5 & " Americanus & 151 \\
243 & " corax & 149
\end{tabular}

243 " corone

151

31 " cristatus

153

32 Corythus

32 " enucleator

31 Cuculus Carolinensis

128

1.8

182

117 " erythrophthalmus 183

117 Culicivora

1 " cœrulea

1 Curvirostra Americana

46

46

130

71 Cygnus

75 " Americanus

71 Cypselus pelasgia

70 Dendronessa sponsa

33 Dolichonyx

33 " orizivora

298

298

33

312

137

211 Ectopistes

243 " Carolinensis

137

184

211

6

migratorius

186

217 Emberiza

213 "

Americana

184

100

217 " Canadensis 107

213 " erythrophthalma

215 " graninea

218 " Henslowii

216

32

32

21

21

335

336

334

133 Erythaca Wilsonii

124

101

104

99

97

137

103

139

105

102

106

133 Erythrospiza

81

126

182 "

182 Falco

14

183 " atricapillus

18 
Falco chrysaetos

" columbarius

"Cooperii

" cyaneus

"fulvus

"furcatus

"fuscus

" haliaetus

" hyemalis

" lagopus

" leucocephalus

«lineatus

" niger"

" ossifragals

" palumbarius

"Pennsylinanicus

" peregrinus

" sparverius

"Stanleii

" aliginosus

"velox

Fringilla

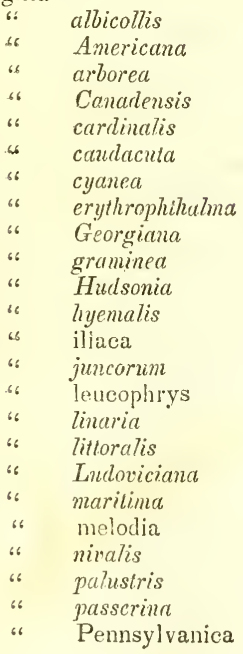

8'Fringilla pinus

17 " purpurea

20 " pusilla

21 " rufa

8 " savanna

13 " socialis

19 " 1 tristis

9, 11 Fulica

7 "Americana

6 "atra

9 Fuligula

7 " " albeola

6 " Americana

- 9 " Clangula

18 " ferina

5 " fusca

14 " glacialis

16 ". histrionica

20 " Labradora

21 " marila

19 " marila

119

122

100

107

107

132

113

110

124 Gallinula

114 " chloropus

101 " galeata

108

" Martinica

108 " Porphyrio

119 Gracula ferruginca

105 " quiscala

123 Garrulus

116 " cristatus

113 Hæmatopus

133 " Ostralegus

112 " palliatus

121 Haliætus

108 " leucocephalus

114 Harelda glaciatis

103 Helinaia

122 " chrysoptera
115

126

105

119

102

106

117

200

200

200

318

335

330

334

320

328

337

336

327

321

323

323

331

330

329

326

324

333

318

197

197

197

198

198

146

145

153

153

222

222

222 
Helinaia rubricapilla

$$
\text { " Solitaria }
$$

Himantopus

Hirundo

nigricollis

$\begin{array}{ll}\text { " } & \text { Anericana } \\ \text { " } & \text { bicolor } \\ \text { " } & \text { pelas } \\ \text { " } & \text { purpura } \\ \text { " Jiparia } \\ " & \text { rufa } \\ \text { " } & \text { rustica } \\ \text { " } & \text { viridis }\end{array}$

Ibis

" alba

Icteria

$$
\text { "viridis }
$$

Icterus

$$
\begin{aligned}
& \text { " agripennis } \\
& \text { " Baltimorc } \\
& \text { " pecoris } \\
& \text { " phænicsus } \\
& \text { spurius }
\end{aligned}
$$

Lanius

": borealis

" cxcubilor

" seplentrionatis

Larus

" argentatus

" atricilla

"Bonapartii

" canus

" capistratus

" glaucus

" marinus

" rudibundus

"Sabini

" triclactylus

" zonorhynchus

Lestris

"Buffonii

" parasiticus

" pomarinus

6: Richardsonii

Limosa
6? Limosa Fedoa

66 " Hudsonica

259

67. Linaria

360

270 " minor 116

270 " pinus 115

34 Lobipes

35 " heperborcus

246

36 " TVilsonii

38 Lilsonit

33 " cardinatis 132

34 " curvirostra 330

37 " cmucleator $\mathbf{3 2 8}$

35 " leucoptera 131

35 " rosea ]::3

36 Mclainerpes erythrocephatus 180

275 Mergulus 375

275 6 Alle 375

162 Mergus $\quad 3: 39$

162 "cucullatus 141

142 "Merganscr 33!)

137 " serrator 342

142 Merula migratoria $\quad \varepsilon 6$

139 " minor 89

141 " solitaria 90

144 Microptera 266

155 " Americana 266

155 Mniotilta

155 " varia 70

155 Molothrus 139

357 " pecoris 139

357 Mormon 373

3i) " arcticus 373

359 Mucicapa 39

360 " acallica $\quad \angle 0$

359 " "Canadensis 49

363 " "canlatrix 158

361 " corvulea 46

358 " crinita 41

362 " cucrullata 47

361 " " fusca 42

360 " " melodia 161

364 "

364 "6 olivacea 157

364 " " pusilla 44

366 " " pusilla 51

367 " "querula $\$ 0$

259 " rapax 43

" ruticilla 45 
Musci`apa solitaria

$$
\begin{array}{ll}
\text { “ sylvicola } \\
\text { "Tyrannus } \\
\text { " virens } \\
\text { "Wilsonii }
\end{array}
$$

Myiodioctes

$\begin{array}{ll}\text { " Canadersis } \\ \text { " } & \text { Witratus } \\ & \text { Wilsonii }\end{array}$

Nauclerus

" furcatus

Niphaea

" hyemalis

Numenius

" borealis

" Hudsonicus

" longirostris

Oidemia Americana

$$
\text { "fusca }
$$

" perspicillata

Oriolus Bultimore

" mutatus

Orpheus

" Carolinensis

"fitivox

" polyglottus

" rufus

Ortygometra

Carolinus

Noveboracen

“

Ortyx

"Virginiana

Otus

"brachyotos

"vulgaris

Pandion

“ haliaetus

Parus

$$
\text { ‘: atricapillus }
$$

" bicolor.

Phaiacrocorax

$$
\begin{aligned}
& \text { " Carbo } \\
& \text { " dilophus }
\end{aligned}
$$

Phalaropus

$$
\text { " fulicarius }
$$

160|Phalaropus lobatus

159

Wilsonii

39 Perdix Virgininna

43 Picus

51 " auratus

4ī “ Canadensis

49 " Carolinus

47 " erythrocephalus

51 " pubescens

13 " septentrionalis

13 " varius

105 " villosus

108 " villosus

271 Pipilo

$2 i 4$ " erythrophthalmus

272 Pipra polyg otta

271 Pitylus

330 " cardiualis

328 Plectrophanes

329 " " Lapponica

142 " nivalis

144 Podiceps

82 " Carolinensis

S4 " cornutus

S4 " cristatus

82 " rubricollis

Sj Procellaria pelagasia 201 Puffinus

201 " anglorum

cinereus

187 " obscurum

15? Pyranga

25 " rubra

26 Pyrrtiula enucleator

25 Quiscalus

11 " ferrugineus

11 " versicolor

77 Rallus

77 "Carotinus

78 " crepitan

343 " elegans

343 “ Noichoracensis

314 “ Virginianus

245 Recuri irostra
132

97

99

97

381

382

381

383

384

370

368

369

368

370

135

135

128

145

146

145

204

201

206

209

204

$20 \mathrm{~s}$

269

269

270 
Regulus

$$
\begin{array}{ll}
\text { " calendula } \\
\text { " } & \text { cristatus } \\
\text { " } & \text { satrapa } \\
\text { tricolor }
\end{array}
$$

Rhynchops

$$
\text { “ nigra }
$$

Saxicola Sialis

Soolccophagus forrugincus Scolopax

$\begin{array}{ll}\text { " } & \text { borcalis } \\ \text { " Fedoa } \\ \text { " flavipes } \\ \text { " gallinago } \\ \text { " } \text { minca } \\ \text { " Noveboracensis } \\ \text { " scmipalmatus } \\ \text { " voriferus } \\ \text { Wilsonii }\end{array}$

Seiurus

" aurocapillus

"Noveboracensis

Sialia

$$
\text { "Wilsonii }
$$

Sitta

"Canadensis

"Carolinensis

Somateria Mollissima

Spiza

$$
\text { spectablis }
$$

Sterna

$$
\text { cyanea }
$$

$$
\begin{array}{ll}
\text { “ } & \text { Anglica } \\
\text { “ } & \text { aranca } \\
\text { argentea } \\
\text { “ } & \text { Cayana } \\
\text { " } & \text { Dougalli } \\
\text { “ } & \text { Hirundo } \\
\text { " minuta } \\
\text { " nigra } \\
\text { "Tudeauii }
\end{array}
$$

Strepsilas.

Strix acadica

$$
\text { "Asio }
$$

79|Strix brachyotos

79 " navia

So " nebulosa

S0 " nyctea

80 " Otus

346 " passerina

346 "Virginiana

81 Sturnella

146 " Ludoviciana

261 Sturnus Ludovicianus

27\% " prodatorius

259 Sula

250 "Bassana

261 Surnia

263 " nyctea

266 Sylvia ostiva

263 " Americana

254

252

261

92

9

93

S1

81

166

16

166

331

333

110

110

347

353

353

350

355

351

347

350

352

354

220

220

28 
Sylvia striata

$$
\begin{aligned}
& \text { "Troglodytes } \\
& \text { " varia } \\
& \text { "vernivora } \\
& \text { " virens } \\
& \text { "Wilsonii }
\end{aligned}
$$

Sylvicola

$\begin{array}{ll}\text { " } & \text { aestiva } \\ \text { “ } & \text { Americana } \\ \text { " } & \text { Canadensirniae } \\ \text { “ } & \text { castanea } \\ \text { " } & \text { coronata } \\ \text { " } & \text { discolor } \\ \text { " } & \text { icterocephala } \\ \text { " } & \text { maculosa } \\ \text { " } & \text { maritima } \\ \text { " } & \text { petechia } \\ \text { " pinus } \\ \text { " striata } \\ \text { virens }\end{array}$

Syrnium

" nebulosa
Tanagra rubra
Tantalus albus
" cupido
" umbellus

Thalassidroma

$\begin{array}{ll}6 & \text { Leachii } \\ \text { " } & \text { pelagica } \\ \text { Wilsonii }\end{array}$

Totanus

$\begin{array}{ll}\text { " } & \text { Bartramius } \\ \text { " } & \text { chloropygius } \\ \text { " flavipes } & \text { macularius } \\ \text { " } & \text { melanoleucus } \\ \text { " semipalmatus } \\ \text { " } & \text { solitarius } \\ \text { vociferus }\end{array}$

Trichas

" Marylandica.

Tringa

“ Philadelphia

" alpina
53 $\mid$ Tringa arenaria 243

72 "Bartramia 226

70 " cinerea 224

67. " Tiaticula 215

57 " himantopus 232

57 " interpres 220

51 " Islandica 224

58 " macularia 257

60 " maritima 236

53 " pectoralis 233

56 " " pusilla 240

62 "rufa 224

55 " rufescens 230

52 "Schinzii 241

63 " semipalmata 239

54 " solitaria 256

61 " subarquata 237

59 "Wilsonii 240

51 Trochilus $\quad 169$

53 “ colubris 169

57 Troglodytes 72

24 " aedon 73

24 " " Americanus 74

135 “ " Europacus 72

275 " “ hyemalis 72

191 “ “ “udovicianus 75

195 “ palustris 76

191 Turdus $\quad 86$

370 " aquaticus 93

372 " aurocapillus 92

373 " felivox 84

370 " "lividus $\$ 4$

250 "Ludovicianus 93

226 " melodius 58

256 " migratorius 86

250 " minor 90

257 " mustelinus SS

252 " mustetinus 89

254 " Novcboracensis 93

256 " oliveceus 91

252 " polyglottus - 82

64 "rufus $\$ 5$

64 "solztarius 90

65 "Wilsonii " 89

224 Tyranula pusilla 44

228:Ulula 23 
( 392 )

Ulula acadica

23|Vireo

157

Uria

"A77e

376 "flavifrons

159

375 " gilvus 161

" Grylle

377 "Noveboracensis

161

"Troile

376 " olivaceus

15

Vancllus melanogaster

211 " solitarius

] 57

160 


\section{INDEX OF ENGLISH NAMES.}

Auk, Razor-billed

Avocer, American

Beach-bird

Bit ern, Amcrican " Jeast

Black-Bird Crow

Blue-Bird

" Red-ivinged

blue-Stucking

Boh-c-Link

Brant

Brant-Bird

Brown Thrasher

Bunting, Bay-winged

"Black-throated

- Carada

" Chipping

" Ficld

"Henslow's

"Indigo Painted

"Sarannah

"S Silow

"Towhe

"Yellow-winged

Butcher-Bird

Butter-bill

Butter-liox

Buzzard, Broad-winged " Red-tallod

" Rough-legged

Cat-Bird

Cedar-Bird

Chat, Yellow-breasted

Chalk-line

Cherry-Bird

Chewiuh

Chicarlee

Chipping-Bird

Clape

Coot, American

Coot

Cormorant, Common

Cow-pen-Bird "6 Double-crested

Craste, Blue

Creeper, Black and white

"Brown Tree

Crossbill. Common

"Whito-winged

B
A

220, 217, 243 Cucliou, Black-billed

$$
\text { 28.5 "Yclio'v-billed }
$$

287Curlew, Cape

I45 " Esquimaux

141 " Hudsonian

137 " Jack

81 " lang-billed

269 " Short-billed

137 "Sickle-bill

293

220 Dipper

85 Diver. Great Northern

101 " Red-throated

109 Doc-bird

167 Dove, Carolina Long-tailed

106 "Gicenland

105 " Sea

104 " T'urt!e

110 "Wandering long-tailed

102 Dowitcher

97 Duck, Bald-pate

124 " Black

103 "Blacli-lıcaded

155 " Broad-bill

330 " Broad bill, Creck

33.5 " Broad-bill, Lesser

5 "Buffel-headed.

3 "Butfalo headerl

6 " "Butter-bill

"Butter-ball

"Butter-box

163 " Canvass-back

162 "Coot

284 " Coot, white-winged

16:3 "Disky

124 " Eider

77 " English

105,106 " Gadivall

181 " German

200 "Golden-cye

182,183

200

183

182

237

s74

272

272

$2 \pi 1$

272

271

335

378

380

274

I86

375

375

186

184

263

305

301

321

321

323

323

335

335

330

335

335

318

3.30

328

$30 \mathrm{I}$

331

299

304

304

334

328, 329, 3311 " Gray

343 " Great-headed

304,310

334

336

333

327

$\begin{array}{ll}130 \text { " } " \text { Mallard } & 299 \\ 131 & \text { Old Squaw }\end{array}$ 


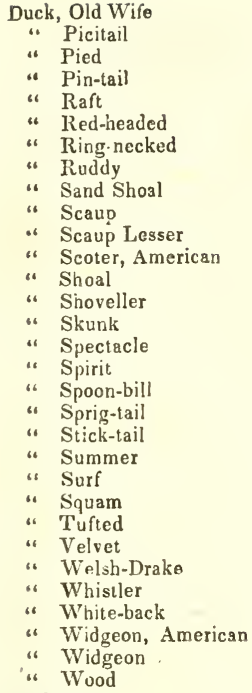

Dunkadoo

Dunlin

$$
\begin{aligned}
& \text { Eagle, Bald } \\
& \text { “ Golden } \\
& \text { “ Gray } \\
& \text { “ Whitc-headed }
\end{aligned}
$$

Egrct, Great American White

Fat Bird

$$
\mathrm{F}
$$

Finch, Crested Purple
" Buff-breasted, Shore
"Fox-colored
" Gold
"Grass
" Gray, Shore
“ Marsh, Shore
"Pine
“Pine common
"Song
"Towhe
“ White-crowned
"White-throated

Fire-Bird
337 Fly catcher, Bluc-gray $\quad 46$

310 " Canadian 49

327 " Great crested 41

310 " G Green black capped 51

321 “ Hooded 47

320 "

324 " Pewce Wood 43

326 " " Pewee Least 44

327 " Red-cyed 157

321 " Redstart American 45

323 "

330 " Solitary 160

331 " "Tyrant 39

317 " Warbling 161

327 " White eyed 158

329 " Yellow-throated 159

335 Flicker $\quad 181$

317 Fiood Gull

310 Fly up the Creek 284

326 Frost Bird . 213

312 Fute $\quad 274$

$\begin{array}{ll}329 & \text { G } \\ 331 & \text { Gallinule, Common }\end{array}$

224 " Purple 198

328 Gallinule, (Crake) Carolina 201

304 " Yellow-breasted 204

334 Gannet, Common $\quad 345$

318 Gnat-catcher, Blue-gray $\quad 46$

306 Godwit Great Marbled $\quad 259$

307 " Hudsonian 260

312 "Teil-tale 252

285 Goose, Brent 293

228 " Canada 289

" Coinmon Wild 289

9 “ Hutchin's 292

8 " Mud 292

9 " Show 297

9 “" Soland 345

288 " White-fronted 296

Goosander 339

233 Goldfinch, American $\quad 117$

126 Grakle, Purple 145

113 " Rusty 146

119 Grebe, Crested 383

117 " Horned 381

101 " Pied-bill 382

112 " Red-necked 384

114 Greenlet, Red-eyed $\quad 157$

115 " Solitary 160

128 " Warbling 161

121 “ White-eyed 158

124 “ Yellow-throated 159

123 Grosbeak, Cardinal 132

122 " 128

135 " Rose-breasted 133 


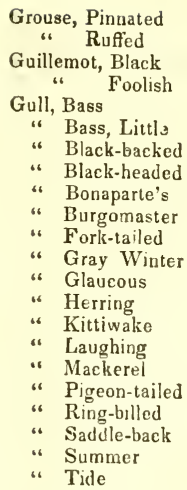

Hawk, Black

“ Booted

“ Broad-winged

“ Bullet

“ Cooper's

“ Duck

" Fish

" Fork-tailed

" Gos

" Great-footed

" Hen

" Marsh

" Pigeon

" Red-shouldered

" Red-lailed

“ Rough-legged

"Sharp-shimned

“ Sparrow

“ Swallow-tailed

Hangnest, Baltimore

Hairy-head Orchard

Harrier, Common

Heath-Hen

Hell-Diver

Heron, Black-crowned

$\begin{array}{ll}\text { " } & \text { Blne } \\ " 6 & \text { Great blue } \\ \text { " } & \text { Louisiana } \\ \text { " } & \text { Snowy } \\ & \text { Yellow-crowned }\end{array}$

Highhold Yellow-crowned

Humming-bird, Ruby-throated
195

191 /bis, White

I

377 Ice-bird

275

376 Indian-Hen

357

359 Jay, Blue

285

361 Jager, Artic

153

364

358 " Pomarine 366

359 "Richardson's 367

363 K

362 King-bird

357 King fisher, Belted 172

363 Kinglet, American Golden crested $\mathbf{8 0}$

$35 \%$ " Ruby-crowned 79

361 L Lapland Long-spir 99

347 Lark, Brown 94

364 " Shore 95

360 " Meadow 147

361 Lark Bunting, Lapland $\quad 99$

347 " Snow 97

347 Lawyer

Linnet, Lesser Red-poll

269,270

6 " Pine

116

115

6 Lobefoot, Hyperborean 248

5. "“ Wilsori's 246

17 Looby 326

20 I Loon $\quad 378,380$

14 Lord

11

M

13 Marlin

18 Marlin, Ring-tailed

14 Marsh-Hen, Fresh Water

3 " Salt Water

21 Martin, Purple

17 Maryland Yellow-throat

7 Meadow-Hen

3 Merganser, Buff-breasted

6 " Hooded 341

19 "

16 Mocking-bird, Gray 82

13 Mother Cary's Chicken 370, 372, 373

142 Mud-Hen

200

144 Myrtle-bird

55

342

N

2) Night Hawk

32

195 Night Jar

32

168

166

279 " White-bellied

282

2\% 6

284 Oriole, Baltinore

142

281 " Orchard 144

283 Ortolan

280 Osprey

$18 \mathrm{I}$ Ovan-hird

169. Owl, Acadian 


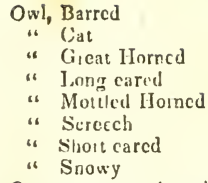

Oyster-zatcher, American

Partridge, American

Partridge

Petrel, Fork-tailed " J,east

“Whl:ori's

Phalarop,c, llyperborcan

$$
\text { “ Wed }
$$

Phcasant

Phœbe-tird

Pilcstart

Pipu, Ancrican

Pigeon, Common Wild

Ploser, Bealle-licaded

“ Black bellicd

"Bull-headed

" Field

" Gulden, Amcrican

“ Grass

" Gray

" Jlighland

6. Kldecr

" Jible

" Piping

" Ring, Amcrican

" Siviss

" Upland

"Wilson's

Pokc, Little

Pulie

Pulie, IVhito

Prdiric-Het

Prethen, Arctic

“ Cuncreus

Qua bird

Quack or Quawk

Quail

Jiail, Carolina

$$
\begin{aligned}
& \text { " Clapper } \\
& \text { " New Yosk } \\
& \text { "Rcd-breasted } \\
& \text { "Sora } \\
& \text { "Virginian } \\
& \text { Ycllow.brcastcd }
\end{aligned}
$$

24:Raren

27 Razur-oill

343

27 lied-t)ird, Black-tvinged

135

25 R.d Po.I J Jesser

2s Recd-hird

28 lice-bird

26 Ring-neck

22 liubur, Go'den

222 " Ground

* Jicd breasted

187

"Snamp

191

372 Sandpiper, Ash colored

373 ". Bartram's

370 " Bullibreasted

248 " Curlew

245

246

191

42

310

94

184

$2 ! 1$

211

211

226

213 Sap-sucl:cr

226 Stw-!nll

226 Sca Dove, Common

211 Sea Par:o:

218 slicarwater, Dusky

230 " Matlis

217 "Waudering

215 Shclldrake, Picd

211 "S'uamp

226 slrikic, Great Arerican

216 Skimncr, Black

287 Strakc lirr!

284 Sulinc, Black-brcast

283 " Blind

195) "Biorn-lrack

$3 i 3$ " Horscfoot

356 " Jack

"Meadow

279 " Ox.cye

279 " Qua!

187 " Red-breasted

liubin

201 “ Robin, White

206: "Sand

204 " Scmipalmated

209 "Short.ncck

201 "Willes

2118 "Wilson's

204 "Yellow-shanks
116

137

137

215

142

124.

86

124

224

226

230

237

232

233

236

228

$2: 4$

243

$24 !$

239

256

257

$\approx 40$

177

$339,341,342$

375

373,374

370

369

368

341, 342

339

155

346

41

223

261

263

2211

233

233

239,240

263

263

224

221

239, 240,243

$2: 4$

233

251

$26 \mathrm{I}$

250 
Snipe, Yellow-shanks, Greater

Sruow-bird, Cummon

$$
\text { "White }
$$

Sparrow, Chipping

" Ficls

" Savannah

" Sivamp

"Trce

“ Yellow-winged

Starling, Crescent Mcadow

" Red-winged

Stilt, Black-necked

Swan, American

Swallow, Bank

$$
\begin{array}{ll}
\text { " } & \text { Barn } \\
\text { " } & \text { Climmey } \\
& \text { Cliff }
\end{array}
$$

White-bellied

Siurf Bird

Swift, American

$$
\begin{array}{cl}
\text { Tailer, } & \text { Semipalmated } \\
\text { " } & \text { Solitary } \\
\text { " Spotted } & \text { Tell-tale } \\
\text { " } & \text { Wood } \\
\text { " } & \text { Yellow-shanks }
\end{array}
$$

Tanager, Scarlet

Teal, Blue-winged

" Green-winged

" Salt-water

Teru, Black

$\begin{array}{ll}\text { " Cayenue } \\ \text { " } \\ \text { " } & \text { Least } \\ \text { " } & \text { Mirsh } \\ \text { " } & \text { Roseate } \\ \text { " Trudeau' }\end{array}$

Thrush, Black-capped

" Ferruginous

"G Gilden-crowned

" Hermit

" Olive-backed

" Red-breasted

" Tawney

"Water

“ Wilson's

" Wood

Tiltup

Titmouse, Black-capped

$$
\text { " Crested }
$$

Tree-peck

Turnstcne

$$
\begin{array}{cl}
\text { Vireo, Red-eyed } \\
\text { " } \\
\text { " Solitary } \\
\text { " Warbling } \\
\text { " White-eyed } \\
\text { Ycllow-tlıroated }
\end{array}
$$

252 Vulture, Turkey Vulture or Buzzard 1

108 W

97 Warbler, Creeping, Black and white 70

Ic6 Warbler, Ground, Maryland 64

105 "“ Mourning 65

112. Warbler, Flycatching, Canadian 49

114 Hooded 47

107 " 4 Kentucky 49

"Wilson's 51

147 Warbler, Swamp,

141 Blue-winged yellow 66

2\%0 " " Golder-winged 68

298 “ “ Nashville 69

37 " Worm-eating 67

35 Warbler, Wocd,

33 " "Bay-breasted 62

38 " Blackburnian 53

36 “ Black-poll

36 “ Black-tlroated Blue 56

243 " Black-thrcated Green $\quad 57$

33 “ Blue-headed yellow-rumped 54

254 " Bluo Yellow-backed 60

$\tilde{254}$ “ Cape May ‘61

250 " “ Chestnut-sided 63

257 " Pine-creeping 51

252 “ Prairie 52

256 “ "

250 " “ Yellow-poll 258

135 " Yellow Red-poll 59

315 Water Pheasant 341

314 Water Pheasant

326 Wake-up, 165

352 Waxwing, Black-throated 163

347 Weaser 339

350 Whippoorwill 31

353 Widgeon $\quad 306,307$

351 Woodcock, American 266

354 Woodpecker, Canadian $\quad 176$

84 " " Downy 177

85 " 8 English 181

92 "G Golden-winged 181

90 " “ Hairy 174

91 " 6 Rod-bellied 179

86 “ Red-headed 180

89 " " Spotted 176, 177, 174

93 " $\quad$ Yellow-bellied 178

8? Wocd-Wagtail, Aquatic 93

\begin{tabular}{r|rr}
88 & " & Gollow-bird, Common-crowned \\
257 & Gellow-bren & 117
\end{tabular}

77 "

78 " " Summer 58

166,168 Yellow-tail $\quad 163$

220 Wren, Carolina $\quad 75$

\begin{tabular}{l|lll} 
& " & Golden-crowned & 80 \\
157 & " & Honse & 73 \\
160 & " & Marsh & 76 \\
161 & " & Ruby-crowned & 79 \\
158 & " & Winter & 72 \\
159 & " & Wood & $\mathbf{7 4}$
\end{tabular}








$$
\text { - }
$$







